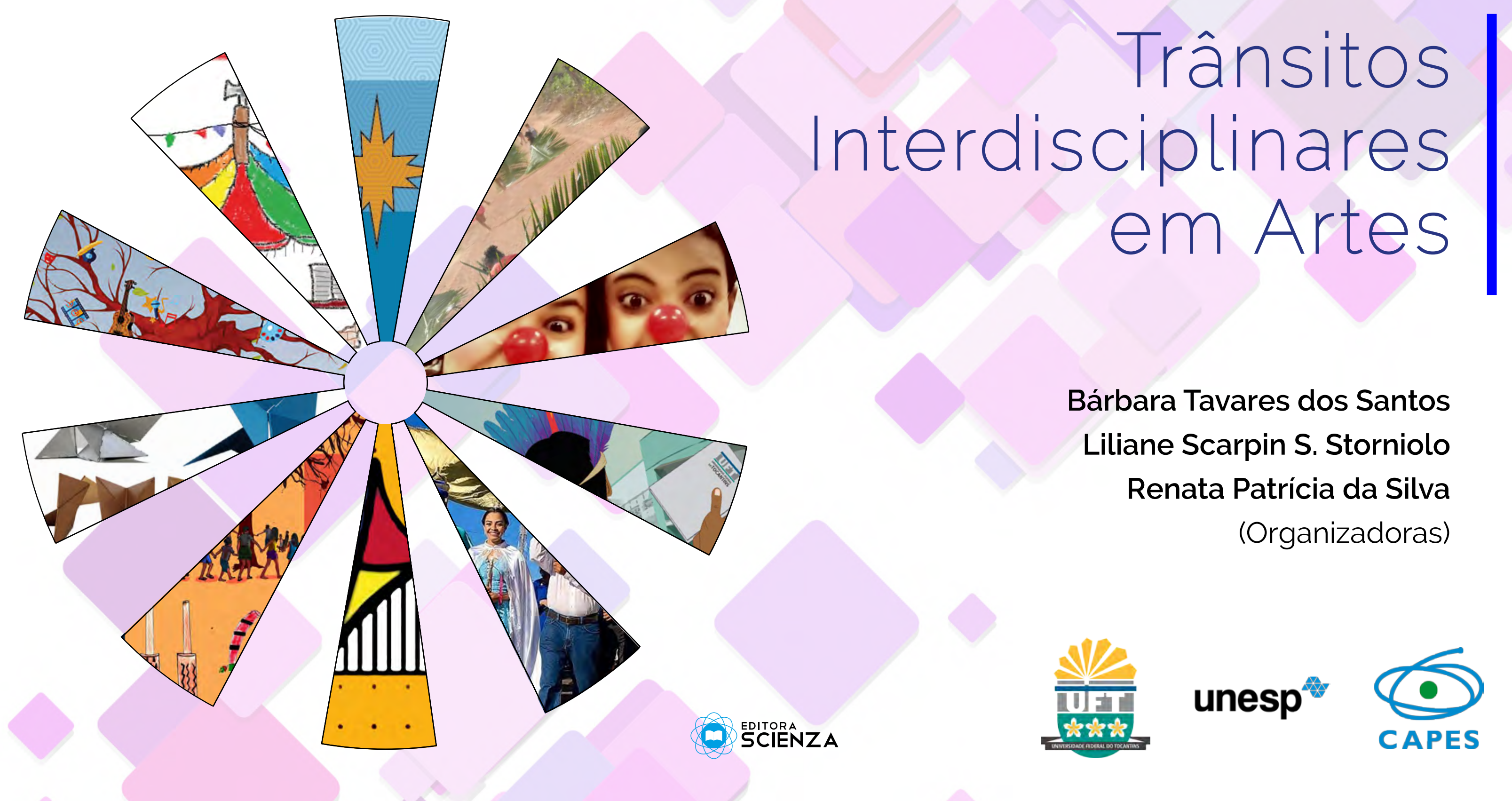


Comissão editorial

Sa596t Santos, Bárbara Tavares: Storniolo, Liliane Scarpin da Silva; Silva, Renata Patrícia (Orgs.)

Trânsitos Interdisciplinares em Artes / Bárbara Tavares dos Santos, Liliane Scarpin da Silva Storniolo, Renata Patricia da Silva, Organizadoras - São Carlos, 2021.

$239 \mathrm{p}$.

ISBN - 978-65-5668-027-9

DOI - http://dx.doi.org/10.26626/978-65-5668-027-9.2021B0001

1. Artes. 2. Política educacional. 3. Cultura. 4. Arte-educação. I. Org. II. Título.

CDD 690

Prof. Dr. Luciano Flávio de Oliveira http://lattes.cnpq.br/0084587484397779

Profa. Dra. Pritama Morgado Brussolo http://lattes.cnpq.br/1055582106065260

Profa. Ms. Jaqueline Vansan http://lattes.cnpq.br/0894824514569829

Profa. Ms. Kamila Gonçalves http://lattes.cnpq.br/6454079411511121

Revisão, Editoração, E-book e Impressão:

\section{C2 SDITORA}

Rua Juca Sabino, 21 - São Carlos, SP - (16) 9 9285-3689 www.editorascienza.com.br | gustavo@editorascienza.com 


\section{Sumário}

Apresentação

Currículo de Arte na Educação em Tempo Integral de uma Escola de Palmas - TO

Adriana dos Reis Martins, João Cardoso Palma Filho

Manifesto pela Arte na Educação Nacional

Rosemeri Birck, Roberto Francisco de Carvalho, João Cardoso Palma Filho

Wamhã Kãtô Kri Isanãmze Wakõmẽkwa Wamhã: Ensaios de Uma Prática Intercultural e Pós-Colonial no Ensino das Artes.

Raquel Castilho Souza, Karylleila dos Santos Andrade

Fragmentos Históricos da Formação Brasileira: Uma História de Etnocídio e Extermínio dos Povos Indígenas

Silvia Regina da Silva Costa, Carminda Mendes André

\section{Trânsitos Interdisciplinares em Artes}

Bárbara Tavares dos Santos, Liliane Scarpin, Renata Patrícia da Silva (Organizadoras) 
Habitações Lúdicas: O Fazer Teatral com as Crianças do Povoado Itaúba - TO

Renata Patricia da Silva, Carminda Mendes André

Tessituras de Experiências Cênico-Pedagógicas sobre a Docência da Encenação no Ensino Superior

Bárbara Tavares dos Santos

A Festa de Nossa Senhora do Rosário em Monte do Carmo - TO

Marinalva do Rego Barros Silva, Kátia Maia Flores

Riso, Fé e Cultura Popular na Boa Vista do Padre João.

Leandro Ferraz

Tradição nas Terras Tocantinenses: O Mito Fundador

Liliane Scarpin S. Storniolo, Karylleila Andrade Klinger

A Criação Artística em Camus: Estética e Poética Absurdas.

José Soares das Chagas, Alessandro Rodrigues Pimenta, Maria José de Pinho

\section{Trânsitos Interdisciplinares em Artes}

Bárbara Tavares dos Santos, Liliane Scarpin, Renata Patricia da Silva (Organizadoras) 


\section{Apresentação}

O livro Trânsitos Interdisciplinares em Artes, organizado pelas Professoras Doutoras Renata Patricia da Silva, Bárbara Tavares dos Santos e Liliane Scarpin, é resultado de pesquisas realizadas no Programa de Doutorado Interinstitucional em Artes Dinter/UNESP/UFT. Trata-se de uma produção acadêmica advinda das discussões provenientes de estudos e pesquisas realizadas no processo de elaboração de teses de Doutorado em Artes no âmbito do mencionado Programa, que é fruto de parceria entre as Universidade Estadual Paulista Júlio de Mesquista Filho (UNESP) e a Universidade Federal do Tocantins (UFT).

O processo educativo em pauta formou dez alunos/as em nivel de Pós-graduação stricto sensu (Doutorado) em Artes com ênfase em Artes Cênicas e Arte-Educação. Seguindo as diretrizes da Coordenação de Aperfeiçoamento de Pessoal de Nivel Superior (CAPES), com a formação dos mencionados doutores/doutoras, o curso buscou: contribuir para o desenvolvimento da pós-graduação em âmbito nacional; potencializar a formação de grupos de estudo e pesquisa e favorecer a formação de novos cursos de pós-graduação na UFT; estimular a criação de linhas de pesquisas que se enquadrem na realidade local em que a UFT se insere e atua; incentivar a participação de bolsistas de Iniciação Científica com vistas ao surgimento de novas vocações para a pesquisa; e promover a publicização dos resultados de pesquisas por meio de eventos e publicações.

\section{Trânsitos Interdisciplinares em Artes}

Bárbara Tavares dos Santos, Liliane Scarpin, Renata Patrícia da Silva (Organizadoras) 
Como parte integrante dos estudos acima mencionados, a presente obra reúne dez textos que abordam, com significativo aprofundamento, aspectos relacionados à Arte e Arte-Educação abrangendo a cultura, política educacional, currículo, formação de professores, fundamentos e práticas da educação escolar e não escolar, com forte inserção na educação, em geral, e na educação escolar tocantinense.

O livro aborda, inicialmente, o "Currículo de Arte na educação em tempo integral de uma escola de Palmas - TO". Neste texto, Adriana dos Reis Martins e João Cardoso Palma Filho buscam explorar os aspectos do ensino da Arte realizado na escola de tempo integral e a concepção de curriculo, em geral e currículo de Arte, em particular. Discute o curriculo de Arte desenvolvido nas escolas de tempo integral de Palmas buscando evidenciar qual a teoria que o fundamenta, bem como a relação existente entre a concepção/finalidade e estrutura curricular na perspectiva da Educação de Tempo Integral.
O texto dois trata do "Manifesto pela Arte na educação nacional". Nele, Rosemeri Birck, Roberto Francisco de Carvalho e João Cardoso Palma Filho defendem o ensino da arte como condição de humanização. Os autores fazem uma retrospectiva dos projetos educacionais apresentados na história, perpassando a concepção de Arte que priorizava o desenho e as lutas dos arteeducadores e que resultaram no reconhecimento da Arte como área do conhecimento obrigatório na composição curricular da educação escolar. Embora desvelando que o ensino de Arte na perspectiva da humanização na educação escolar brasileira vem sendo subsumido por uma lógica instrumentalizadora, concluem com a expectativa de que a problematização dos caminhos históricos da Arte e do ensino da Arte na educação brasileira incluindo a política curricular e a formação de professores - pode contribuir para uma formação emancipadora.

No terceiro texto, intitulado: "Wamhã kãtô kri isanãmze wakõmẽkwa wamhãı: ensaios de uma prática intercultural e pós-

\section{Trânsitos Interdisciplinares em Artes}

Bárbara Tavares dos Santos, Liliane Scarpin, Renata Patricia da Silva (Organizadoras) 
colonial no ensino das artes", as autoras Raquel Castilho Souza e Karylleila dos Santos Andrade adentram a uma das realidades educacionais do Tocantins e refletem sobre a política educacional para a educação indigena no mencionado estado, bem como sobre a prática intercultural e pós-colonial no ensino das artes na Escola Estadual Indigena Wakõmẽkwa. O texto revela um diagnóstico que apresenta vários entraves em relação à política/gestão e prática educativa para a realização efetiva da educação indígena no Tocantins e aponta caminhos didático-pedagógicos para o enfrentamento das adversidades. Nessa direção, indica o Ensino das Artes, como expressão da cultura Akwẽ, na "(re) invenção da escola indigena para uma prática intercultural pós-colonial na Escola Estadual Indigena Wakõmẽkwa".

O quarto texto discute os "fragmentos históricos da formação brasileira: uma história de etnocídio e extermínio dos povos indigenas". As autoras Silvia Regina da Silva Costa e Carminda Mendes André abordam a temática do etnocídio e extermínio dos povos indigenas situada no contexto histórico brasileiro e explicitam, com base na legislação, as políticas indigenistas e elaboradas nos periodos que vão do Brasil Colônia à Nova República. As autoras concluem, a partir das reflexões presentes no texto, que a legislação analisada, em grande medida, foi contrária aos direitos dos povos indígenas e contribuiu para a exploração e morte de uma parte significativa dessa população.

No quinto texto, intitulado: "Habitações lúdicas: o fazer teatral com as crianças do povoado Itaúba - TO" Renata Patrícia da Silva e Carminda Mendes André relatam a experiência relacionada à investigação do teatro da escola, partindo da compreensão de uma docência como ação tática. A perspectiva de docência, explicitada na mencionada experiência caracteriza-se pela inquietude, pois não se fixa em um espaço circunscrito à sala de aula tradicional, tendo em vista que o local da realização do processo educativo espraia-se por espaços variados e ocorre de múltiplas formas. Nessa linha de raciocínio, para além do corriqueiro

\section{Trânsitos Interdisciplinares em Artes}

Bárbara Tavares dos Santos, Liliane Scarpin, Renata Patrícia da Silva (Organizadoras) 
controle e disciplina dos corpos, o teatro na escola é fundamental para explorar o território escolar como local em que se inscrevem diferentes saberes-fazeres formativos.

Bárbara Tavares dos Santos trata, no sexto artigo, das "Tessituras de experiências cênico-pedagógicas sobre a docência da encenação no ensino superior" e toma como objeto as experiências cênicas da pesquisadora no curso de Licenciatura em Teatro da UFT. Na experiência didático-pedagógica apresentada a autora coteja variadas poéticas relativas à Pedagogia da Encenação desenvolvidas no Curso de Licenciatura em Teatro por meio de estratégias e táticas estéticas adotadas no processo de criação cênica, em perspectiva coletiva. Em uma abordagem crítica, a pesquisadora expõe, portanto, uma prática educativa construida coletivamente, que articula as experiências da vida pregressa e a vivência em tempo presente, sem perder de vista as expectativas formativas em relação ao futuro.

Com foco na cultura popular e na tradição, o artigo sétimo, intitulado: "A festa de Nossa Senhora do Rosário em
Monte do Carmo - TO", de Marinalva do Rego Barros Silva e

Kátia Maia Flores, relata o planejamento, realização, avaliação e replanejamento da Festividade de Nossa Senhora do Rosário, acontecimento histórico fundamental realizado na comunidade de Monte do Carmo - TO. O estudo explicita que o evento investigado tem um profundo sentido para os participantes e abrange a vida em ação, incluindo, entre outros aspectos: o sentimento de pertencimento e participação comunitária; o poder de decisão dos participantes da comunidade no processo de planejamento e realização da festa; a adesão voluntária dos sujeitos sociais; a inclusão de todos que queiram participar; e, principalmente, a preservação da tradição.

Seguindo a trilha da investigação cultural, o oitavo texto, de Leandro Ferraz, denominado: "Riso, fé e cultura popular na Boa Vista do Padre João" toma como ponto de partida para a reflexão a temática relacionada ao Ridículo entre o Sagrado e o Profano. Partindo desse pano de fundo amplo, o autor busca compreender o que permeia a cultura popular, o riso e a fé e conclui que "[...] o

\section{Trânsitos Interdisciplinares em Artes}

Bárbara Tavares dos Santos, Liliane Scarpin, Renata Patrícia da Silva (Organizadoras) 
ridiculo torna-se um meio de acalento com papel pacificador entre o sagrado e o profano quando ele deixa de ser somente profano e de ser somente sacro e se torna apenas o ridículo, lugar onde não há estranhamentos e o riso é livre e leve".

Sob o título: "Tradição nas terras tocantinenses: o mito fundador", das autoras Liliane Scarpin S. Storniolo e Karylleila

Andrade Klinger, o nono texto aborda o debate acerca do mito fundador do estado do Tocantins como base para o estudo da cultura tocantinense, com foco específico nas composições musicais desenvolvidas no estado após a sua criação, em 1988. No texto em pauta - que abrange aspectos históricos, políticos, econômicos e culturais do estado -, o leitor encontra a reflexão sobre a história da criação do Tocantins, tendo como ponto de partida o mito fundador, segundo o qual a história do povo tocantinense confunde-se "com a história de vida de Wilson Siqueira Campos", primeiro governador do estado.

O décimo e último texto: "A criação artística em Camus: estética e poética absurdas", de autoria de José Soares das
Chagas, reflete sobre a estética e a poética absurdas a partir da obra literária e filosófica do argelino Albert Camus. Por meio da incursão filosófica o pesquisador analisa como a arte, em geral. e os romances, em particular, traduzem e manifestam o conceito de estética do homem moderno frente às absurdas experiências do cotidiano tensionado pelo desejo racional e explicador da vida. O autor infere do pensamento de Camus que a Arte, em geral, "obedece à regra do absurdo na medida em que o artista, movido por sua intuição e imaginação, coloca-se um problema que, ao final, ele se nega a responder". Em outras palavras, trata-se de poética e estética absurdas que expressam um movimento no qual há a tensão entre o transcendente e o existente, a razão e a experiência.

Em uma perspectiva interdisciplinar e articulando temáticas diversificadas, o livro aqui apresentado se propõe, portanto, a promover o debate convergente ao campo da Arte. Embora reúna temáticas variadas, a obra possui um eixo articulador relacionado à formação humana e, em seu bojo - em sentido lato - à formação de educadores, isto é, daqueles que lidam, cotidianamente, no

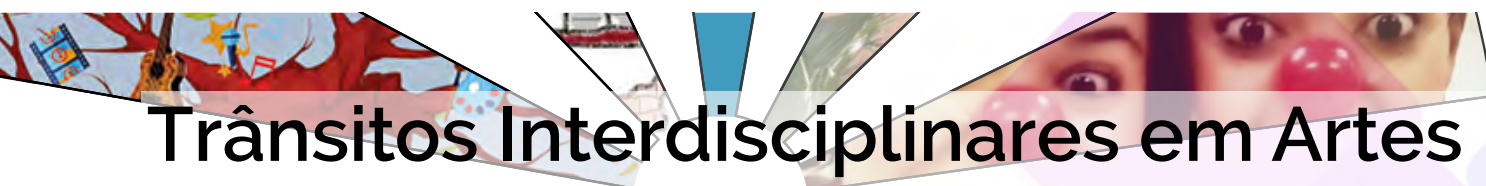


- $\bullet \quad \bullet$

-
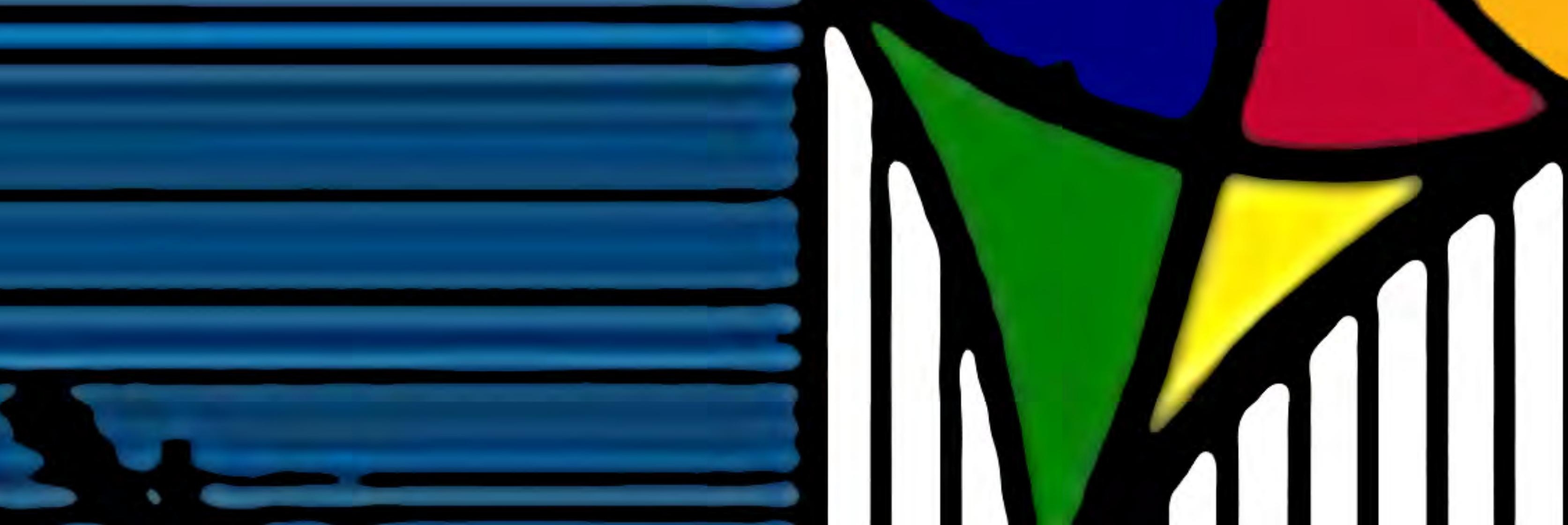


\section{Currículo de Arte na Educação em Tempo Integral de uma Escola de Palmas - TO}

Adriana dos Reis Martins ${ }^{1}$ João Cardoso Palma Filho

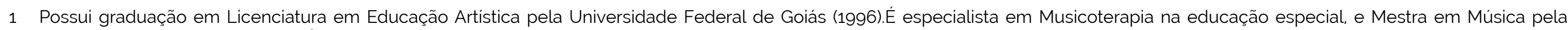

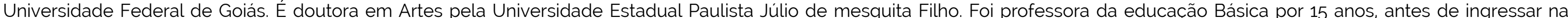

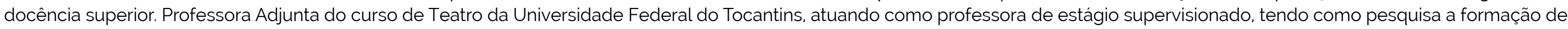
professores para educação básica e currículo de arte. E-mail: adrianaarte@uft.edu.br - https://orcid.org/0000-0002-2021-3500.

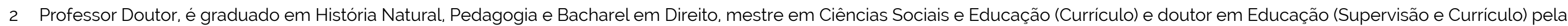

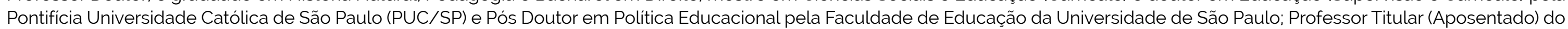

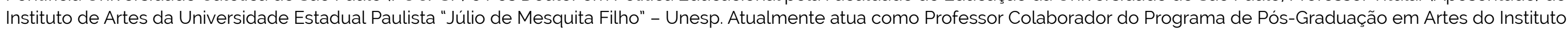
de Artes da Unesp.

\section{Trânsitos Interdisciplinares em Artes}

Bárbara Tavares dos Santos, Liliane Scarpin, Renata Patricia da Silva (Organizadoras) 
artigo aqui apresentado surge de um recorte do estudo realizado a respeito do currículo de Arte desenvolvido nas escolas de tempo integral de Palmas, cenário deste estudo, que teve como proposta investigar qual é a teoria utilizada para sua construção e qual a participação dos professores.

Este texto foi elaborado a partir de um recorte da tese de doutorado da autora, que de 2016 a 2019 realizou estudos e pesquisa na área do currículo de Arte, para evidenciar qual a teoria que fundamenta esse currículo, bem como a relação existente entre tal estrutura curricular, a concepção de suas finalidades na perspectiva da Educação de Tempo Integral.

A pesquisa fundamentou-se nos principios da abordagem qualitativa, utilizando-se do estudo de caso para a investigação e a análise qualitativa crítica como técnica de organização e compreensão das entrevistas. A coleta de dados foi feita por meio de entrevistas semiestruturadas desenvolvidas com professores de Arte em uma Escola de Tempo Integral de Palmas/TO. A discussão sobre o objeto de investigação referendou-se na produção teórica do campo do currículo, na educação integral em tempo integral, na legislação educacional e no Ensino da Arte, associado ao corpus empírico da pesquisa, na perspectiva da Teoria Crítica, da Escola de Frankfurt. As referências teóricas basearam-se em Cavalieri (2010), Coelho (2009), Saviani (2007), Romanelli (2007). Palma Filho (2005), Coutinho (2011), boletins da Federação dos Arte-Educadores (FAEB) e documentos oficiais, como a Base Nacional Comum Curricular (BNCC, 2018), Lei de Diretrizes e Base (1996), Silva (2015), Apple (2006), Giroux (1986) e Sacristán (2013)

No texto apresentado, buscou explorar aspectos do ensino da Arte realizado na escola de tempo integral, e a concepção de currículo e currículo de arte.

\section{Trânsitos Interdisciplinares em Artes}

Bárbara Tavares dos Santos, Liliane Scarpin, Renata Patricia da Silva (Organizadoras) 


\section{Caminhos Metodológicos Percorridos}

Como procedimento metodológico, foi realizado um estudo bibliográfico e de campo, buscando compreender e refletir sobre a importância do Ensino da Arte no processo de formação do individuo. Em um primeiro momento, compreende-se que concepções teóricas de abordagens, teoria e a metodologia caminham juntas. Entendo que é necessário seguir certos parâmetros para realizar um trabalho de pesquisa significativo.

Para a compreensão dos questionamentos da pesquisa, foi utilizada a Teoria Crítica, sabendo que as teorias são explicações da realidade que buscam esclarecer melhor o objeto de investigação. Por permitir uma maior clareza na organização dos dados é que se fez a escolha pela Teoria Crítica que, na compreensão de autores como Apple (2006), Giroux (1986) e Silva (2007), advêm da própria realidade. Com essa teoria, foi possivel desenvolver um discurso sistemático que orientou o olhar sobre o problema, bem como a coleta e a análise dos dados.
A Teoria Crítica é decorrente da perspectiva marxista. o pensamento expresso por essa teoria foi sistematizado pelos teóricos da escola de Frankfurt: Jürgen Habermas. Herbert Marcuse, Max Hokheimer e Theodor Adorno, com o propósito de "[...] repensar e reconstruir o significado de emancipação humana" (GIROUX, 1986, p. 21).

De acordo com Giroux (1986), para entender a Teoria Crítica, é preciso compreender as relações entre o particular e o todo, e entre o específico e o universal. Assim, esse posicionamento diferencia-se totalmente da perspectiva positivista, na qual a teoria é uma questão de ordenar e classificar os fatos. Ao rejeitar a ideia de considerar os fatos de forma absoluta, a escola de Frankfurt argumenta que, na relação entre teoria e sociedade, existem mediações que dão significado à natureza que constituem os fatos, a natureza e a substância do discurso teórico. Para o autor, pensamento dialético refere-se à crítica e à reconstrução teórica. Como modo de crítica, revela valores que são, muitas vezes, negados quando se analisa determinado objeto

\section{Trânsitos Interdisciplinares em Artes}

Bárbara Tavares dos Santos, Liliane Scarpin, Renata Patricia da Silva (Organizadoras) 
social. Nesse sentido, a noção de dialética é importante porque revela a incompletude, o que é, em termos do que não é, e das potencialidades ainda não realizadas.

Entende-se que a Teoria Crítica ${ }^{3}$ é importante como abordagem teórica para a pesquisa qualitativa em Ciências Humanas e Sociais e para a análise de questões contemporâneas da sociedade. Além disso, trata-se de um novo modo de observar e de refletir a realidade, e o agir humano da nossa sociedade. Tal vertente teórica, portanto, constitui-se como um método em potencial para o desenvolvimento de pesquisas em várias áreas do conhecimento, dentre elas a área da Educação.

Partindo do objetivo descrito anteriormente, a pesquisa apresenta características de uma investigação qualitativa e constitui-se em um estudo de caso. Segundo Minayo (2014), a

3 Na perspectiva dos estudiosos da "Escola de Frankfurt", deve-se a Max Horkheimer o primeiro esboço do que seria a Teoria Crítica. pesquisa qualitativa responde a questões particulares, enfoca um nivel de realidade que não pode ser quantificado e trabalha com um universo de múltiplos significados, motivos, aspirações, crenças, valores e atitudes. A autora defende que qualquer investigação social deveria contemplar uma característica básica de seu objeto, que é o aspecto qualitativo.

A pesquisa qualitativa apresenta-se a partir da obtenção de dados descritivos, coletados diretamente com as situações estudadas, enfatizando as formas de manifestação, os procedimentos e as interações. Minayo (2014, p. 57) afirma que "as abordagens qualitativas se conformam melhor à investigação de grupos e segmentos delimitados e focalizados, de histórias sociais sob a ótica dos atores, de relações e para análises de discursos e de documentos". A pesquisa qualitativa lida com interpretações das realidades sociais. O protótipo mais conhecido é, provavelmente, a entrevista em profundidade.

\section{Trânsitos Interdisciplinares em Artes}

Bárbara Tavares dos Santos, Liliane Scarpin, Renata Patricia da Silva (Organizadoras) 
Como abordagem metodológica, recorreu-se ao estudo de caso, que é um meio de organizar os dados preservando o caráter unitário do objeto estudado. O estudo de caso é "um dos empreendimentos mais desafiadores na pesquisa" (YIN, 2010, p. 23). Esse método constitui, atualmente, uma das principais modalidades de pesquisa qualitativa no campo das ciências humanas e sociais e teve seus procedimentos convencionados de forma adequada a partir da obra de Robert Yin, nos anos de 1990.

Nesse contexto, a coleta de dados da pesquisa obteve a duração de quatro meses antes do exame de qualificação do doutorado e foi desenvolvida em uma escola municipal de tempo integral, da cidade de Palmas. Após a qualificação, com os apontamentos realizados pelos professores avaliadores, senti a necessidade de voltar ao campo para continuar a pesquisa com ampliação da entrevista semiestruturada. Acrescentei pontos importantes para a conclusão da investigação, ficando mais quatro meses em contato com o campo de pesquisa.
A escolha da cidade de Palmas como campo de pesquisa ocorreu por ter, como política educacional, a educação de tempo integral. De acordo com Minayo (2014, p. 201), "[...] entendo por campo, na pesquisa qualitativa, o recorte espacial que diz respeito à abrangência, em termos empíricos, do recorte teórico correspondente ao objeto de investigação." Compreende-se que o trabalho de campo é fundamental para a pesquisa qualitativa, já que é fundamental a interação entre o pesquisador e os participantes da pesquisa.

Dentre os seis professores de Arte da escola, foram selecionados dois para participar da pesquisa, com base nos seguintes critérios: ter disponibilidade para participar da pesquisa; ser formado em área de Arte; ser formado em área diferente de Arte e atuar como professor de alguma disciplina de Artes. 0 terceiro critério foi usado por ter a complementação da carga horária em uma escola de tempo integral.

\section{Trânsitos Interdisciplinares em Artes}

Bárbara Tavares dos Santos, Liliane Scarpin, Renata Patricia da Silva (Organizadoras) 
O mapeamento realizado sobre a oferta das três linguagens artísticas foi fundamental para uma reflexão sobre a realidade do municipio de Palmas. Nota-se que ainda há carência de professores de todas as linguagens artísticas nas escolas municipais e estaduais e que a gestão das escolas tem interesse em ofertar todas as linguagens artísticas (MARTINS; CASTILHO; BODNAR, 2017, s./p.).

Como instrumento de pesquisa, utilizou-se a entrevista semiestruturada. De acordo com Minayo (2014, p.191), o roteiro para a entrevista semiestruturada "deve desdobrar os vários indicadores considerados essenciais e suficientes em tópicos que contemplam a abrangência das informações coletadas". Os roteiros de entrevistas foram elaborados e organizados a partir dos objetivos da pesquisa e do referencial teórico que deu suporte para esse estudo. As entrevistas semiestruturadas foram organizadas em torno das seguintes temáticas: 1) a Arte na legislação, a partir da obrigatoriedade desse ensino nos currículos escolares; 2) a diferença de educação integral e educação de tempo integral; 3) concepção de currículo; 4) currículo de Arte na ETI (Escola de Tempo Integral). Os roteiros serviram para estimular os sujeitos a dialogar sobre as questões levantadas pelo pesquisador no momento da entrevista. Cabe ressaltar que os roteiros foram elaborados considerando o perfil e a atuação dos participantes da pesquisa.

Com o propósito de compreender qual o currículo de Arte que o municipio de Palmas oferece para suas escolas de tempo integral e que currículo é realizado na escola, realizou-se pesquisa de campo, buscando no estudo de caso as respostas para a questão levantada neste trabalho. Como técnica, utilizou-se a entrevista semiestruturada, aplicada às duas professoras que ministram aulas de teatro e de artes visuais na escola de tempo integral.

Como estratégia metodológica, recorreu-se ao método da Teoria Crítica, sabendo que as teorias são explicações da realidade que buscam esclarecer melhor o objeto de investigação. Por permitir uma maior clareza na organização dos dados é que se fez a escolha pela Teoria Crítica, legitimando as argumentações teóricas em autores como Apple (2006) e Giroux (1986). Com a teoria aqui escolhida, foi

\section{Trânsitos Interdisciplinares em Artes}


possivel desenvolver um discurso sistemático que orientou nosso olhar sobre o problema, a coleta dos dados e sua análise.

Como a educação é uma prática social, que resulta de condicionantes políticos, econômicos, sociais e culturais, a abordagem crítica em pesquisas educacionais pressupõe uma concepção unitária, coerente e orgânica do mundo e faz da crítica seu modelo paradigmático, de tal modo que não basta tentar compreender a realidade, faz-se necessário intervir nela visando à emancipação dos sujeitos.

Dessa forma, a pesquisa apresenta características de uma investigação qualitativa e constitui-se em um estudo de caso. De acordo com Minayo (2014, p. 164), "os estudos de caso utilizam estratégias de investigação qualitativa para mapear, descrever e analisar o contexto, as relações e as percepções a respeito da situação, fenômeno ou episódio em questão".
A partir dos estudos e das discussões realizadas, notouse que para a análise de dados pela perspectiva da Teoria Crítica há categorias a serem aplicadas, além da práxis: o poder, a emancipação, a cultura, a ideologia e a justiça social. Acreditou-se que essas contribuíram para a compreensão dos dados. No entanto, cabe destacar que as categorias aqui abordadas não caracterizam a totalidade das que podem ser utilizadas em pesquisas realizadas pela perspectiva crítica.

Pretendeu-se, com a análise realizada, obter uma compreensão dos significados na fala dos participantes. relacionando contexto com a teoria utilizada, finalizando com uma redação que priorize a qualidade da pesquisa.

\section{Trânsitos Interdisciplinares em Artes}

Bárbara Tavares dos Santos, Liliane Scarpin, Renata Patricia da Silva (Organizadoras) 


\section{Percurso da Arte em Palmas}

Um dos questionamentos mais presentes nos debates que realizo a partir da realidade do Ensino de Arte na Educação Básica em Palmas, considerando as experiências dos professores da rede municipal de ensino, refere-se à coerência entre a presença da Arte na legislação sobre Educação Básica e o modo como o(s) currículo(s) dessa área é (são) pensado(s), construído(s) e desenvolvido(s) na escola.

Uma metáfora proposta por Sacristán (2013) tem me ajudado a pensar sobre essa dinâmica entre legislação, currículo enquanto documento e currículo em desenvolvimento. O autor compara o texto curricular (currículo oficial) com uma partitura musical, e o seu desenvolvimento como sendo a música executada. Ele afirma que "ambos guardam relação entre si, embora sejam coisas distintas. Com base na partitura, podem ser desenvolvidas ou executadas músicas diferentes" (SACRISTÁN, 2013, p. 25).
O atual modelo educacional para a Educação Básica implantado em Palmas começou a ser delineado em janeiro de 2005. quando foi criado o Grupo de Estudos em Políticas Públicas e Gestão da Educação, no âmbito da Secretaria Municipal de Educação. Tal grupo contava com a participação de profissionais de diversas áreas, como: educacional, construção civil, arquitetônica, ambiental, bem como membros do Conselho Municipal de Educação (ALVES, 2012; MARTINS, 2011: SOUSA, 2012). O objetivo desse grupo era, segundo Martins (2011, p. 34), o de "discutir, pensar e conceber uma proposta para a educação com tempos e espaços de aprendizagem diferenciados em relação ao que estava sendo realizado no momento".

Duas equipes foram formadas: uma arquitetônica - que ficou responsável pelo planejamento e construção do espaço fisico -, e uma equipe diretiva - cuja responsabilidade foi a de elaborar uma proposta de educação em tempo integral para Palmas, seu Projeto Político Pedagógico (PPP) e sua matriz

\section{Trânsitos Interdisciplinares em Artes}


curricular. Para o cumprimento desses objetivos, essas equipes visitaram outras cidades onde o ensino nessa modalidade já era realidade, tais como Rio de Janeiro e São Paulo, buscando um referencial para a construção da Proposta de Ensino Integral a ser desenvolvida em Palmas.

Considera-se a Escola de Tempo Integral (ETI) - turno e contraturno ou turno único - o sistema de ensino com jornada escolar de sete horas, no mínimo, durante todo o ano letivo, tempo esse no qual o estudante permanece na escola ou em atividades escolares em outros espaços educacionais (BRASIL, 2013). Arroyo (2012, p. 43) chama a atenção para o fato de que a ETI não se restringe à ampliação de tempo e de espaço, mas diz respeito à reorganização radical dos "tempos-espaços do viver a infânciaadolescência, tornando-os mais próximos de um digno e justo viver. ao menos na totalidade dos tempos-espaços escolares".

Com a proposta de uma ETI, o sistema de ensino no municipio de Palmas elaborou uma matriz curricular propondo a integração das oficinas artísticas ao currículo, observando-se duas questões centrais: a ideia de Arte como área de conhecimento humano, patrimônio histórico e cultural da humanidade e Arte como linguagem, portanto um sistema simbólico de representação, tendo os seguintes objetivos:

Propiciar aos alunos a criação de formas artísticas, representação de ideias, emoções e sensações por meios poéticos nas diferentes linguagens da arte e como representação de pensamentos e sentimentos; possibilitar ao aluno reconhecer-se como produtor nas linguagens artísticas Teatro, Dança, Artes Visuais ou Música mobilizando-o a ampliar seus conhecimentos em cada uma das linguagens; propiciar um intenso e sistematizado contato dos alunos com a leitura e produção de textos nas linguagens não verbais, matéria-prima do universo da arte; possibilitar aos alunos: manipular, organizar, compor. significar, decodificar, interpretar, produzir e conhecer imagens visuais, sonoras e gestuais/corporais, entre outros (PALMAS, 2007).

\section{Trânsitos Interdisciplinares em Artes}

Bárbara Tavares dos Santos, Liliane Scarpin, Renata Patricia da Silva (Organizadoras) 
Percebe-se que, na proposta de implantação da educação de tempo integral de Palmas, o Ensino da Arte é apresentado por meio de vivências curriculares que repercutem em um processo de pensar/construir/fazer, que inclui atos técnicos e inventivos de transformação e produção de formas a partir da matéria oferecida pela natureza e pela cultura em que vive o educando. A proposta de implantação apresenta a atuação docente como àquela que busca a articulação de maneira interdisciplinar e transdisciplinar, tendo em vista a interdependência entre as áreas do conhecimento.

Com essa proposta de ETI que o municipio apresenta. percebe-se a necessidade de verificar se esse municipio prescreveu um currículo de Arte que apresenta, em sua estrutura, o pensar/ construir/fazer. Ainda, segundo Soares (2012, p. 130), nas ETIs de Palmas, "o currículo precisa ser modelado pela diversidade cultural dos professores/educadores em contato com a heterogeneidade cultural dos alunos".

Nessa proposta, o formato é a escola de jornada integral, que funciona em tempo integral, em que o aluno pode ficar na escola por 9 (nove) horas. Sua matriz contempla as quatro linguagens artísticas (artes visuais, dança, música e teatro). Cabe ressaltar que há dois modelos de escola no ensino municipal de Palmas. O primeiro refere-se à escola de jornada parcial, que funciona 4 (quatro) horas de ensino em cada turno (matutino e vespertino), com uma matriz com menos disciplinas. Nesse formato de escola, é desenvolvida a arte visual, como complementação de carga horária de teatro, sendo que os alunos têm uma aula por semana de cada linguagem. Alguns professores possuem formação na linguagem em que ministram as aulas; em outros casos, há uma complementação de carga horária do professor de outra área de conhecimento, que ocorre com a

\section{Trânsitos Interdisciplinares em Artes}

Bárbara Tavares dos Santos, Liliane Scarpin, Renata Patricia da Silva (Organizadoras) 
justificativa de que não há professor com formação específica das linguagens artísticas na rede de ensino.

Atualmente, a Rede Municipal de Ensino de Palmas é constituida por 31 (trinte e um) Centros Municipais de Educação Infantil (CMEls) e 44 (quarenta e quatro) escolas, conforme Relação das Escolas Municipais - Palmas/TO - Ensino Fundamental. O sistema de ensino do município conta com 27 (vinte e sete) escolas com jornada parcial e 17 (dezessete) escolas com jornada de tempo integral, sendo que as escolas de tempo integral se dividem em duas categorias: escola de tempo integral da zona urbana e escola de tempo integral da zona rural. O municipio tem o seguinte formato de ensino, segundo Alves (2013):

Os Centros Municipais de Educação Infantil (CMEls) compõem a segunda modalidade de educação integral, priorizando a oferta de educação infantil, com atendimento às crianças de 4 meses a 3 anos e 11 meses em tempo integral, em uma jornada de 10 horas diárias.
Escola de Tempo Integral do Campo constitui a terceira modalidade de educação integral na Rede Municipal de Ensino. A proposta de educação do campo neste município começou a ser pautada, a partir de abril de 2005. pela criação do Setorial de Educação do Campo e do Grupo de Estudos da Educação do Campo (2006).

Escola de Tempo Integral de Jornada Ampliada constitui a quarta modalidade de oferta de educação integral, iniciada em 2008 em três escolas da rede, que foram reformadas e adequadas, ampliando o tempo de permanência dos alunos para 8 horas diárias. Esta modalidade mantém semelhança com o Programa Mais Educação no que se refere à oferta de atividades artísticas, esportivas, cognitivas e culturais, no contraturno escolar.

A Escola Padrão de Tempo Integral é a quinta modalidade de educação integral. Atualmente são 03 unidades em funcionamento, atendendo, segundo dados do INEP (2011). a 3.481 alunos em 2011, em uma organização curricular de jornada diária de 9 horas e meia, por meio de um currículo formado por um núcleo comum, enriquecido por uma

\section{Trânsitos Interdisciplinares em Artes}

Bárbara Tavares dos Santos, Liliane Scarpin, Renata Patricia da Silva (Organizadoras) 
parte diversificada, oferecendo atividades no campo dos esportes e das artes (ALVES, 2013, p. 93).

Com a política de educação integral em tempo implantada em Palmas, houve construção de escolas para atender esse formato de ensino, e a entrega da primeira escola à comunidade ocorreu em 2007. Passados mais de 10 (dez) anos, há 17 (dezessete) escolas. Sabe-se que, para desenvolver a educação integral em tempo integral, é necessário mais do que a construção de espaço físico. Existe a necessidade de financiamento adequado, valorização do profissional da educação, um currículo que esteja atrelado à formação integral do aluno e materiais pedagógicos adequados.

\section{Pensando no Currículo sob a Perspectiva da Teoria Crítica}

O currículo, a partir da teoria crítica, pode possibilitar o desenvolvimento de conhecimentos que visam, não apenas a transmissão de saberes voltados para a reprodução de conteúdo, mas para a formação emancipatória dos alunos. Acredita-se que as teorias do currículo estão empenhadas em responder perguntas em relação ao conhecimento a ser ensinado aos alunos e ao tipo de ser humano desejável para a sociedade.

É importante considerar que ao curriculo corresponde tanto a uma questão de conhecimento quanto a uma questão de identidade. As teorizações críticas rejeitam o foco até então central nos processos de planejar, implementar e avaliar curriculos, voltando sua atenção para o conhecimento escolar e para os critérios implicados em sua seleção, distribuição, hierarquização, organização e transmissão nas escolas. Dessa forma, busquei entender, a quem pertence o conhecimento considerado válido de

\section{Trânsitos Interdisciplinares em Artes}

Bárbara Tavares dos Santos, Liliane Scarpin, Renata Patricia da Silva (Organizadoras) 
ser incluido no currículo de Arte, quem ganha e quem perde com as opções feitas. Procurei, ainda, compreender as resistências a todo esse processo, analisando de que modo seria possivel modificá-lo.

A reformulação ocorrida na Lei n 9.394/96, em 2010 , definiu que o Ensino da Arte, especialmente em suas expressões regionais, constituirá componente curricular obrigatório nos diversos niveis da Educação Básica. Essa lei foi batizada de "José Gomes Sobrinho", em homenagem a um dos pioneiros do Tocantins e considerado precursor do Ensino da Arte no Estado. Ele era defensor do estudo da cultura regional e teve seu sonho realizado pelo seu filho, o então deputado Eduardo Gomes (PSDB-TO), que afirmou:

Apesar de a arte e cultura serem universais, é fundamental que as raízes e as tradições regionais sejam respeitadas e difundidas em sala de aula. Isso reforça a ligação e a identidade do povo com sua própria cultura. Esse era o sonho de meu pai, que todos sabem foi um defensor nato da cultura regional (GOMES, 2010, s./p.).
A Lei "José Gomes Sobrinho" foi sancionada pelo então presidente da República Luiz Inácio Lula da Silva e passou a valer para todas as escolas do Brasil, já que alterou as diretrizes básicas da educação que constavam originalmente na Lei n 9.394/96. Como explica Gomes (2010, s/p.), "na prática, o estudante brasileiro terá condições de saber as origens do frevo, capoeira, folia de reis e do carnaval, entre outras manifestações culturais do Brasil". Os estudos culturais são de suma importância no âmbito educacional e os educadores em Arte devem compreender a importância deles para a formação do sujeito.

Nesta pesquisa, buscou-se refletir sobre as principais concepções de curriculo que permeiam a educação no municipio de Palmas, bem como verificar se sua proposta de currículo parte de uma perspectiva crítica. Assim, consideramos as contribuições no campo curricular dos teóricos Michael Apple e Henry Giroux para a fundamentação teórica dessa abordagem. Segundo Moreira (2007, p. 8), o currículo não se define como "[...] conteúdos prontos a serem passados aos alunos. É uma construção e seleção de

\section{Trânsitos Interdisciplinares em Artes}

Bárbara Tavares dos Santos, Liliane Scarpin, Renata Patricia da Silva (Organizadoras) 
conhecimentos e práticas produzidas em contextos concretos e em dinâmicas sociais, políticas e culturais, intelectuais e pedagógicas". Com esse direcionamento, nota-se a importância na elaboração de um currículo, sendo necessário entender, primeiramente, o local de criação desse documento.

Michael Apple e Henry Giroux são considerados os pioneiros da tendência curricular crítica e revelam a função ideológica do currículo. É a partir de suas concepções que as reflexões sobre o curriculo passam a serem compreendidas como as concepções de sujeito, educação e sociedade. De acordo com Apple (2006), o currículo se relaciona com os interesses sociais de um determinado contexto histórico. Ele deve ser baseado na dimensão científica, artística e filosófica do conhecimento.

Silva (2015) declara que os conceitos de uma teoria organizam e estruturam a forma de ver a realidade. O autor chama a atenção para as diferentes teorias do currículo e afirma que, para distingui-las, deve-se observar o que as mesmas empregam. Assim, quando a Teoria Crítica desloca a ênfase do seu conceito para ideologia e poder, ela está apresentando uma nova perspectiva de educação. A Teoria Crítica não trabalha com os conceitos simplesmente pedagógicos de ensino e aprendizagem; esses conceitos, por sua vez, são desenvolvidos nas teorias tradicionais de currículo.

Silva (2015, p. 17) comenta sobre as diferentes teorias do currículo e apresenta um quadro que resume as "grandes categorias de teoria de acordo com os conceitos que elas, respectivamente. enfatizam":

A existência de teorias sobre currículo está identificada com a emergência do campo do currículo como um campo profissional, especializado, de estudos e pesquisas sobre o currículo. As professoras e os professores de todas as épocas e lugares sempre estiveram envolvidos, de uma forma ou outra, com o currículo, antes mesmo que o surgimento de uma palavra especializada como "currículo" pudesse designar aquela parte de suas atividades que hoje conhecemos como "currículo" (SILVA, 2015, p. 21).

\section{Trânsitos Interdisciplinares em Artes}

Bárbara Tavares dos Santos, Liliane Scarpin, Renata Patricia da Silva (Organizadoras) 
Assim, percebe-se a necessidade de desenvolver pesquisas que buscam compreender a importância do currículo para o campo educacional. Com esse propósito esta pesquisa partiu dos principios de seleção e organização que são usados para planejar, ordenar e avaliar o conhecimento de uma determinada área e o modo como esses principios atuam como reprodução cultural e econômica das relações de classe em sociedade.

Ao concluir o trabalho de doutoramento, foi possivel afirmar que foram muitas as descobertas decorrentes da pesquisa, pois o Ensino de Arte sempre fez parte da minha jornada acadêmica e profissional. E, nos últimos anos, o seu espaço na escola de tempo integral tem me chamado a atenção, uma vez que essa escola contempla o ensino das quatro linguagens artísticas.

Os dados apontaram que o currículo de Arte, na perspectiva crítica, é dialético, emancipatório e inclusivo, partindo de uma prática restauradora, transgressora, intercultural e crítica, como um poderoso meio para reafirmar a singularidade na diversidade dos estudantes. A tese apresentada reafirma a concepção de que o currículo é um artefato sociocultural e histórico, portador de interesses, crenças e ideologias, capazes de formar identidades pessoais e sociais.

Na pesquisa realizada, o contato com a realidade escolar da ETI, com sua natureza, dimensões e expressões, possibilitoume compreender que essa realidade é uma fonte inesgotável de conhecimentos e que, por isso, muitos aspectos relacionados ao Ensino de Arte, bem como o currículo de Arte e sua vinculação com a ETI ainda podem ser explorados por novas pesquisas.

\section{Trânsitos Interdisciplinares em Artes}

Bárbara Tavares dos Santos, Liliane Scarpin, Renata Patricia da Silva (Organizadoras) 


\section{Referências Bibliográficas}

ALESSANDRA, K. Educação aprova dança e teatro como disciplinas obrigatórias do ensino básico. Câmara dos Deputados: Educação e Cultura. 2013. Disponivel em: http://www2.camara.leg.br/camaranoticias/noticias/ EDUCACAO-E-CULTURA/456284-EDUCACAO-PROVA-DANCA-E-TEATROCOMO-DISCIPLINAS-OBRIGATORIAS-DO-ENSINO-BASICO.html. Acesso em: 16 fev. 2017

ALVES, R. P. S. Os caminhos da educação integral em Palmas-Tocantins. Dissertação (Mestrado em Educação) - Programa de Pós-Graduação em Educação, Faculdade de Educação, Universidade Federal de Goiás, Goiânia, 2013. Disponivel em: https://repositorio.bc.ufg.br/tede/bitstream/tede. Acesso em: 12 jan. 2019.

ALVES, Z. M. B.; SILVA, M. H. G. F. D. Análise qualitativa de dados de entrevista: uma proposta. Paidéia, Ribeirão Preto, SP. n 2, p. 61-69, 1992. Disponivel em: http://dx.doi.org/10.1590/S0103-863X1992000200007. Acesso em: 5 maio 2018

APPLE, M. W. Ideologia e Currículo. 3. ed. Porto Alegre: Artmed, 2006
APPLE, M. W. A política do conhecimento oficial: faz sentido a ideia de um currículo nacional? In: MOREIRA, A. F.; TADEU, T. (Orgs.). Currículo, cultura e sociedade. 12. ed. São Paulo: Cortez, 2013.

ARROYO, M. G. Experiências de inovação educativa: o curriculo na prática da escola. In: MOREIRA, A. F. B. (Org.). Currículo: políticas educativas. 13. ed. Campinas: Papirus, 2011. p. 131-164.

ARROYO, M. G. O direito a tempos-espaços de um justo viver. In: MOLL, J. Caminhos da Educação Integral no Brasil: direito a outros tempos e espaços educativos. Porto Alegre: Penso, 2012. p. 33-44

GIROUX, H. Teoria Crítica e resistência em educação. Rio de Janeiro: Vozes, 1986

GIROUX, H. A.; SIMON, R. Cultura popular e pedagogia crítica: a vida cotidiana como base para o conhecimento curricular. In: MOREIRA, A. F.: TADEU, T. (Orgs.).

Currículo, cultura e sociedade. 12. ed. São Paulo: Cortez, 2013.

\section{Trânsitos Interdisciplinares em Artes}

Bárbara Tavares dos Santos, Liliane Scarpin, Renata Patricia da Silva (Organizadoras) 
MARTINS, A. R. O ensino de música na cidade de Palmas - TO após o advento da Lei 11.769/08. Dissertação (Mestrado em Música) - Escola de Música e Artes Cênicas, Universidade Federal de Goiás: Goiânia, 2011

MARTINS, A. R.; CASTILHO, R. S.; BODNAR, R. O ensino das artes em Palmas TO: complexidades e desafios em pesquisas. In: CONGRESSO NACIONAL DA FEDERAÇÃO DE ARTE/EDUCADORES DO BRASIL. 27., 2017. Campo Grande, MS. Anais... Federação de Arte/Educadores do Brasil, 2017. 3050 p. Disponivel em: https://faeb.com.br/admin/shared/midias/1510688060.pdf. Acesso em: 15 fev. 2018.

MINAYO, M. C. S. O desafio do conhecimento: pesquisa qualitativa em saúde. 14. ed. São Paulo: Hucitec, 2014.

SACRISTÁN. J. G. (Org.). Saberes e incertezas sobre o currículo. Porto Alegre: Penso, 2013
MOREIRA, A. F. B. Indagações sobre currículo: currículo, conhecimento e cultura. Brasília: MEC/SEB, 2007

SILVA, T. T. Documentos de identidade: uma introdução às teorias do currículo. 2. ed. Belo Horizonte: Autêntica, 2015

SOARES, P. S. G. Projeto Político Pedagógico e Currículo das Escolas de Tempo Integral de Palmas. In: ANDRADE, K. S. (Org.). Pesquisa e acompanhamento da universalização da educação integral: diagnóstico da educação integral do município de Palmas - TO. Goiânia: Ed. da PUC Goiás, 2012

SOUZA, D. M. A experiência em Palmas. In: MOLL, J. (Org.). Caminhos da Educação Integral no Brasil: direito a outros tempos e espaços educativos. Porto Alegre: Penso, 2012.

YIN. R. K. Estudo de caso: planejamento e métodos. 4. ed. Porto Alegre: Bookman, 2010.

\section{Trânsitos Interdisciplinares em Artes}

Bárbara Tavares dos Santos, Liliane Scarpin, Renata Patricia da Silva (Organizadoras) 


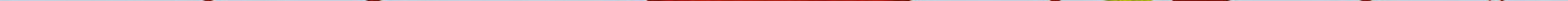




\section{Manifesto pela Arte na Educação Nacional}

Rosemeri Birck ${ }^{1}$

Roberto Francisco de Carvalho²

João Cardoso Palma Filho ${ }^{3}$

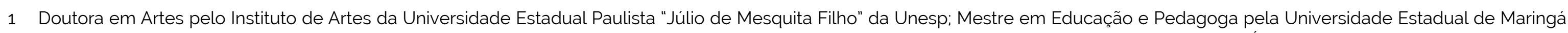

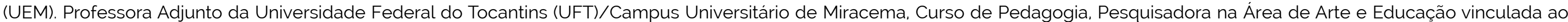

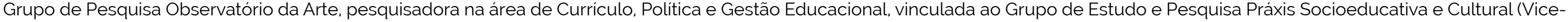
Lider). E-mail: rosebirck@uft.edu.br, https://orcid.org/0000-0002-2133-9316.

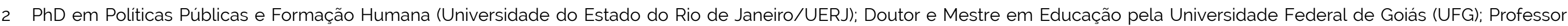

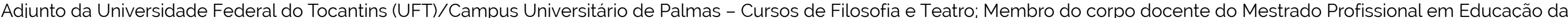

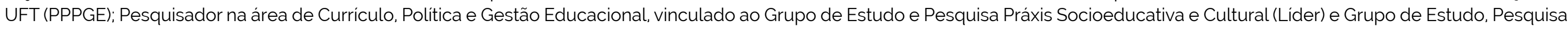

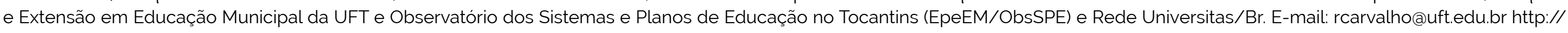
orcid.org/0000-0001-7278-181X

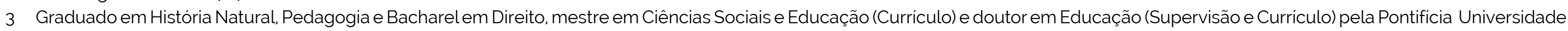

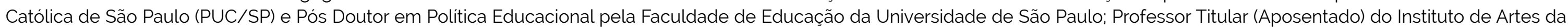

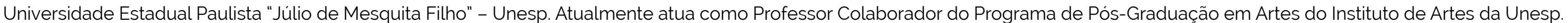

\section{Trânsitos Interdisciplinares em Artes}

Bárbara Tavares dos Santos, Liliane Scarpin S. Storniolo, Renata Patrícia da Silva (Organizadoras) 
Este texto é um recorte da pesquisa realizada na tese de doutorado no qual se faz a defesa do ensino da arte como condição de humanização. Aqui apresentamos uma retrospectiva dos projetos educacionais apresentados na história, perpassando a concepção de Arte que priorizava o Desenho e as lutas manifestadas pelos arte-educadores que resultaram no reconhecimento da Arte como área do conhecimento obrigatório na composição curricular na educação escolar.

Historicamente, observa-se que a Arte está presente no campo educacional brasileiro desde a presença dos padres Jesuitas no Brasil - de 1549 a $1759^{4}$ - durante o processo colonizador. Com interferência artística, no modelo de educação imposto para o ensino elementar, em especial aos povos originários, o teatro, a

4 Os primeiros Jesuitas chegaram ao Brasil em 1549 em companhia do primeiro governadorgeral Tomé de Sousa e em 1759 foram expulsos por Marques de Pombal. A cronologia da educação no período colonial jesuítico divide-se em: "Fase heroica: de 1549 a 1570 catequese. Fase de consolidação: de 1570 a 1759 - expansão do ensino secundário nos colégios" (ARANHA, 2006, p. 138). poesia e a produção de instrumentos musicais se constituiam em alguns dos recursos didáticos utilizados. Os Jesuitas seguiam a teoria da educação baseada nas concepções tradicionais religiosas católicas, que perduraram até a Reforma Pombalina do final do século XVIII. A partir de então, foram introduzidas ideias iluministas e as primeiras experiências de laicização do ensino influenciado pelo Racionalismo

No início do século XIX, após a vinda da Família Real portuguesa ao Brasil, percebemos que, gradativamente, o campo da Arte foi recebendo maior atenção na medida em que os sujeitos, a educação escolar e a sociedade se conscientizavam de sua importância. Segundo Ferraz e Fusari (2009):

A transferência da Corte em 1808 mudou o cenário político, econômico, educacional e cultural brasileiro. [...] Assim. vem ao Brasil a convite do rei a Missão Artística Francesa, com a incumbência de reformular os padrões estéticos vigentes. [...] foi criada a Escola Real de Ciências, Artes e Ofícios do Rio de Janeiro [...], transformada, dez anos depois,

\section{Trânsitos Interdisciplinares em Artes \\ Bárbara Tavares dos Santos, Liliane Scarpin S. Storniolo, Renata Patrícia da Silva (Organizadoras)}


em Imperial Academia e Escola de Belas Artes (FERRAZ; FUSARI, 2009, p. 42).

É importante observar que, além do periodo de 10 (dez) anos para sua efetiva inauguração, a Escola de Belas Artes atendia à realeza e à nobreza brasileiras. Aos escravos, desde o período da permanência dos Jesuítas no Brasil, incumbia a arte manual. Apesar da importância da referida missão francesa, vale lembrar que a estética estrangeira se instalou à revelia da arte barroca brasileira e. por isso foi designada como "invasão cultural", que representou um obstáculo à ampliação da tradição da arte colonial (BARBOSA; COUTINHO, 2011).

As atividades da Academia Imperial de Belas-Artes célula mater. no ensino da Arte no Brasil - iniciaram somente 10 (dez) anos após a vinda de artistas franceses, membros renomados do Instituto de Artes da França, os quais estavam incumbidos de organizar um museu de artes e o ensino da Arte, o que foi chamado de Escola Real de Ciências, Artes e Ofícios. Para Barbosa (2012. p. 16), a Arte era concebida a partir de preconceitos, já que "[...] estivera a serviço do adorno do Reinado e do Império, e [...] servira à conservação do poder."

Segundo Barbosa (2012), os preconceitos em relação à Arte já existiam e remontam o periodo jesuítico que moldou o espírito nacional e a valorização das atividades de ordem literária, a exemplo da poesia, visto que as artes manuais eram relegadas aos escravos, da qual a classe dominante sempre teve aversão.

Aulas de Desenho eram previstas já no currículo do Seminário de Olinda, fundado em 1800. Não há conhecimento acerca de metodologias de ensino no campo do desenho: "Não sabemos quais os métodos empregados no ensino do Desenho. mas é indicativo de uma nova abordagem educacional, sua inclusão no curriculo, como também o é a criação de uma aula régia de Desenho e figura em 1800" (BARBOSA, 2012, p. 23).

Com a vinda da Família Real, Dom João VI centrou esforços no desenvolvimento de profissões técnicas e científicas. Os cursos de Desenho criados no Rio de Janeiro, em 1818, em Vila

\section{Trânsitos Interdisciplinares em Artes}


Rica e na Bahia, em 1817, não tiveram êxito em função ao "horror ao trabalho manual" desenvolvido na formação da classe dominante brasileira, em razão da exploração do trabalho escravo (BARBOSA, 2012, p. 26). Isso contribuiu para a desvalorização das atividades manuais e técnicas, até o final do século XIX, quando ainda um quarto da população era composto por escravos.

A importante contribuição que os artistas franceses propiciaram ao país no processo de laicização da arte não se repetiu em sua democratização. Por se acreditar que a arte era privilégio de artista, o acesso a ela se deu a alguns "poucos felizes" que se dedicaram a esses exercicios. À aristocracia coube apreciar e comprar, aos artistas, a criação, conforme Barbosa (1978) em Teoria à Prática da Educação Artística. Sobre a Academia de Belas Artes, o viajante suíço naturalizado norte americano Luiz Agassiz (1938), durante sua viagem ao Brasil nos anos de 1865 e 1866. descreveu que, ainda que fosse cedo para fazer comentários ou críticas, pouco valor era conferido à Arte e aos livros:
As artes são muito desprezadas no Brasil e é mediocre o interesse que despertam são tão raros os quadros quanto os livros nas casas brasileiras. Conquanto o Rio de Janeiro possua uma Academia de Belas Artes e uma escola de escultura, tudo isso ainda está por demais na infância para merecer um comentário ou uma crítica (AGASSIZ, 1938, p. 566).

O acesso aos bens culturais era negado a parcelas inteiras da população brasileira. Costa (1969) aponta a proibição de leitura dos clássicos franceses pelos inconfidentes e pelos revolucionários pernambucanos, dentre eles, Tiradentes. Contudo, não somente os franceses foram considerados perigosos pelos grupos dirigentes, mas também os ingleses. Por influência do pensamento ilustrado no movimento de Independência, os grupos dirigentes buscavam evitar o acesso das concepções e conteúdo dos autores desses países. Quanto ao ensino superior de Artes, Barbosa (2012) afirma:

A organização do ensino artístico de grau superior antecedeu de muitos anos sua organização a nivel

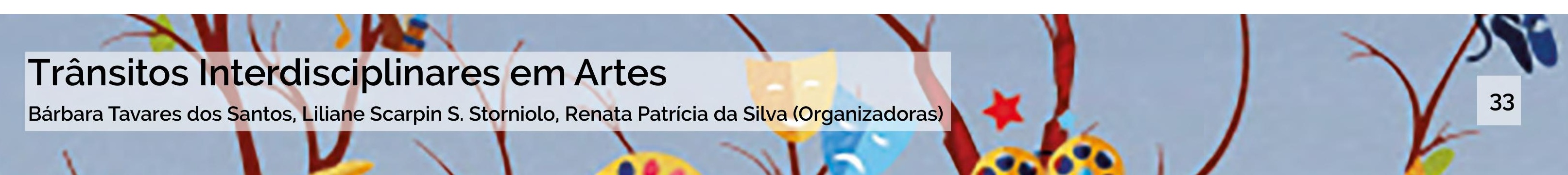


primário e secundário, refletindo uma tendência geral da Educação Brasileira, envolvida desde o início do século XIX na preocupação prioritária com o ensino superior, antes mesmo de termos organizado nosso ensino primário e secundário (BARBOSA, 2012, p. 15).

Com o processo de industrialização, ainda incipiente, em fins do terceiro quarto do século XIX, o estímulo ao Desenho Geométrico deu-se de maneira intensa e sempre com a intenção de estabelecer a união entre Arte como criação e como técnica, especialmente aplicada à indústria. Ao incluir essa disciplina no currículo escolar, acreditavam os homens da política, dentre eles Rui Barbosa $^{5}$ (1981) que, somada à defesa de uma educação nacional

5 Rui Barbosa foi deputado provincial na Bahia em 1878 e, no ano seguinte, deputado geral. Permaneceu na vida pública por quase 50 anos. Estudou Direito, foi autor de diversos projetos e pareceres sobre A Reforma do Ensino Secundário e Superior (1882) e a Reforma do Ensino Primário e várias Instituições da Instrução Pública (1883). Era autodidata e conhecedor de vários idiomas, que o permitiam conhecer os acontecimentos ao redor do mundo, deixou uma biblioteca com mais de 35 mil volumes (MACHADO, 1999). para todos, ${ }^{6}$ o país trilharia o caminho do progresso tão almejado. No entanto, seriam necessárias reformas na educação: "Reforma dos métodos e reforma do mestre: eis numa expressão completa. a reforma escolar inteira; eis o progresso todo e, ao mesmo tempo, toda a dificuldade contra a mais endurecida de todas as rotinas, - a rotina pedagógica" (BARBOSA, 1981, p. 33). Rui Barbosa se referia à escola como um lugar onde a criança, até então semelhante a uma flor energizada, entra "para experimentar uma vida vegetativa da planta, dos efeitos da privação do sol, do ar livre, de todas as

6 Rui Barbosa (1849-1923) fez importante defesa da necessidade da educação nacional por acreditar que somente pelo caminho da educação o país se desenvolveria, pois a ignorância era o grande inimigo da nação: "[...] a ignorância popular, mãe da servilidade e da miséria. Eis a grande ameaça contra a existência constitucional e livre da nação" (BARBOSA, 1947, p. 121). Rui Barbosa também criticou o sistema educacional e propôs alternativas, ao postular que: "No sistema em voga entre nós todos os conhecimentos resultantes dessa série de operações mentais se procuram levar ao espírito do aluno catequeticamente, reduzida a inteligência da criança à mais inativa receptividade [.... 0 ponto de apoio da educação deve, portanto, mudar; deixar de assentar-se exclusivamente no espírito do mestre, para se fixar principalmente na energia individual, nas faculdades produtoras do aluno" (BARBOSA, 1981, p. 54-6).

\section{Trânsitos Interdisciplinares em Artes}

Bárbara Tavares dos Santos, Liliane Scarpin S. Storniolo, Renata Patrícia da Silva (Organizadoras) 
condições essenciais à natureza da pobre criaturinha condenada" (BARBOSA, 1981, p. 34).

Logo, Rui Barbosa mostrou-se um homem bastante preocupado com a formação escolar do povo, e suas ideias e propostas de reforma do ensino fizeram eco no início do século $X X$, juntamente com a defesa e a necessidade de implantação do ensino da Arte nas escolas primárias e secundárias. Entretanto, para Barbosa (2012), a defesa do ensino da Arte permanecia reduzida ao ensino do Desenho.

Desde os inícios do século XIX era o Desenho, dentro da pedagogia neoclássica, o elemento principal do ensino artístico, levando à precisão da linha e do modelado [...]. No século XX, a ênfase no Desenho continuaria nos argumentos a favor de sua inclusão na escola primária e secundária, os quais se orientaram no sentido de considerá-lo mais uma forma de escrita que uma arte plástica (BARBOSA, 2012, p. 34)
Importante observar que o incentivo ao Desenho se deu também como uma forma de apontar para o preconceito que estava presente no ensino da Arte (BARBOSA, 2012). Se, com a educação jesuítica houve a intensificação da educação literária para a nobreza, aos demais restavam as atividades manuais.

No final do século XIX, a sociedade brasileira passou por mudanças importantes. A abolição do trabalhador escravo (1888) provocou um redirecionamento no tocante aos rumos da preparação de mão de obra do trabalhador, agora livre. que deveria atender as necessidades do desenvolvimento da nação. Em seguida, a Proclamação da República (1989) alterou substancialmente os rumos político-administrativos do país. Nesse contexto, liberais e positivistas empreenderam esforços no sentido de propor e realizar reformas em todos os setores da sociedade. especialmente no campo educacional, o ensino primário e secundário, por acreditarem se constituir na área estratégica para promover mudanças que concebiam necessárias.

\section{Trânsitos Interdisciplinares em Artes}

Bárbara Tavares dos Santos, Liliane Scarpin S. Storniolo, Renata Patrícia da Silva (Organizadoras) 
Assim, havia a necessidade de instrução da nação, necessidade de "humanizar e civilizar" a sociedade que até então era educada pelo castigo. Cabe indicar que esse "humanizar e civilizar", para liberais e positivistas, é compreendido como adequação às demandas da sociedade capitalista que se consolidava. O povo precisava de educação para que a sociedade progredisse, principal defesa do positivismo. Saber ler e escrever era fundamental para formar-se a República Federativa. Os setores sociais de grupos dirigentes e de educadores defendiam a ideia de educação para todos, mas não no sentido de promover sua gratuidade (BIRCK. 2003).

O ensino da Arte foi significativo ao contribuir para a formação por meio do desenho geométrico que, com a abolição da escravatura, iniciou um "processo de respeitabilidade do trabalho manual" (BARBOSA, 2012, p. 30). No mesmo periodo em que o Brasil inicia sua primeira etapa de "revolução industrial", "as Artes aplicadas à indústria e ligadas à técnica começaram a ser valorizadas como meio de redenção econômica do país e da classe obreira, que engrossara suas fileiras com os recém-libertos" (BARBOSA, 2012, p. 30)

Com o advento da República e nas duas primeiras décadas do século XX, chega às escolas brasileiras o novo método de ensino, não mais centrado no professor e no conteúdo, próprio da Escola Tradicional, mas voltado para o aluno e seu processo de aprendizagem, proposto pela Escola Nova. Assim, pela primeira vez, a finalidade da Arte na educação visava o "desenvolvimento do impulso criativo", para o qual os "psicólogos começaram a enfatizar a relação existente entre os processos afetivo e cognitivo" (BARBOSA, 1978, p. 44). Desse modo, autores importantes como Anísio Teixeira, Fernando de Azevedo, Loureço Filho, entre outros,

\section{Trânsitos Interdisciplinares em Artes}

Bárbara Tavares dos Santos, Liliane Scarpin S. Storniolo, Renata Patrícia da Silva (Organizadoras) 
prepararam um fértil terreno na educação brasileira para as teorias de John Dewey?

Com a adesão das propostas da Escola Nova pela Reforma da Instrução Pública do Estado de São Paulo, dirigida por Sampaio Dória em 1920, houve um movimento de inclusão da Arte nas escolas primárias como atividade de integração entre a Arte e os conteúdos de Geografia, que era concebida como forma de fixação dos conteúdos por meio da cópia dos desenhos dos materiais (BARBOSA, 1978).

Logo, a metodologia no campo da Arte sofreu importante modificação a partir da influência da Semana de Arte Moderna de

7 Em Aranha (2006, p. 261), pode-se ler que o "filósofo e pedagogo John Dewey (18591952), influenciado pelo pragmatismo de William James, preferia usar as expressões instrumentalismo ou funcionalismo para identificar sua teoria [...]. Para Dewey o conhecimento é uma atividade dirigida que não tem um fim em si mesmo, mas está voltado para a experiência". Para Dewey, as ideias são verdadeiras à medida que funcionam como orientadoras da ação, têm valor instrumental e servem para resolver problemas colocados na experiência humana. A escola, numa proposta de educação ativa, deve ter a criança como centro e, portanto, centrada nos principais interesses da criança (ARANHA, 2006).
1922. Artistas como Mário de Andrade e Anita Malfatti, influenciados pelos conhecimentos artísticos europeus e pelas teorias expressionistas, introduziram a ideia de livre-expressão para a criança: "A ideia da livre-expressão, originada no expressionismo, levou a ideia de que a Arte na educação tem como finalidade principal permitir que a criança expresse seus sentimentos e a ideia de que a Arte não é ensinada, mas expressada" (BARBOSA, 1978, p. 45).

No documento do Manifesto de 1932, observa-se que. com a necessária expansão de vagas para a educação escolar e visando mudanças sociais emergentes, o plano de reconstrução nacional, aponta para a necessidade de identificar a "cultura própria" ou a "cultura geral" da nação (AZEVEDO, 2010, p. 34). Era imprescindivel promover uma formação cultural múltipla e diversa que auxiliasse na compreensão da amplitude da vida humana e social, na compreensão dos sujeitos para além do efêmero e do aparente, enfim, uma cultura que ampliasse sua cosmovisão.

Conforme Azevedo (2010, p. 53). "I...] a arte e a literatura têm efetivamente uma significação social, profunda e múltipla [...]", logo,

\section{Trânsitos Interdisciplinares em Artes}


a arte, a literatura e os valores culturais não poderiam ser negados. Porém, o periodo ditatorial que se estende de 1937 a 1945, afastou Anísio Teixeira de suas funções da educação, um dos mais importantes representantes da ação educativa renovadora. A perseguição política contribuiu para que o movimento, que vinha sendo realizado e divulgado por educadores, artistas e psicólogos, recebesse críticas contundentes da ala conservadora (BARBOSA, 1978).

Quanto à legislação, no que se refere ao ensino da Arte, no final do século XIX, já se defendia a necessidade de um plano nacional de educação para todos. $O$ Desenho passou a ser obrigatório no currículo escolar do ensino primário de acordo com a Lei Orgânica do Ensino Primário. No texto da lei, os termos "Desenho e trabalhos manuais" revelam que a legislação postulava a Arte na perspectiva da tendência como técnica, apesar de a Arte vista como livre expressão já vinha sendo discutida há algum tempo.

Nessa diretriz, a Arte continuou sendo compreendida no currículo como uma linguagem técnica a serviço da ciência, com sentido utilitário ao visar o preparo da mão de obra fabril. Dito de outro modo, o desenho tinha, como propósito, instrumentalizar e formar o artesão para os espaços de trabalho que surgiam no processo de industrialização.

No ano de 1946, foi aprovada a Lei Orgânica do Ensino Normal por meio do Decreto-Lei n 8.530/46. Em seu art. 1², cap. I, título I, dentre as finalidades, duas preveem: "1. Prover à formação do pessoal docente necessário às escolas primárias; e 2. Habilitar administradores escolares destinados às mesmas escolas" (BRASIL, 1946). Observa-se que não há nenhuma referência à formação do professor de "Desenho e trabalhos manuais" ou de "Canto orfeônico", disciplina prevista também na Lei. Do mesmo modo, não há referência quanto à formação dos professores primários e da habilitação para administradores dos ciclos de Ensino Normal em seus art. $2^{\circ}$ e $3^{\circ}$, do capítulo II:

Art. $2^{\circ} \bigcirc$ ensino normal será ministrado em dois ciclos. $O$ primeiro dará o curso de regentes de ensino primário. em quatro anos, e o segundo, o curso de formação de professores primários, em três anos.

\section{Trânsitos Interdisciplinares em Artes}


Art. $3^{\circ}$ Compreenderá ainda, o ensino normal cursos de especialização para professores primários, e cursos de habilitação para administradores escolares do grau primário (BRASIL, 1946)

A Constituição Republicana promulgada em 1946 garantia o ensino primário gratuito e obrigatório a todos. ${ }^{8}$ Quanto ao ensino religioso, sua matrícula era facultativa. Nessa Constituição se fazia presente também a competência da União de fixar em seu art. $5^{\circ}$. inciso XV, alínea d, do capítulo I, as "diretrizes e bases da educação nacional". Esse dispositivo foi um passo importante para a União na construção de uma lei nacional única que regulasse e orientasse a educação escolar brasileira.
A partir da prerrogativa de elaboração de uma diretriz nacional para a educação, em 1947, uma comissão iniciou os trabalhos de elaboração do anteprojeto por meio de exposição dos motivos, debates, discussões e encaminhamentos até a sua consecução. Treze anos depois, a LDB n 4.024/61 foi aprovada. ${ }^{9} 0$ Título VI, Capítulo II, que tratava do Ensino Primário, determinava, em seu art. 25, que o "Ensino Primário tem por fim o desenvolvimento do raciocínio e das atividades de expressão da criança, e a sua integração no meio físico e social." O "ensino primário será ministrado, no mínimo, em quatro séries anuais", podendo o sistema de ensino, conforme parágrafo único "estender a sua duração até seis anos, ampliando, nos dois últimos, os conhecimentos do aluno

8 Na Constituição de 1946, Capítulo II do Título IV, da Educação e da Cultura, em seu art. 168 que trata da legislação do ensino, o inciso I versa que "o ensino primário é obrigatório e só será dado na língua nacional", já no inciso II institui-se que "o ensino primário oficial é gratuito para todos; o ensino oficial ulterior ao primário sê-lo-á para quantos provarem falta ou insuficiência de recursos."

9 Essa foi a primeira LDB brasileira que vigorou até 1996, entremeadas de duas reformas educacionais, reforma do Ensino Superior de $n^{\circ} 5.440 / 68$ e a reforma da educação básica de $n^{\circ} 5.692 / 71$

\section{Trânsitos Interdisciplinares em Artes \\ Bárbara Tavares dos Santos, Liliane Scarpin S. Storniolo, Renata Patrícia da Silva (Organizadoras)}


e iniciando-o em técnicas de artes aplicadas, adequadas ao sexo e à idade" (art. 26 - grifo nosso) ${ }^{10}$

Nesse contexto, seguindo ainda a proposta de instrumentalização, foram incluidas nos currículos escolares as técnicas de Artes aplicadas de forma introdutória e visando na formação nas Artes aplicadas e nas Artes industriais. Por outro lado, observa-se que a concepção de educação por meio da Arte mira-se em um ensino artístico para a expressão, os sentimentos e emoções do aluno, característica da proposta moderna que dissemina a ideia de que, no estado de livre expressão, o sujeito é capaz de criar livremente a partir de suas experiências.

A subjetividade romântica, concepção advinda do Romantismo, caraterizada pela imaginação e pela criatividade individual, pela liberdade de expressão e ênfase nas emoções e

10 A estrutura de ensino das demais etapas ficou compreendida com o ensino ginasial de quatro anos, subdividido em secundário, comercial, industrial, agrícola e normal; e de três anos para o ensino colegial, com as mesmas subdivisões, e o Ensino Superior. na educação do sentimento, são atributos recorrentes do ensino artístico na Escola Nova. Dessa forma, a Arte não teria conteúdos específicos para serem estudados nem um ensino centrado nos fundamentos da psicologia da escola renovada, na qual a atividade artística teria uma finalidade em si mesma, sendo a garantia da expressão da criança. Contudo, ainda hoje se fazem presentes na concepção do ensino da Arte na educação escolar, conforme verificamos nas repostas aos questionários aplicados na pesquisa do doutorado.

Em se tratando da formação do magistério para o Ensino Primário e Médio, o Ensino Normal objetivava a formação dos professores, supervisores, orientadores e administradores. A primeira LDB, em seu art. 53, capítulo VI, que trata da formação docente para o ensino primário, previa: "a) escola normal de grau ginasial, no mínimo de quatro séries anuais, onde além das disciplinas obrigatórias do curso secundário ginasial será ministrada preparação pedagógica; b) em escola normal de grau colegial, de três séries anuais, no mínimo, em prosseguimento ao vetado grau

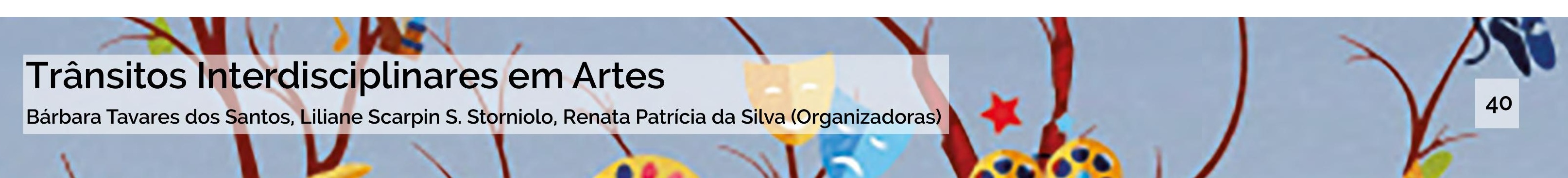


ginasial." Enquanto o texto da Lei trata da formação do professor em geral, o que havia no Brasil nessa época sobre a formação do professor de Arte estava estruturado na Escolinha de Artes do Brasil.

O país passou por mudanças profundas no campo da politica a partir de 1964. O regime militar de governo interferiu autoritariamente em todos os setores, principalmente no desaparecimento do Estado de Direito, cujas consequências foram sentidas imediatamente no campo da educação. Na Universidade de Brasilia, ocorreu a intervenção de forças militares em seu Câmpus seguida da demissão, prisão e perseguição de professores e alunos. Essa ação do governo inviabilizou o avanço de um projeto de reformulação universitária que vinha sendo implantado.

Quanto à educação, o Brasil foi diretamente influenciado pelo sistema de ensino norte-americano que se corporificou com os acordos entre o Ministério da Educação e a Agência dos Estados Unidos para o Desenvolvimento Internacional (MEC/USAID). conduzindo as reformas educacionais no periodo da ditadura
(ROMANELLI, 2007). Nesse sentido, Pimenta e Anastasiou (2002) observam que essa medida reforçou o caráter profissionalizante do ensino de $2^{\circ}$ grau, para atender a necessidade do que foi designado como desenvolvimento econômico nacional.

Separa-se aí a pesquisa do ensino, deixando à graduação a responsabilidade de formação de quadros profissionais o que reforça o caráter profissionalizante do modelo napoleônico ${ }^{11}$ - e destinando à pós-graduação a responsabilidade da pesquisa (PIMENTA; ANASTASIOU, 2002, p. 152).

Esses acordos, com intuito não de impedir, porém de dificultar ou mesmo de não incentivar a produção do conhecimento

11 O modelo napoleônico de universidade traz, em sua essência, características do modelo jesuítico de ensino, ou seja, centrado no professor, este como transmissor do conhecimento, pautado numa proposta pedagógica de manutenção, não havendo intencionalidade para a criação do conhecimento (PIMENTA; ANASTASIOU, 2002).

\section{Trânsitos Interdisciplinares em Artes}

Bárbara Tavares dos Santos, Liliane Scarpin S. Storniolo, Renata Patricia da Silva (Organizadoras) 
na graduação, provocou a estagnação da formação crítica, o que propiciou a construção de uma universidade funcional.

Decorrido menos de uma década da aprovação da primeira LDB, ela passou por reformulações após aprovada a Reforma Educacional do Ensino Superior de 1968. A Lei n 5.540/68, em seu capítulo 1 , art. $1^{\circ}$ trata do objetivo do Ensino Superior da seguinte forma: tem por objetivo a pesquisa, o desenvolvimento das ciências, letras e artes e a formação de profissionais de nível universitário

Até a aprovação dessa Reforma Universitária, Lei $n^{\circ}$ 5.540/68, o ensino da Arte, de influência da Escola Nova, centrava-se nas atividades de desenho e canto orfeônico em uma perspectiva de livre expressão. A formação do professor de Arte se deu por meio de cursos de curta duração a partir dos anos 1970, visando atender a demanda por profissionais nas diversas áreas. Importante observar que a ideia de livre expressão chegou ao seu ápice na década de 1970, quando se introduziu a atividade de Educação Artística no currículo escolar, revelando seu caráter pragmático, com o intuito de atender as demandas capitalistas e a falta de espaço humanizador da escola.

A educação de nível básico também passou por reformulações, conforme a Lei n 5.692/71, voltada aos alunos do $1^{\circ}$ e $2^{\circ}$ graus e que objetivava proporcionar uma formação necessária ao desenvolvimento das potencialidades do educando. Em grande medida, o ensino de $1^{\circ}$ grau destinava-se à criança e ao pré-adolescente, de acordo com as fases de desenvolvimento, e a formação em $2^{\circ}$ grau destinava-se à formação integral do adolescente. A primeira e importante alteração nessa Lei ocorreu quanto à obrigatoriedade da oferta da atividade de Educação Artística nos currículos plenos dos estabelecimentos de $1^{\circ}$ e $2^{\circ}$ graus. Com relação à nomenclatura, a disciplina de Técnicas de Artes Aplicadas passou a se chamar de Educação Artística, conforme consta no art. $7^{\circ}$, do capítulo 1.

De acordo com o Parecer n 540/1977, a Lei, em seu art. $7^{\circ}$, não encara a Educação Artística como matéria e nem mesmo como disciplina, mas como atividade. Para os relatores

\section{Trânsitos Interdisciplinares em Artes}


desse Parecer, houve a preocupação em relação ao cumprimento desse artigo visto que os objetivos não foram compreendidos e. consequentemente, foram distorcidos pelos professores, por inexperiência e por falta de recursos humanos, conforme apontam os relatores:

Preocupadas com o cumprimento formal dos dispositivos legais, nossas escolas vêm consignando em seus planos a presença destes elementos, aos quais atribuem, em geral, cargas horárias semanais que deixam clara a incompreensão do papel desses componentes no contexto curricular e revelam ao mais arguto a inviabilidade de serem alcançados, por tais meios, os objetivos que se desejam (PARECER n540/77, p. 134)

Por outro âmbito, não havia realmente uma efetiva preocupação por parte dos legisladores em relação ao cumprimento do currículo no processo de ensino e aprendizagem, ou seja, "o aluno e o professor ocupam uma posição secundária, porque o elemento principal é o sistema técnico de organização da aula e do curso" (FERRAZ; FUSARI, 2010, p. 32).

No campo da Arte, novos rumos foram delineados, na medida em que, com a nova nomenclatura, os professores foram convidados para ministrar todas as linguagens em Arte. Essa reforma estabeleceu um novo conceito de ensino da Arte: a prática da polivalência. Um mesmo professor deveria ensinar alunos da $1^{a}$ à $8^{a}$ séries Artes Cênicas, Artes Plásticas e Música. E, para formar um professor polivalente, foram criados, a partir de 1973, cursos de licenciatura em Educação Artística com duração de dois anos. "Após este curso, o professor poderia continuar seus estudos em direção à licenciatura plena, com habilitação especifica em artes plásticas. desenho, artes cênicas ou música" (BARBOSA; COUTINHO, 2011, p. 83).

Na análise da reforma educacional de 5.692/71, Ribeiro (1993) observa que seus objetivos têm a impressão de ser uma reforma de base liberal, humanista moderna, ou seja, que entende que o sujeito deve ser considerado, em sua existência real, como

\section{Trânsitos Interdisciplinares em Artes}

Bárbara Tavares dos Santos, Liliane Scarpin S. Storniolo, Renata Patrícia da Silva (Organizadoras) 
individuos diferentes entre si, isto é, com uma pedagogia que centra-se na vida, na existência, na atividade e que deve dar conta da interação entre os individuos. "Orientada pelos princípios da pedagogia nova, a prática pedagógica, tal como se patenteia no escolanovismo, irá valorizar a atividade, as experiências, a vida, os interesses dos educandos" (SAVIANI, 2012, p. 68).

Entretanto, a Pedagogia Tecnicista trabalha a partir dos pressupostos da objetividade, da neutralidade e da positividade do conhecimento e, como teoria, vai tentar explicar o fenômeno educativo a partir de uma descrição empírica que é a base da educação Tecnicista. Conforme Ribeiro (1993).

[...] passa-se à conclusão de que a inspiração é em última instância de base tecnicista, quando do exame dos objetivos reais, orientados por uma compreensão sobre o contexto no bojo do qual a lei foi projetada e aprovada. Revela-se assim a ênfase na quantidade e não na qualidade, nos métodos (técnicas) e nãos nos fins (ideais), na adaptação e não na autonomia, nas necessidades sociais e não nas aspirações individuais, na formação profissional em detrimento da cultura geral (RIBEIRO, 1993. p. 194-195).

A proposta Tecnicista de ensino estava nacionalmente em ampla expansão, como forma de atender às exigências do mercado, que necessitava de mão de obra para fazer valer as necessidades de desenvolvimento econômico capitalista da sociedade brasileira. Segundo Barbosa (1978), na década de 1970, havia uma carência de unidades escolares que não tinham professores formados adequadamente para o ensino da Arte. Não havia cursos de graduação nesta área ${ }^{12}$.

Os profissionais que trabalhavam eram egressos de Escolas de Belas Artes, de Escolas de Desenho Industrial ou

12 Segundo Barbosa, até 1970, não havia nenhum livro de Arte-Educação traduzido no Brasil, e consumia-se as traduções argentinas, em especial as obras de Lowenfeld, logo "[...] a lowenfeldmania que domina os professores de Arte no Brasil reflete a ausência de contato com outras obras sobre o assunto" (BARBOSA, 1978, p. 35-6).

\section{Trânsitos Interdisciplinares em Artes}

Bárbara Tavares dos Santos, Liliane Scarpin S. Storniolo, Renata Patricia da Silva (Organizadoras) 
mesmo de Escolas de Artes e Comunicação. No currículo desses cursos, não havia obrigatoriedade legal de estudos específicos acerca de arte-educação ${ }^{13}$. Embora, esses profissionais pudessem ser eximios sabedores da Arte e do Desenho Geométrico, em geral, pouco sabiam "acerca dos princípios filosóficos, psicológicos e metodológicos da Arte-Educação" (BARBOSA, 1978, p. 35).

Soma-se a essa questão o problema da ausência de formação para a docência na área, apesar da Lei, com pouquíssimas escolas que mantinham professores especializados em Arte, exceto nas Instituições particulares. Durante a Semana de Arte em Ensino, que ocorreu em 1980, os arte-educadores tiveram a oportunidade de debater questões políticas de Arte e Educação, o que contribuiu para fortalecer os professores da área tanto política quanto academicamente, e isso resultou, em 1983, na criação do Programa

13 A expressão "educação através da arte" foi cunhada por Herbert Read, em 1943, e, com o passar do tempo, foi reelaborada e simplificada ao que conhecemos hoje como arteeducação. de Pós-Graduação em Artes na Universidade de São Paulo, com especialização, mestrado e doutorado (BARBOSA; COUTINHO, 2011).

Quanto à legislação, é importante indicar que as diretrizes contidas nas Leis n 5.540/68 e n 5.692/71 vigoraram para além do periodo ditatorial. Foram, pelo menos, oito anos de debates e disputas intensas entre deputados e senadores. No contexto de uma nova Constituição, a do ano de 1988, em um espaço político novamente democrático, foi aprovada a LDB de 1996, nº 9.394. que estabelecia a liberdade de ensinar, divulgar, aprender e pesquisar Arte. No art. 26, parágrafo $2^{\circ}$, foi explícito que "o ensino de Artes se constituiria em um componente curricular obrigatório em todos os níveis da educação básica, objetivando promover o desenvolvimento cultural." Porém, a redação desse artigo sofreu alteração no Projeto de Lei no 7.032-B de 13/07/2010: "O ensino da arte, especialmente em suas expressões regionais, constituirá componente curricular obrigatório nos diversos níveis da educação

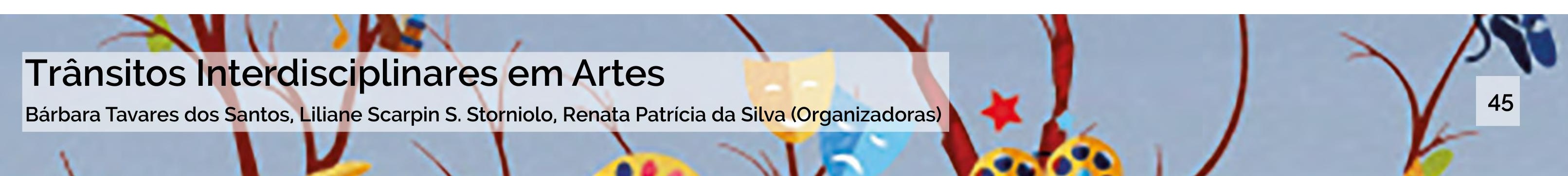


básica, de forma a promover o desenvolvimento cultural dos alunos".

Desde então, a disciplina de Arte tem conquistado espaço no interior da escola, porém nem sempre há estrutura material e corpo docente, necessários à sua concretização. Como as demais áreas do conhecimento, a legislação, por si só, não garante a efetivação das leis nas escolas, inclusive por omissão e descaso do próprio poder público para com a educação em geral no Brasil.

Nessa perspectiva, o CNE, na Resolução no 1 , de 15 de maio de 2006, institui as DCNs para o Curso de Graduação em Pedagogia, Licenciatura. Assim, as diretrizes, ao determinar que o lócus privilegiado para a formação de professores da Educação Infantil, e da $1^{\text {a }}$ fase do Ensino Fundamental, levou as IESs a rever seus projetos pedagógicos traçando outros rumos visando à nova identidade do Curso de Pedagogia. Cabe apontar que, embora a preocupação com a formação do pedagogo tornou-se relevante, o que se observa nos cursos de graduação é a formação precária em todas as áreas.
Quanto ao lugar que a Arte ocupa, de acordo com os DCNs (2006, p. 2), o pedagogo estará apto a: "[...] ensinar Língua Portuguesa, Matemática, Ciências, História, Geografia, Artes, Educação Física, de forma interdisciplinar e adequada às diferentes fases do desenvolvimento humano". O ensino da Arte mostrase no mesmo patamar de relevância que as demais áreas do conhecimento, e isso representa que os esforços empreendidos pelos profissionais, na luta política, mostravam-se necessários e foram reconhecidos. Assim, a Arte como conhecimento incorporado ao currículo da educação básica pode, de forma mais contundente, contribuir com a formação e o desenvolvimento do sujeito.

O que se tem efetivamente na escola pública, nesse momento, configura-se com o pedagogo desempenhando a função docente na disciplina de Arte, sendo que deve contemplar no seu trabalho de ensino, as quatro linguagens - artes visuais, dança, música e teatro. Portanto, os PPCs revelam que a quantidade de disciplinas ofertadas não é o suficiente devido à extensão e

\section{Trânsitos Interdisciplinares em Artes}

Bárbara Tavares dos Santos, Liliane Scarpin S. Storniolo, Renata Patrícia da Silva (Organizadoras) 
profundidade do conhecimento da Arte. Isso promove a formação de um professor generalista na área de Arte.

Assim, é possivel encontrar soluções para a defasagem do ensino da Arte nos anos de escolarização inicial, isto é, formar o educador nessa área. Contudo, a Lei 13.278/2016, ao estabelecer a obrigatoriedade das quatro linguagens no currículo dos diversos niveis da educação básica, se contradiz com a realidade da maioria das escolas brasileiras. O pedagogo continuará responsável por ministrar essa disciplina e não o professor de Arte.

Os PCNs, na análise de Barbosa e Coutinho (2011), tolhem a autonomia do professor e desconsideram todo o trabalho curricular até então desenvolvido pelos pesquisadores brasileiros.

A nomenclatura dos componentes da aprendizagem triangular designados como fazer arte (ou produção). leitura da obra de arte e contextualização foi trocada para produção, apreciação e reflexão (da primeira a quarta séries) ou produção, apreciação e contextualização (na quinta a oitava séries) (BARBOSA; COUTINHO, 2011, p. 87)
Podemos ver que há conflito de interesses estabelecido nos PCNs de 1997: "Os PCN brasileiros, dirigidos por um educador espanhol, desistoricizam nossa experiência educacional para se apresentarem como novidade e receita para a salvação da educação nacional" (BARBOSA; COUTINHO, 2011, p. 87). Por não atingirem o objetivo com esse documento, o próprio Ministério da Educação editou uma cartilha denominada de Parâmetros em Ação, com o intuito de apoiar e incentivar o uso dos PCNs.

As políticas públicas em educação valem-se da legislação para influenciar diretamente na formação de professores. Para Silva (2013), a introdução de referenciais internacionais, por meio do técnico espanhol Cesar Coll, reforça a influência sofrida no campo da educação. Silva (2013) enfatiza também uma crítica de Barbosa (1997) a essas práticas no contexto da criação dos PCNs em Arte, ao afirmar que: "[...] o Ministério da Educação no Brasil optou por confiar a um único indivíduo, estrangeiro, o poder de julgar, avaliar. aprovar ou desaprovar, decidir, enfim, o que vai ser o nosso currículo nacional como um todo" (BARBOSA, 1997, apud SILVA, 2013, p. 13).

\section{Trânsitos Interdisciplinares em Artes}

Bárbara Tavares dos Santos, Liliane Scarpin S. Storniolo, Renata Patrícia da Silva (Organizadoras) 
Nessa perspectiva, Martins (2018), durante a II Etapa do Evento de Extensão do Programa de Formação Docente Continuada (PROFOR), realizado na Universidade Federal do Tocantins (UFT), Câmpus de Miracema, no dia 26 de novembro de 2018, enfatiza que a BNCC, prevista na LDB, como política de Estado, é um projeto legítimo, porém apresenta em sua essência: "um caráter conservador, revela com grande ênfase os interesses dos grupos privatistas de educação e põem em risco a autonomia e a liberdade dos professores".

Constantemente a LDB n 9.394/96 vem sendo reformulada visando atender principalmente aos legisladores e empresários da educação, mesmo que nem sempre os sujeitos diretamente envolvidos com a educação concordem totalmente com as reformas. A aprovação da Base Nacional Comum Curricular (BNCC), documento homologado pela Portaria $n^{\circ}$ 1.570. publicada no de 21/12/2017, define o conjunto das aprendizagens que todos os alunos da educação básica deverão desenvolver. No Ensino Fundamental, o currículo está dividido em áreas do conhecimento, e o componente curricular de Arte faz parte da área de linguagens, juntamente com Lingua Portuguesa, Língua Inglesa e Educação Física.

Para a etapa do Ensino Médio, aprovada pelo CNE, em 4 de dezembro de 2018, centrada no desenvolvimento das competências, o currículo foi dividido em quatro grandes áreas do conhecimento. Todavia, os componentes curriculares da $1^{\mathrm{a}}$ a $3^{\mathrm{a}}$ séries são Lingua Portuguesa e Matemática e, as demais disciplinas, conforme o documento "não exclui necessariamente as disciplinas [...] mas, sim. implica no fortalecimento das relações entre elas e a sua contextualização para apreensão e intervenção da realidade" (BRASIL, 2017, p. 32). Para tanto, exige um trabalho em conjunto com os professores no planejamento e na execução dos planos de ensino.

Na BNCC, recém aprovada, que promoveu alterações na estrutura do Ensino Médio, toma como referência o limite de 1.800 horas do total da carga horária e determina o ensino da Língua Portuguesa e da Matemática por três anos. Assim, é possivel observar que se corre o risco de a disciplina vir a ser facultativa ou até mesmo retirada do rol das disciplinas presentes.

\section{Trânsitos Interdisciplinares em Artes}


Vale ressaltar que o termo reforma, em certo sentido, persegue e impregna o campo educacional brasileiro há séculos, uma vez que essas reformas têm ocorrido sistematicamente, desde a expulsão dos Jesuitas. Há interesses diversos e contraditórios nas reformas educacionais que se estabelecem no país. Por um lado, forças convergentes à manutenção do status quo e, por outro, lutas que visam uma educação mais democrática. Esse impasse reside no interior de um conflito social ainda maior, na medida em que "A escola é um local de conflito, pela simples razão de que a sua função social é dupla: preparar trabalhadores e formar cidadãos" (PALMA FILHO, 2005, p. 39).

De acordo com Silva (2013, p. 14). "A legislação é a forma de obrigar as redes e as universidades à implementação de tais propostas hegemônicas". Assim, educa-se a classe privilegiada para comandar e fazer com que a classe dominada não se sinta subordinada, a exemplo da reforma do Ensino Médio, que desobriga a oferta de disciplinas importantes como Arte, Educação Física, Filosofia e Sociologia.
Durante a mesa-redonda no XXVII Congresso Nacional da Federação de Arte/Educadores do Brasil (CONFAEB), em Campo Grande/MS, em 16 de novembro de 2017. Silva (2017) alerta para a dimensão das políticas públicas, afirmando que essas são maiores que a sala de aula e, por isso, devem nos mover, nos preocupar e nos incomodar no interior da instituição.

[...] enquanto estamos aqui discutindo durante o Congresso. em tom preocupado, o governo está retirando, destruindo o que foi construido às duras penas historicamente, e pensar que teremos mais 20 anos pela frente sem investimentos em educação. Certeza que teremos um desmonte gradual e desanimador da educação em dimensão nacional (SILVA, 2017, p. 2017).

Por fim, o decrescente interesse e o pouco recurso aplicado nas licenciaturas, diz Silva (2017), não se vislumbra bons caminhos e alcances no campo pedagógico e de modo amplo na educação, e não será pelo curriculo que se mudará a escola, mas no envolvimento com as políticas públicas que estão em curso.

\section{Trânsitos Interdisciplinares em Artes}


A busca pela compreensão do fenômeno da educação e, quiçá caminhos que indiquem avanços mesmo que incipientes, necessita de pesquisa que vá além do que está imposto e visivel, uma vez que a aparência não representa a essência.

Portanto, compreender a Arte e os caminhos históricos do ensino da Arte na educação brasileira, na Legislação e na formação do professor demonstra a importância dessa área de conhecimento na formação e humanização do sujeito.

\section{Referências}

AGASSIZ, Luiz; AGASSIZ, Elizabeth Cary. Viagem ao Brasil (1865-1866). Trad. e notas de Edgar Süssekind de Mendonça, Biblioteca Pedagógica Brasileira. São Paulo: Ed. Nacional, 1938.

ARANHA, Maria Lúcia de Arruda. História da Educação e da Pedagogia: geral e do Brasil. 3. ed. São Paulo: Moderna, 2006.

AZEVEDO. Fernando et. al.. Manifestos dos pioneiros da Educação Nova (1932) e dos educadores 1959. Recife: Fundação Joaquim Nabuco, Editora Massangana, 2010. (Coleção Educadores). Disponivel em: http://Www. dominiopublico.gov.br/download/texto/me4707.pdf. Acesso em: 27 mar. 2018.

BARBOSA, Ana Mae Tavares Bastos. Teoria e Prática da Educação Artística. 2. ed. São Paulo: Cultrix, 1978.

BARBOSA, Ana Mae Tavares Bastos. Arte-Educação no Brasil. 7. ed. São Paulo: Perspectiva, 2012. (Coleção Debates).

BARBOSA, Ana Mae Tavares Bastos. COUTINHO, Rejane Galvão. Ensino de Arte no Brasil: aspectos históricos e metodológicos. São Paulo: UNESP/ Redefor, 2011, p. 57-112.

BARBOSA, Rui. Reforma do Ensino Primário e Várias Instituições Complementares da Instrução Pública. Ministério da Educação e Saúde. Rio de Janeiro: vol. X, 1883. Tomo I, 1947. (Obras Completas de Rui Barbosa).

\section{Trânsitos Interdisciplinares em Artes}

Bárbara Tavares dos Santos, Liliane Scarpin S. Storniolo, Renata Patrícia da Silva (Organizadoras) 
BARBOSA, Rui. Reforma do Ensino Primário e Várias Instituições Complementares da Instrução Pública. Rio de Janeiro: v. X. 1883. Tomo II, 1981. (Obras Completas de Rui Barbosa).

BIRCK, Rosemeri. O Atraso do País na visão de Luiz Agassiz (1817-1873) e José Veríssimo (1857-1916): da perplexidade à proposta de mudança. Dissertação (Mestrado em Educação). Área de Concentração Fundamentos da Educação, Universidade Estadual de Maringá/PR, 2003

BRASIL. Constituição de 18 de setembro de 1946. Disponivel em: http://Www. planalto.gov.br/ccivil_03/constituicao/constituica046.html. Acesso em: 14 abr. 2017.

BRASIL. Decreto-Lei $\mathbf{n}^{\circ} \mathbf{8 . 5 2 9}$ de $\mathbf{2}$ de janeiro de 1946. Estabelece a Lei Orgânica do Ensino Primário. Disponível em: http://www2.camara.gov.br/ legislacao/publicacoes/republica. Acesso em: 14 abr. 2017.

BRASIL. Resolução CNE/CP $\mathbf{n}^{\circ} \mathbf{2}$, de 22 de dezembro de 2017. Institui e orienta a implantação da Base Nacional Comum Curricular. Diário Oficial da União, Brasilia, 22 de dezembro de 2017. Seção 1, pp. 41 a 44. Disponivel em: http://basenacionalcomum.mec.gov.br/wp-content/uploads/2018/04/ RESOLUCAOCNE_CP222DEDEZEMBRODE2017.pdf. Acesso em: 11 ago. 2018.

BRASIL. Lei $\mathbf{n}^{\circ} \mathbf{9 . 3 9 4}$ de $\mathbf{2 0}$ de dezembro de 1996. Estabelece as diretrizes e bases da educação nacional. Diário Oficial da União, Brasilia, 23 de dezembro de 1996. Disponivel em: http://Www.planalto.gov.br/ccivil_03/leis/L9394.html. Acesso em: 2 out. 2017.
BRASIL. Resolução $\mathbf{n}^{\mathbf{0}} \mathbf{1}, \mathbf{1 5}$ de maio de 2006. Institui as diretrizes curriculares nacionais para o curso de graduação em Pedagogia, licenciatura. Diário Oficial da União, no 92, seção 1, p.11-12, 16 maio 2006. Disponivel em: http://portal. mec.gov.br/cne/arquivos/pdf/rcp01_06.pdf. Acesso em: 08 ago. 2017.

BRASIL. Lei $\mathbf{n}^{\circ} \mathbf{4 . 0 2 4}$, de 20 de dezembro de 1961. Estabelece as Diretrizes e Bases da Educação Nacional. Disponivel em: http://wwww.planalto.gov.br/ ccivil_03/leis/L4024.htmL. Acesso em: 20 ago. 2017.

BRASIL. Parecer CNE $/ \mathrm{CP} \mathrm{n}^{\circ}$ 03/2006. Institui Diretrizes Curriculares Nacionais para o Curso de Pedagogia. Diário Oficial da União, Brasilia, aprovado em 21 de dezembro de 2006. Disponivel em: http://portal.mec.gov.br/cne/arquivos/ pdf/pcpo03_06.pdf. Acesso em: 20 ago. 2018.

BRASIL. Projeto de Lei $\mathbf{n}^{\circ}$ 7.032-B de 2010. Estabelece como conteúdo obrigatório no ensino de Artes, a música, as artes plásticas e as artes cênicas. Disponivel em: http://www.camara.gov.br/sileg/integras/1368319.pdf. Acesso em: 30 nov. 2107

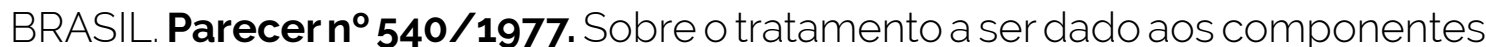
curriculares previstos no art. 7 da Lei 5.692/71. Conselho Federal de Educação. Fórum. Rio de Janeiro: jul./set. 1977, p. 131-153. Disponivel em: http:// bibliotecadigital.fgv.br/ojs/index.php/fe/article/viewFile/60447/58704. Acesso em: 07 dez. 2017

BRASIL. Lei $\mathbf{n}^{\circ} \mathbf{1 3 . 2 7 8}$ de $\mathbf{0 2}$ de maio de 2016. Estabelece a inclusão de artes visuais, dança, música e teatro na educação básica. Disponível em: https://

\section{Trânsitos Interdisciplinares em Artes}

Bárbara Tavares dos Santos, Liliane Scarpin S. Storniolo, Renata Patrícia da Silva (Organizadoras) 
WWW12.senado.leg.br/noticias/materias/2016/05/03/lei-inclui-artes-visuaisdanca-musica-e-teatro-no-curriculo-da-educacao-basica. Acesso em: 30 nov. 2017.

COSTA, Emilia Viotti da. Introdução ao Estudo da Emancipação Política do Brasil. In: MOTA, Carlos Guilherme (Org.). Brasil em perspectiva. 2. ed. São Paulo: Difusão Europeia do Livro, 1969, p. 63-124. (Coleção Corpo e Alma do Brasil).

FERRAZ, Maria Heloísa C. T.; FUSARI Maria F. de Rezende e. Arte na educação escolar. São Paulo: Cortez, 2010

FERRAZ, Maria Heloísa C. T.; FUSARI Maria F. de Rezende e. Metodologia do Ensino de Arte. 2. ed. São Paulo: Cortez, 2009

MACHADO, Maria Cristina Gomes. O Projeto de Rui Barbosa: o papel da educação na modernização da sociedade. Tese (Doutorado em Educação). Universidade Estadual de Campinas/SP. 1999

MARTINS, Maria do Carmo. A BNCC e os Impactos na Educação Básica. In: Evento de Extensão do Programa de Formação Docente Continuada (PROFOR). Universidade Federal do Tocantins, UFT, Campus de Miracema, 26 nov. 2018 (Palestra).

PALMA FILHO, João Cardoso. Política Educacional Brasileira: educação brasileira numa década de incerteza (1990-2000) avanços e retrocessos. São Paulo: CTE Editora, 2005. (Série Políticas Públicas).
PIMENTA, Selma Garrido: ANASTASIOU, Léa das Graças Camargos.

Docência no Ensino Superior. 5. ed. São Paulo: Cortez, 2002

RIBEIRO, Maria Luisa Santos. História da Educação Brasileira: a organização escolar. 13. ed. Campinas/SP: Autores Associados, 1993. (Coleção Educação Contemporânea)

ROMANELLI, Otaíza de Oliveira. História da Educação no Brasil: 1930-1973. 31. ed. Petrópolis, RJ: Vozes, 2007

SAVIANI, Dermeval. A Pedagogia no Brasil: história e teoria. 2. ed. Campinas/ SP: Autores Associados, 2012. (Coleção Memória da Educação)

SILVA, Maria Cristina Fonseca da. Formação Docente em Arte: da formação das licenciaturas à formação continuada. Revista Digital Art., São Paulo, v. 11, n. 14, p. 01-28, dez. 2013. Disponivel em: http://WWW.revista.art.br/sitenumero-14/maria-cristina-rosa.pdf. Acesso em: 8 dez. 2017

SILVA, Maria Cristina Fonseca da. Desvelando caminhos: a formação docente em arte. In: XXVII Congresso Nacional da Federação de Arte/Educadores do Brasil (CONFAEB). Campo Grande/MS, 16 nov. 2017. (Mesa-redonda).

\section{Trânsitos Interdisciplinares em Artes}

Bárbara Tavares dos Santos, Liliane Scarpin S. Storniolo, Renata Patrícia da Silva (Organizadoras) 


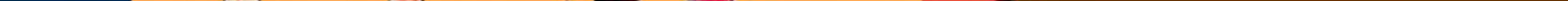




\section{Wamhã Kãtô Kri Isanãmze Wakõmẽkwa Wamhã̃: Ensaios de Uma Prática Intercultural e Pós-Colonial no Ensino das Artes}

Raquel Castilho Souza ${ }^{2}$ Karylleila dos Santos Andrade 3

17 Tradução do Akwẽ para o português: Escola Estadual Indígena Wakõmẽkwa

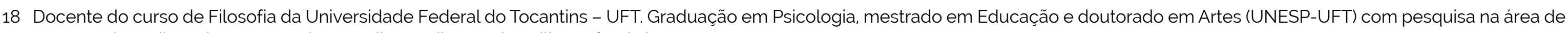
Artes e Educação. Palmas, Tocantins, Brasil; e-mail: raquelcastilho@uft.edu.br.

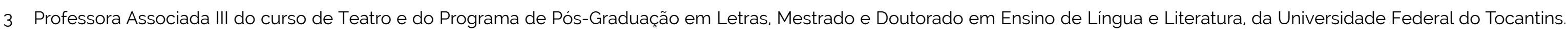

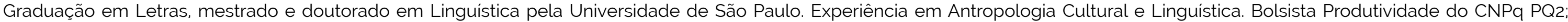
Palmas, Tocantins; e-mail: karylleila@gmail.com

\section{Trânsitos Interdisciplinares em Artes}

Bárbara Tavares dos Santos, Liliane Scarpin S. Storniolo, Renata Patrícia da Silva (Organizadoras) 
Da Sikrãiktõ ${ }^{4:}$

\section{A Escola Indígena e a Legislação Estadual}

No estado do Tocantins, a legislação para a educação indigena busca assegurar a oferta de um ensino fundamental regular com a utilização das línguas maternas e de programas que devem incluir comunidades, organizações e entidades. A Lei Estadual, n 1.038, de 22 de dezembro de 1998, esclarece a obrigação do Estado em relação à Educação para as sociedades indigenas, garantindo o bilinguismo para afirmação das culturas e línguas indígenas; preparação para compreensão e reflexão crítica da sua realidade sócio-histórica e da sociedade envolvida, bem como sobre a condição para sua autodeterminação; formação de professores indigenas; e viabilização de elaboração de materiais escritos pelos próprios indígenas que retratem seu universo sóciohistórico e cultural (TOCANTINS, 1998).
No entanto, diante da realidade atual, faltam políticas claras, por parte do governo estadual, para contratação de recursos humanos; formação inicial e continuada para atuarem em escolas indigenas e investimentos em infraestrutura escolar. Percebemos, durante a pesquisa de campo5, que a atuação dos professores fica comprometida por sentirem-se desmotivados em buscarem sem ajuda alguma, informações por meio de leituras e estudos coletivos na comunidade escolar para, por exemplo. produzir materiais didáticos. Com o momento atual político do país, bem como do Estado, tais circunstâncias se agravam, o que indica uma falta de compromisso com os grupos indigenas. Mas,

5 Esta pesquisa foi resultado de estudo, em nivel de doutoramento, cuja temática é a Educação Escolar Indigena Xerente. O lócus do estudo foi a Escola Estadual Indígena Wakõmẽkwa, localizada na Comunidade Riozinho Kakumhu, reserva Xerente, na região do Municipio de Tocantínia-TO. A investigação objetivou refletir sobre a concepção dos professores indigenas sobre o sentido do Ensino das Artes na escola Wakõmēkwa, a partir da perspectiva da Interculturalidade. O estudo realizado se constituiu em uma pesquisa social desenvolvida na perspectiva da etnografia multissituada, amparada na abordagem qualitativa.

4 Tradução do Akwẽ para o português: O encontro

Trânsitos Interdisciplinares em Artes Bárbara Tavares dos Santos, Liliane Scarpin S. Storniolo, Renata Patrícia da Silva (Organizadoras) 
ainda assim, com esse cenário crítico, os agentes educativos da Escola Indigena Wakõmẽkwa, localizada na Comunidade Riozinho Kakumhu, reserva Xerente, na região do Municipio de Tocantínia-TO, depositam suas esperanças por dias melhores. Para eles, a escola é a comunidade; o centro de aprendizagem da cultura; oportunidade de manterem a cultura deles viva, perpetuando-a entre as crianças e jovens Akwẽ. Os professores lidam, cotidianamente, com um indice muito alto de reprovação dos alunos indígenas que vão para as escolas nas cidades próximas, como: Tocantínia, Miracema e a capital, Palmas. Segundo relatos dos professores, os problemas são vários, dentre eles: a falta de domínio da segunda língua com relação às habilidades de leitura e escrita. Percebe-se que a escola também tem como foco preparar os estudantes indigenas para o mercado de trabalho. A partir disso, eles têm a oportunidade de ocupar espaços por meio de atividades remuneradas pelo Estado dentro da própria comunidade, como: técnico em enfermagem, enfermeiro, agente de saúde e professor, por exemplo.
Os Xerente se autodenominam Akwẽ e ocupam terras indigenas situadas à margem direita do Rio Tocantins, inicialmente com aproximadamente 183.542 hectares de área demarcada, segundo dados da Fundação Nacional de Saúde (FUNASA), de 2010. Araújo (2016) registra que a demarcação e homologação definitiva do território Xerente ocorreu em 1984 com uma subdivisão das terras indígenas localizadas no municipio de Tocantínia, estado do Tocantins, na margem direita do rio Tocantins, a 70 (setenta) quilômetros da capital do Estado, Palmas, sendo: a Terra Indígena Xerente e a Terra Indígena Funil. Hoje, essa área dos Xerentes envolve uma extensão territorial de 167.542 hectares. Araújo (2016) acrescenta que essa reserva está organizada em regiões, identificadas como: Porteira, Funil, Brupé, Brejo Comprido e Rio Sono. A população Xerente, desde os anos 90 (noventa), vem se mantendo resistentes, e um dos reflexos disso é o aumento significativo da população. Em 1999, registrou-se um número de 1.836 habitantes indígenas. Já em 2010, a população aumentou para 3.017 habitantes. E em

\section{Trânsitos Interdisciplinares em Artes}

Bárbara Tavares dos Santos, Liliane Scarpin S. Storniolo, Renata Patrícia da Silva (Organizadoras)

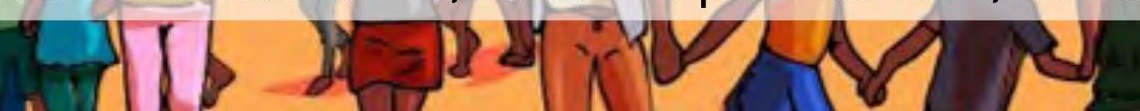


2016, verificaram-se registros de 3.814 indigenas, espalhados em 74 (setenta e quatro) comunidades (LIMA, 2016)

A extensão territorial desse povo teve mudanças com a criação da Usina Hidrelétrica de Lajeado6, que iniciou seu funcionamento em 2002 (VENÂNCIO; CHELOTII, 2016). Muitas áreas foram atingidas pela abertura das comportas da barragem e os povos indígenas sofreram com as consequências negativas. Vários impactos profundos e irreversiveis comprometeram as vidas dos mesmos e seu modo social e ambiental, com a expulsão de muitos indigenas e a diminuição do território destinado a agricultura. Outro exemplo refere-se ao fluxo migratório dos peixes que também foi reduzido, modificando o modo de vida de muitos indigenas (ARAÚJO, 2016; LIMA, 2016: WEWERING, 2012; VENÂNCIO; CHELOTTI, 2016)

6 As barragens da Usina localizam-se no rio Tocantins, abrangendo uma área total de $750 \mathrm{~km}^{2}$. Sua expansão afetou os municipios de Lajeado, Miracema do Tocantins, Palmas, Porto Nacional, Brejinho de Nazaré e Ipueiras (VENÂNCIO; CHELOTII, 2016).
Imagem 1: Mapa das comunidades indigenas Xerentes no ano de 1999.

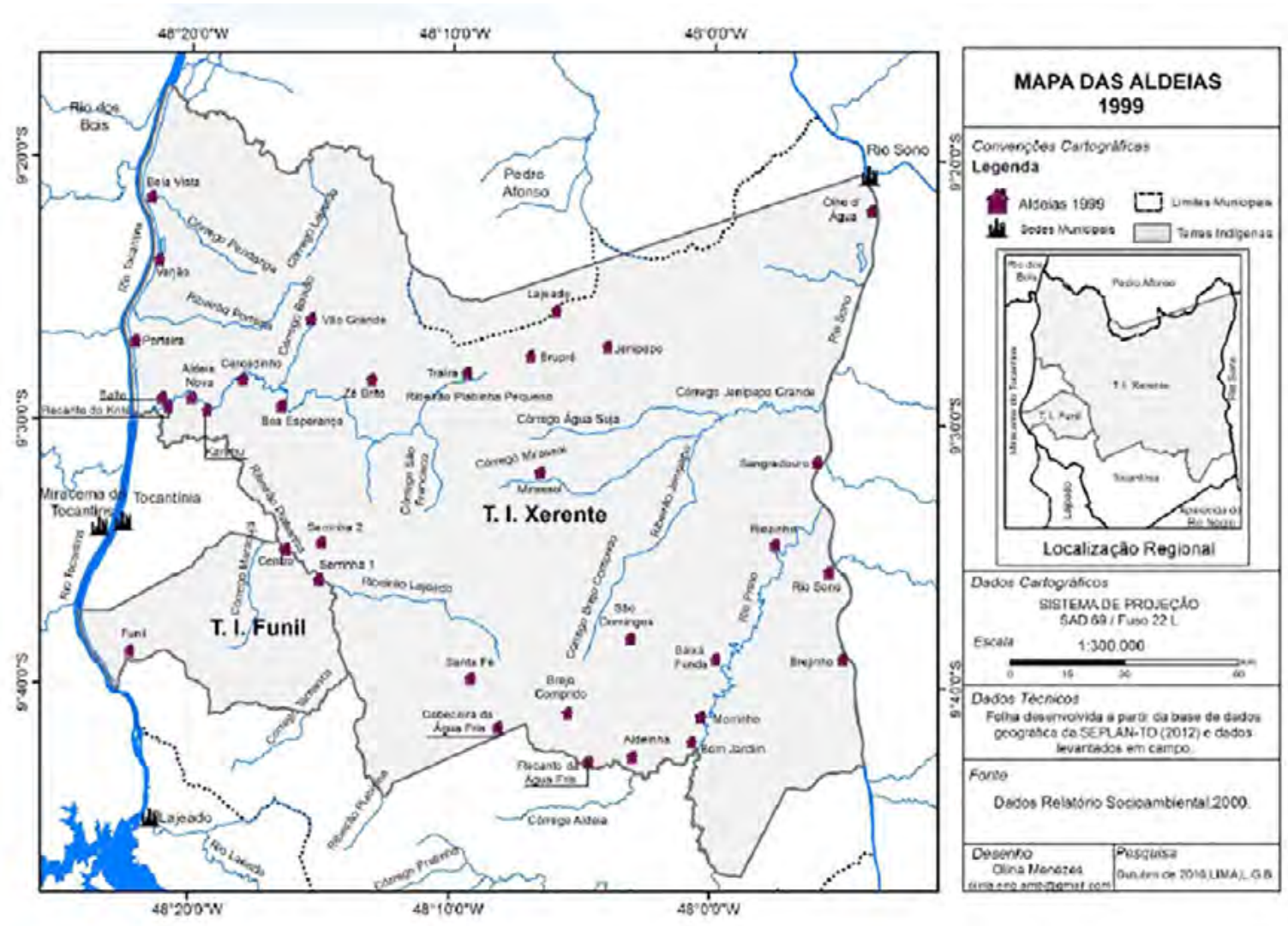

Fonte: Lima (2016, p. 171)

\section{Trânsitos Interdisciplinares em Artes}

Bárbara Tavares dos Santos, Liliane Scarpin S. Storniolo, Renata Patrícia da Silva (Organizadoras)

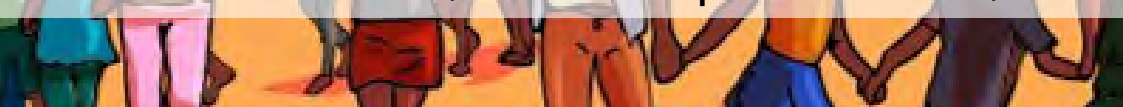


Na comunidade Riozinho, o trabalho com a agricultura está praticamente extinto por motivos financeiros e os jovens sentemse mais atraídos pelo que o centro urbano tem oferecido, diante do contato frequente com a cultura não indígena. Vale destacar que os indígenas, por pertencerem a uma cultura minoritária e marginalizada, podem não ter as mesmas oportunidades fora da escola da comunidade. Tais acontecimentos têm contribuido na desterritorialização das comunidades indígenas. Órgãos federais, como a FUNASA e a Fundação Nacional do Índio - FUNAl, têm perdido algumas atribuições, anteriormente designadas a elas em relação à política indígena, desde 2019, o que tem dificultado, ainda mais, a inserção no mercado de trabalho dos jovens indigenas dentro das comunidades.

Sobre a escola Wakõmēkwa, localizada na comunidade Riozinho, foco da pesquisa, a sua estrutura física é insuficiente para a demanda atendida; não tem manutenção e foi construida dentro de uma arquitetura de escola urbana, ignorando a cultura, traços e identidade indígenas.
Imagem 2: Sede atual da Escola Estadual Indígena Wakõmẽkwa

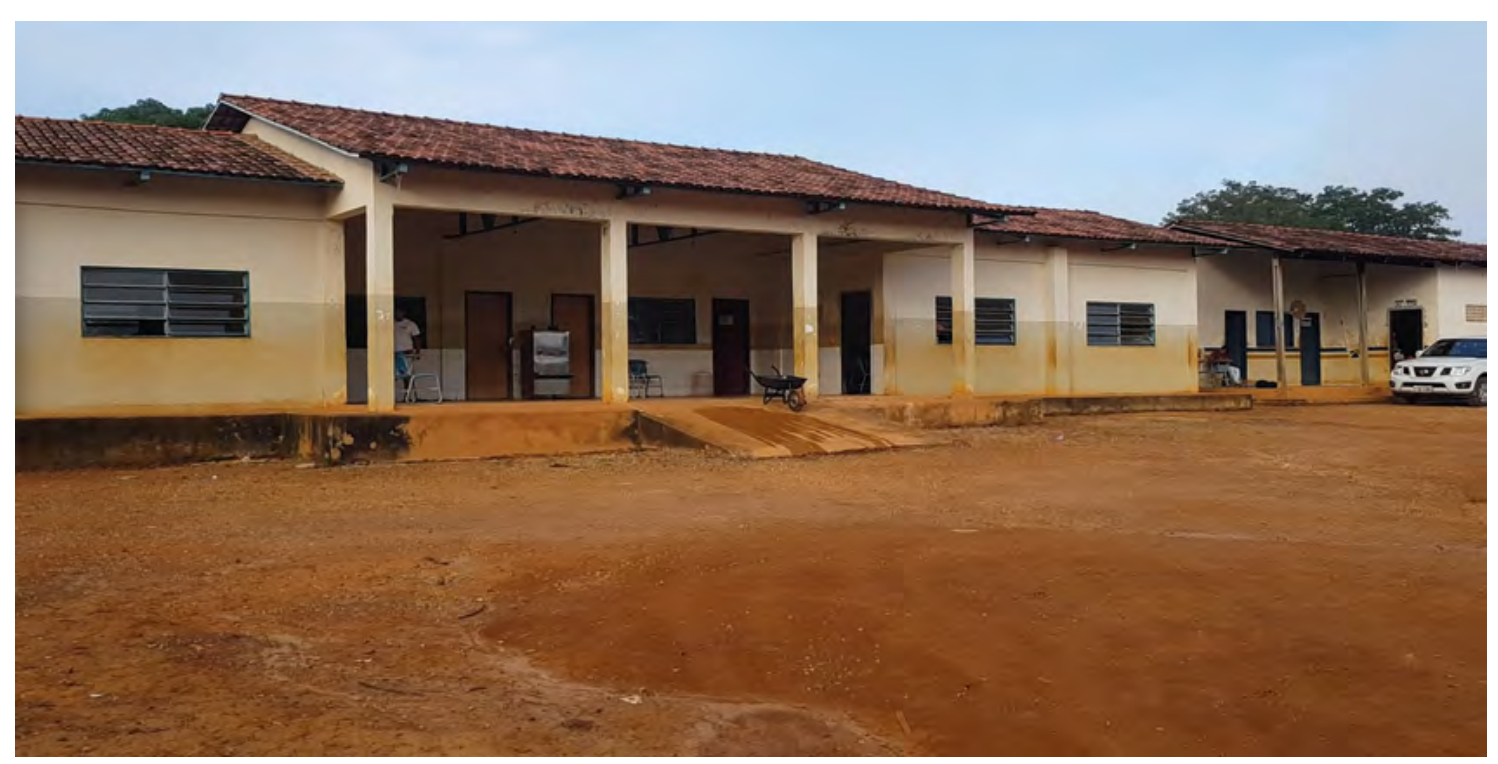

Fonte: Souza (2019, p. 24).

Atualmente a Escola Estadual Indigena Wakõmẽkwa tem 72 (setenta e dois) alunos, distribuidos nos três turnos (matutino, vespertino e noturno), atendendo há três Comunidades no total, sendo elas: Comunidade Riozinho, Sangradouro e Brejo Novo.

\section{Trânsitos Interdisciplinares em Artes}

Bárbara Tavares dos Santos, Liliane Scarpin S. Storniolo, Renata Patrícia da Silva (Organizadoras) 
A escola fornece alimentos todos os dias, sendo a maioria deles industrializados ${ }^{7}$ e frutas. A evasão é mais comum na Educação de Jovens e Adultos - EJA. O livro didático adotado na escola é o disponibilizado pela SEDUC - Secretaria de Estado da Educação, Juventude e Esportes e está redigido em língua portuguesa. Os alunos não recebem material didático na língua Akwẽ para uso. Foram identificados, na escola, como material em Akwẽ: um dicionário Escolar Xerente-Português/Português-Xerente, de 1994"; uma apostila intitulada "Escrita Xerente - A Sílaba" para professores

7 A comunidade escolar foi questionada quando a esse fator: oferecer alimentos industrializados aos alunos e colaboradores. Segundo os professores e gestores, isso acontece por falta de organização social da comunidade. Atualmente não fazem plantação de alimentos, com exceção a mandioca que é para consumo exclusivo das famílias. Faltam recursos financeiros e estruturais para tal atividade e a DRE - Diretoria Regional de Ensino de Miracema que administra financeiramente e supervisiona as atividades da unidade, não consegue fornecedores na região, principalmente pela dificuldade de acesso à escola.

8 Dicionário Escolar: Xerente - Português; Português - Xerente / Org. por Wanda Braidotti Krieger e Guenther Krieger. Rio de Janeiro: Junta de Missões Nacionais da Convenção Batista Brasileira, 1994, 118 p
Xerente9; e outra apostila como o título: Akwẽ Xerente Nĩm Hêsuka - Rowahtuzem Nnãkrta Pibumã̃ ${ }^{10}$ utilizadas frequentemente pelos professores de artes para ministrar as aulas.

Uma "Possivel" Prática Intercultural e Pós-Colonial no Ensino das Artes na Escola Estadual Indígena Wakõmẽkwa

Segundo Fleuri (2003), a escola indigena intercultural, em suas práticas, deve incluir o caráter da sua cultura tradicional,

9 Essa apostila foi preparada por Rinaldo Martins, em Maio de 2000, na cidade de Miracema do Tocantins-TO. Miracema do Tocantins é vizinha dos municipios de Miranorte, Tocantínia e Barrolândia. Fica localizada a $68 \mathrm{~km}$ a Norte-Oeste de Palmas, capital do Tocantins. A distância entre Miracema e Tocantínia, cidade que dá acesso a comunidade Riozinho Kakumhu é de $2,3 \mathrm{~km}$. E de Tocantínia a Comunidade Riozinho Kakumhu percorre-se um trecho de $68 \mathrm{~km}$ de estrada de chão. Fonte: <http://www.cidade-brasil.com.br/municipiomiracema-do-tocantins.html>. Acesso em: 20 set. 2017

10 A expressão traduz o termo "Cartilha Akwẽ Xerente - Séries Iniciais". Esse material foi confeccionado por um grupo de indígenas Xerente (Wilson Suwate, Claúdio Kumrĩzdazê, Viturino Mãrawẽ. Bonfim Sizdazê, Vilmar Kmõmse, Valnice kazudi e Manuel Sirnãrẽ) para alfabetização em Akwẽ com elementos da cultura e reproduzida em Tocantínia em 2000 com impressão aparentemente doméstica.

\section{Trânsitos Interdisciplinares em Artes}

Bárbara Tavares dos Santos, Liliane Scarpin S. Storniolo, Renata Patrícia da Silva (Organizadoras)

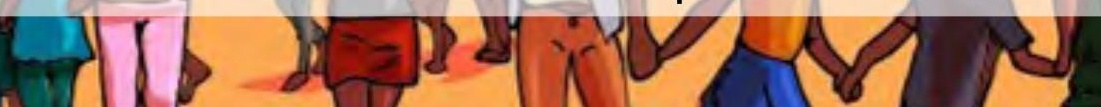


assim como das outras culturas, principalmente em suas ações pedagógicas dando sentido à história e tradição do seu povo, reafirmando o anseio dos professores indigenas. Dessa forma, é possivel que haja uma valorização dos conhecimentos e pedagogias dos povos indigenas, das línguas maternas, da interculturalidade; primando pela autonomia escolar, inclusive colaborando na elaboração dos currículos oficiais e calendários (HENRIQUES et al., 2007). Assim, deve-se refletir sobre a cultura tradicional no espaço escolar, que para a comunidade escolar indígena é conhecimento. história, mitos, rituais, que podem ser vividos pela prática e oralidade. contemplando o modo de ser indígena.

Alguns questionamentos surgem dentre da própria comunidade indigena: a cultura está se perdendo ou apenas está sendo esquecida? Para eles, a escola deve se apropriar dessas questões e refletir sobre elas. Refletir sobre a cultura é reconhecer a diversidade dos povos, das nações, das sociedades e dos grupos que são compostos por diferentes agentes sociais. Toda comunidade cultural tem sua história particular, que é reflexo de sua própria cultura, mesmo que o grupo se relacione com outras culturas (SANTOS, 1994). Um dos professores indígenas ${ }^{11}$ destaca que:

A escola indigena deve ser diferenciada, mas que ela é diferenciada somente pela cultura, práticas culturais e a lingua, porque o conhecimento é universal e o sistema não indigena está na escola indigena. E a diferença deve somar a outra diferença.

Esse relato questiona o lugar da escola indigena, cujos processos devem ser desenvolvidos, no nosso entendimento, dentro de uma perspectiva da interculturalidade crítica, ultrapassando as questões postas nos curriculos formais e na legislação. Essa prática pode ser vivenciada do mesmo modo que eles veem a escola com um sentimento de pertencimento, como uma extensão da comunidade. Porém, essa extensão tem que ser

11 Por orientação do Comitê de ética, foi optado por não apresentar os nomes dos participantes dessa pesquisa, para os resguardar, assegurando sigilo.

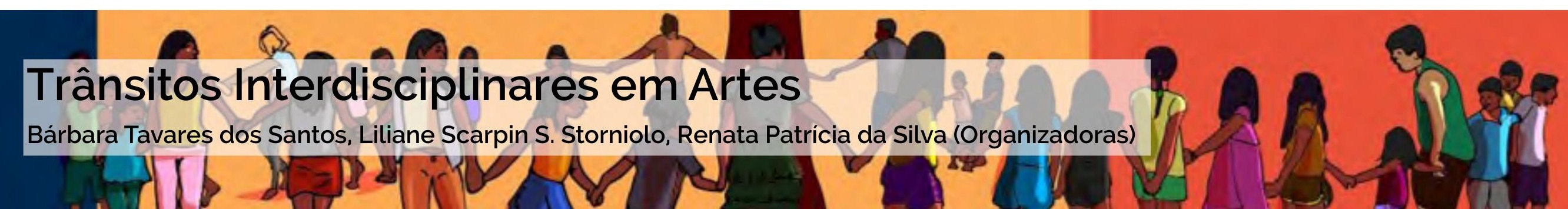


cultural e não apenas uma estrutura física com oferta de ensino, porque isso seria insuficiente para amenizar as dificuldades dos indigenas irem a uma escola colonizada ${ }^{12}$. Percebe-se que a escola colonizada está na comunidade e na escola indigena. O currículo formal da escola indígena, o regimento escolar, atualmente é igual ao das outras escolas urbanas, dentre outros fatores.

Toda essa discussão nos remete ao que Durkheim (1999:1965) sinaliza quanto ao modo tradicional dos povos nativos se educarem, que é pela coletividade, pela solidariedade mecânica. A comunidade indigena pode desenvolver suas estruturas e trabalho pelo consenso coletivo. Desse modo, suas tradições e culturas poderão ser respeitadas, o que implica em ação conjunta, caracterizada pela unidade (DURKHEIM, 1999; 1965). Desse modo, a escola pertence, na visão deles, à comunidade. E isso será

12 Escola desenvolvida a partir de um sistema de dominação, da denominação e classificação desenvolvido nas relações de poder pelo sistema capitalista, com estrutura e currículo imposto desconsiderando a realidade especifica de cada unidade escolar. possivel na escola com uma educação exercida pelas gerações adultas sobre as novas gerações. No entanto, atualmente, nas escolas indigenas, em função do desenvolvimento do capitalismo, a educação vem sendo desenvolvida a partir dos conceitos de solidariedade orgânica, que consequentemente, tem contribuído na descaracterização da própria cultura no seu espaço de origem.

As aulas de Artes observadas, foram todas ministradas em Akwẽ. com conteúdos indígenas. Em algumas aulas, identificou-se um plano de aula registrado no material do professor, outras vezes, não. No período de observação, que se transcorreu durante o ano de 2018, evidenciou-se que em nenhuma segunda-feira as aulas de Artes aconteceram nas três turmas regularmente, por motivos diversos: problemas de saúde do professor; falta do professor; substituição dos conteúdos de Artes por outras disciplinas

O Ensino das Artes não pode ser limitado pelo tempo ou pelas questões técnicas, porque se corre o risco dela se tornar mais fragilizada do que já é nos ambientes educacionais. Essa disciplina deve ser vista como um caminho para a valorização e revitalização

\section{Trânsitos Interdisciplinares em Artes}

Bárbara Tavares dos Santos, Liliane Scarpin S. Storniolo, Renata Patrícia da Silva (Organizadoras)

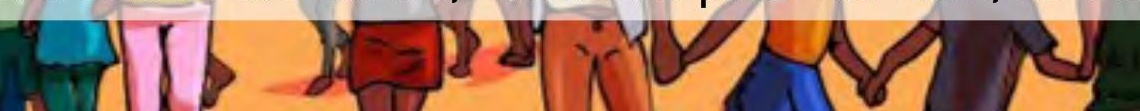


das culturas (PENTEADO; CARDOSO JUNIOR, 2014). Os professores da Escola Indigena Wakõmẽkwa percebem a importância do Ensino das Artes, porque ela tem relação direta com a cultura Akwẽ.

No currículo, a transdisciplinaridade ${ }^{13}$ deve fazer-se presente com enfoques pluralistas do conhecimento. Os conteúdos universais e específicos da cultura precisam ser contemplados, mas não da maneira que um sobreponha ao outro como superior. 0 ensino da tradição, da cultura, da língua nativa devem ser primados, mas não dividindo os saberes, e sim os complementando como formas de conhecimento e fortalecendo as multiplicidades culturais. Esse currículo deveria ser aquele construido na perspectiva póscolonial: multicultural, envolvendo as culturas silenciadas, de modo a promover uma relação ao contexto da reterritorialização dessas culturas (SILVA, 2015: SANTOMÉ 1995: SANTOS, 2010b).

13 Termo que caracteriza uma prática de ensino plural com um olhar múltiplo, desenvolvendo e relacionando diversas formas de conhecimento a partir das multiplicidades culturais.
Desse modo, deve-se romper com os processos de homogeneização que ocultam as diferenças. E no caso da Arte, seu curriculo deve ser aquele que, segundo Penteado e Cardoso Junior (2014, p. 231), promova o "fazer/pensar Arte como parte da elaboração da existência e das reivindicações de si, no cruzamento dos fluxos da Arte, cultura e filosofia." Ou seja, desconstruir os sentidos projetados pelos documentos oficiais nos currículos escolares para a educação indigena.

Para as turmas do $1^{\circ}$ e $2^{\circ}$ anos, as aulas de Artes aconteceram por meio de atividades de desenho (Imagem 03). Por vezes, as atividades pareciam não corresponder ao nível de aprendizagem dos alunos. Aconteceu de um professor ter que pensar em outro modo de ministrar o conteúdo, pelo fato de algumas crianças não conseguirem desenvolver, inicialmente, as atividades propostas. Em uma das aulas, identificou-se o uso de um material em Akwẽ, que se trata de uma apostila dos saberes, língua e Arte indígena - identificado como Akwẽ Xerente Nĩm Hêsuka -

\section{Trânsitos Interdisciplinares em Artes}

Bárbara Tavares dos Santos, Liliane Scarpin S. Storniolo, Renata Patrícia da Silva (Organizadoras)

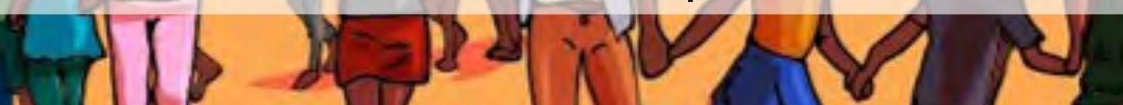


Rowahtuzem nnãktra pibumã. O material foi utilizado ora na aula de Artes, ora na aula de redação.

Imagem 3: Aula de Artes na Escola Estadual Indígena Wakõmẽkwa.

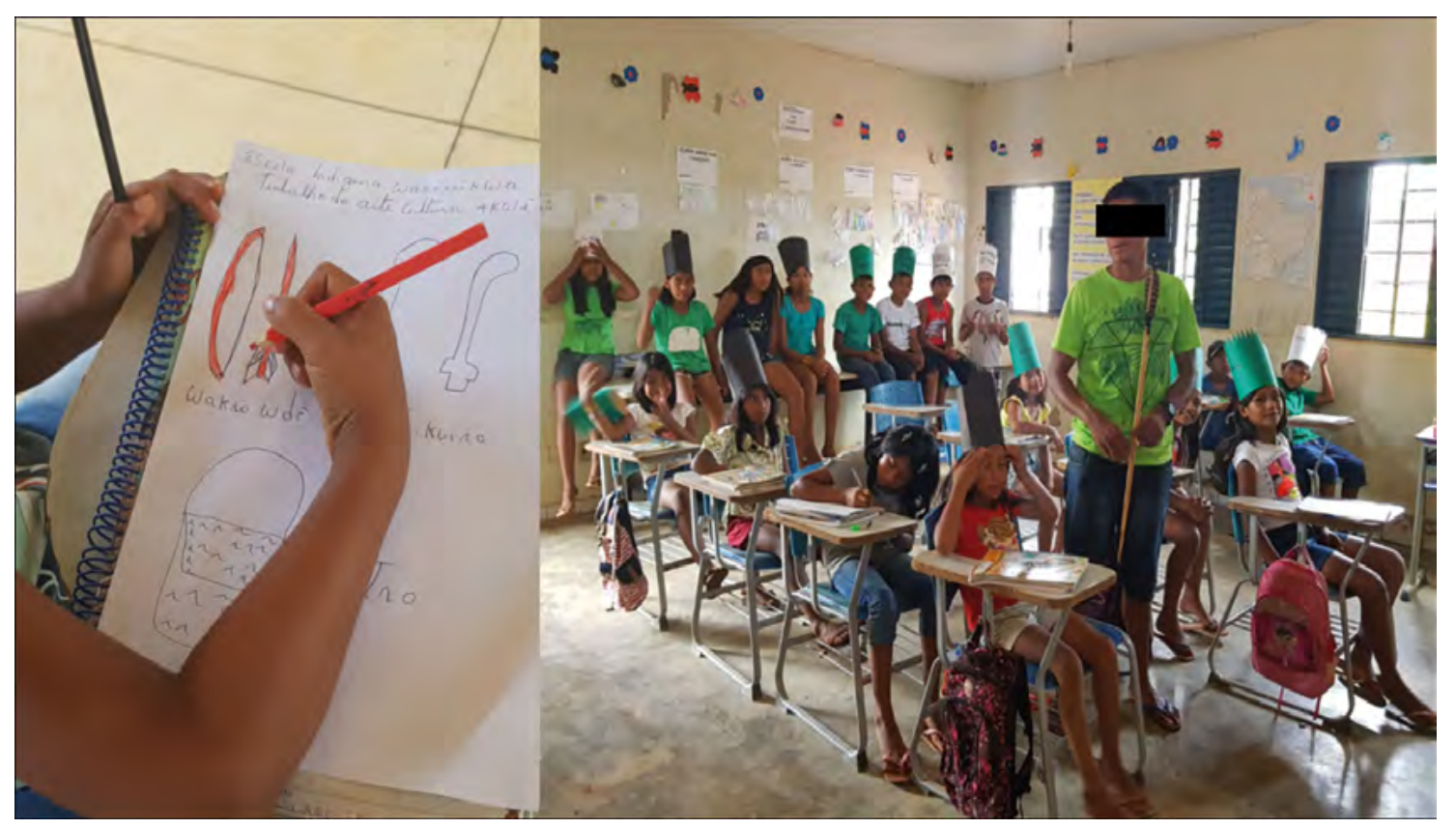

Fonte: Souza (2019, p. 201).
Para as turmas do $3^{\mathrm{a}}$ ao $5^{\circ}$ anos, as aulas observadas, como ilustra a Imagem 3, foram todas práticas. Foi observado o uso de outros materiais didáticos que envolvem temáticas da cultura Xerente, além do material disponibilizado pela SEDUC para o Ensino das Artes e de outras disciplinas, como o português.

Os professores, ao serem questionados sobre a finalidade da Arte na escola, evidenciaram justamente o reconhecimento do quanto ela é importante. Durante as atividades desenvolvidas, eles descreveram para que a Arte serve na escola:

[... viver e compreender a realidade da nossa cultura, cultura dos outros povos, intender a dimensão da cultura em geral, dividindo a forma de viver e olhar o mundo diferente.

l... identificação na escola, como os povos se dividem dentro da cultura, como se respeita na divisão dos clãs, e como é a cultura dos outros povos.

l... garantir a identidade e melhora aprendizagem.

[... sabemos que Arte na escola é uma disciplina muito importante ela traz consigo a emoção da pessoa se sentir feliz.
Trânsitos Interdisciplinares em Artes

Bárbara Tavares dos Santos, Liliane Scarpin S. Storniolo, Renata Patrícia da Silva (Organizadoras) mis xisting 
Por esses relatos, percebemos o sentimento de pertencimento que eles têm em relação à escola, falaram de maneira positiva da cultura pelo Ensino das Artes. Discutir a Arte indígena Akwẽ seria, para os professores, o meio de "representar uma identificação cultural Xerente," bem como a oportunidade de "vivenciar a cultura no dia a dia, dança, cântico e Artesanato que está no meio de nós."

Desse modo, a Arte indigena Akwẽ torna-se uma atividade cultural reconhecida na festa, nos cantos, rituais, nas pinturas corporais, no Artesanato e também na escola. Ela pode ser um dos caminhos para despertar o conhecimento dos alunos em relação à cultura indígena Akwẽ. Consequentemente, a vivência dessa cultura, no ponto de vista dos professores, não pode se resumir apenas na disciplina de Artes. Ela deve fazer parte do ensino das demais disciplinas, por meio da criação, construção e reflexão. Logo, a Arte indigena Akwẽ teria um olhar mais afetivo e significativo na escola e na vida da comunidade escolar. Como resultado, seriam possiveis ações interculturais por meio da interdisciplinaridade nas atividades escolares das comunidades indigenas.

A Base Nacional Comum Curricular - BNCC (MEC, 2017) discute a Arte inserida numa dimensão educativa, como aquela que pode contribuir para um diálogo intercultural, pluriétnico e plurilíngue, a partir da experiência artística como prática social, considerando: a diversidade cultural e étnica existente no país, com suas respectivas línguas de origem. Nesse sentido, os alunos em suas atividades deveriam desenvolver uma experiência artística, sendo os protagonistas e criadores de um trabalho que requer uma relação entre a Arte e cultura. Nesse processo, a criação, a critica, a estesia, a fruição e a reflexão devem se fazer presentes e interagir a partir da experiência artística que o aluno está vivenciando no ambiente escolar (MEC, 2017). E essa é a aspiração dos professores ao falarem da Arte na escola, que é associada e conceituada a partir da cultura deles.

\section{Trânsitos Interdisciplinares em Artes \\ Bárbara Tavares dos Santos, Liliane Scarpin S. Storniolo, Renata Patrícia da Silva (Organizadoras)

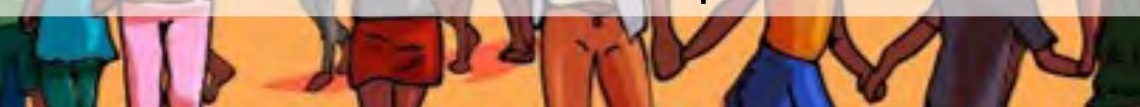


Imagem 4: Cultura e Arte Akwẽ - Professores - Escola Indígena Wakõmẽkwa.

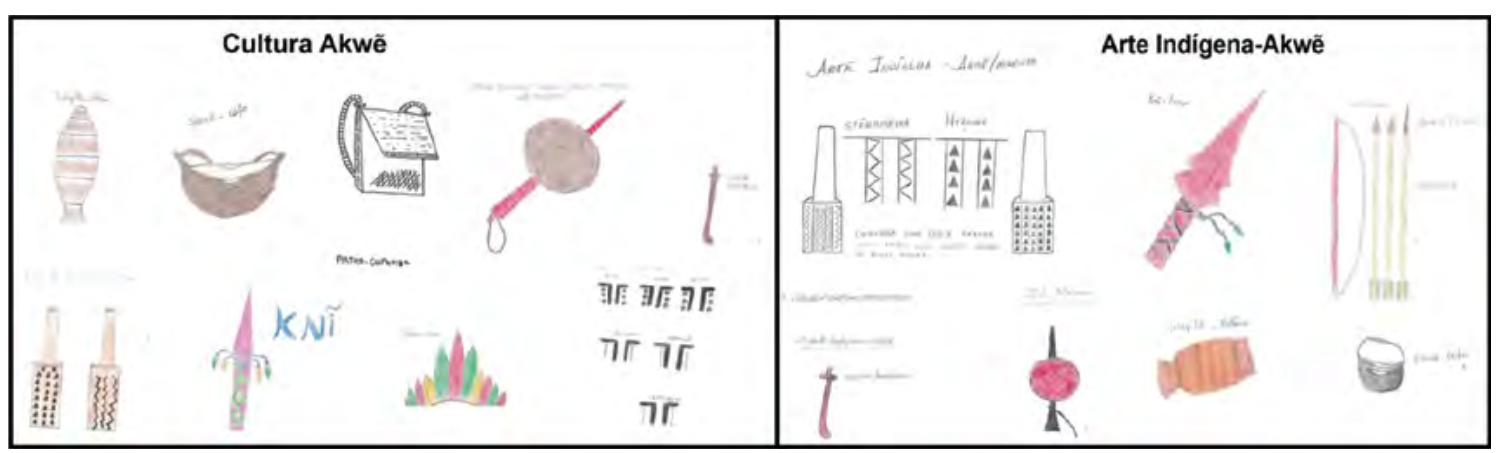

Fonte: Souza (2019, p. 203)

É importante frisar que o currículo do estado do Tocantins está atendendo ao especificado nas bases legais em nivel federal, como o descrito no Referencial Curricular Nacional para a Educação Indígena - RCNEI (MEC, 1998). As disciplinas, Língua Indigena, Artes e Cultura e História e Cultura Indigenas, estão previstas e são desenvolvidas regularmente nas atividades na escola Wakõmẽkwa. Os professores, ao seu modo, e com suas dificuldades pedagógicas, têm mantido presente a sua cultura no ambiente escolar na tentativa de preservar as tradições indigenas. Muniz (2017) aponta que elas são as disciplinas que mais contribuirão para o desenvolvimento da perspectiva intercultural no currículo indígena. Assim, as disciplinas, Lingua Indigena, Artes e Cultura e História e Cultura Indigenas deveriam ser desenvolvidas promovendo uma reflexão crítica e não apenas no nível de execução, como se tem observado na rotina escolar.

Desse modo, o currículo de Arte, segundo Barbosa (2013), deve ser aquele que instigue o aluno a perceber e refletir suas reações estéticas ao contato com a Arte, diante das diversas manifestações da Arte no mundo. Mas para isso, ele precisa ser aberto e flexivel e não uma descrição de conteúdo e de tudo que o professor deve fazer ao ensinar a Arte. Ademais, é preciso construir e viver o currículo de acordo com a realidade local, contemplando outros saberes, considerando o conhecimento de outras culturas, mas não como a mais importante. Dessa maneira, superar a visão colonizadora e promover uma relação dialética entre a cultura universal e a particular, fazendo-se presente no
Trânsitos Interdisciplinares em Artes

Bárbara Tavares dos Santos, Liliane Scarpin S. Storniolo, Renata Patrícia da Silva (Organizadoras) 
ambiente escolar indigena o princípio da igualdade e da diferença. Ai sim, estariamos caminhando com ações que podem colaborar na efetivação de diálogos interculturais críticos, superando os falsos universalismos, o que não é impossivel (SANTOS, 2010b).

Silva (2015), em relação ao curriculo, promove uma reflexão interessante. Ele destaca, assim como muitos autores já citados nesse texto, que o discurso curricular posto nos documentos está vinculado ao que é tradicional, mas com reflexo de um processo industrial e administrativo, que se preocupa com a questão técnica e formação de trabalho, na lógica mercantilista, individualista e da competição. Como aquela que atualmente está presente nas comunidades indigenas e que Durkheim (1999) define de solidariedade orgânica, o que tem contribuído para a descaracterização e desterritorialização da própria cultura no seu espaço de origem. Ou seja, o sistema coloca num ambiente em que se valorize a solidariedade coletiva, uma lógica individualista mercantilista por meio do currículo escolar.
O currículo nas escolas indígenas, assim como nas não indigenas, tem sido construido por um processo racional que vislumbra resultados educacionais baseados em metas e que devem ser mensurados. Ele é transmitido por meio de códigos da cultura dominante. E para aqueles que não pertencem a essa classe. como os indigenas, esse código torna-se de dificil compreensão, como se estivesse numa língua estrangeira. Consequentemente, para os povos indigenas esse currículo se torna indiferente e bizarro quando aplicado na sua realidade cultural. Isso tem contribuido no fracasso escolar, nos índices de evasão, uma vez que sua cultura nativa está em desprestígio (SILVA, 2015).

Lagrou (2013) destaca que Arte indígena, ao ser trabalhada num contexto educacional, deve considerar as especificidades de produção de cada povo, as suas identidades. Cada povo tem a sua tradição que o caracteriza como tal, com conhecimentos complexos em relação ao mundo, à natureza e suas relações entre tudo isso. E esses conhecimentos não podem ser esquecidos ao se

\section{Trânsitos Interdisciplinares em Artes}

Bárbara Tavares dos Santos, Liliane Scarpin S. Storniolo, Renata Patrícia da Silva (Organizadoras) 
promover o Ensino das Artes numa escola indígena. O Referencial curricular nacional para a educação infantil - RCNEI (MEC, 1998), afirma a reflexão de Lagrou (2013), quando propõe a inserção da Arte como disciplina na escola indígena. Nesse processo, deve estimular o respeito, a multietnicidade, a pluralidade e a diversidade e não a normatização do Ensino das Artes como está nas escolas. E a Arte inserida na escola como disciplina, infelizmente, não tem como não ser normatizada. Há uma pedagogização por meio de uma imposição curricular. Isso é imposto por um sistema que conduz a educação desde o início da sua história. Só mudam os discursos, a forma de apresentação, mas o modelo é o mesmo para atender a classe dominante, ao conhecimento que é visto como universal por essa mesma classe.

O RCNEl reflete sobre o Ensino das Artes por meio de uma integração curricular, envolvendo as demais disciplinas. Seus conteúdos deverão contemplar a vivência dos povos indígenas. Assim, o sentimento de pertencerem a determinado povo poderá ser evidenciado e trabalhado, contribuindo para a construção de identidades (MEC, 1998).
Como vimos na Lei de Diretrizes e Bases - LDB, $N^{\circ}$ 9.394/96, o Ensino das Artes encontra-se como componente obrigatório da Educação Básica o qual deve considerar os conhecimentos regionais para seu desenvolvimento no ambiente escolar (BRASIL, 2013). Na BNCC, a disciplina de Artes vem como componente da linguagem e deve abranger todas as linguagens artísticas: artes visuais, dança, música e teatro. Suas ações devem propiciar a troca entre culturas e favorecer o reconhecimento e diferenças entre elas (MEC, 2017). As aulas na escola Wakõmẽkwa se sobrepõem à linguagem das Artes visuais e isso tem relação com a cosmovisão e cultura dos indígenas, como a pintura corporal, sentida pelo grupo como Arte. A disciplina de Artes, sendo vista e trabalhada em uma dimensão educativa, pode contribuir em um diálogo intercultural, pluriétnico e plurilingue, a partir da experiência artística como prática social, desde que seja trabalhada em uma perspectiva crítica e não apenas demonstrativa. Desde que não seja normatizada por um curriculo racionalista, industrial e administrativo (SILVA, 2015). E isso é uma realidade que, em princípio, pela legalidade, é difícil de intervir, mas não impossível. A luta dos

\section{Trânsitos Interdisciplinares em Artes}

Bárbara Tavares dos Santos, Liliane Scarpin S. Storniolo, Renata Patrícia da Silva (Organizadoras)

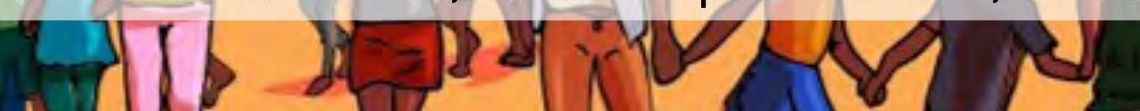


indigenas caminha em direção a essa conquista, principalmente quando reivindicam seus direitos quanto à autonomia na escola. Percebemos situações como a manifestação da comunidade contra o processo seletivo simplificado do diretor escolar, ou ainda, resistência à utilização do material didático disponibilizado pelo Estado, buscando outros recursos didáticos para ministrarem aulas, como: apostilas produzidas pelo povo indigena.

A SEDUC vem buscando atender o especificado nos documentos oficiais, estabelecendo diretrizes e normas para regimentar a Educação indigena no estado do Tocantins, obedecendo à Lei 9.394/96 as escolas no Estado deverão ser especificas, bilingues e interculturais (TOCANTINS, 2007). Em 2013, a SEDUC, em parceria com o Conselho de Educação Escolar Indigena do Tocantins - CEEI-TO, elaborou a primeira Proposta Pedagógica da Educação Escolar Indigena do estado do Tocantins - PPEEI-TO. O Ensino das Artes está contemplado nas disciplinas de Língua Indígena, Arte e Cultura e História e Cultura Indígenas, as quais devem ser elaboradas como o objetivo de manterem presentes a cultura dos indigenas no ambiente escolar, servindo de instrumento para a preservação cultural das tradições indigenas.

Assim, os alunos, em atividades que contemplem experiências artísticas, devem ser os protagonistas e os criadores de um trabalho que requer um processo entre a Arte e cultura, de modo que, nas suas experiências com a comunidade e com a escola, tais conhecimentos façam sentido em suas vidas e práticas diárias.

Em nenhuma aula de Artes, verificou-se o uso do livro didático, como podemos ver na Imagem 5, que nos mostra capas dos livros de Artes da Escola Indígena Wakõmẽkwa (10 a $5^{\circ}$ ano)..14 Esse material é fornecido pela SEDUC para a respectiva disciplina.

14 Essa Imagem está apresentada para fins de ilustração. O livro do $1^{\circ}, 2^{\circ}$ e $3^{\circ}$ anos do Ensino Fundamental é da coleção "Campo aberto", de Rosane Acedo Vieira, de 2014, Editora Global. Já o livro do 4 e $5^{\circ}$ anos contempla as disciplinas de História, Geografia, Arte e Cultura, da Coleção Tempo de Aprender - Região Norte, de Márca Cristina Hipólide e Mirian Gaspar.

\section{Trânsitos Interdisciplinares em Artes}

Bárbara Tavares dos Santos, Liliane Scarpin S. Storniolo, Renata Patrícia da Silva (Organizadoras) 
Um dos professores justificou a opção por não utilizá-lo, porque, segundo ele, o conteúdo das Artes que deve ser trabalhado em sala de aula está na memória deles e na oralidade, e isso precisa ser ensinado às crianças. Os professores, ao seu modo, estão buscando outros recursos que aproximam mais da cultura, como o uso de apostilas e de elementos da natureza e da cultura, como a flecha. No material da SEDUC, não foram identificados conteúdos culturais e artísticos específicos do Povo Xerente. Além disso, aborda-se muito pouco em relação às tradições indigenas. Diante dessas evidências, a disciplina de Artes tem sido ainda, apresentada pelas políticas públicas da mesma maneira que é para uma escola urbana e capitalista. Segundo Moreira e Candau (2014), a disciplina ainda tem sido trabalhada de modo formal, abstrata. Os conceitos disponibilizados em seus conteúdos, nos materiais disponibilizados pela SEDUC não têm relação com a vida prática de quem está no processo de formação escolar na comunidade indígena.

De modo geral, percebe-se que o conceito de Arte, para os professores indígenas da escola pesquisada, está relacionado

\section{Trânsitos Interdisciplinares em Artes}

Bárbara Tavares dos Santos, Liliane Scarpin S. Storniolo, Renata Patrícia da Silva (Organizadoras)

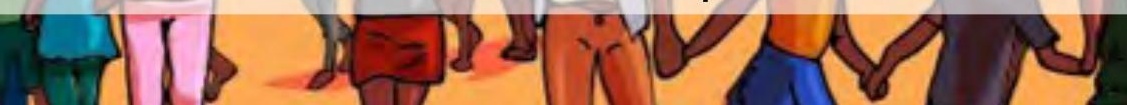


ao conceito de cultura tradicional indígena, com o fazer daquele povo que tem relação com a história, mitos, rituais, conhecimento, alimentação, cosmologia, vínculo com a natureza. Desse modo, pelo Ensino das Artes pode-se refletir e vivenciar a cultura Akwẽ no momento presente. Todas as turmas usaram objetos específicos na disciplina, mesmo que por figura ou desenho, assim como os professores nas rodas de conversa. Outro fator que se observou foi a ausência de uma interação lúdica e afetiva no decorrer da aula entre professor e alunos. Mas, há um respeito dos alunos em relação ao professor, mantendo a disciplina em sala de aula.

Chamou-nos a atenção o fato das identificações e escritas espalhadas pela escola estarem em maior número na lingua materna, considerando que querem manter a cultura, principalmente na educação daquele povo, mas as dificuldades pedagógicas e estruturais os limitam em suas ações. As turmas são multisseriadas, o que aumenta as dificuldades das questões metodológicas. A escola, para funcionar, precisa ter uma quantidade mínima de alunos por turma. A gerência de
Desenvolvimento da Educação Indigena do Tocantins informounos que a legislação educacional prevê em torno de 15 (quinze) alunos no mínimo e no máximo 30 (trinta) a 40 (quarenta) alunos. E as turmas são multisseriadas porque geralmente o número de alunos é insuficiente para formarem turmas seriadas. Porém, o CEEI-TO tem solicitado que a junção seja menos nas turmas em relação ao Ensino Fundamental - primeira fase, com a seguinte divisão: $1^{\circ}$ ao $3^{\circ}$ ano numa turma e em outra do $4^{\circ}$ e $5^{\circ}$ ano. E que no ensino médio não haja turmas multisseriadas. Isso ainda está em revisão com a SEDUC, porque há ainda um segundo entrave que faz com que as turmas sejam multisseriadas: o espaço físico geralmente não é satisfatório. E isso é um limitador na Escola Indigena Wakõmẽkwa, que possui apenas três salas de aula. A maioria das escolas indigenas tem a limitação de infraestrutura. Tanto a SEDUC quanto o CEEI-TO estão procurando identificar meios e alternativas para atender a Resolução n 2, de 28 de Abril de 2008, que estabelece diretrizes complementares, normas e principios para o desenvolvimento de políticas

\section{Trânsitos Interdisciplinares em Artes}

Bárbara Tavares dos Santos, Liliane Scarpin S. Storniolo, Renata Patrícia da Silva (Organizadoras)

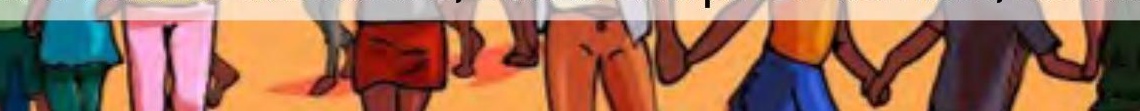


públicas de atendimento da Educação Básica do Campo, sendo de responsabilidade dos Entes Federados e regulamentada e oferecida pelos Estados, pelo Distrito Federal e pelos Municípios, nos respectivos âmbitos de atuação prioritária (MEC, 2008).

Percebeu-se, também, que, atualmente, existe um conflito na comunidade e isso tem afetado a rotina da escola desde o final do ano de 2017. Tanto é que a escola sofreu mais algumas mudanças em 2018: uma das comunidades que a escola atendia não está mais no grupo e criou outra escola; houve também a mudança de gestão na Escola Estadual Indígena Wakõmẽkwa. E no ano de 2019, mais uma comunidade se desmembrou da escola, inicialmente com a intenção de fundar outra escola na comunidade. por confiarem em promessas políticas. Mas, não conseguiram e os alunos, segundo informações, foram matriculados em outra escola na comunidade. Atualmente, a escola Wakõmẽkwa atende a três comunidades: Riozinho, Sangradouro e Brejo Novo. Segundo Bourdieu (1989), isso ocorre porque, mesmo estando em um campo em que as pessoas, aparentemente, têm os mesmos objetivos e valores, pode-se encontrar nele relações de força e de dominação, que podem refletir em um jogo de interesses que não corresponde a todos que estão no lugar. O campo é reflexo de lutas dos agentes, grupos e instituições.

Para Bourdieu (1989), os agentes podem produzir o capital para conservar ou conquistar posições por meio da autoridade que se dá ao indicar, pelo uso do poder, regras, que tem a intenção de dividir o capital do campo. É isso que tem acontecido, segundo alguns membros da comunidade por dois motivos: influência externa de políticos e conflitos internos entre as comunidades da reserva Xerente. A gerência de desenvolvimento da Educação Indigena no estado do Tocantins omite-se diante desses conflitos por entender que é uma questão de política e organização interna das comunidades indigenas. A legislação prevê justamente isso: a organização e o funcionamento das escolas do campo deverão ser respeitados, considerando as diferenças entre as populações atendidas quanto à sua atividade econômica, seu estilo de vida, sua cultura e suas tradições (MEC, 2008).

\section{Trânsitos Interdisciplinares em Artes}

Bárbara Tavares dos Santos, Liliane Scarpin S. Storniolo, Renata Patrícia da Silva (Organizadoras)

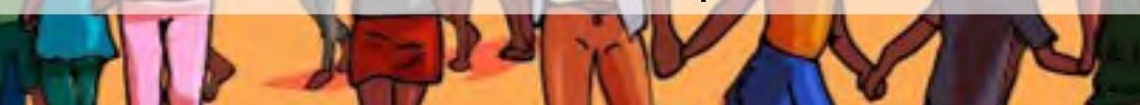


Mesmo com os dispositivos legais, com a luta dos indigenas nos movimentos durante sua história, nos quais participavam inclusive de cargos políticos na gestão escolar e dentro da sala de aula; a escola indígena ainda não é aquela almejada por seus povos. Eles ainda enfrentam muitas dificuldades, de diversas naturezas. Os professores acreditam que há a necessidade de valorizar a cultura; fortalecer a identidade, com várias ações por meio da Arte, da Geografia e da cultura. Eles colocam a escola como um lugar no qual podem desenvolver ações, para valorização, inclusive, da medicina tradicional indigena.

Segundo Bourdieu (1989), a escola é um espaço social que a cultura revela-se e se constitui pelos agentes que nele se relacionam. Esses agentes representam grupos que se caracterizam por princípios particulares de visão e pelo seu modo específico de ver o mundo: Povo Akwẽ e cultura Xerente. Suas histórias caracterizam o modo particular de cada grupo social que estão refletidas na história de cada um e que se manifestam na sua cultura.
Outro problema, não menos grave, enfrentado na rotina escolar é a constante reivindicação de ser ouvido. Isso reverbera o predomínio do preconceito e visão colonial. Eles precisam conquistar esse espaço. Há um colonialismo mental e relativismo cultural, o que tem impedido que os saberes da escola estejam relacionados com o saber formal.

\section{Bdâdi Adu It Kmãwazrê Da15: Portas a Abrir}

Observa-se que na Escola Estadual Indigena Wakõmẽkwa os sistemas e dispositivos que se movimentam no interior das suas estruturas sociais são reflexos de práticas, tanto individuais quanto coletivas, que estabelecem rotinas corporais e mentais (THIRY-CHERQUES, 2006). Os sistemas, que podem ser estáveis

15 Tradução do Akwẽ para o português: Caminhos percorridos.

\section{Trânsitos Interdisciplinares em Artes \\ Bárbara Tavares dos Santos, Liliane Scarpin S. Storniolo, Renata Patrícia da Silva (Organizadoras) HIb ding}


ou removiveis, se tornam principios geradores e organizadores das práticas e representações de uma classe de suas condições de existência.

Nesse sentido, um reinventar da escola indigena é uma condição sine qua non, por meio da interlocução entre a igualdade e a diferença. É preciso encontrar meios, considerando as demandas locais e específicas da comunidade escolar Wakõmẽkwa para desenvolver um ensino a partir de principios de um pensamento pós-abissal. Dessa forma, primar por um ordenamento social e educacional que supere a lógica da apropriação/violência de práticas de epistemicidio, interrompendo a matriz colonial por uma lógica da regulação/emancipação (WALSH, 2009: SANTOS, 2010a; 2010b).

A vista disso, por meio da memória coletiva, o Ensino das Artes pode ser uma das vias para um compartilhamento de experiências e ações educativas, a partir das lembranças revisitadas e reconstruidas pela nova geração, com o apoio dos mais velhos, como, por exemplo, os anciãos e anciãs, caciques, pajés, professores e professoras. E assim, os povos indigenas Akwẽ poderão dar continuidade a sua história, sem o sentimento de que ela está sendo "esquecida" ou deixada a escanteio. Por meio do Ensino das Artes, a cultura Akwẽ poderá se fazer presente, porque ela está viva e sempre esteve entre os Povos Xerente. Consequentemente, não ocultar as desigualdades, contradições e conflitos, mas trabalhar com e intervir nelas (SACAVINO, 2012).

Rever a legislação e o currículo nesse cenário também é uma condição indispensável, de modo que: estabeleça critérios para a construção de um currículo, na perspectiva rizomática, que subjugue também o rigor do curriculo escolar oficial, imposto nas escolas indigenas (DINIZ; COSTA; DINIZ, 2011). Novas discussões para um curriculo flexivel, específico e diferenciado oferecem possibilidades para um processo educativo que valorize a territorialidade, a experiência local e a identidade do povo. Logo, valorizar o outro saber que não está no território de origem. Por isso, nesse processo de reivindicação, elaboração e discussões de propostas que possam ser efetivadas na escola indígena, de modo

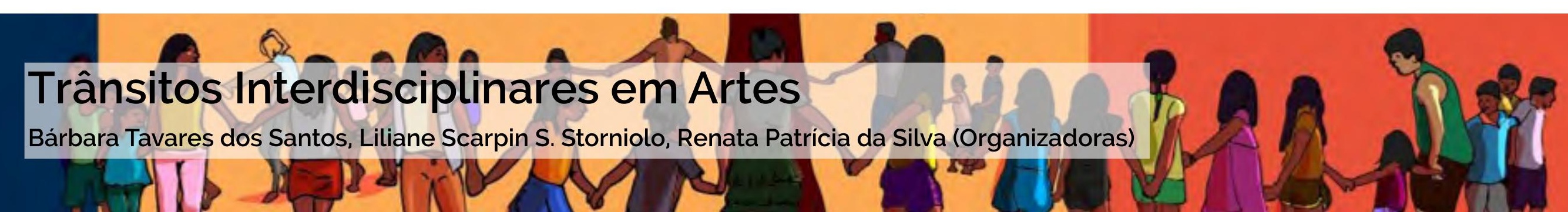


especial a Wakõmẽkwa, campo desse estudo, deve se envolver: a comunidade escolar com seus representantes da liderança. Bem como, pensar e desenvolver cursos de capacitação aos professores para uma possivel mudança nas práticas educacionais, de modo que elas sejam desenvolvidas considerando o saber-fazer e o fazerfazer, a partir do sentir, experienciar e ser, é igualmente importante (LIBÂAEO, 2011). E não apenas o saber por saber, que pode não culminar numa aprendizagem efetiva. $\bigcirc$ fazer sem querer também pode resultar numa obrigação, por isso a necessidade de despertar o desejo pelo que está sendo ensinado e aprendido. O saber que destacamos aqui deve vir associado ao querer e ao fazer. Assim, o professor deve pensar em desenvolver ação pedagógica crítica, que supere o simples fazer de repetição ou reprodução. É necessário reflexão sobre a prática, a partir das condições sociais concretas. Para isso, o aluno precisa entender o sentido do que está sendo ensinado, de modo que possa refletir sobre a prática (LIBÂNEO, 2011).

O professor tem influência no processo de ensinar e aprender no ambiente escolar. É necessário que ele esteja preparado quanto ao que vai ensinar, a partir de métodos e técnicas de ensino e aprendizagem. Ele tem que ter clareza sobre o que pretende ensinar, com objetivos educativos definidos, em sinal, inclusive, de respeito às suas origens. Um dos professores da escola pesquisada relata que ".... a dificuldade está relacionada ao ensino devido à falta de livro didático na linguagem Akwẽ. Os professores têm conteúdo, mais não sabem como ensinar".

No espaço escolar, o ensino e a aprendizagem tem que ter uma intenção, devendo ser planejado e orientado para alguns objetivos, para provocar uma transformação da capacidade intelectual do aluno, para que, progressivamente, domine os conhecimentos e habilidades desenvolvidos na escola e saiba aplicá-los em sua vida prática. Isso ocorre devido à capacidade que o sujeito tem para aprender (LIBÂNEO, 1994).

Consequentemente, para ensinar não basta ter somente o conteúdo para apresentar. Para muitos a sala de aula é o lugar ideal para o ensino, mas não se pode limitá-lo a esse espaço. Os professores indigenas veem o processo ensino e aprendizagem
Trânsitos Interdisciplinares em Artes

Bárbara Tavares dos Santos, Liliane Scarpin S. Storniolo, Renata Patrícia da Silva (Organizadoras) 
como algo que acontece na comunidade, porque tem relação com a cultura, com seus costumes, com os saberes tradicionais.

Nisso, com as relações associadas ao saber escolar. o aluno se torna sujeito, um agente ativo e passa a ser capaz de dar sentido a tudo que vivencia na escola, uma vez que a relação com o saber é a relação consigo mesmo, com o outro e com o mundo. Consequentemente, essas relações podem contribuir na constituição da identidade do sujeito aluno e ele terá melhores condições de compreender a si mesmo diante do outro e de manter relações de troca com agentes de sua cultura e de outras culturas, pela interpretação do mundo que o cerca, sem perder sua essência.

Nesse contexto, percebemos, a partir dos indicativos desse estudo, que o Ensino das Artes, como expressão da cultura Akwẽ. pode ser a possibilidade de uma (re)invenção da escola indigena para uma prática intercultural pós-colonial na Escola Estadual Indigena Wakõmẽkwa.

\section{Referências - Rêsuka}

ARAÚJO, R. N. de. Os territórios, os modos de vida e as cosmologias dos indigenas Akwẽ-Xerente, e os impactos da UHE de Lajeado. Tese de Doutorado - Programa de Pós-Graduação em Geografia - Centro De Ciências, da Universidade Federal do Ceará: Fortaleza, 2016.

BARBOSA, A. M. (Org.). Arte-educação: leitura no subsolo. 9. ed. São Paulo: Cortez, 2013

BOURDIEU, P. O poder simbólico. Tradução de Fernanda Tomaz. Rio de Janeiro: Editora Bertrand Brasil, 1989.

BRASIL. LDB: Lei de Diretrizes e Bases da Educação Nacional: Lei no 9.394, de 20 de dezembro de 1996, que estabelece as diretrizes e bases da educação nacional. 8. ed. Brasília: Câmara dos Deputados, Edições Câmara, 2013

DINIZ, F. P. S.: COSTA, A. C. L. da; DINIZ, R. E. S. Territórios, Rizomas e o Currículo na Escola. Revista Educação, v. 12, n. 2, p. 313-328, jul./dez. 2011;

DURKHEIM, É. Educação e Sociologia: com um estudo da obra de Durkheim, pelo prof. Paul Fauconnet. 6. ed. Tradução de Lourenço Filho. São Paulo: Melhoramentos, 1965.

DURKHEIM, É. Da divisão do trabalho social. Tradução de Eduardo Brandão. 2. ed. São Paulo: Martins Fontes, 1999.

\section{Trânsitos Interdisciplinares em Artes \\ Bárbara Tavares dos Santos, Liliane Scarpin S. Storniolo, Renata Patrícia da Silva (Organizadoras)

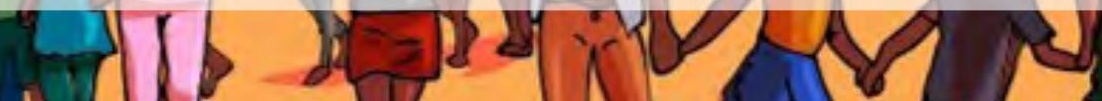


FLEURI, R. M. Intercultura e educação. Revista Brasileira de Educação, Rio de Janeiro, v. 10, n. 23, p. 16-35, maio/ago. 2003.

LAGROU, E. Arte indígena no Brasil: agência, alteridade e relação. Belo Horizonte: C/ Arte, 2013.

LIBÂNEO, J. C. Didática. São Paulo: Cortez, 1994

LIBÂNEO, J. C. Saber, saber ser, saber fazer: o conteúdo do fazer pedagógico. In: Democratização da escola pública: a pedagogia crítico-social dos conteúdos 26. ed. São Paulo: Edições Loyola, 2011, p. 47-59

LIMA, L. G. B. Os Akwê-Xerente no Tocantins: território indígena e as questões socioambientais. Tese (Doutorado) - Faculdade de Filosofia, Letras e Ciências Humanas da Universidade de São Paulo. Departamento de Geografia. São Paulo, 2016, $320 \mathrm{f}$

HENRIQUES, R. et al. Educação Escolar Indígena: diversidade sociocultural indigena ressignificando a escola. Ministério da Educação. Secretaria de Educação Continuada, Alfabetização e Diversidade. Brasília: Sedac/MEC, 2007.

MEC. Referencial curricular nacional para as escolas indígenas. Ministério da Educação e do Desporto. Secretaria de Educação Fundamental. Brasilia: MEC/ SEF/DPEF, 1998

MEC. Resolução n 2, de 28 de abril de 2008. Ministério da Educação. Brasilia, 2008
MEC. Base Nacional Comum Curricular. 3. ed. Ministério da Educação. Brasilia, 2017

MOREIRA, A. F.: CANDAU, V. M. Currículos, disciplinas escolares e culturas. Petrópolis, RJ: Vozes, 2014

MUNIZ, S. de S. Educação Escolar Indigena no Estado do Tocantins: uma trajetória histórica do curso de capacitação ao curso de formação do Magistério Indígena. Dissertação - Programa De Pós-Graduação Em Letras - PPGL: Ensino De Língua e Literatura da Universidade Federal Do Tocantins, UFT, 2017, 144 P. PENTEADO, A: CARDOSO JUNIOR, W. C. Arte, cultura e sujeitos nas escolas: os lugares de poder. In: MOREIRA, A. F.: CANDAU, V. M. (Orgs.). Currículos, disciplinares escolares e culturas. Petrópolis: Vozes, 2014, p. 215-254.

SACAVINO, S. Interculturalidade e Educação: desafios para a reinvenção da escola. XVI ENDIPE - Encontro Nacional de Didática e Práticas de Ensino UNICAMP - Campinas, 2012. Disponivel em: http://www.infoteca.inf.br/endipe/ smarty/templates/arquivos_template/upload_arquivos/acervo/docs/3892b. pdf. Acesso em: 14 abr. 2018

SANTOMÉ. J. T. As Culturas Negadas e Silenciadas no Curriculo. In: SILVA, T. T. da. Alienígenas na sala de aula. Petrópolis: Vozes, 1995.

SANTOS, J. L. dos. O que é Cultura. 15. ed. São Paulo: Brasiliense, 1994.

SANTOS, B. de S. Para além do pensamento abissal: das linhas globais a uma ecologia de saberes. In: SANTOS, Boaventura de Sousa; MENESES, Maria Paula (Orgs.). Epistemologias do Sul. São Paulo: Cortez, 2010a, p. 31-83.

\section{Trânsitos Interdisciplinares em Artes}

Bárbara Tavares dos Santos, Liliane Scarpin S. Storniolo, Renata Patrícia da Silva (Organizadoras)

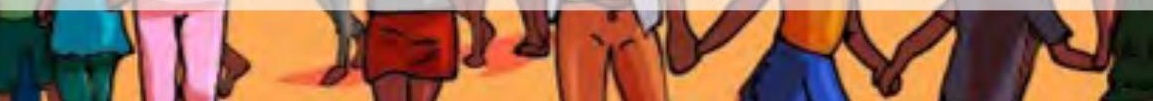


SANTOS, B. de S. A gramática do tempo: para uma nova cultura política. 3. ed. São Paulo: Cortez, 2010b.

SILVA, T. T. da. Documentos de Identidade: uma introdução às teorias do curriculo. 3. ed. Belo Horizonte: Autêntica Editora, 2015

SOUZA, Raquel Castilho. Aeducação escolar indigena interculturale o ensino das artes: um olhar sobre as práticas da escola Wakõmẽkwa na comunidade Riozinho Kakumhu - povo Xerente - Tocantins. São Paulo, 2019, 258 f.

THIRY-CHERQUES, H. R. Pierre Bourdieu: a teoria na prática. RAP. Rio de Janeiro, v. 40, n. 1, p. 27-55, jan./fev. 2006. Disponivel em: http://Www.scielo.br/ pdf/rap/v4On1/v4On1a03.pdf. Acesso em: 2 abr. 2018

TOCANTINS. Lei $\mathbf{n}^{\circ}$ 1038, DE 22 DE DEZEMBRO DE 1998. Publicado no Diário Oficial $n^{\circ}$ 753. Governador do Estado do Tocantins - Assembleia Legislativa do Estado do Tocantins. Disponivel em: <file:///D:/Users/Usuario/ Downloads/22258\%20(1).pdf>. Acesso em: 10 abr. 2018.
TOCANTINS. LEI No 78, de $\mathbf{2 0}$ de junho de 2007. Governador do Estado do Tocantins - Secretaria da Educação e Cultura, Conselho Estadual de Educação.

VENÂNCIO, M.: CHELOTTI, M. C. Efeitos Socioespaciais de Grandes Empreendimentos: o caso da barragem de Lajeado sobre o povo Xerente no Estado do Tocantins. Espaço em Revista, v. 18, n. 1, jan/jun. 2016. p. 114-131. Disponivel em: file:///D:/Users/Usuario/Downloads/42247-Texto\%20do\%20 artigo-188522-2-10-20170106.pdf. Acesso em: 29 jan. 2019.

WALSH, C. Interculturalidad crítica y pedagogia de-colonial: apuestas (des) de el in-surgir, re-existir y re-vivir. 2009. Disponivel em: http://www.maxwell. vrac.puc-rio.br/13582/13582. Acesso em: 05 nov. 2018

WEWERING, S. T. (Org.). Povo Akwẽ Xerente: vida, cultura e identidade. Belo Horizonte: Editora Rona, 2012.

\section{Trânsitos Interdisciplinares em Artes}

Bárbara Tavares dos Santos, Liliane Scarpin S. Storniolo, Renata Patrícia da Silva (Organizadoras)

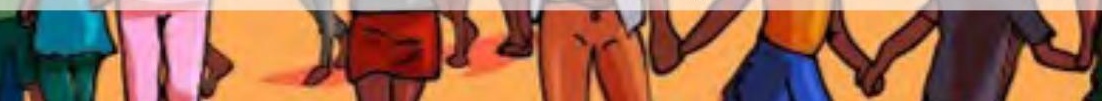


$\rightarrow$

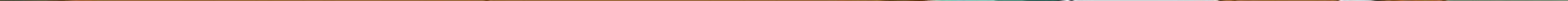




\section{Fragmentos Históricos da Formação Brasileira: Uma História de Etnocídio e Extermínio dos Povos Indígenas}

Silvia Regina da Silva Costa ${ }^{1}$ Carminda Mendes Andréz

Professora Adjunta I na Universidade Federal do Tocantins (UFT), Câmpus de Araguaina, Licenciatura em Matemática, e-mail: silviacosta@uft.edu.br

2 Professora da pós-graduação em Artes do Instituto de Artes (IA) da Unesp. Câmpus São Paulo, e-mail: carmindadinter@gmail.com.

\section{Trânsitos Interdisciplinares em Artes}

Bárbara Tavares dos Santos, Liliane Scarpin S. Storniolo, Renata Patricia da Silva (Organizadoras 
Milhares de anos anteriormente à invasão, já habitavam no território brasileiro os mais variados povos indigenas, de acordo com pesquisas de arqueólogos e etnólogos que descobriram materiais arqueológicos, um crânio em específico, cerâmicas e que são objetos de pesquisa até a atualidade, com o auxilio dos próprios indígenas para realização dos estudos da pré-história indigena brasileira (MELATTI, 2014).

Cunha (1992) corrobora que "quanto à antiguidade do povoamento, as estimativas tradicionais falam de 12 mil anos, mas muitos arqueólogos afirmam a existência de sítios arqueológicos no "Novo Mundo" anteriores a essas datas [...]" (p. 10). Diante disso os povos originários já habitavam o continente há milhares de anos quando acontece "a introdução no seu mundo de um protagonista novo, o europeu. Embora minúsculo, o grupelho recém-chegado de além-mar era superagressivo e capaz de atuar destrutivamente de múltiplas formas. Principalmente como uma infecção mortal sobre a população preexistente, debilitando-a até a morte" (RIBEIRO, 2015. p. 25).
Mas a história da história dos índios no Brasil inicia-se, na maioria dos livros com o suposto descobrimento "[...] no dia 22 de abril de 1500, pela frota comandada pelo navegador português Pedro Álvares Cabral. Na nau capitânia viajava um passageiro para Calicute, Pero Vaz de Caminha, destinado ao lugar de escrivão geral desta feitoria na Índia, aproveitou a ocasião para escrita da 'carta de achamento'" (BETTENCOURT, 2000, p. 39).

A carta traz nuances particulares do olhar de Pero Vaz de Caminha sobre a terra encontrada e muito se observou aos povos indigenas que aqui se encontravam na ocasião da invasão europeia. Num dos trechos iniciais de sua carta ele narra: "Eram pardos, todos nus, sem coisa alguma que thes cobrisse suas vergonhas. Nas mãos traziam arcos com suas setas. Vinham todos rijos sobre o batel; e Nicolau Coelho lhes fez sinal que pousassem os arcos. E eles os pousaram", mostrando dessa feita a pacificidade dos indígenas com os supostos novos visitantes, não havendo intenção alguma de guerra ou disputa pela terra, visto que na primeira oportunidade abaixaram seus arcos e foram conhecer aqueles

\section{Trânsitos Interdisciplinares em Artes}


invasores implacáveis, que seriam seus algozes logo em breve (BETTENCOURT, 2000, p. 39)

Uma curiosidade sobre a terminologia "índios" é que ao aportarem na América, os europeus nominaram os habitantes locais de indios por acreditarem estar em terras das Índias. "Mesmo depois de suas explorações terem nos levado a perceber seu engano, demonstrando que a América constituía um continente à parte, distinto da Ásia, os habitantes do Novo Mundo continuaram a ser chamados de índios" (MELATTI, 2014, p. 31).

Essa generalização pode ser analisada como uma suposta forma de subjugar os indígenas e transformá-los em uma única população, em seres iguais, sem identidade, ignorando que as populações eram diferentes, tanto em aspectos físicos como em suas tradições. Nada havia de comum entre as populações aqui encontradas que pudessem justificar a denominação única de índios, a não ser pelo "fato de não serem europeus" (MELATTI, 2014, p. 32).

Complementando o sentido de subjugação e tentativa de inferiorizar os povos indígenas, temos "categorias" que foram utilizadas pejorativamente para eles: "os mansos e os bravos, os Tupi e os 'Tapúya', os selvagens e civilizados". Diante desse quadro, não faremos uso do conceito de tribo "por sua imprecisão, por sua plasticidade altamente manipulável, por ser um termo utilizado pelos conquistadores para se referir aos conquistados" (RAMOS, 1988, p. 10).

A vulnerabilidade dos povos indígenas que aqui viviam ao choque epidemiológico que é resultado da "união microbiana do mundo completada pelos Descobrimentos", aparece como um fator que contribuiu com a restrição dos cativeiros indígenas, mas que infelizmente na medida em que restringiu a escravidão, houve a incrementação da escravidão negra. "Em virtude do fracionamento demográfico, da dispersão territorial e da ausência de animais domesticados (suscetiveis de zoonoses), os povos pré-cabralinos permaneciam ao abrigo das pandemias que açoitavam o Velho Mundo" (ALENCASTRO, 2000, p. 127).

O etnocídio, genocídio ou morticínio dos povos indígenas inicia-se com uma guerra biológica, na qual os europeus do

\section{Trânsitos Interdisciplinares em Artes}


chamado "Antigo Mundo" trazem consigo as mais variadas doenças ao chamado "Novo Mundo". De um lado, povos peneirados, nos séculos e milênios por pestes e para as quais desenvolveram resistência. Do outro lado, povos indenes, indefesos, que começavam a morrer aos magotes e é assim que Ribeiro (2015. p. 37) relata a chegada dessa branquitude letal aos indigenas que "trazia da cárie dental à bexiga, à coqueluche, à tuberculose e ao sarampo."

Muito mais avassalador, segundo historiadores e etnohistoriadores, foram as epidemias de doenças que acompanharam os europeus e africanos. "Varíola, sarampo, catapora - as famigeradas bexigas -, febre amarela, tuberculose e as gripes e pneumonias arrasaram aldeias inteiras, aniquilaram povos inteiros. Muitas vezes foram aldeias que nem contato com as fontes irradiadoras tinham, mas que recebiam a doença por transmissão de outros índios em contatos até fortuitos" (GOMES, 2012, p. 59).

A guerra biológica letal foi apenas o início do etnocídio ocorrido no continente americano, visto que, ainda aconteceram guerras de extermínio, escravização e ainda a catequização forçada, um "alto plano jesuítico que regeu e ordenou a colonização. Um somatório de violência mortal, de intolerância, prepotência e ganância. Todas as qualidades mais vis se conjugaram para compor o programa civilizador de Nóbrega" (RIBEIRO, 2015, p. 40-41).

Concomitantemente ao massacre dos povos indigenas pelas vias biológicas, aconteciam, também, as guerras de extermínios, que por algum tempo tiveram aval do governo e posteriormente mesmo com a proibição de tal prática, os indigenas continuaram a ser mortos por particulares, fossem eles mineradores, fazendeiros ou quem quer que desejasse as terras nas quais estavam ocupando naquele momento.

Ao falar sobre a experiência de vida e as mortes dos indigenas, Ribeiro (2017, p. 107) pontua que os que se opusessem "ao avanço das fronteiras da civilização eram caçados como feras desde os igarapés ignorados da Amazônia até as portas das regiões mais adiantadas." Os índios que eram denominados "civilizados" e que foram obrigados a conviver com as pessoas que

\section{Trânsitos Interdisciplinares em Artes}


invadiram seus antigos territórios, "[...] incapazes de se defenderem da opressão a que eram submetidos, viviam seus últimos dias."

Foram enxotados de suas próprias terras e, ainda, "eram escravizados em seringais e nas fazendas onde enfrentavam condições de vida a que nenhum povo poderia sobreviver". Gomes (2012), afirma que algumas das guerras de exterminios, como na Bahia, no ano de 1558, sob o governo Mem de Sá foram exterminados de 14 a 30 mil indigenas tupinambás, com o intuito de conter sua rebeldia e resistência. E nessa toada de consolidar o Brasil pelos portugueses, a vida dos indígenas apresentava-se incompativel com os intentos dos invasores portugueses.

Chaui (2000) colabora com reflexões importantes que compõem a história dos povos indígenas no Brasil, essa identidade forçada e forjada pelos ktâwanõ:

Contraposta à imagem boa e bela dos nativos, a ação da conquista ergueu uma outra, avesso e negação da primeira. Agora os 'índios' são traiçoeiros, bárbaros, indolentes, pagãos, imprestáveis e perigosos. Postos sob o signo da barbárie, deveriam ser escravizados, evangelizados e, quando necessário, exterminados (CHAUI, 2000, p. 12).

Ribeiro (2015), pontua acerca do alto plano jesuítico que comandou a colonização, um "somatório de violência mortal, de intolerância, prepotência e ganância. Todas as qualidades mais vis se conjugaram para compor o programa civilizador de Nóbrega. Aplicado a ferro e fogo por Mem de Sá", tal programa proporcionou o extermínio, em torno de 300 (trezentos) aldeamentos indigenas no litoral brasileiro no século XVI (RIBEIRO, 2015, p. 41).

Todas as atitudes elencadas minimamente nesse item introdutório sobre a história brasileira é fundada com base em leis, decretos, cartas régias, entre outros, tendo como principio legal as bulas papais, ou seja, tais atrocidades foram praticadas com respaldo legal do Vaticano e da Coroa Portuguesa. E é sob a ótica de tais documentos que abordaremos a política indigenista nos tópicos seguintes. Iniciaremos dessa forma com o período colonial, por ser "oficialmente" o primeiro momento no qual os indigenas aparecem na história.

\section{Trânsitos Interdisciplinares em Artes}


Politicas Indigenistas: Caminhos Atravessados pelo Ktâwanõ

É quase um disparate tentar falar em políticas indigenistas, em leis que pudessem proteger a integridade física e defender as terras indigenas num cenário histórico construido a partir dos massacres ou até mesmo da morte de povos indígenas em sua totalidade. Falar em leis que trabalham na contramão de direitos é revoltante e aviltante. mas não podemos escapar a essa fatídica história que foi construida, moldada e edificada pelas mortes de milhões de indigenas.

História que construiu um ideário, um mito, um senso comum da figura indigena atravessando os séculos, que ora varia de guerreiros altivos a antropófagos, perigosos, letais; órfãos que precisam de atenção especial (que nunca foi dada) ou de um viés romanceado enviesado construido à custa de um indigena que aceita tudo pacificamente, que é subserviente aos "brancos"; mas ainda temos o indígena sujeito de direitos, que a constituição cidadã de 1988 tenta inaugurar.
Nosso intento é de que consigamos explicitar as políticas indigenistas por períodos, com o intuito de facilitar a compreensão, dentro da história nacional, a partir do periodo colonial, adentrando ao imperial, republicano que inclui o período da ditadura e finalmente a democracia com a instituição da CF de 1988. Essas composições históricas objetivam abordar como a legislação atuou junto à questão indígena, bem como qual atenção lhes foi dada durante a composição da história brasileira.

\section{Período Colonial: dos Guerreiros do "Descobrimento" a Antropófagos}

Iniciamos nossas reflexões acerca do presente subitem com a transcrição do texto de Perrone-Moisés (1992, p. 116) ao abordar os princípios da legislação indigenista no período colonial: "Contraditória, oscilante, hipócrita: são os adjetivos de forma unânime, para qualificar a legislação e a política da Coroa portuguesa em relação aos povos indígenas do Brasil Colonial."

\section{Trânsitos Interdisciplinares em Artes}


Todos os subterfúgios possiveis foram utilizados para "justificar" o injustificável, que era a morte dos indígenas para tomada de suas terras e riquezas de uma forma em geral, desde a "guerra justa" aos "descimentos" e "aldeamentos", todos numa tentativa inapropriada e deslocada da realidade na qual a morte acabava sendo a única "solução" imputada aos indigenas ao longo da história colonial.

Mesmo antes da invasão ao continente americano, 0 Vaticano se antevê, por meio da Inter Coetera, de 4 de maio de 1493. autorizando que a invasão do chamado Novo Mundo era legitima pela Espanha e Portugal, sendo que seus povos poderiam ser escravizados por quem os subjugasse (SOARES, 1939 apud RIBEIRO, 2015):

"Portugal já se achava acautelado por sanção papal desde 1454, quando Nicolau V. pela Bula Romanus Pontifex, garantira-lhe o direito de conquistar terras novas, de 'bárbaros' ou de 'infiéis', e submeter seus povos à servidão pelo uso da guerra." Acerca do projeto colonial os povos indígenas eram fixados como "súditos do rei, vassalos em sua própria terra e seres socialmente inferiores aos portugueses" (GOMES, 2012, p. 75-76).

Ao discutir a política indigenista no período colonial, Gomes (2012) dispõe sobre as principais legislações até a independência do Brasil, elencadas em 22 tópicos. Uma análise mais aprofundada sobre as minúcias de cada legislação não está entre nossos objetivos, por se tratar de uma temática extremamente necessária para se entender o contexto no qual os povos indígenas foram subjugados, mortos, colocados uns contra os outros, desqualificados como seres humanos. Para Perrone-Moisés (1992),

Tomada em conjunto, a legislação indigenista é tradicionalmente considerada como contraditória e oscilante por declarar a liberdade com restrições do cativeiro e alguns casos determinados, abolir totalmente tais casos legais de cativeiro (nas três grandes leis de liberdade absoluta: 1609, 1680 e 1755), e em seguida restaurá-LOS (PERRONE-MOISÉS, 1992, p. 117).

\section{Trânsitos Interdisciplinares em Artes}


O Brasil Colonial contava com o título de índios amigos/ aliados e indios inimigos, lembrando que para cair nesse fosso da semântica nominal de inimigo, bastava pura e simplesmente não seguir as ordens da coroa portuguesa. Indigenas que não se rendiam ao subjugo imposto pela colônia ou à religião, o catolicismo, eram tidos como inimigos (PERRONE-MOISÉS, 1992).

Os "índios amigos", "índios das aldeias" ou "índios de pazes" tinham um itinerário a seguir que fora definido pela coroa, que deveria acontecer em primeiro lugar o "descimento", serem catequizados e "civilizados", "de modo a tornarem-se 'vassalos úteis', como dirão documentos do século XVIII." Desses indígenas eram compostos as "tropas de guerra contra inimigos tanto indigenas quanto europeus" (PERRONE-MOISÉS, 1992).

Inacianos se aliavam com autoridades e colonos para implementar o sistema de descimento que tinha três objetivos: o primeiro seria em criar aldeamentos dos índios "mansos" com a finalidade de proteger os colonos dos índios "bravos", o segundo "os aldeamentos circunscreviam as áreas coloniais, impedindo a fuga para a floresta tropical dos escravos negros das fazendas e dos engenhos" e, por último, "manter contingentes de mão de obra compulsória nas proximidades das vilas e dos portos" (ALENCASTRO, 2000, p. 181).

No periodo colonial, a política indigenista contava com nomenclaturas específicas àquela época a despeito dos povos indígenas e seu tratamento, tais como: "índios aldeados e aliados, indios inimigos, descimento 3 , aldeamento, administração das aldeias, trabalho indigena, escravidão indigena, guerra justa4, guerra total ao gentio bárbaro, escravização decorrente da guerra,

3 Trasladação de grupos de indios de seus territórios para locais determinados, especialmente próximos à costa (GOMES, 2012, p. 77).

4 Declaração de guerra a partir de decisão tomada em junta que determinava pela justeza da guerra que se pretendesse efetuar contra determinado povo indigena. Os principais critérios para tanto eram: (a) que os indios punham empecilho à propagação da fé católica: (b) atacavam povoados ou fazendas portuguesas; (c) que eram antropófagos; (d) que eram aliados de inimigos portugueses (Ibid., p. 78).

\section{Trânsitos Interdisciplinares em Artes}


resgate, ${ }^{5}$ bandeira, ${ }^{6}$ entrada, ${ }^{7}$ aldeias de repartição, ${ }^{8}$ aldeias de administração, ${ }^{9}$ junta ou junta de missão, ${ }^{10 "}$ entre outros (PERRONEMOISÉS, 1992, p. 117-127: GOMES, 2012, p. 77-78).

O principal caso reconhecido de escravização legal é o que procede da guerra justa. Dentre as causas consideradas legítimas

5 Ato de obter prisioneiro índio de outro grupo indigena por troca, supostamente para salvá-lo de morte certa. Posteriormente, o pretexto invocado foi a salvação dos índios das penas do inferno (Ibid., p. 78).

6 Empresa particular que efetuava expedições para dar caça e aprisionar os índios (ou procurar ouro ou pedras preciosas). Muitas foram contratadas por oficiais da Coroa; outras eram ilegais - sobretudo associadas aos paulistas (Ibid., p. 78).

7 Expedição para efetuar descimentos. Em geral, era dirigida por uma autoridade oficial (mas podia ser por um particular), ordenada por uma junta de missão, com ou sem a presença de missionários (GOMES, 2012, p. 77)

8 Aldeias para onde eram trazidos indios descidos para depois serem distribuidos entre autoridades e particulares (lbid., p. 78).

9 Aldeias de indios descidos sob a jurisdição das Câmaras ou dos governadores ou capitãesgenerais (GOMES, 2012, p. 78)

10 Conselho local formado pelos representantes das missões, o bispo e oficiais do rei, que decide sobre a legitimidade das questões indígenas, sobretudo as guerras e a distribuição de indios descidos (Ibid., p. 78). de guerra justa estão a negativa de convertimento ao catolicismo ou "impedimento da propagação da Fé, a prática de hostilidades contra vassalos e aliados dos portugueses (especialmente a violência contra pregadores, ligados à primeira causa) e a quebra de pactos celebrados." (PERRONE-MOISÉS, 1992, p. 123).

Uma caracteristica peculiar do periodo colonial é a união da Igreja e da Coroa chamada de Padroado, utilizada com o intuito de fazer a gestão da colonização massivamente massacradora de povos indígenas. Por muito tempo, Mem de Sá e o Padre Manuel de Nóbrega conjugavam de ideais e ideias similares acerca de fazerem uma incorporação do indígena à sociedade envolvente. Foi "apenas em 1755, com o Marques de Pombal é que houve uma cisão entre Coroa e a Igreja, ou ao menos o segmento missionário, no que se refere ao trato administrativo dos índios" (GOMES, 2012, p. 82).

A referida cisão acima da Igreja e Coroa culmina na aprovação de um regimento datado do ano de 1758 em favor dos indios, reconhecendo-os como livres, sem ressalvas; ordenava que se lhes restituísse o uso e gozo de seus bens; dava preferência para

\section{Trânsitos Interdisciplinares em Artes}

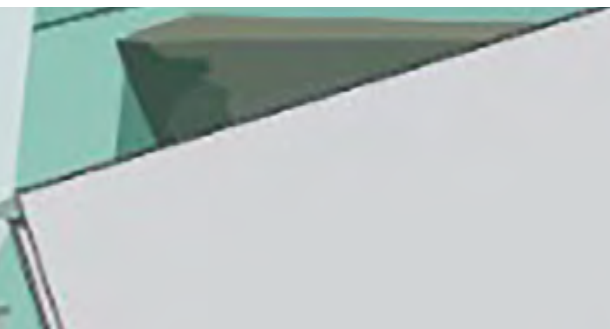


ocupar cargos públicos aos mestiços de branco e índio; proibia apelidá-los de caboclo ou negro.

É importante ressaltar que toda área/região nas quais se levantaram cidades, povoados, que houve a instalação desde as grandes potências agrícolas e pecuárias aos pequenos produtores rurais e posseiros, foram retiradas dos indígenas. "No período colonial, o esbulho de suas terras e o apresamento de suas pessoas não raro se fez em ações bélicas permitidas pelo governo metropolitano e até com a utilização de suas tropas" (MELATTI, 2014, p. 241).

O próximo item a ser explorado será o período imperial no Brasil, no qual após a proclamação da independência, as lutas contra os indigenas não seriam mais permitidas legalmente. "mas ela continuou sendo feita por iniciativa de particulares, que desafiavam as proibições governamentais" (MELATTI, 2014, p. 241).

Fato que permeia as áreas indigenas até nossa atualidade. incluindo nessa discussão em pleno século XXI, no ano de 2018 . um candidato à Presidência da República Federativa do Brasil que coloca como objetivos de sua plataforma política a "retomada" das terras indigenas que são cheias de riquezas aos brasileiros que seriam seus verdadeiros "donos".

\section{Período Imperial: da Orfandade ao Romantismo Alencariano}

O Período Imperial no Brasil é compreendido entre a Proclamação da Independência em 1822 e a Proclamação da República em 1889, lembrando que foi dividido em dois períodos imperais, de Dom Pedro I e Dom Pedro II e a intervenção do governo regencial no intervalo em que Dom Pedro II atingiria a maioridade legal. Tal periodo segue logo após o fim do período colonial que totalizou 322 anos

Com a independência do Brasil em 1822, inicia-se o período imperial, mas a herança dos aldeamentos, ainda, é "presente" dos colonizadores que entendem como melhor alternativa a

\section{Trânsitos Interdisciplinares em Artes}


continuidade dos trabalhos catequéticos, mas com a introdução dos freis capuchinhos, em 1843. Em 1845, novo decreto dispõe sobre a "instrução civica e religiosa dos índios, sua iniciação nas artes e ofícios dos civilizados, a fiscalização sobre a maneira como eram empregados como trabalhadores, o esforço para fixar as sociedades nômades, à ajuda às viúvas e às crianças" (MELATTI, 2014, p. 251).

Legislações criadas no periodo colonial tinham fortes tendências a tornar os indígenas vassalos e aos que não aderissem a tal prática, seriam escravizados à força ou mortos. O império é caracterizado por um

[...] período de paz e lento progresso. Na verdade, foi o período que estabeleceu o poder dos grandes senhores pela manutenção da escravatura e do latifúndio, e onde se cercaram as portas para um possivel surgimento da pequena propriedade e, portanto, de uma atitude democrática entre seu povo. $[\ldots]$

A política indigenista era aplicada por um órgão, a Diretoria Geral dos Índios, que deveria haver em cada província. $O$ diretor-geral era nomeado pelo imperador, e ele indicava para nomeação pelo presidente da província os 'diretores parciais' para cada 'diretoria' criada onde houvessem índios. A diretoria tinha as funções de relacionamento direto com os índios, mais ou menos aquilo que veio a se chamar mais tarde de 'posto indigena' (GOMES, 2008, p. 88 e 431).

Sobre as terras houve uma regularização da propriedade territorial no país, dividindo-as em duas categorias: uma que era constituida pelas terras públicas pertencentes ao Estado; e a segunda por terras particulares, "provenientes de um título legítimo de propriedade ou de uma simples posse legalizada" (GOMES. 2012, p. 88).

Diante disso, os indígenas que não tinham conhecimento sobre tal divisão acabavam por perder suas terras já ocupadas.

\section{Trânsitos Interdisciplinares em Artes}


"Grande parte de suas terras foi usurpada, até mesmo as já doadas anteriormente como sesmarias que, não sendo registradas após 1850, perderam a sua validade aos olhos do governo imperial e das províncias" (MELATTI, 2014, p. 251).

Em 1831 fora promulgada a Lei 27 que tinha como premissa a abolição da servidão indígena, porém eram "cautelarmente" tidos como órfãos, ou seja, sem pai e mãe que pudessem responder legalmente por eles. Diante disso um juiz era imbuido da tarefa de representar seus interesses. "O estabelecimento do caráter de orfandade fundamentou o paternalismo oficial, como demonstra o decreto de 1845", também, chamado de Regimento das Missões (GOMES, 2012, p. 89).

Esse caráter de orfandade, também, foi aprovado pelos liberais e os "amigos dos índios" e entendiam que essa seria a melhor maneira de tratar os indígenas "como crianças, guiando-os na sua vontade, admoestando-os e punindo-os nos seus erros, e procurando o melhor para eles pelo trabalho, a obediência e a religião." Entretanto. isso não impediu que o Estado continuasse a utilizar-se de milícias particulares para o ataque aos aldeamentos, impondo-lhes "lições punitivas aos indigenas sob o pretexto de defender povoados e fazendas de seus ataques" (GOMES, 2012, p. 88).

Bosi (1992, p. 181), após análise das obras de Alencar. afirma que buscou uma exceção a esse papel impetuosamente atribuido ao indigena "[...] encontrei em uma breve passagem, uma nota etnográfica aposta à lenda de Ubirajara". A obra fora a última em que Alencar trata da temática indígena, sendo uma poetização de um período correspondente ao anterior à colonização. Tal passagem faz luz ao que sugeriria que os portugueses se utilizaram de violência na colonização

Podemos verificar que o periodo imperial traz identidades marcadas fortemente a respeito dos indigenas que seriam a de órfãos (legalmente falando) e romanticamente pelas obras alencarianas (por exemplo: O Guarani e Iracema) seria o sujeito que é guerreiro, mas cede ao português, que é escravo, mas por vontade própria, por amor ao outro. Reforçando estereótipos até hoje presentes em nossa sociedade, de que indigenas seriam

\section{Trânsitos Interdisciplinares em Artes}


incapazes em vários sentidos, entre eles, o intelectual, político, cultural, cognitivamente, ou seja, completamente incapazes.

Continuam até a atualidade a existência de pessoas, em especial a determinados setores rurais brasileiros, que ainda pensam que os indígenas podem ser varridos da área que de alguma forma estão "atravancando o progresso econômico", tal pensamento é construido em decorrência do periodo imperial que legalizava tal prática nas cartas régias emitidas. E é com a usurpação das terras indigenas, da continuidade na matança, da escravidão indígena, da exploração sob todas as formas que pudessem ser imaginadas e impingidas aos povos indigenas que aqui persistiam em sobreviver que finalizamos o presente tópico.

Daremos continuidade à política indigenista introduzindo o periodo republicano brasileiro que é dividido historicamente em quatro partes, sendo a última a chamada Nova República na qual vivemos de 1985 até os dias atuais.

\section{Período Republicano}

Adentramos ao período republicano, no qual, o indígena continua ser a "pedra no sapato", a pedra no meio do caminho de Drummond, aquele que atrapalha o progresso e o desenvolvimento do país, aquele que merece a morte como sentença por seu nascimento, aquele que deveria ter morrido por não se adaptar às guerras biológicas infligidas a eles; aquele que não merece as terras que thes restaram; os que deveriam ser incorporados à população brasileira; o indio "comedor de gente" que deveria morrer antes que matassem os "pobres" portugueses.

Historicamente, a República teve início com a Proclamação, em 1889, sendo que a República brasileira é dividida em República Velha (1889-1930) ou Primeira República, Era Vargas ou Nova

\section{Trânsitos Interdisciplinares em Artes}


República (1930-1945), República Populista (1945-1964). Ditadura Militar (1964-1985) e Nova República (1985 até os dias atuais)11.

No início do periodo republicano existiam, em várias localidades, lutas dos até então chamados "civilizados" contra os indigenas, objetivando unicamente expulsá-los de seus territórios. No estado do Paraná e Santa Catarina havia os xoclengues, na luta contra os "brugueiros profissionais" que tinham sido enviados para desalojálos e inserir os colonos alemães e italianos; "eram os botocudos do Espírito Santo e Minas Gerais, que lutavam contra os colonos invasores de seu território; eram os caingangues, em São Paulo, que tentavam bloquear a penetração da Estrada de Ferro Noroeste em suas terras" (MELATTI, 2014, p. 252; RIBEIRO, 2017, p. 119).

Ribeiro (2017) pontua que durante "os primeiros vinte anos de vida republicana nada se fez para regulamentar as

11 Disponivel em: http://www.brasil.gov.br/noticias/cultura/2009/11/brasil-republica. Acesso em: 25 set. 2018 relações com os índios" embora nesse mesmo periodo a abertura de ferrovias através da mata, a navegação dos rios por barcos a vapor, a travessia dos sertões por linhas telegráficas houvessem aberto muitas frentes de luta contra os índios, liquidando as últimas possibilidades de sobrevivência autônoma de diversos grupos tribais até então independentes" (RIBEIRO, 2017. p. 119). Mas que em meio a essa realidade violenta e aterrorizante destoava um grupo de militares que percorriam "as zonas mais desertas do país, desbravando alguns dos últimos redutos de tribos virgens de influências da civilização e assumira diante delas uma atitude amistosa, procurando chamá-las ao convivio com a sociedade brasileira" (RIBEIRO, 2017, p. 107).

Era a Comissão de Linhas Telegráficas e Estratégicas de Mato Grosso ao Amazonas, depois chamada Comissão Rondon que foi criada com o intuito de expandir as linhas telegráficas no interior do país (Mato Grosso e do Amazonas). "Essa obra, que por suas proporções seria uma grandiosa empresa política.

\section{Trânsitos Interdisciplinares em Artes}


econômica e militar, tornou-se, sob a direção de Cândido Mariano da Silva Rondon, um dos maiores empreendimentos científicos e humanisticos jamais tentados" (RIBEIRO, 2017, p. 107).

Darcy Ribeiro era um declarado entusiasta das ações realizadas pelo General Rondon junto aos indigenas e, em definitivo, temos que admitir que contribuiu para amenizar a situação de violência vivida por muitos grupos indígenas espalhados pelo interior do país, bem como a garantia de seus territórios e de trazer uma nova visão desse indígena para a sociedade brasileira. Assim, ele realizava palestras Brasil afora falando de sua experiência junto aos indígenas. $O$ único inconveniente aventado por Ribeiro e Rondon, por exemplo, era de que os indigenas deveriam ser incorporados à nação.

O período republicano é marcado por um período em que todas as terras existentes acabaram por ser vinculadas ao poder central, sendo assim, em decorrência disso, aparece o disposto no artigo 64 da CF de 1891 (a primeira Constituição da República). que transfere aos estados as terras devolutas situadas em seus territórios. Levando em conta que durante os periodos colonial e imperial muitas terras indígenas foram consideradas devolutas, os estados imediatamente passaram a delas se assenhorear. agravando bastante o processo de grilagem em curso sobre as terras indigenas. "Tais terras deveriam comprovadamente apresentar documentos, bem como medições e visitas in loco, que não aconteceram, apossando-se assim os estados das terras nas quais os indígenas, povos originários do país foram veementemente desconsiderados" (ARAÚJO, 2006, p. 26-27).

O governo Nilo Peçanha, pelo Decreto 8.072, de 20 de julho de 1910, cria o Serviço de Proteção aos Índios e Localização de Trabalhadores Nacionais (SPI) que tinha como objetivo maior dar início a uma nova forma de política indigenista, na qual eles poderiam viver a partir de suas tradições, sem a necessidade de abandoná-las, caso não quisessem; a proteção aos indigenas deveria ser garantida dentro do seu próprio território, visto aquele pensamento colonial dos aldeamentos pelos descimentos; fica proibida a separação dos entes que compunham a família indigena,

\section{Trânsitos Interdisciplinares em Artes}


não se justificando, por exemplo, com o pretexto de educação e catequese dos filhos (RIBEIRO, 2017; MELATTI, 2014; GOMES, 2008).

O SPI quando da sua criação comungava com os pensamentos vigentes naquele período, dos quais positivistas e alguns liberais também coadunavam, de que os indigenas fariam parte da sociedade brasileira quase que naturalmente, extinguindo-se totalmente enquanto povo, num processo acelerado de aculturação ou pelo menos de negação de sua cultura e sua própria indianidade.

Com a revolução de 1930, o SPI sai da incumbência do Ministério da Agricultura e vai para o Ministério da Guerra, passando por um período de desprestígio, tornando-se por um bom tempo como atividade irregular e obscura, figurando como um simples departamento da seção de fronteiras. Getúlio Vargas que assume a presidência do país tem divergências ideopolíticas com Rondon e dessa feita o SPI é prejudicado diretamente por tais diferenças. Após esse período obscuro, em 1939, Vargas reconhece a importância dos trabalhos desenvolvidos por Rondon e cria o Conselho Nacional de Proteção ao Índio sob a gestão de
Rondon que tem como objetivo "orientar e supervisionar as ações indigenistas do SPI" (GOMES, 2012, p. 93).

Consideremos a década de 1940 até o governo de Juscelino Kubitschek, na qual o SPI experiencia a comunhão de ações com o governo federal e até mesmo com a sociedade. O ápice da gestão de Rondon tem marcado na memória dois eventos: o primeiro foi em 1953 a criação do Museu do Índio e que posteriormente dá origem ao primeiro programa de Pós-graduação em antropologia do país, no ano de 1955 (ARAÚJO, 2006).

O segundo foi a formulação dos conceitos e termos do Parque Nacional do Xingu em 1961, durante o governo do Presidente Jânio Quadros, que rompia os paradigmas envoltos na demarcação das terras indigenas. Fruto de uma luta iniciada ainda nos anos 50 e da qual participaram diversas personalidades, como Darcy Ribeiro, Eduardo Galvão e os irmãos Villas-Boas. "O Parque tinha como fundamento de sua criação a necessidade de se preservarem as condições em que viviam diversos povos indígenas da região do Xingu, incluindo o seu meio ambiente" (GOMES, 2012, p. 94).

\section{Trânsitos Interdisciplinares em Artes}


O parque corroborava como inspiração para a criação de um novo conceito durante os anos 80, a partir de novos elementos para consolidação das terras indigenas no Brasil incluindo a reprodução sociocultural dos povos indígenas. O objetivo maior era "preservar um pedaço do 'Brasil prístino', onde os índios ainda mantinham as suas culturas de forma harmoniosa com a natureza e longe da influência do chamado mundo civilizado" (ARAÚJO, 2006. p. 28: GOMES, 2012, p. 94).

Com o golpe de 1964 que se instala a ditadura militar, os militares golpistas e atuais governantes excluem veementemente a diretoria em curso na época presidida pelo médico sanitarista Noel Nutels. "Em apenas dois anos de golpe, o órgão é alvo de inúmeras denúncias de mortes, trabalho escravo, tortura, entre outras atrocidades" (GOMES, 2012, p. 100).

"O SPI extingue-se melancolicamente em 1966 em meio a acusações de corrupção e é substituido pela Fundação Nacional do Índio (Funai): a política indigenista continua atrelada ao Estado e a suas prioridades" (CUNHA, 1992, p. 16-17). Após as denúncias feitas contra o SPI o governo federal reafirmou o compromisso em penalizar legalmente todos os envolvidos e criar um órgão novo que faria tudo de modo diferente. "Mas na prática o que aconteceu foi a Funai sendo construida literalmente em cima dos escombros do SPI, visto que houve aproveitamento de funcionários, bem como de toda infraestrutura." (ARAÚJO, 2006, p. 31)

As acusações ao SPI fazem parte do documento que ficou conhecido como Relatório Figueiredo, solicitado pelo general Albuquerque Lima, na época à frente do Ministério do Interior e tinha como objetivo "[...] apurar práticas de corrupção no Serviço Nacional do Índio [...], o procurador geral Jader de Figueiredo Correia percorreu com sua equipe mais de 16 mil quilômetros, visitando 130 postos indígenas em todo o país"12.

12 STARLING, Heloisa. 5. Ditadura militar e populações Indígenas. Disponivel em: https:// www.ufmg.br/brasildoc/temas/5-ditadura-militar-e-populacoes-indigenas/. Acesso em: 25 set. 2018 .

\section{Trânsitos Interdisciplinares em Artes}


Correia (1967) constata numa das passagens do relatório que "O Patrimônio Indigena é fabuloso" E que o indígena viveria muitíssimo bem com sua própria renda, "rico e saudável nos seus vastos domínios [...]. Mas a SPI traduz fome, desolação, abandono e despersonalização do indigena." A instituição que fora criada com o objetivo de proteger os indigenas em terras brasileiras avança fortemente contra sua própria proposta, com funcionários corruptos, escravizando, maltratando e matando os povos indigenas que deveriam estar sob sua proteção institucional. "Sem ironia pode-se afirmar que os castigos de trabalho forçado e de prisão em cárcere privado representavam a humanização das relações indio-SPI" (CORREIA, 1967, p. 3; 9).

No artigo 129, da CF de 1934, incluem pela primeira vez na história brasileira numa constituição os indígenas, mas aparece timidamente apenas versando sobre sua relação com as terras que habitavam "Será respeitada a posse de terras de silvícolas que nelas se achem permanentemente localizados, sendo-lhes, no entanto, vedado aliená-las" (GOMES, 2012, p. 96; 98). Verifica-se que nas sequentes promulgações das Constituições de 1937 (a outorgada) e de 1946 (a liberal-democrata) reafirmam as mesmas prerrogativas e de alguma forma demonstrando a proeminência da consolidação dos direitos dos povos indígenas.

Gomes (2008, p. 434-435) afirma que, a partir da CF. de 1934, até a atual de 1988, há uma abordagem positiva dos povos indígenas, fazendo-se presente o reconhecimento de suas culturas e seus territórios. Foram considerados cidadãos de direitos específicos e respaldo do Ministério Público. "Nas disposições transitórias, todas as terras indígenas deveriam estar demarcadas no prazo de cinco anos, isto é, até outubro de 1993."

A Funai foi criada logo após a extinção do SPI, no dia 5 de dezembro de 1967 e tinha a incumbência institucional de resolver a questão indigena de uma vez por todas. Isso significaria, efetivamente, transformar os índios em brasileiros, integrá-los à nação e assimilá-los culturalmente ao seu povo. Foi a partir do

\section{Trânsitos Interdisciplinares em Artes}


artigo 198 da CF de 1967 que foi elaborado o Estatuto do Índio que é uma "regulamentação da legislação brasileira sobre os índios, em seus aspectos jurídicos e administrativos" (GOMES, 2012, p. 101).

Podemos dividir sua atuação em dois tempos: período da ditadura militar e a partir de 1985. numa perspectiva democrática. Desta feita, é quase que obrigatório que exista diferenças abissais entre os dois períodos. O balanço da fase militar é muito mais negativo que positivo, iniciando-se, digamos, oficialmente os interesses "anti-indigenas" que eram sempre de inferior importância ao dos interesses fundiários, políticos ou militares (GOMES, 2012; MELATTI, 2014).

Gomes (2012, p. 110) traz uma crítica mais reflexiva a respeito dessa participação das Organizações Não Governamentais (ONGs), afirmando que a Funai tem sido um "órgão mais vilipendiado do que admirado, especialmente pelas ONGS de cunho indigenista que surgiram com a pretensão de não somente guiar, mas também sobrepor-se às ações estatais", mostrando-se com uma voz mais ecoante que a própria Funai e nos convida a reflexões mais profundas sobre tais atuações.

Com o final da ditadura, a Funai adentra ao periodo da democracia, mas com um governo fortemente com tendências patronais, Sarney adotou uma atitude opressiva, contrária ao movimento indigena e aos indigenistas, tendo inclusive abolido o curso de indigenismo que era dado durante o periodo ditatorial para os novos serviços do quadro (GOMES, 2012).

Porém, mesmo com a resistência do governo Sarney em incluir os indigenas nas políticas nacionais, em 1988, foi promulgada a Constituição Cidadã, que foi antecedida por forte mobilização e organização de defensores da questão indigena, bem como os próprios indígenas num movimento composto, ainda, de antropólogos, das ONGs laicas e religiosas e da Associação Brasileira de Antropologia. Dessa feita, obteve-se concretamente a inclusão de dois artigos garantidos e introduzidos sobre os povos indigenas, sendo eles os artigos 231 e 232 (GOMES, 2012).

\section{Trânsitos Interdisciplinares em Artes}


art. 231 traz uma significativa mudança quando inclui a terra como direito originário, ou seja, é uma reafirmação de que indígenas já estavam aqui de quando ocorreu a invasão. Diante disso e com esse argumento, alguns povos indigenas conseguiram a demarcação de terras sob a alegação do direito originário como "carro-chefe" da argumentação. O Supremo Tribunal Federal peca ao exaurir uma súmula com diversas observações a respeito dos consagrados direitos indígenas, sendo que "a data da promulgação da CF [...] seria o tempo legal em que um grupo indígena necessitaria estar ocupando uma determinada área para ela ser considerada 'tradicionalmente ocupada'" (GOMES, 2012, p. 111).

Entramos na celeuma do que seria cidadania indígena e se ela realmente existiria. Leva-se em consideração que direitos foram garantidos na CF de 1988, sendo "reconhecidos sua organização social, costumes, línguas, crenças e tradições", como dos próprios territórios indígenas e sua utilização total de recursos. Gomes (2008) afirma que:
Considerando, por sua vez, que o Brasil continua submetido a um domínio multifacetado neocolonialista, e que o sistema social brasileiro é extremamente desigual e opressor das camadas sociais populares, à margem das quais se situam os povos indigenas, podemos aquilatar a dupla opressão que sofre o índio como individuo, em seus direitos políticos, sociais e culturais. Assim, perante a humanidade, o indio desponta, na atualidade, como vítima da vítima (GOMES, 2008, p. 420).

Que sujeito é esse construido e reconstruido ao longo da história? Que vai de mocinho a vilão em menos de duas linhas na própria história construída pelos homens brancos do seu próprio território? Como esse índio se constitui e resiste aos ataques das mais variadas formas, seja pela palavra ou efetivamente pela "guerra justa" ou, ainda, privado do seu nomadismo ao serem aprisionados nas aldeias criadas pelos mais variados gestores ao longo da história? Em cada época da história aqui retratada, mesmo que minimamente, traz muitas reflexões sobre o indigena, os povos

\section{Trânsitos Interdisciplinares em Artes}


indigenas, seus direitos, seus territórios, as violações vivenciadas em todos os aspectos mais opressos imaginados, é uma história apodrecida, enfestada de ratos nefastos.

O caminho para a consolidação da cidadania para os índios é ainda longo e áspero, mas não irreal. A garantia de suas terras, a consolidação de seu crescimento demográfico, a integração social e a participação política ao Brasil, com autonomia cultural, e ainda o fortalecimento de suas economias são estágios a serem vencidos, passo a passo e concomitantemente. É um caminho em que os demais brasileiros devem dar a mão aos índios, com a consciência posta de que algo de bom resultará dessa união (GOMES, 2008, p. 441).

Entendemos que o discurso de minorar o indígena se compõe historicamente por meio da subjugação imputada a eles ao longo da história de constituição do continente brasileiro, no qual se inicia logo no periodo colonial, quando ele é acusado de vadiagem. por se recusar à escravidão destinada a eles. Os elementos utilizados em primazia decorrem sempre da premissa do acúmulo de capital, ou seja, os indigenas sempre estiveram na contramão desse processo neocapitalista concretizado nos dias atuais.

Os indigenas nunca entenderam nossa necessidade em acumular coisas, comprar utensilios que eles consideram inúteis. A vivência indígena é muito diversa e singular, completamente diferente da nossa, o indigena está no presente, ele vive o momento, experiencia em sua essência o que os momentos podem trazer para sua vida. E alguém que vive sem querer acumular. sem interesses econômicos baseados no sistema capitalista não conseguiria conviver entre nós, os ktâwanõ.

Mesmo se vendo obrigados a trabalhar na sociedade envolvente, mesmo com alguns conflitos geracionais perceptiveis, ainda predomina o respeito aos mais velhos que eles chamam de "ancião". Os saberes e vivências desse povo, destoam dos nossos modos de viver e assim sendo é mais fácil subjugá-los, tentando inferiorizá-los, tal qual como aconteceu ao longo de toda história do Brasil, do que mostrar as qualidades existentes nos povos indigenas,

\section{Trânsitos Interdisciplinares em Artes}


sua cultura diversificada, sua culinária, seus artesanatos, a forma como lidam com os recursos naturais, com tudo que envolve sua vivência diária.

A sociedade envolvente precisa respeitar a diversidade e pluralidade indígena, para que a história escrita sob o sangue desse povo possa, de alguma maneira, tornar-se presente no discurso coletivo, abandonando assim as amarras colonialistas às quais se prendem grande parte da sociedade envolvente. Conhecer, respeitar e usufruir das benesses que os indigenas trazem diariamente na conservação do meio ambiente serviria de lição a todos nós, se conseguíssemos efetivamente enxergar o quê de fato acontece ao nosso redor.

\section{Referências}

ALENCASTRO, Luiz Felipe de. 0 trato dos viventes: Formação do Brasil Atlântico Sul nos séculos XVI e XVII. 6. ed. São Paulo: Companhia das Letras, 2000.

ARAÚJO, Ana Valéria et al. Povos Indígenas e a Lei dos "Brancos": o direito à diferença. Brasilia: Ministério da Educação. Secretaria de Educação Continuada, Alfabetização e Diversidade: LACED/Museu Nacional, 2006.

BETTENCOURT, Lucia. Cartas Brasileiras: Visão e Revisão dos Índios. In: DONISETE, Luís; GRUPIONI, Benzi (Org.). Índios no Brasil. 4. ed. São Paulo: Global: Brasilia: MEC, 2000. p. 39-46.

BOSI, Alfredo. Dialética da colonização. São Paulo: Companhia das Letras, 1992. CHAUI, Marilena de Souza. 500 anos - Caminhos da Memória, Trithas do Futuro. In: DONISETE, Luís; GRUPIONI, Benzi (Org.). In: Índios no Brasil. 4. ed. São Paulo: Global: Brasilia: MEC, 2000. p. 11 e 12.

CORREIA, Jader de Figueiredo. Relatório Figueiredo. 3 de novembro de 1967. Ministério do Interior, Brasília: 1967.

CUNHA, Manuela Carneiro. Introdução a uma história indígena. In: CUNHA, Manuela Carneiro Cunha. (org). História dos Índios no Brasil. São Paulo: Companhia das Letras: Secretaria Municipal de Cultura: FAPESP. 1992. p. 9 a 24.

\section{Trânsitos Interdisciplinares em Artes}

Bárbara Tavares dos Santos, Liliane Scarpin S. Storniolo, Renata Patricia da Silva (Organizad 
GOMES, Mércio Pereira. O caminho brasileiro para a cidadania indígena. In: PINSK, Jaime: PINSKY, Carla Bassanezi (Orgs.). História da Cidadania. 4. ed. 2. ed. São Paulo: Contexto, 2008

GOMES, Mércio Pereira. Os índios e o Brasil: passado, presente e futuro. São Paulo: Contexto, 2012.

MELATTI, Julio Cezar. Índios do Brasil. 9. ed. São Paulo: Editora da Universidade de São Paulo, 2014

PERRONE-MOISÉS, Beatriz. Índios livres e índios escravos: os princípios da legislação indigenista do período colonial (séculos XVI a XVIII). História dos Índios no Brasil. São Paulo: Companhia das Letras: Secretaria Municipal de Cultura: FAPESP, 1992. p. 115 a 132
RAMOS, Alcida Rita. Sociedades Indígenas. 2. ed. São Paulo: Editora Ática, 1988. 96p

RIBEIRO, Darcy. O povo brasileiro: a formação e o sentido do Brasil. 3. ed. São Paulo: Global, 2015

RIBEIRO, Darcy. Os indios e a civilização: a integração das populações indigenas no Brasil moderno. 7ª. ed. São Paulo: Global, 2017.

\section{Trânsitos Interdisciplinares em Artes}

Bárbara Tavares dos Santos, Liliane Scarpin S. Storniolo, Renata Patricia da Silva (Organizadoras 


\section{Habitações Lúdicas: \\ O Fazer Teatral com as Crianças do Povoado Itaúba - TO}

Renata Patrícia da Silva ${ }^{1}$ Carminda Mendes Andréz

1 Profa. do Curso Licenciatura em Teatro - Universidade Federal do Tocantins (UFT). Doutora em Artes pelo DINTER UNESP/UFT, e-mail: renatapatricia@uft.edu.br.

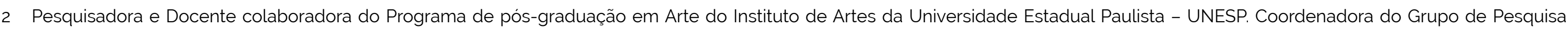
Performatividades e Pedagogias Cnpq. Coordenadora da Instituição Promotora do DINTER entre UNESP e UFT (2016-2019).

\section{Trânsitos Interdisciplinares em Artes}

Bárbara Tavares dos Santos, Liliane Scarpin S. Storniolo, Renata Patricia da Silva (Organizadoras) 
Numa temporalidade distinta, que me abrigava com um abraço carinhoso, Mangueiras ${ }^{3}$ ensinava-me no corpo um fazer docente tático. Para essa ação, contei com a ajuda de um parceiro que me acompanhava naquela visita à Augustinópolis: Seu Zé Roberto4, que participou de todo processo de construção das casinhas. A colheita dos bambus e das palhas 5 foi realizada por mim e Zé Roberto, na comunidade Itaúba, durante o período da manhã, já que o início do trabalho com as crianças ocorreria no turno da tarde. Ao retomar a memória desse momento, lembro-me do carro oficial carregado de palhas e bambus, expressando a desconstrução proposta por nossa ação, bem como a (re)significação do veículo acerca da oficialidade e função que lhe era atribuida.

3 Escola Municipal Mangueiras, localizada no Povoado de Itaúba, na cidade de Augustinópolis, interior do estado do Tocantins. O nome atribuido à instituição é fictício, para preservar sua identidade. A escolha do nome "Mangueiras" se deu pela abundância de mangueiras na comunidade e também no terreiro da escola.

4 Motorista do Setor de Transportes da Universidade Federal do Tocantins. O nome atribuído ao participante é fictício para preservar a sua identidade.

5 Folhas de buriti.
Imagem 1 - Carregamento das palhas realizado por Seu Zé Roberto. Foto: Renata Patrícia. Acervo pessoal da pesquisadora.

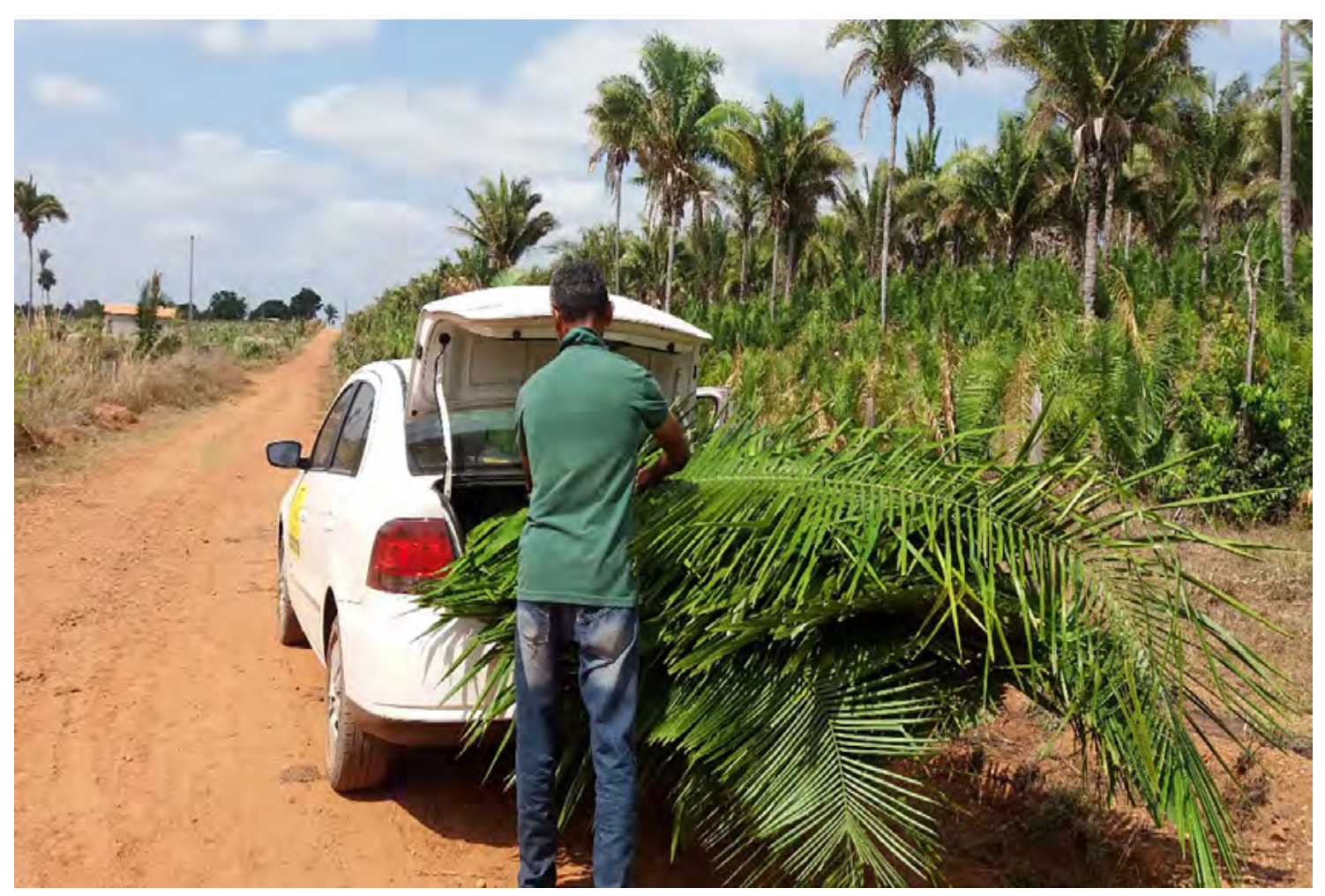

\section{Trânsitos Interdisciplinares em Artes}

Bárbara Tavares dos Santos, Liliane Scarpin S. Storniolo, Renata Patricia da Silva (Organizadoras) 
Quando enchemos o carro de bambus e palhas, partimos em direção à Escola Municipal Mangueiras para descarregar o material. Chegamos no horário do recreio da manhã, o que causou certa curiosidade, acompanhada de muitas perguntas feitas pelas crianças. Como se trata de uma pequena comunidade rural, todas as crianças já sabiam do trabalho que estava sendo realizado com os alunos da professora Darleni ${ }^{6}$ no turno da tarde. Diante disso, alguns meninos e meninas do Ensino Fundamental pediram para participar da construção das casinhas junto com os pequenos da Educação Infantil. Considerando a proposta de assumir minha prática em Mangueiras como ato performativo, compreendi que manter o espaço aberto para os possiveis encontros e

6 O trabalho na Escola Municipal Mangueiras aconteceu em parceria com a professora Darleni, egressa do Curso de Licenciatura em Teatro da UFT (PARFOR), que viabilizou a realização do projeto na escola. Nossas ações foram realizadas com a turma da Educação Infantil, crianças de 04 e 05 anos, pela qual a professora estava responsável no periodo de realização da pesquisa. Ressaltamos que todos os nomes atribuídos aos participantes da pesquisa, neste texto, são fictícios, para preservar suas identidades. compartilhamentos constituía o processo. Então, era melhor caminharmos juntos e compartilhar a experiência de uma ação em constante movimento e sujeita a riscos.

Ao retornar, no período da tarde, quando eu e a professora Darleni chegamos à sala de aula, vimos uma sala cheia de crianças, entre elas, os pequenos da sua turma e os maiores, que estudam no período da manhã, e retornaram para a escola. Antes de sairmos da sala, falamos sobre a proposta da construção das casinhas e seguimos para o terreiro para ajudar Seu Zé Roberto com a construção. Chegando lá, as crianças carregaram algumas palhas e bambus para perto de onde estava sendo construida a primeira casinha. Ao observarem Seu Zé trabalhar na colocação das palhas, os meninos do $5^{\circ}$ ano, apontaram contribuições acerca da colocação dos bambus e amarração das palhas, para que ficassem mais firmes e durassem mais tempo, demonstrando que também sabiam construir casinhas. Logo, solicitamos que nos ajudassem com as demais, a fim de agilizar a construção das três casinhas no terreiro.

\section{Trânsitos Interdisciplinares em Artes}


Imagem 2 - Crianças ajudando na construção das casinhas. Foto: Renata Patrícia. Acervo pessoal da pesquisadora.

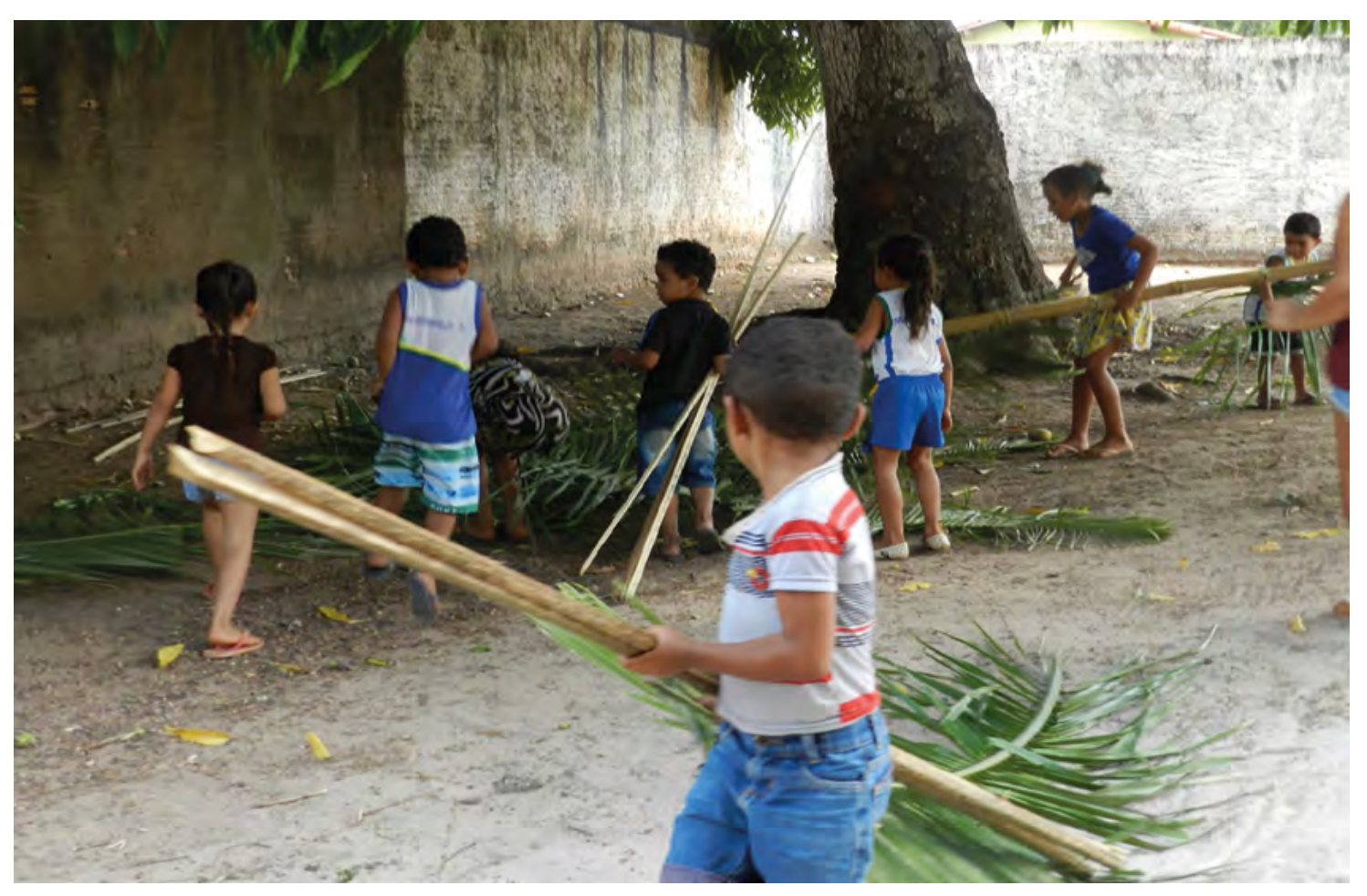

Quando a primeira casinha ficou pronta, uma correria envolveu o espaço. De repente, Jhon, um dos meninos pequenos, transformou-se em lobo e, soltando um grito, com as duas mãos na altura do peito, como se fossem garras, foi assombrar os moradores da casinha, que sairam correndo e gritando desesperados. 0 movimento de assombrar, correr, entrar e sair repetiu-se por algumas vezes e depois o grupo dispersou-se

Ao lado, deitado em pedaços de palha, um menino se aconchegou, como se dormisse. Ele permaneceu assim por um tempo. Algumas crianças o observaram por um tempo e saíram. Logo em seguida o garoto também se levantou e correu pelo terreiro. Algumas crianças se aproximaram e usaram os mesmos pedaços de palha para forrar o chão da casinha pronta.

Nesse momento, ainda faltavam cobrir duas casinhas, mas a palha havia chegado ao fim. Sendo assim, combinamos que fariamos uma colheita coletiva pela comunidade. Mas, antes que eu terminasse de falar, vi aquele monte de meninos e meninas disparados pela estrada afora em direção ao carro, onde estava Seu Zé Roberto, que se adiantou no trabalho de cortar as palhas. Cada criança pegou uma palha e voltamos para a escola. Era bonito ver

\section{Trânsitos Interdisciplinares em Artes}

Bárbara Tavares dos Santos, Liliane Scarpin S. Storniolo, Renata Patricia da Silva (Organizadoras) 
a estrada cheia de garotos e garotas carregando as palhas verdes. Corpos que corriam pela terra vermelha, rabiscando contornos na paisagem de Itaúba.

Imagem 3 - Crianças pela estrada durante a colheita das palhas pelo Povoado Itaúba. Foto: Renata Patrícia. Acervo pessoal da pesquisadora.

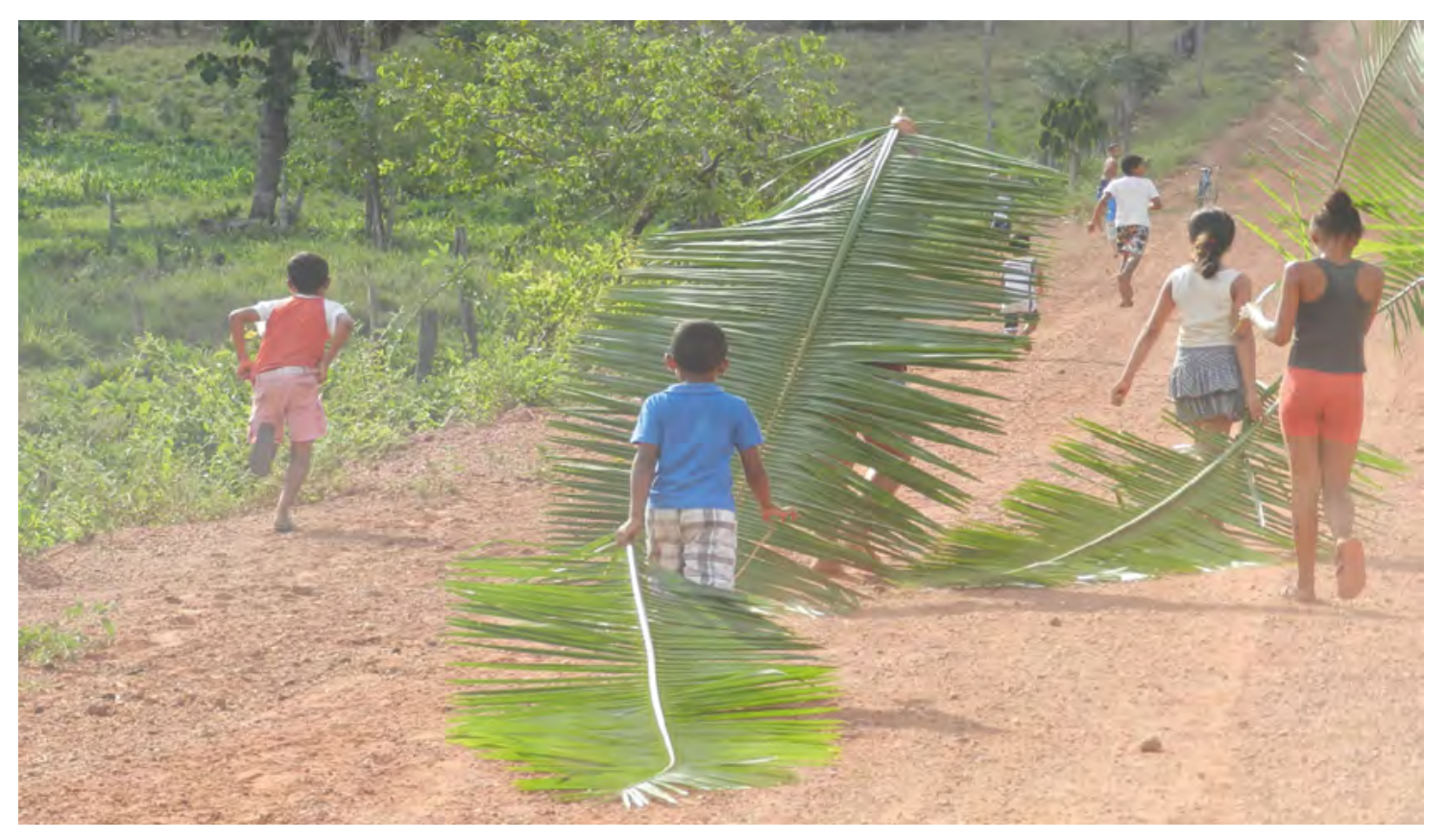

A criação das casinhas no terreiro da escola foi uma ação que possibilitou às crianças diferentes apropriações daquele espaço, tanto nas práticas do Teatro, quanto em seus feitos cotidianos. Por isso, aproveitei o espaço para possibilitar que as crianças se apropriassem dele, utilizando objetos e brinquedos levados por mim, disponiveis no espaço da escola e, também. trazidos por elas. As crianças habitavam o terreiro e se apropriavam das casinhas e do ambiente à sua volta, bem como dos objetos que encontravam.

Meninas e meninos organizavam as pequenas casas, colocando panos para forrar o chão ou para servir de porta. Caixas transformavam-se em mesinhas para a cozinha, onde preparavam o café que seria servido aos amigos que estavam esperando. Enquanto isso, outras crianças limpavam a casa com uma vassoura e penduravam coisas no teto, para deixá-la mais bonita e aconchegante para o café da tarde com os amigos.

Na casa ao lado, meninas brincavam de boneca, penteando seus cabelos. Ao fundo, havia uma mesinha com

\section{Trânsitos Interdisciplinares em Artes}

Bárbara Tavares dos Santos, Liliane Scarpin S. Storniolo, Renata Patricia da Silva (Organizadoras) 
esmaltes, batom e uma cadeira. Ali fora construido um espaço de encontro da beleza de meninas e bonecas.

Imagem 4 - A casinha de meninas e bonecas. Foto: Renata Patrícia. Acervo pessoal da pesquisadora.

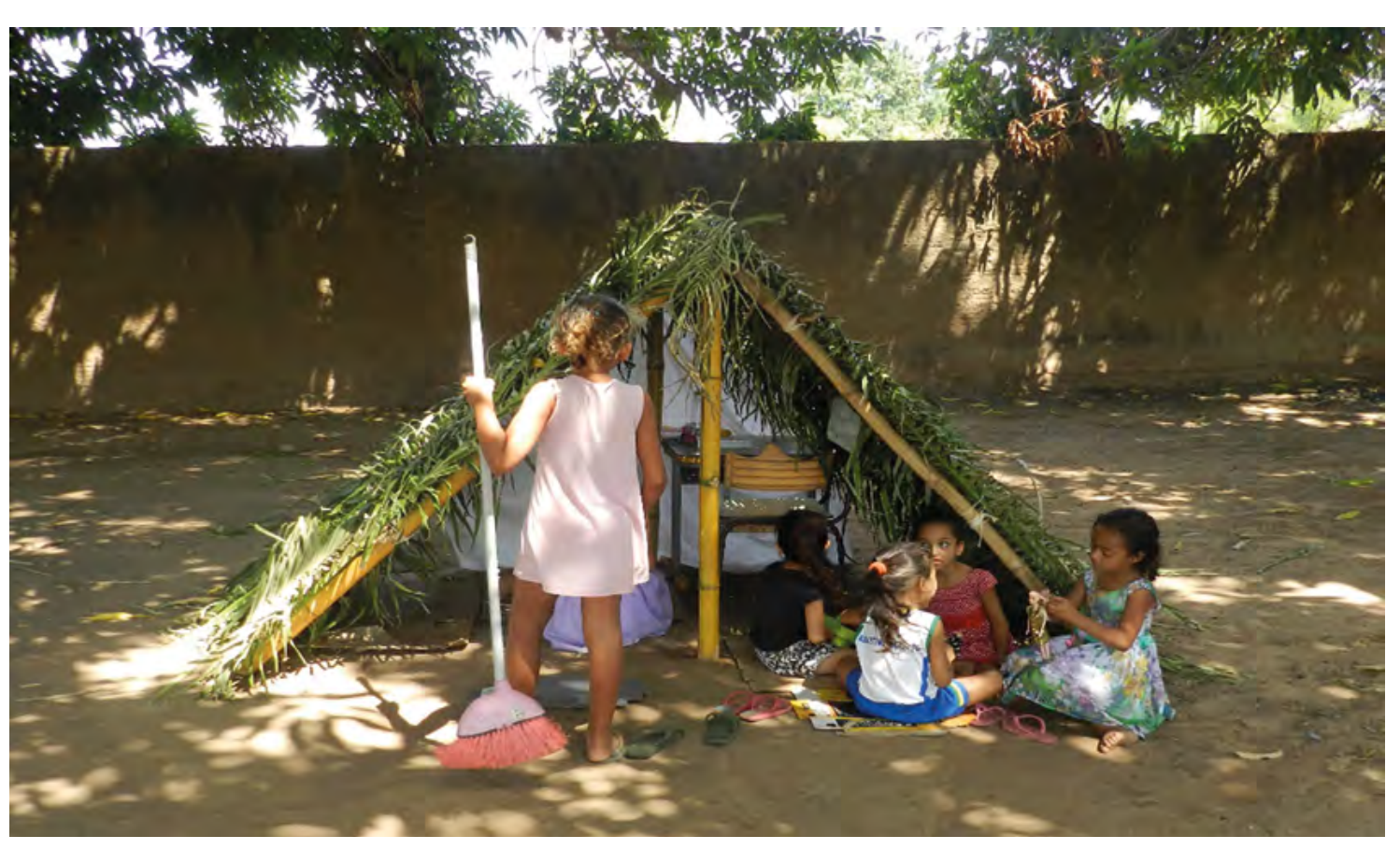

Maria caminhava pelo terreiro com um escorredor de arroz na cabeça, procurando um lugar para morar. Ao encontrar-me, disse que não tinha uma casa. Disse-lhe então, que precisava morar junto com alguns colegas, pois não tínhamos casinhas individuais. Ela voltou a procurar algum grupo que pudesse acolhê-la e, depois de dar duas voltas pelo terreiro, entrando e saindo de todas as casinhas, encontrou abrigo em uma delas.

Jhon chamou-me para vê-lo colocar portas de palha em sua casa. Ele dizia: "Tia, vai ficar muito bonito!" (Terminando de colocar). "Olha tia, olha aqui, como ficou bonito!" Antes que eu the respondesse, outro garoto (Gilsinho) veio correndo e gritando na nossa direção, fazendo uivos de lobo: um grupo de meninos correu para dentro da casinha; outro saiu pelo terreiro; e outro garoto se transformou em lobo. O movimento de perseguição do grupo, que gritava, corria, entrava e saía da casa repetiu-se por algumas vezes, até que eles se desentenderam porque todos queriam ser lobos, e o grupo dispersou-se.

\section{Trânsitos Interdisciplinares em Artes}

Bárbara Tavares dos Santos, Liliane Scarpin S. Storniolo, Renata Patricia da Silva (Organizadoras) 
Enquanto isso, algumas crianças retornavam às casinhas e apenas sentavam- se lá dentro. Outras se agregavam aos demais grupos espalhados pelo terreiro. Havia também algumas que encontravam outros materiais e iniciavam outras relações.

Observo um grupo que se apropria da cavadeira utilizada por Seu Zé Roberto na construção das casinhas. Mário a utiliza para cavar um buraco no terreiro, enquanto outros garotos o observam. Um deles comenta: "ele já sabe trabalhar!". Me aproximo do grupo, o buraco onde está cavando, é próximo ao muro da escola e já vinha sendo feito pelas crianças há algum tempo. Mário me diz que ali será a casa de um cachorro. Entre os observadores, Gilsinho se ajoelha e começa a latir. Em seguida, tenta entrar no buraco, e começa a cavar com as patas, como se quisesse se aconchegar ali. Então, Jhon pega um pedaço de bambu e ajuda o cachorro. Entra terra no olho do cachorro e Gilsinho sai chorando em direção à Profa Darleni. Enquanto isso, junto ao grupo de garotos, converso com Jhon, que ficou chorando também.
Imagem 5 - Meninos brincando no terreiro da Escola. Foto: Renata Patrícia. Acervo pessoal da pesquisadora.

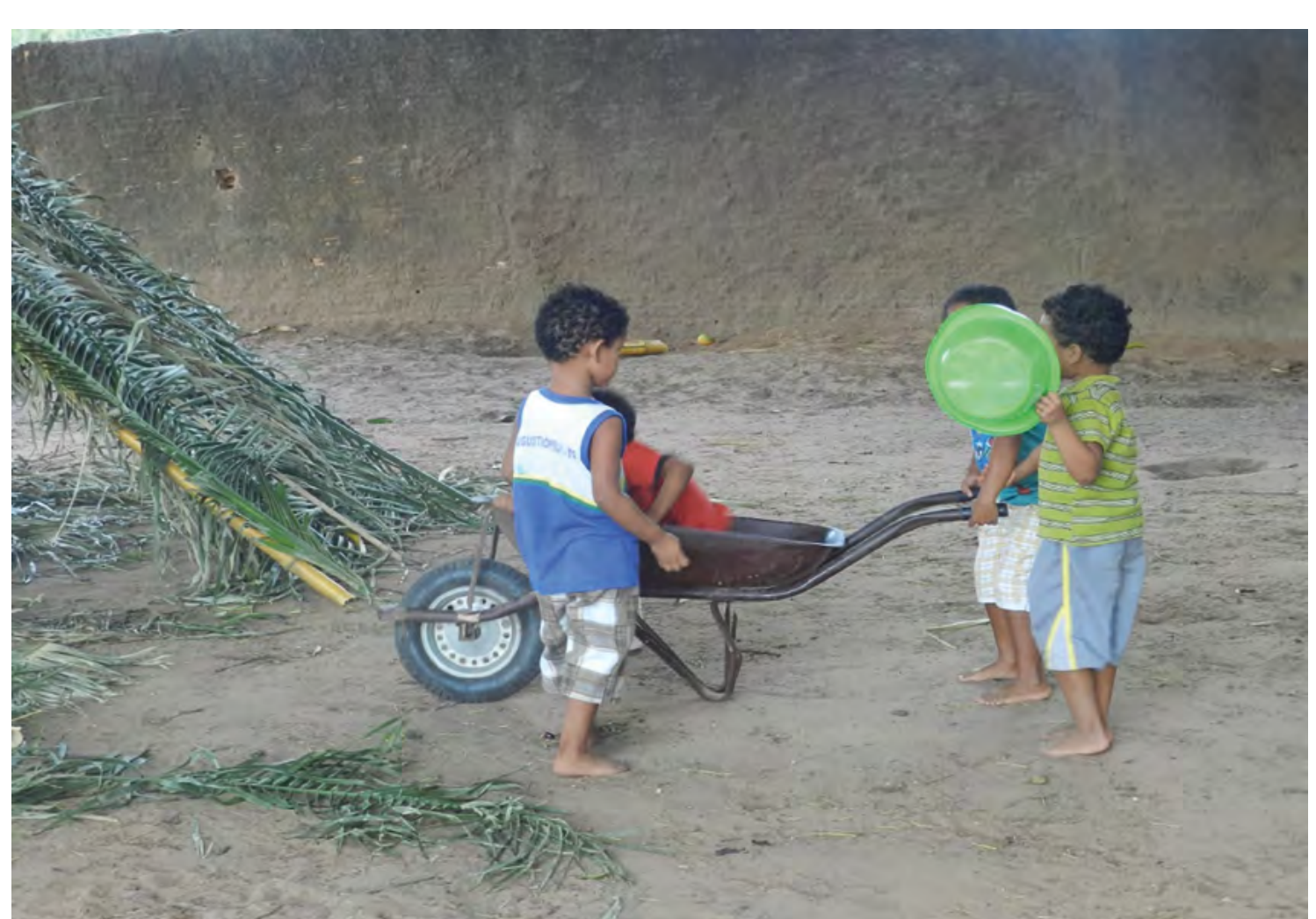

\section{Trânsitos Interdisciplinares em Artes}

Bárbara Tavares dos Santos, Liliane Scarpin S. Storniolo, Renata Patricia da Silva (Organizadoras) 
Nossos primeiros olhares para Mangueiras e o encontro com as pessoas de lá despertaram reflexões acerca dos lugares da escola, da ação docente, da turma de crianças e quais (im)possibilidades poderiam surgir ao longo do caminho. Diante disso, buscamos nos saberes compartilhados, encontrar possibilidades para criar um teatro da escola. Dessa forma, a proposta tinha como objetivo possibilitar ações que fomentassem a criação de espaços na escola, de forma lúdica e poética, proporcionando percursos dentro e fora da sala de aula. Tais ações buscavam desvios no cotidiano escolar, criando intervenções em seus espaços que provocassem o envolvimento de todos os praticantes do cotidiano de Mangueiras.

A Escola Municipal Mangueiras está localizada na Zona Rural, no Povoado Itaúba, Município de Augustinópolis. São apenas $5 \mathrm{~km}$ da cidade, por um caminho entre rodovia e estrada de terra. A instituição funciona nos turnos matutino e vespertino, atendendo crianças de 04 a 10 anos na Educação Infantil e Ensino Fundamental do $1^{\circ}$ ao $5^{\circ}$ ano, com turmas multisseriadas. As crianças atendidas pela instituição são pertencentes às familias residentes no Povoado Itaúba e nas proximidades, cuja sobrevivência advém do trabalho agricola e a maioria não possui renda fixa (SECRETARIA MUNICIPAL DE EDUCAÇÃO, 2017).

Na ação que narramos anteriormente, a intenção foi criar intervenções no ambiente, possibilitando momentos de encontro e compartilhamento de saberes-fazeres coletivos, além de estimular outras possibilidades de uso do espaço institucional. Para tanto, propusemos a construção de cabanas de bambu e palha de buriti no terreiro da escola. A inspiração das cabanas, que chamamos de casinhas, veio das casas da comunidade, que são cobertas de palha de buriti e feitas de pau a pique.

Uma das fontes que nos inspirou à realização da ação em Mangueiras foram os escritos de Marina Marcondes Machado que, ao trazer o conceito de ato performativo, ampliou o campo de discussão a respeito do fazer teatral com crianças pequenas. Na perspectiva da autora, os atos performativos podem ser constituidos por momentos preparados pelo adulto ou por relações

\section{Trânsitos Interdisciplinares em Artes}


que as crianças estabelecem em espaços e tempos, podendo também ser relações compartilhadas entre adultos e crianças em âmbitos artístico-existenciais? ${ }^{7}$. Sendo assim, os atos performativos são compostos por experiências relacionais, geradas por compartilhamentos coletivos (MARCONDES, 2015). Dessa forma, crianças e adultos, nos atos performativos, exercem suas ações enquanto performers, como proposto pela autora:

A criança performer é seu corpo total, sua corporalidade: ela é móvel, plástica, modelável: polimorfa; seu repertório é rico em teatralidade e musicalidade, nos sentidos

7 Marina Marcondes Machado concebe quatro âmbitos artístico-existenciais: musicalidade, teatralidade, corporalidade e espacialidade. Para a autora: "é conveniente que os termos fiquem no plural, uma vez que não se definem como únicos: há multiplicidade de noções para os possiveis principios norteadores destes campos". [...] Como 'âmbito artístico existencial', nossa musicalidade acontece desde a escuta da sonoridade da barriga da mãe, a teatralidade é dada por gesto e palavra dos adultos ao meu redor, a corporalidade é meu "eu" (ser no mundo) e a espacialidade fetal, nem se diga!... Experiências iniciais comuns a todos nós e que se expandem com o nascimento e com o convite para a vida (MACHADO, 2015, p. 55) contemporâneos dos termos: ela improvisa, ela encarna emoções em seu corpo, ela é capaz de fazer-se partitura enquanto usufrui a paisagem sonora dos lugares em que está etc. E sua capacidade de uso do espaço tornam presentes as noções de instalação, happening e performance, tão caras às artes visuais hoje (MARCONDES, 2015. p. 59)

A autora ainda faz uma aproximação entre o ser e estar da criança e a cena contemporâneå ${ }^{8}$ Seu conceito de criançaperformer convida-nos a desconstruir a concepção do faz de conta enquanto representação e possibilita lidar com a efemeridade do brincar infantil, que se modifica sem seguir uma lógica formal.

8 "Hoje a cena contemporânea não faz distinção entre teatro e dança, entre encenações teatrais e contações de histórias e leituras dramáticas, entre teatro e performance" (MACHADO, 2010, p. 118). Para pensar o campo do fazer teatral, tomamos como referência o conceito de Teatro Pós-Dramático definido por Hans-Thies Lehmann. Em seu livro: Teatro Pós-Dramático (2007), o autor analisa diferentes manifestações artísticas que se situam em territórios hibridos das artes visuais, música, dança, cinema e performance.

\section{Trânsitos Interdisciplinares em Artes}


Nesse sentido, no âmbito do fazer teatral na educação, há também o adulto performer, par relacional da criança performer.

Não é sinônimo para o artista/performer profissional; utilizo o termo performer tal como os cientistas sociais e antropólogos fazem - performar é agir deste ou daquele modo, é "ser o que se é", é compreender a multiplicidade de papéis sociais que nos cabem. Neste sentido, todos os adultos que lidam com crianças podem ser considerados adultos performers

Minha proposta é o (auto) conhecimento e diversificação de atitudes, em nome do agachamento como principal conduta frente às crianças pequenas; então, sim, haveria um adulto performer a ser elaborado, desenhado ou esboçado, na corporalidade do professor pesquisador aquele que se agacha (MARCONDES, 2015, p. 55).

O conceito de criança performer advém de seus estudos da Fenomenologia de Merleau-Ponty, principalmente da ideia de corporalidade. "A corporalidade é uma noção central para compreen- der e realizar uma fenomenologia das relações da criança consigo mesma, com o outro e com o mundo" (MARCONDES, 2010a, p. 35). Outra referência para a autora são os escritos do psicanalista inglês D. W. Winnicott, que desenvolveu estudos sobre o brincar e as formas da criatividade humana. Aliado a esses pesquisadores, a autora traz os estudos de Manuel Jacinto Sarmento, sobre a sociologia da Infância, e de Victor Turner, a respeito da Antropologia da Performance ${ }^{9}$

A proposta de Marina Marcondes para pensar o teatro com crianças vai à direção de um fazer pautado nas relações e valorização da experiência compartilhada, criando tempos e espaços em que elas possam descobrir-se e ao mundo, inventando suas próprias histórias, sem que haja um direcionamento imposto pelas estratégias de um olhar adulto. Imerso/a nesse movimento, o professor/a exerce uma posição de presença-ausência, uma ação tática, sem nutrir expectativas prévias diante do processo junto às crianças.

9 Cf. Machado (2010)

\section{Trânsitos Interdisciplinares em Artes}

Bárbara Tavares dos Santos, Liliane Scarpin S. Storniolo, Renata Patricia da Silva (Organizadoras) 
Ao refletir essas experiências, consideramos que os acontecidos que se deram em "Habitações Lúdicas" poderiam ser compreendidos como propositores de espaços e tempos, nos quais as crianças exploravam seus fazeres. Nesse processo, um dos aspectos importantes foi atentar para a posição da pesquisadoraobservadora das relações que as crianças estabeleciam com e naqueles espaços. Isso possibilitou contemplar a teatralidade daqueles movimentos suscitados pelas propostas da aula de teatro, a fim de compreender esse teatro da escola.

Na posição de observadoras, percebemos o quanto nossa interferência no jogo das crianças direciona seus fazeres para um contexto mais dramático, exigindo que suas criações caminhem para a linearidade do planejamento. Imersas na realidade de Mangueiras, fomos convocadas a tal postura nas atividades de teatro com crianças pequenas. Por isso, buscamos adotar uma postura mais participativa diante delas, a fim de apreciá-las e acolhê-las quando solicitadas. A ação docente junto aos pequenos/ as fez-nos perceber que nossa intervenção em suas brincadeiras deveria acontecer por meio da proposição de espaços e não no direcionamento de suas atividades, a fim de compreendê-las como protagonistas das ações que estavam acontecendo.

Portanto, pensar uma aula de teatro como ato performativo corrobora com um pensamento que vimos explorando a certo tempo, de que o fazer teatral pode ser um espaço provocador de experiências compartilhadas entre os praticantes do espaço escolar, possibilitando a observação de uma teatralidade cotidiana na ressignificação do espaço da escola. Isso posto, consideramos que a experiência do cotidiano compartilhado com as crianças, suas apropriações na/da escola e o brincar que inventa espaços e desvios provocou a compreensão de que privilegiar o protagonismo das crianças é assumir que algumas coisas não se ensinam. Nesse sentido, na busca por um teatro da escola, fomos convocadas a desaprender alguns princípios, como escreveu Manoel de Barros (2013).

\section{Trânsitos Interdisciplinares em Artes}


Por um teatro da escola: a ação tática no/do cotidiano

Este artigo foi constituido por recortes de narrativas caminhantes, tendo como objetivo resgatar momentos vivenciados ao longo da pesquisa desenvolvida no Doutorado Interinstitucional UNESP-UFT, no qual a proposta de investigar um teatro da escola, partindo da compreensão de uma docência como ação tática, possibilitou o desenvolvimento de uma pesquisa inquieta, que buscou não se fixar em um lugar único, mas traçar caminhos outros, ativar encontros e ocupar espaços ${ }^{10}$.

Para fomentar a discussão de um teatro da escola recorremos a autores que nos possibilitaram pensar a docência

10 Tese de Doutorado defendida pela autora Renata Patricia da Silva, intitulada: "Por um teatro da escola: táticas e menoridades ao rés do chão", sob orientação da Profa. Dra. Carminda Mendes André, no Programa de pós-graduação em Artes da Universidade Estadual Paulista - UNESP. O conteúdo parcial da tese pode ser acessado no Repositório Institucional da UNESP, no seguinte link: http://hdl.handle.net/11449/183424. enquanto processo de experiência compartilhada no/do cotidiano. Nesse sentido, concordamos com a reflexão de Jorge Larrosa, a respeito do entendimento da educação a partir do par "experiência/ sentido". Segundo o autor: "[...] a experiência é o que nos passa, o que nos acontece, o que nos toca. Não o que se passa, não o que acontece, ou o que toca" (LARROSA, 2017, p. 18). Sendo assim, consideramos que, para compreender o espaço da escola, a ação docente precisa permitir-se aos atravessamentos da realidade na qual se insere, a fim de construir ações entrelaçadas com as práticas e os sujeitos que atuam nesse espaço. Ainda assim. compreender o que vem a ser uma docência tática, contaminada pelos seus acontecimentos cotidianos, não é apenas um objetivo que se escreve numa folha em branco. Como nos diz Certeau: "para ler e escrever a cultura ordinária, é mister reaprender operações comuns e fazer da análise uma variante do seu objeto (2013, p. 35)". Por isso, a narrativa que aqui trouxemos, para elucidar o que chamamos de ação tática docente, esboça um pouco desse

\section{Trânsitos Interdisciplinares em Artes}

Bárbara Tavares dos Santos, Liliane Scarpin S. Storniolo, Renata Patricia da Silva (Organizadoras) 
processo de desconstruir-se professor/a no/do cotidiano escolar, assumindo os riscos, as (im)possibilidades e deixando-se atravessar pelos fazeres ordinários.

Nesse sentido, a discussão a respeito de um teatro da escola está atrelada à compreensão de que a instituição escolar é um território no qual se inscrevem diferentes saberes-fazeres, uma vez que é marcada pela institucionalização do poder disciplinar, que the confere certa organização, normas e um modelo de funcionamento. Por outro lado, é constituída pelos sujeitos que a habitam e, nas relações que tecem no/do/com o lugar institucionalizado produzem suas práticas cotidianas e inscrevem seus saberes ordinários. Para fomentar essa consideração, recorremos à Michel de Certeau, quando diz que:

Uma sociedade seria composta de certas práticas exorbitadas, organizadoras de suas instituições normativas, e de outras práticas, sem-número, que ficaram como 'menores', sempre no entanto presentes, embora não organizadoras de um discurso e conservando as primícias ou os restos de hipóteses (institucionais, científicas), diferentes para esta sociedade ou para outras (CERTEAU. 2013, p. 108)

Essas operações que alteram os lugares e rompem com a organização, provocando movimentos numa ordem estável, são exercidas por "sujeitos praticantes ordinários" do cotidiano, como definido pelo autor (Certeau, 2013). No espaço da escola, pode-se considerar que os praticantes ordinários, "são aqueles que, de modo mais visivel ou mais sutil, deixam suas marcas nesse cotidiano: alunos, professoras, mães, vigias, serventes e tantos outros que 'vivem' as escolas" (FERRAÇO, 2007, p. 74). Sendo assim, a disciplina dentro da escola, bem como suas práticas formalizadas, convive com as ações dos sujeitos cotidianos, que não são passivos diante de tais normalizações e criam seus modos de (r)existir ao que não lhes convém, produzindo diferenças dentro desse ambiente. Logo, a experiência da ação docente no/do cotidiano escolar.

\section{Trânsitos Interdisciplinares em Artes}


possibilita compreender que a escola não se limita ao conceito de um lugar disciplinar. As experiências de seus frequentadores, alunos, professores e funcionários - praticantes ordinários do dia a dia dessas instituições - abrem brechas e criam movimentos, inventando, muitas vezes, outros espaços no lugar instituido.

Frente a isso, para pensar o cotidiano escolar, deve-se levar em conta que apesar de sua estrutura disciplinar e práticas normativas, qualificá-lo apenas por sua ordem disciplinar pode ser um equívoco, uma vez que, em seu território, se entrelaçam práticas formalizadas por um sistema maior e fazeres menores que se exercem pelas ações de seus praticantes cotidianos. Os saberes que pertencem a uma prática institucionalizada, regida por legislações e normativas, obedecem a uma série de organizações prévias, que podem ser pensadas na ordem da estratégia, discutida por Michel de Certeau. "A estratégia postula um lugar suscetivel de ser circunscrito como algo próprio e ser a base de onde se podem gerir as relações com uma exterioridade de alvos ou ameaças"
(Certeau, 2013. p. 93). Outros se inscrevem no cotidiano, pelos praticantes no/do espaço da escola, não possuem sistematização e não estão prescritos, são da ordem tática. A tática "não tem. portanto, a possibilidade de dar a si mesma um projeto global nem de totalizar o adversário num espaço distinto, visivel e objetivável. Ela opera golpe por golpe, lance por lance" (Certeau, 2013, p. 95). Elas, muitas vezes, utilizam-se dos próprios dispositivos disciplinares e recriam a realidade na qual se encontram.

Portanto, ao defendermos uma docência enquanto tática, reconhecemos que um teatro da escola, vai se (des)construindo entre os limites e possibilidades de cada contexto no qual se insere, a fim de fomentar as práticas cotidianas que criam espaços outros. Nesse sentido, ao discutirmos o fazer teatral com crianças pequenas, chamamos a atenção para uma ação docente atravessada pelos diferentes enfrentamentos que se colocam em cada contexto escolar, convocando a (des)construir-se professor(a) de teatro a partir da experiência compartilhada.

\section{Trânsitos Interdisciplinares em Artes}


Por um teatro da escola: desaprendizagens no/do cotidiano de Mangueiras

Dizer que as crianças de Itaúba nos sacudiram é pouco, podemos dizer que provocaram um terremoto. A cada encontro "um nascimento com o outro", como escreve Madalena Freire (2017. p. 154). Contudo, reconhecemos que nascer com o outro não é tarefa fácil, exige idas e vindas, umas coçadas de cabeça e muita paciência, que às vezes falta. Talvez falte porque, mesmo dispostas aos encontros, reconhecemos os engessamentos que carregamos em nossa trajetória. Entretanto, "para apalpar as intimidades do mundo é preciso saber: Que o esplendor da manhã não se abre com faca [...] Desaprender oito horas por dia ensina os principios[...", já dizia o sábio poeta Manoel de Barros (2013, p.275). (Des)aprender para inventar possiveis situações, um teatro da escola.

Como qualquer instituição pública, Mangueiras evidenciava um cotidiano marcado por situações fronteiriças, entre limites e possibilidades. Entretanto, um aspecto a diferenciava e, com o tempo, foi chamando nossa atenção, Mangueiras era um espaço aberto. As presenças de diferentes crianças e Seu José Roberto possibilitaram essa reflexão, demonstrando que, na escola, a porta está aberta para os diferentes saberes, além do saber do professor. Isso fomenta a proposta de docência como ação tática e de processos de trabalho descontínuos, como revela o próprio brincar das crianças.

Pensar a aula como ato performativo possibilitou-nos lidar com as inúmeras imprevisibilidades que surgem no cotidiano das instituições de ensino básico. A experiência junto das crianças revelava aspectos de uma teatralidade que brota de um cotidiano compartilhado, de um brincar criativo que se apropria de um espaço/tempo próprios e não se preocupa em gerar significados. Desse modo, é necessário um olhar que flutue e brinque com esse cotidiano infantil. Assim como as táticas, que estão atentas às situações que surgem.

\section{Trânsitos Interdisciplinares em Artes}

Bárbara Tavares dos Santos, Liliane Scarpin S. Storniolo, Renata Patricia da Silva (Organizadoras) 


\section{Referências}

BARROS, Manoel de. Poesia Completa. São Paulo: LeYa, 2013.

CERTEAU. Michel de. A invenção do cotidiano 1: Artes de fazer. $20^{\mathrm{a}}$ ed. Tradução de Ephrain Ferreira Alves. Petrópolis, RJ: Vozes, 2013

FREIRE, Madalena. Educador, educa a dor. $6^{\mathrm{a} e d}$. Rio de Janeiro: Paz e Terra, 2017.

LARROSA, Jorge. Notas sobre a experiência e o saber de experiência. In Tremores: Escritos sobre experiência. Trad. Cristina Antunes e João Wanderley Geraldi. Belo Horizonte: Autêntica Editora, 2017.

LEHMANN. Hans-Thies. Teatro pós-dramático. Trad. Pedro Sussekind. São Paulo: Cosac Naify, 2007
MACHADO, Marina Marcondes. A criança é performer. Revista Educação \& Realidade, v. 35, n. 2, p. 115-138. maio/ago. 2010

MACHADO, Marina Marcondes. Merleau-Ponty \& a educação. Belo Horizonte: Autêntica Editora, 2010a.

MACHADO, Marina Marcondes. Só Rodapés: Um glossário de trinta termos definidos na espiral de minha poética própria. Revista Rascunhos. Uberlândia, V. 2, n. 1, p. 53-67, jan./jul. 2015

SeCretaria muniCIPAL de eduCAÇÃo. Projeto Político Pedagógico. Augustinópolis - TO, 2017.

\section{Trânsitos Interdisciplinares em Artes}

Bárbara Tavares dos Santos, Liliane Scarpin S. Storniolo, Renata Patricia da Silva (Organizadoras) 


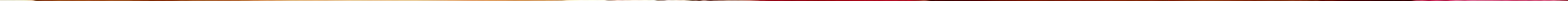




\section{Tessituras de Experiências Cênico-Pedagógicas sobre a Docência da Encenação no Ensino Superior}

Bárbara Tavares dos Santos ${ }^{1}$

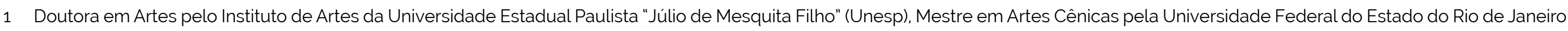

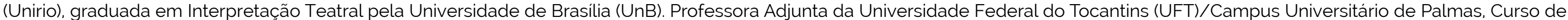
Licenciatura em Teatro. Desenvolve pesquisas no campo do ensino de teatro, encenação, teatralidade, corpo, cinema e televisão, e-mail: barbara.tavaresreis@uft.edu.br.

\section{Trânsitos Interdisciplinares em Artes}

Bárbara Tavares dos Santos, Liliane Scarpin S. Storniolo, Renata Patricia da Silva (Organizadoras) 
Este artigo é de um recorte da tese de doutorado da pesquisadora, intitulada "Poética da encenação: tessituras de experiências cênicas em abordagem feminina sobre a docência da encenação no ensino superior" (2019), orientada pelo professor Alexandre Mate. O objetivo da pesquisa foi o de (re)experiênciar. analisar e discutir, de modo crítico, práticas cênico-pedagógicas, mapear principios, metodologias, expedientes de criação, cotejar e defender os conceitos de poética da encenação e de professoraencenadora ${ }^{2}$.

A fonte deste texto, especificamente, aborda algumas das experiências cênicas da pesquisadora, partilhadas, junto a grupos de estudantes do curso de Licenciatura em Teatro da Universidade Federal do Tocantins (UFT), durante a regência da

2 Professora-encenadora e/ou coordenadora de processos de encenação é a docente mulher, pesquisadora e encenadora que trabalha no âmbito educativo formal ou informal articulando em seu trabalho as dimensões artísticas e pedagógicas. matéria optativa de Direção teatral. Naquele processo, buscouse cotejar diferentes poéticas relativas às linhas da Pedagogia da Encenação desenvolvidas no ensino superior de teatro. Mesmo tendo a consciência de que não se tratava de criar uma proposição epistêmico-metodológica pessoal, a reflexão intentada visou, por meio de todas as experiências analisadas, descortinar e apresentar, de certo modo, estratégias e táticas estéticas fundamentais ao processo de criação cênica, em perspectiva coletiva.

Ao findar da pesquisa, aponto que a prática no campo da docência da encenação - em proposição progressista e libertária - não se sustenta reproduzindo, métodos e/ou modelos preestabelecidos, mas por meio de poéticas cênico-pedagógicas construidas coletivamente, que se configuram como arcabouços de trabalho práticos mutatis mutandis mais abrangentes e sintonizados à realidade histórico-estético-social do contexto em que se opera, portanto mais permeáveis, heterogêneos e flexiveis.

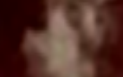 \\ Trânsitos Interdisciplinares em Artes}

Bárbara Tavares dos Santos, Liliane Scarpin S. Storniolo, Renata Patricia da Silva (Organizadoras) 


\section{Pequenos diálogos temporais sobre a arte da encenação com discentes egressos da matéria de Direção Teatral}

Grande parte desta pesquisa deve-se às inquietações e reflexões surgidas durante a regência da matéria de Direção Teatral na UFT, realizadas entre os anos de 2013 e 2017. Foi durante a regência das aulas de Direção que comecei a estudar de forma mais sistematizada os conceitos de direção e encenação. Compreendi com isso, que, embora não se trate de uma definição absolutamente rígida, a noção de direção aparece mais atrelada a um modo de se fazer teatro mais diretivo e verticalizado; já a noção de encenação mantêm relações estreitas com processos de criação colaborativos e horizontais e mais abertos ao trânsito com outras áreas artísticas e afins.

Foi também nesse mesmo contexto de reflexões, que passei a questionar o modo de ensinar encenação, inquietandome questões como: Que professora-encenadora eu me tornara?
Que métodos de encenação poderiamos desenvolver durante as aulas? Que tipo de professores(as)-encenadores(as) eu poderia ajudar a formar? Nesse sentido, a minha intenção primeira não era, (e não é) a de responder de forma absoluta a tais questões. Tendo em vista a complexidade dos assuntos, optei por perpassar por tais questões, buscando redimensioná-las e torná-las "modestas". Até porque os modos de se ensinar encenação estão perenemente transformando-se. Contudo, reconheço que esse processo dinâmico se relaciona às práticas cênicas desenvolvidas ao logo da carreira docente, e, por conseguinte, estão "emaranhados" às minhas práxis de professora-encenadora.

Sendo assim, pretendo neste tópico explorar e analisar. alguns possiveis entendimentos sobre a arte da encenação, sobre o ofício da professora-encenadora e sobre as relações de criação junto aos estudantes de teatro, contidas em relatos de experiências cênico-pedagógicas vivenciadas por discentes, da matéria de Direção Teatral, hoje já egressos do curso de Teatro da UFT.

\section{1 (1) \\ Trânsitos Interdisciplinares em Artes}

Bárbara Tavares dos Santos, Liliane Scarpin S. Storniolo, Renata Patricia da Silva (Organizadoras) 
Pretendo, assim, estabelecer diálogos temporais entre o pensamento dos discentes e o meu, a fim de encontrar possiveis apontamentos para as questões que deixei abertas até então. Esclareço que os relatos de experiências transcritos fazem parte dos itens de avaliação que foram aplicados durante as matérias que estiveram sob minha regência, e que os nomes dos estudantes participantes dos cursos foram trocados por pseudônimos fictícios para que fossem preservadas suas identidades. Esclareço ainda que, embora todos(as) estudantes utilizem em seus relatos os termos direção e diretor(a), no que concerne à minha análise optei por utilizar os termos encenação e encenador(a).

A seguir os relatos dos participantes e as respectivas análises que os acompanham.

\section{Relato [1]}

Antes de começar a descrever como foram os meus processos de criação e montagem de cenas, quero antes fazer um breve comentário como foi minha experiência com a disciplina de Direção Teatral. A princípio, eu tinha em mente que seria algo mais teorizado, estudos voltados para a construção da cena de maneira analítica, por assim dizer o entendimento da cena no que concerne a sua análise estética. Todavia, fui pego de surpresa, pois toda a disciplina é de cunho prático, é a direção teatral no aprender fazendo, o que eu particularmente gostei, por ser um processo dinâmico e prático e ao mesmo tempo não perder em seu conteúdo teórico, já que os referenciais de criação de cenas de teatro são a todo tempo mencionados nos improvisos e práticas cênicas que vivenciamos. Outro ponto bastante relevante é o fato de nós estudantes sermos os diretores nos exercícios de cena, a criação se torna mais aberta às perspectivas e estilo teatrais que cada estudante é mais familiarizado (Relato de experiência. Matéria de Direção Teatral, Romeu, 2014).

Ao elaborar a ementa da matéria de Direção Teatral, meu principal objetivo era o de conseguir trabalhar de forma concomitante a teoria e a prática cênica. Além disso, julguei ser importante para

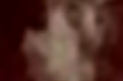 \\ Trânsitos Interdisciplinares em Artes}

Bárbara Tavares dos Santos, Liliane Scarpin S. Storniolo, Renata Patricia da Silva (Organizadoras) 
os estudantes exercitarem o olhar sobre a encenação a partir de diferentes matrizes criadoras. Sabendo, então, que teriamos um total de oito encontros de trabalho, elaborei as atividades pedagógicas de forma que, no primeiro dia de aula, discutíssemos, panoramicamente, algumas concepções de direção/encenação teatral do início e do final do século XX, sobretudo, aquelas ligadas às obras e às práticas cênicas de significativos encenadores(as)pedagogos(as) da Europa central e do Brasil. A partir da segunda aula, passariamos às atividades práticas, dividindo a turma em dois grupos, que se revezavam nas funções de intérpretes e encenadores(as).

Assim, na segunda aula, realizávamos, coletivamente, um conjunto de improvisos cênicos nos quais eu apontava algumas questões pertinentes ao trabalho e ao olhar do encenador(a), tais como: observar nas cenas o jogo com metáforas, metonímias e ressignificações; observar as mensagens subliminares, contidas nos textos, ações e falas das personagens; experimentar nos improvisos o uso de recursos e técnicas teatrais como o sistema de coringamento, o uso do coro e de efeitos épicos de distanciamento/ estranhamento 3 .

Discutíamos também sobre as intensidades das cenas (forte, fraca), sobre o ritmo das ações, gestos e movimentos corporais realizados pelos sujeitos da cena (lento, normal e rápido) e sobre os usos dos planos cênicos espaciais (baixo, médio e alto), assim como usos de espaços alternativos para a realização das encenações. Experimentávamos ainda, diferentes opções de entradas, saídas e posicionamentos dos atuantes no palco. Por fim. trabalhávamos com experimentações de figurinos e de iluminação a fim de observarmos relações entre cores e texturas e seus efeitos cênicos no todo da encenação.

3 O sistema coringa ou coringamento é uma forma de montagem cênica na qual as atrizes e os atores do elenco revezam entre si as personagens de uma peça. No Brasil, a técnica. proposta - com esse nome - por Augusto Boal está entrelaçada com a história do Grupo Teatro Arena, fundado em 1953, por José Renato Pécora. Segundo Bertolt Brecht, e em tese, o distanciamento pressupõe, antes de tudo, apontar, destacar, sublinhar de um fato ou comportamento o que neles possa haver de "natural", conhecido, indiscutivel, e, fazer nascer em seu lugar o espanto, a curiosidade, a inquietação.

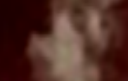 \\ Trânsitos Interdisciplinares em Artes}

Bárbara Tavares dos Santos, Liliane Scarpin S. Storniolo, Renata Patricia da Silva (Organizadoras)

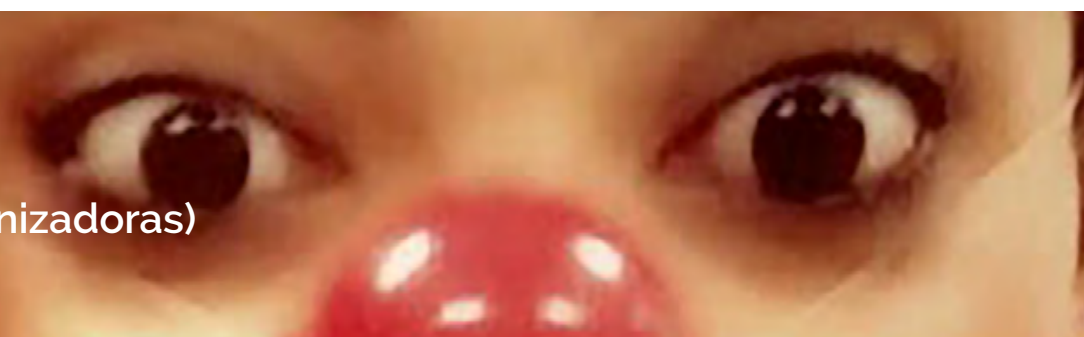


As seis aulas subsequentes foram destinadas exclusivamente para os trabalhos de criação/encenação individuais ou em dupla. Os estudantes apresentavam duas propostas de cenas curtas, de no máximo, dez minutos cada. Uma das cenas era composta a partir da perspectiva textocêntrica (necessariamente ligada à literatura); a outra, cenocêntrica relacionada ao fazer da cena em si mesma, ligada a matrizes geradoras mais abertas como música, imagens, dança, performance, cinema, literatura entre outras.

Em função do conteúdo a ser estudado ser muito extenso e a carga horária de 32 (trinta e duas) horas ser insuficiente para o efetivo ensino e aprendizagem da encenação, acordamos, coletivamente, desde o primeiro dia de aula, que os estudantes realizariam ensaios extraclasse com os seus respectivos núcleos de atrizes, atores e demais criadores das cenas. Em função desse curto tempo, os estudantes apresentaram via AVA (Ambiente Virtual de Aprendizagem) dois pré-projetos escritos de encenação. Eu lia e avaliava cada projeto antes da terceira aula. A partir das escolhas cênicas que haviam sido feitas pelos estudantes, eu direcionava alguns estudos teóricos e/ou sugeria a investigação de prática e técnica de atuação mais específica.

Nesse momento do curso, os improvisos e os ensaios de cenas já estavam sob a regência dos estudantes, que se colocavam na função de encenadores(as). Durante esses ensaios abertos, eu problematizava os processos de criação e as cenas desenvolvidas e mostradas durante as aulas, e, conforme o andamento das criações coletivas e/ou dos interesses pessoais de cada estudanteencenador(a), eu sugeria soluções e/ou referências de estudos que pudessem contribuir com o trabalho final de encenação.

Assim, nas quatro aulas/ensaios abertos, trabalhávamos concomitantemente, e de forma coletiva, a práxis do fazer teatral e da encenação, deixando as duas últimas aulas para as apresentações públicas dos resultados cênicos alcançados.

Os objetivos pedagógicos com essa metodologia de trabalho visavam: primeiro, aperfeiçoar e aproveitar ao máximo o curto tempo de que dispúnhamos em sala de aula; depois, conseguir. ao longo do processo de criação, apresentar, discutir e experimentar

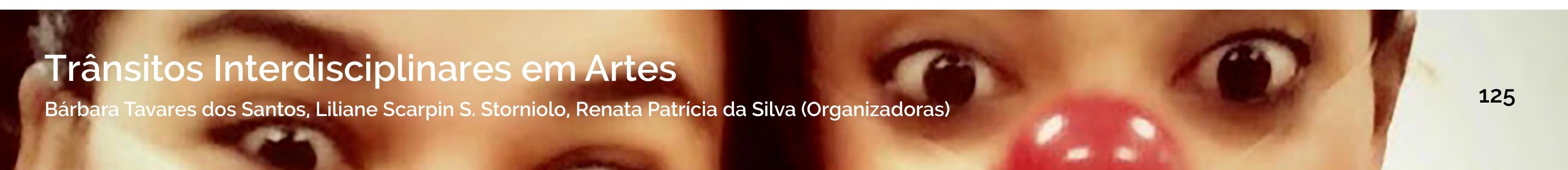


coletivamente, de forma prática, um conjunto de elementos técnicos e de recursos cênicos que possibilitassem aos estudantes adquirirem um repertório mínimo de trabalho como encenadores(as).

Conduzi as aulas dessa forma, por entender que, a partir do domínio de um conjunto de expedientes e procedimentos práticos e básicos de encenação, os estudantes teriam mais autonomia em seus processos de trabalho desenvolvidos com os seus núcleos de criadores cênicos. E, assim, estariam mais aptos a compor e apresentar as cenas finais conforme suas intenções estéticas, seus planejamentos de trabalho individuais e coletivos e seus desejos pessoais de criação.

Ressalto, todavia, que o processo de trabalho desses conteúdos chega a ser quase um contrassenso, uma vez que tínhamos apenas oito encontros, durante todo o semestre, para efetivamente ensinarmos encenação para turmas que tinham em média 20 estudantes matriculados. Em sintese, o estudo da encenação, que abarca atividades práticas e teóricas, poderia ser mais produtivo e aprofundado se a matéria não fosse optativa, e se não tivesse uma carga horária tão reduzida. Em função disso, muitos elementos da encenação eram estudados de forma bastante panorâmica, e isso afetava principalmente os processos de mediação e condução do trabalho técnico, realizado pelo estudante-encenador(a) junto às atrizes e atores.

Nessa realidade de trabalho pedagógico de que dispomos, considero excepcionais os resultados cênicos alcançados. Além disso, ressalto também que tais resultados só ocorreram satisfatoriamente, do ponto de vista estético-pedagógico, porque os estudantes cursam a disciplina de Direção teatral no $7^{\circ}$ período letivo, quando já compreendem e manejam um escopo maior de técnicas e de conhecimentos teatrais. Caso contrário, seria inviável realizar esse trabalho de forma produtiva.

De todo modo, a fala do estudante Romeu, embora seja uma voz num coro maior de discentes, não deixa de ser também um indicativo de que, parte dos intentos pedagógicos na época da regência dessa matéria, foi alcançado por meio da proposição metodológica empregada.

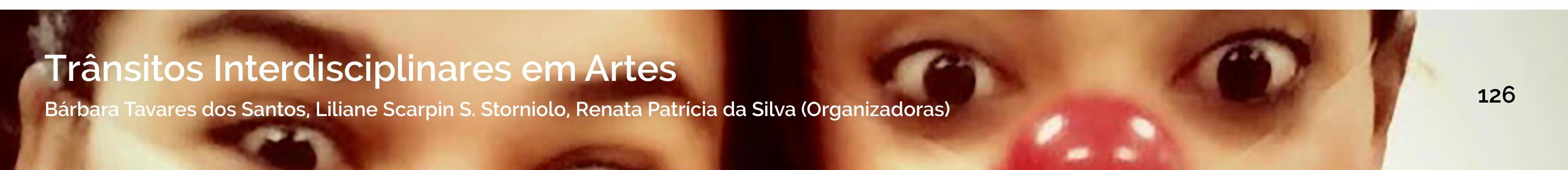




\section{Relato [2]}

O texto que escolhi para trabalhar na cena fechada foi "Eles não usam Black-tie", de Gianfrancesco Guarnieri. Inicialmente tinha decidido fazer a cena em que acontece o diálogo de Romana com Maria, onde a personagem Maria revela a sua gravidez para a senhora Romana, sua sogra e confidente. No entanto, no ensaio aberto para turma a professora Bárbara argumentou que talvez essa não fosse a melhor cena a ser feita em um experimento cênico de cinco a dez minutos, pois esse trecho não alcançava exatamente o contexto maior da peça, já que o tema chave da trama não era a gravidez de Maria, e sim a escolha da personagem Tião em furar a greve. gerando, assim, o grande conflito da obra. Por isso, resolvi aceitar a sugestão da professora e voltei a trabalhar no texto. Li a peça novamente e decidi fazer uma adaptação da obra, mas, ainda assim utilizando das mesmas personagens (Romana e Maria). Um dos meus motivos foi o de aproveitar o material de trabalho humano que já tinha disponivel. Além disso, gosto muito das duas personagens, principalmente da Romana. Queria trazer para adaptação um olhar feminino diante dos conflitos da greve e da discussão sobre a frágil condição humana que está presente na peça. Para facilitar o processo, devido ao pouquíssimo tempo que tínhamos na disciplina de Direção, apostei em uma cena pequena dividida em três partes: A primeira seria Romana lavando roupas. Nessa primeira parte, eu pedi às atrizes que trouxessem os principais conflitos da peça, onde Romana fala do noivado de Tião, da greve, da perda da filha, da preocupação com o marido e com os filhos. Na segunda parte, o foco estaria com a personagem Maria, onde ela refletiria sobre a sua relação com o Tião, revelando sua gravidez e demonstrando preocupação com o noivo. Na terceira e última parte. propositalmente quis trazer novamente Romana para cena, só que agora de modo mais cômico, mais leve, dando assim um desfecho para encenação (Relato de experiência. Matéria de Direção Teatral, Electra, 2014, in memoriam).

Ao reler o relatório da estudante Electra, me vêm à tona alguns questionamentos. Qual deve ser o papel da docente na condução de outros professores encenadores? De que modo efetivamente posso contribuir com a formação dos estudantes

\section{Trânsitos Interdisciplinares em Artes}

Bárbara Tavares dos Santos, Liliane Scarpin S. Storniolo, Renata Patricia da Silva (Organizadoras)

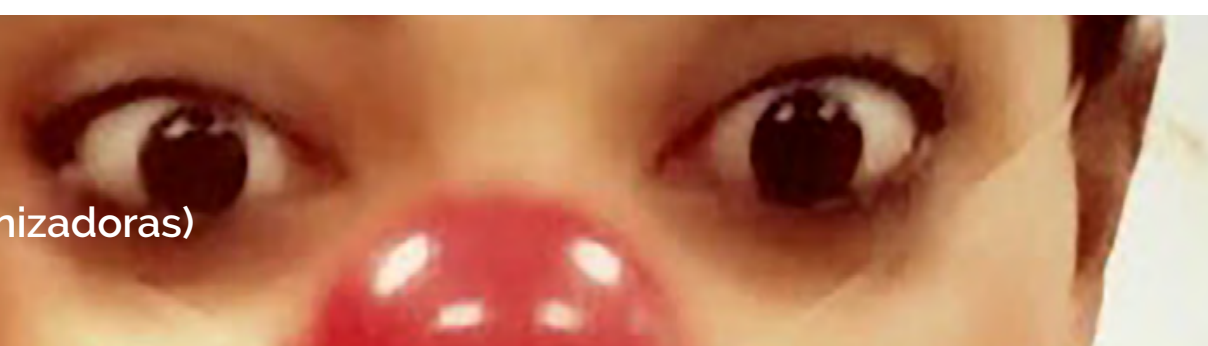


no campo da encenação, sem necessariamente impor a minha visão do teatro, mas, também ao mesmo tempo, apontando o que percebo de fragilidade nas cenas que eles(as) desenvolvem e apresentam na função de encenadores(as)?

No sentido de compreender tais questões, noto que minha intenção, ao provocar a estudante Electra, foi a de estimulála a reler a obra que ela havia escolhido encenar, de forma que ela em conjunto com as demais criadoras, compreendessem em profundidade os sentidos do texto dramático e pudessem, assim, confrontá-los com seus intentos estéticos de encenação.

Isso, nada mais é do que ler verticalmente a obra teatral, procurando compreender as suas nuances e contradições, buscando os significados e significantes estéticos, históricos e socioculturais da obra literária a ser encenada. Ou seja, Electra precisava perceber o que (ela), enquanto discente, que se colocava na condição de encenadora, poderia potencializar, discutir, ou mesmo, contrapor no trabalho da atuação e no jogo com os demais elementos plásticovisuais e sonoros da encenação.
Nesse sentido, penso que a provocação tenha sido produtiva, uma vez que a estudante Electra, que era a coordenadora do processo da encenação, não só releu a obra teatral, como também readaptou o texto e extraiu dele um novo sentido estético e político, para compor a cena, conjuntamente com as atrizes, mantendo, ainda, as mesmas proposições feministas que Electra haviam intencionado apresentar desde o início do processo de criação. Em sintese, ela desenvolveu uma autonomia individual e um domínio sob os meios de criação e produção técnico-teatrais e, ao mesmo tempo, propiciou também que fosse impressa à encenação às "autoralidades" das duas atrizes participantes envolvidas no processo da criação cênica.

\section{Relato [3]}

Na apresentação da cena fechada, tentei trazer para as atrizes perguntas para que elas pudessem me dar um retorno. Como você pensa a cena? O que você achou da proposta apresentada pela direção? Tentei ao máximo não fazer com que o roteiro mental que eu tinha de cenas

\section{. \\ Trânsitos Interdisciplinares em Artes}

Bárbara Tavares dos Santos, Liliane Scarpin S. Storniolo, Renata Patricia da Silva (Organizadoras) 
pudesse influenciar absolutamente na atuação delas. Mas, sim, conciliar o que eu tinha em mente como o que as atrizes podiam criar a partir do roteiro de ações que eu havia apresentado. Em nenhum momento quis demonstrar a imagem da diretora como a centralizadora do processo de criação, porque de fato não acredito que a direção consiga trabalhar desse modo (Relato de experiência. Matéria de Direção Teatral, Medéia, 2016).

\section{Relato [4]}

O que ficou para mim da experiência de dirigir é que é preciso deixar o ator criar também, nessa disciplina eu tive a oportunidade de atuar em todas as outras cenas dos meus colegas de turma, e cheguei à conclusão de que o diretor precisa descobrir junto com os atores o desenrolar da cena que está em processo e, principalmente, precisa descobrir quais os pontos fortes dos atores e usar isso a favor deles (Relato de experiência. Matéria de Direção Teatral, estudante Desdêmona, 2015)
Na mediação da disciplina de Direção Teatral, procuro estimular o empoderamento dos sujeitos estudantes que se colocam como encenadores(as), de modo que eles(as) compreendam que essa função está atrelada ao papel da liderança e da coordenação cênica. Contudo, enfatizo sempre que a prática da encenação não se efetiva por meio de posturas centralizadoras e autoritárias. Isso pode ser constatado na fala da estudante Medéia.

Nesse sentido, afirmo que o trabalho de encenadores(as) só se perfaz no perene diálogo com os demais criadores(as) cênicos, sobretudo com atrizes e atores. E, é por isso que, a estudante Desdêmona afirma que chegou à conclusão de que "o diretor(a) precisa descobrir junto aos atores o desenrolar da cena que está em processo e, principalmente, precisa descobrir quais os pontos fortes dos atores e usar isso a seu favor".

Esse cuidado de abrir o canal de escuta para os(as) artistasestudantes envolvidos na encenação é uma prática permanente em minhas aulas, tanto que isso pode ser percebido no eco dos relatos,

\section{Trânsitos Interdisciplinares em Artes}

Bárbara Tavares dos Santos, Liliane Scarpin S. Storniolo, Renata Patricia da Silva (Organizadoras)

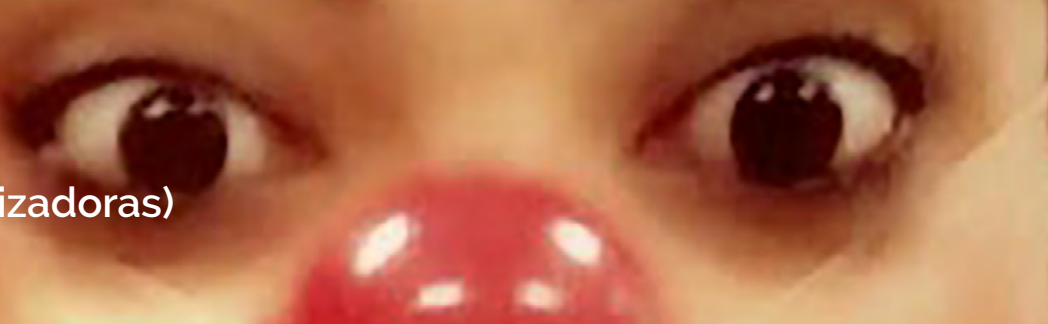


anteriores, das duas estudantes que participaram da disciplina. As discentes internalizaram que cabe aos que se colocam no papel de encenadores(as) o olhar externo de coordenar o todo da obra que está sendo criada. No entanto, a cena, quando de seu acontecimento ao vivo, é a arte de atrizes e atores, pois são eles os atuantes que guiam a aventura narrativa e audiovisual diante do público. É por isso que o trabalho de encenadores(as) deve ocorrer, fundamentalmente. em processo e em diálogo com as atrizes e atores.

Então, quando os estudantes me perguntam: Qual seria o nosso papel na função de professores-encenadores(as)? Respondo que somos provocadoras e espectadoras natas. Somos a primeira e perene audiência da cena, somos as artistas que olham as ações do/no palco e imaginam possibilidades de cores, sons, figurinos, luzes e ações acerca das histórias que estão sendo contadas.

Por exemplo, em um dado momento de improvisos cênicos livres, olhamos no tablado para um grupo de atrizes improvisando e ouvimos os sons das risadas e das batidas que os pés delas provocam ao dançar e correr pelo palco. De repente. perguntamos ao grupo: O que são essas ações e esses sons que vocês estão criando? O que isso lembra? Ao escutar das atrizes a resposta: "Esses sons lembram as brincadeiras da infância", a encenadora talvez possa dizer: "Perfeito! Sigam por esse caminho de criação e mantenham a atenção psicofísica. Ouçam com os pés, com os olhos, com a espinha, com a cabeça, com todo o corpo. 0 som é seu parceiro de jogo. Dê a ele o seu lugar no espaço, porque daí nós, espectadores, também veremos e ouviremos com vocês os sons e as imagens de suas infâncias".

E, assim, desse modo, por meio de diálogos, vamos criando e tecendo em parceria com as atrizes e atores a grande teia de afetos, sentidos e signos teatrais que vão se constituindo nas poéticas da encenação.

\section{Relato [5]}

Escolhi a obra a ser montada e comecei então a pensar na cena e na atriz que faria "a minha Ofélia". Convidei minha amiga Aline, por sua disponibilidade e sua entrega em cena. Marquei três ensaios divididos em: 1) Conhecendo o texto;

\section{Trânsitos Interdisciplinares em Artes}

Bárbara Tavares dos Santos, Liliane Scarpin S. Storniolo, Renata Patricia da Silva (Organizadoras) 
2) Construindo uma partitura; 3) Acabamento da Cena [...]. Sobre a apresentação final desta cena, apesar do tempo de ensaio ter sido muito curto, conseguimos realizar tudo o que foi planejado. Gostaria de trabalhar e aprimorar esta cena mais e mais. Dirigir, mesmo que como um breve exercício acadêmico, nos faz chegar a outro lugar. Não é somente estudar uma obra ou praticar técnicas teatrais. Direção é um exercício complexo que exige generosidade e uma visão de conjunto. Digo isso porque tudo o que eu apreendi durante o meu processo formativo até agora, de certa forma, foi determinante para a realização das duas cenas que tive que montar na matéria de Direção Teatral (Relato de experiência. Matéria de Direção Teatral, Julieta. 2015).

O Relato [5] demonstra que, durante os experimentos cênicos, quando nos colocamos na função de encenadoras(es), vamos desenvolvendo metodologias e os procedimentos de criação coletivos. Ou seja, vamos construindo, colaborativamente, poéticas de encenação muito singulares, adaptáveis a cada coletivo e a cada contexto de trabalho. Por exemplo, a estudante Julieta, diante do pouquíssimo tempo de ensaio para compor e apresentar uma cena na disciplina de Direção Teatral, sistematizou o seu próprio caminho de trabalho para que pudesse, assim, conduzir a atriz no processo da criação.

Não se trata de uma metodologia inédita, pelo contrário, Julieta simplesmente reelaborou uma pequena sintese de estudos e metodologias já existentes no teatro. Como a exemplo, a proposição de Viola Spolin, conforme citação a seguir:

O jogo teatral são técnicas do diretor. Cada jogo, quase sem exceção, foi desenvolvido com o propósito de fazer com que alguma coisa aconteça no palco. Eles solucionam problemas com marcação, personagens, emoção, tempo e as relações dos atores com a plateia. Cada jogo teatral é uma varinha de condão e, como tal, desperta o intuitivo, produzindo uma transformação não apenas no ator/ jogador como também no diretor/instrutor (SPOLIN, 2001. p. 18-19).

\section{Trânsitos Interdisciplinares em Artes}

Bárbara Tavares dos Santos, Liliane Scarpin S. Storniolo, Renata Patricia da Silva (Organizadoras)

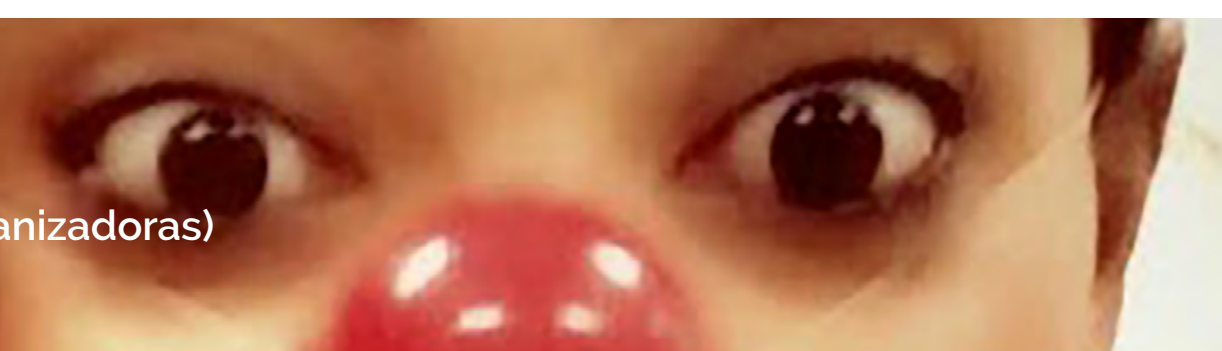


Segundo Julieta descreveu em seu relato, o primeiro passo da criação foi conhecer o texto teatral; depois, desenvolver partituras; e, por fim, realizar os acabamentos e as marcações de cenas. Um caminho de encenação em três etapas, disposto de forma simples, objetiva, prática e eficiente para um trabalho cênico com pouquíssimo tempo para ser realizado.

Na proposição de trabalho de Julieta, percebo uma ressonância, com a ideia defendida da pesquisa, de que não existe um método específico para encenar, consequentemente, para ensinar encenação, pois a encenação se caracteriza não propriamente em uma metodologia, mas em uma poética que se efetiva e que se concretiza a partir dos encontro e das trocas de experiências cênicas, partilhadas em contextos muito específicos de criação e trabalho coletivo.

Julieta e a atriz que trabalhou junto a ela no processo da criação, apresentaram no resultado final da disciplina de Direção teatral, um pequeno trecho da personagem Ofélia, da obra Hamlet de Shakespeare. Guardo comigo a reminiscência de uma cena forte, feminista, bela e plástica. A primeira imagem que víamos em cena era da personagem Ofélia de costas, vestida de noiva no centro do palco. Ao virar-se para o público, segurando um buquê de flores, a personagem nos olhava diretamente nos olhos como se pedisse a nossa ajuda para não se afogar em um mar de tristezas, desgostos e desilusões. A calda de seu vestido de renda branco era tão grande que circundava uma boa parte do palco. Ao contar a história de Hamlet, Ofélia narrava também as dores de sermos mulheres, de sermos mães e filhas em um mundo patriarcal. Ela falava das dores de tantas meninas que amaram de forma inocente. demasiada e incondicional, e, que, paradoxalmente, tiveram suas vidas ceifadas pelo amor.

Essa cena, embora não seja estruturada no modelo épico brechtiano, foi concebida em uma proposição cênica na qual a atriz rompia com a "Quarta parede"4 e trazia a audiência para o

4 A Quarta Parede é uma parede imaginária situada na frente do palco do teatro, através da qual a plateia assiste passiva à ação do mundo encenado.

\section{Trânsitos Interdisciplinares em Artes}

Bárbara Tavares dos Santos, Liliane Scarpin S. Storniolo, Renata Patricia da Silva (Organizadoras)

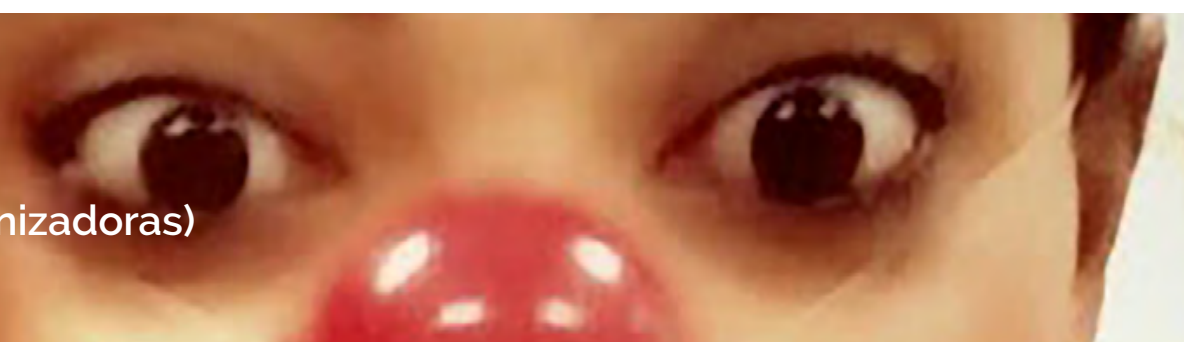


palco colocando-nos como coparticipantes, de certo modo, como cúmplices do drama que vinha à tona do desenrolar das ações. Assim, à medida que Ofélia narrava a sua história, paulatinamente, ela transformava e ressignificava a calda de seu vestido de noiva. Primeiro a calda parecia virar um capote de toureiro, depois uma cama, uma forca, até que, finalmente, transformava-se em um mar de água, de terra e de lama no qual Ofélia, sozinha e desesperada, sucumbia afogada diante de nossa incapacidade de ajudá-la. Uma cena de proposição cênica crítico-feminista que, pela beleza e força das ações executadas pela atriz no palco, foi ao mesmo tempo poética e política.

O relato de Julieta também aponta uma ressonância de sua voz, com a hipótese que é levantada na pesquisa sobre o entendimento do fenômeno teatral, em suas articulações e complexidades estéticas, históricas e políticas ser compreendido em maior profundidade, quando exercitamos a prática da encenação colocando-nos na função de encenadoras(es). Afirmo isso, não por entender que a função de encenador(a) seja superior às outras funções na criação da cena, mas, sobretudo, porque ela requer que se tenha uma visão ampla do fenômeno teatral.

Assim, quando os encenadores(as) reúnem-se com os seus coletivos de trabalho eles(as) não estão ali porque sabem tudo, ou mesmo para fornecer todas as respostas e soluções cênicas, mas para estimular a pesquisa, a reflexão coletiva, a dúvida, a permanente inquietação e o questionamento em face à obra e a vida. Portanto, essa função requer uma visão de conjunto e um perene diálogo com os criadores(as) cênicos e também com outros campos do saber ligados à filosofia, a política e outras tantas Artes. Provavelmente é em virtude disso, que a estudante Julieta afirma que: "Dirigir, mesmo que como um breve exercício acadêmico, nos faz chegar num outro lugar. Não é somente estudar uma obra ou praticar técnicas teatrais. Direção é um exercício complexo que exige generosidade e uma visão de conjunto".

\section{Trânsitos Interdisciplinares em Artes}

Bárbara Tavares dos Santos, Liliane Scarpin S. Storniolo, Renata Patricia da Silva (Organizadoras)

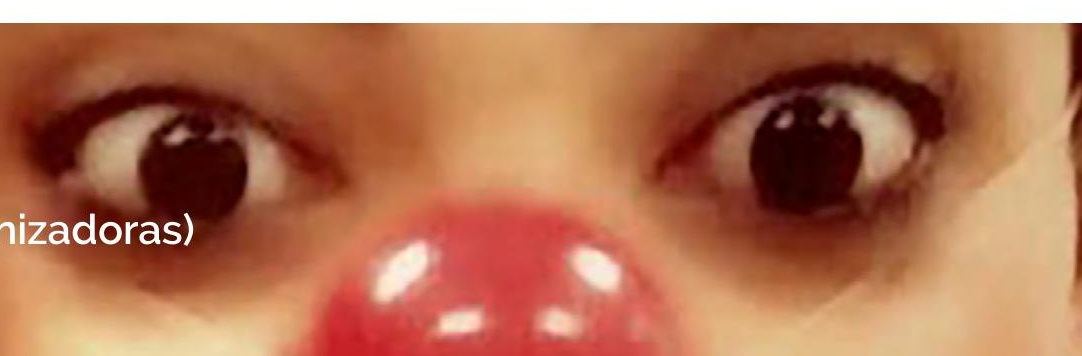


Ressalto também, que mesmo quando a estudante Julieta afirma estar procurando a atriz que possa representar a Ofélia que idealiza, ela faz a referência no texto, colocando aspas na expressão, porque sabe que tudo aquilo que efetivamente é mostrado em uma cena é construido em parceria. Por isso Julieta afirma ter convidado atriz e amiga de graduação. Aline, pela sua disponibilidade e entrega para realizar conjuntamente a cena. Porque, acima de tudo, a relação entre encenadores(as) atores e atrizes, precisa ser de amizade, de entrega e de confiança mútua.

\section{Relato [6]}

Ensaio 2 - No segundo ensaio nós mantemos o aquecimento corporal, trabalhamos com os atores a partir do estudo do movimento de Laban, trabalhamos com a alternância de momentos fortes e o leves, incluindo ações como flutuar, empurrar, espanar. Deixamos que eles criassem movimentos a partir dessas improvisações. Nesse dia estavam um pouco dispersos, no meio do ensaio tivemos que aplicar um jogo de contato e improvisação em que nós as diretoras, fazíamos o exercício individual com eles, até chegar o momento em que eles se encontravam e começavam entre eles os movimentos, acredito que fluiu um pouco (Relato de experiência. Matéria de Direção Teatral, Margarida, 2015).

Nosso trabalho como encenadora é um perene exercicio de apresentar proposições cênicas, de fazer observações e análises sobre a atuação e sobre o conjunto dos demais elementos mostrados em cena. Estamos, portanto, a todo tempo refletindo acerca das alternativas, soluções, mudanças e acabamentos dos materiais cênicos.

Em função disso, conforme Margarida aponta, algumas vezes precisamos intervir na cena para conduzir as atrizes e atores não apenas com palavras e olhares, mas também como o nosso próprio corpo. Sim, o nosso próprio corpo. Nós encenadoras(es) deixamos rastros de nossos corpos nos espetáculos que encenamos, coletivamente, conforme relato do artigo, "Rastro

\section{Trânsitos Interdisciplinares em Artes}

Bárbara Tavares dos Santos, Liliane Scarpin S. Storniolo, Renata Patricia da Silva (Organizadoras) 
como presença de uma ausência: sete movimentos dos corpos de encenadore(a)s", escrito pela pesquisadora em parceria com o professor-encenador Francis Wilker.

No desenvolvimento de um processo de criação cênica, o trabalho de encenadoras(es), que colocam à disposição seus corpos ao ato criativo é movido constantemente por fluxos de intencionalidades signicas, tecendo, forjando, compondo com os corpos de atrizes e de atores, esses, sim. os seres sempre vistos em cena. Nessa feitura, nós encenadoras(es) lidamos com as dimensões invisiveis da memória, da intuição, do acaso, do acidental e daquilo que nos escapa e que involuntariamente torna-se rastro. marca, vestígio, cicatriz. Nesses exercícios, nossos corpos se colocam na sala de ensaios, muitas vezes fisicamente. experimentando, potencializando, investigando, a partir da ação poética, e redimensionando com os atuantes o tempo e o espaço da encenação. Isso porque a encenação é um ato relacional e nossas ações de encenadoras(es) interferem e afetam os corpos dos demais criadores, bem como nossos corpos também são simultaneamente afetados pelo agir dos demais envolvidos no processo da criação (SANTOS; CARVALHO, 2019, p. 67-68).

\section{Relato [7]}

Na proposta de cena fechada escolhemos como matriz de criação o texto da mitologia grega A caixa de Pandora. Sentei com meu colega para pensarmos na construção da cena, analisamos vários momentos da fábula e optamos por trabalhar com a parte em que pandora desse do templo Olimpo até o momento em que ela abre a caixa libertando os "males" no mundo. Foi muito difícil trabalhar a direção desta cena em dupla, pois eu e meu colega de turma tínhamos opiniões muito diferentes. Houve momentos na cena em que eu queria a atriz com o olhar fixo em algo, enquanto o colega de direção queria que ela olhasse para várias direções. Então experimentamos os dois modos de olhar e os gestos que eu havia sugerido e depois os que ele havia sugerido para que pudéssemos escolher o melhor resultado. Quanto às características da personagem desta cena, o colega entendia que tinha que ser uma mulher imponente com um pequeno toque de sedução, já

\section{Trânsitos Interdisciplinares em Artes}

Bárbara Tavares dos Santos, Liliane Scarpin S. Storniolo, Renata Patricia da Silva (Organizadoras)

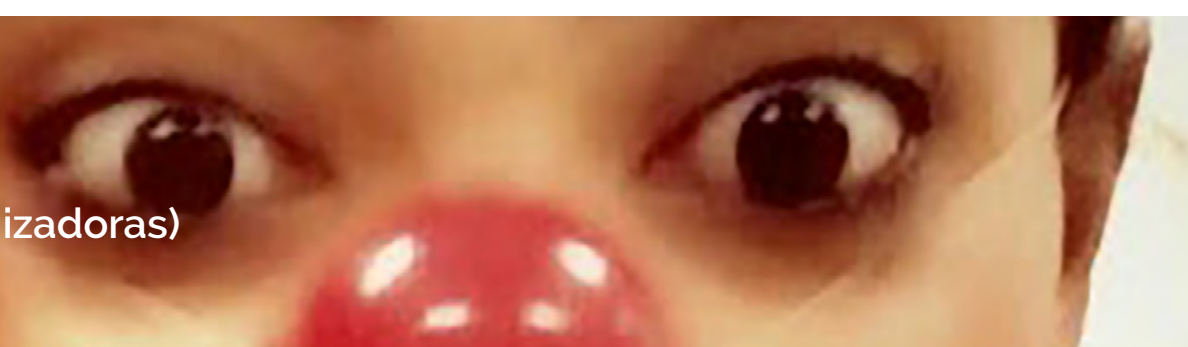


eu queria uma mulher forte mais com o olhar ingênuo. Para que a cena tivesse andamento, optamos por ouvir a atriz e mesclar as ideias que nós três tínhamos da cena (Relato de experiência. Matéria de Direção Teatral, Yago, 2014)

\section{Relato [8]}

O que resulta do encontro entre ator e diretor não é a expressão individual de um ou de outro, mas uma terceira visão que contém em si caminhos percorridos durante as investigações, experimentações e vivências (Relato de experiência. Disciplina de Direção Teatral, Hamlet. 2015).

Nas falas dos estudantes Yago e Hamlet, de certo modo, penso que esteja também contido a ideia, apontada ao longo da pesquisa, de que a poética da encenação é a resultante das trocas de saberes, das deambulações e dos entrecruzamentos de experiências que são partilhadas nos processos criativos. Segundo Hamlet, "[...] o resultado do encontro entre atriz, ator encenador(a) não é a expressão individual de um ou de outro, mas uma terceira visão que emerge", ou seja, um elemento cênico hibrido.
É por isso também que, de outro modo, Yago pontua que é mais complexo dirigir em dupla, pois, quando a encenação se perfaz coordenada por duas cabeças se instala no processo criativo uma intricada diade de condução dos criadores cênicos. Em função da parceria de criação em dupla, estamos, ainda mais, entrecruzando ideias, metodologia, interpretações, soluções e desejos. Na encenação conduzida em dupla, há uma circulação maior das informações, mas há também momentos de embates, de discordâncias e de ter que lidar com as frustrações pessoais.

Vivenciei alguns experimentos cênico-pedagógicos realizados em dupla. Desses que sempre foram muito fecundos e produtivos. Apreendi que duas cabeças pensam melhor que uma, mas que é realmente preciso que elas pensem em conjunto para alcançar o resultado cênico almejado. Além disso, é importante também dividir as funções para o fluir do processo criativo. Entendi que podemos e devemos apostar nas diferenças de competências e habilidades, e que os conflitos são bem-vindos no processo da criação coletiva em Arte.

\section{Trânsitos Interdisciplinares em Artes}

Bárbara Tavares dos Santos, Liliane Scarpin S. Storniolo, Renata Patricia da Silva (Organizadoras) 
Em suma, ao longo de seis semestres, regendo a disciplina de Direção Teatral, fui notando que, essa função de mediadora das encenações conduzidas pelos discentes, caracteriza-se em uma posição de desapego, posição esta em que consigo secundarizar minhas próprias criações cênicas. Consigo manter o distanciamento e a calma que são produtivos para olhar, analisar e problematizar as contradições das cenas, as atuações, os usos de espaços, de iluminação, de cenografia, maquiagens e de releituras de textos, quando esses se fazem presentes na encenação.

Percebi que essa matéria confere à professora-encenadora uma atuação de ser muito mais provocadora do que condutora de tarefas como ocorre, por exemplo, na disciplina de Montagem Teatral. Descobri o quanto aprecio olhar para o trabalho de encenação dos estudantes e o quanto consigo vibrar com o resultado que eles(as) conseguem atingir em tão pouco tempo de experimentos em sala de aula.

Em termos metodológicos, percebi que estruturo a matéria apontando um conjunto mínimo de procedimentos e expedientes de criação teatral, de modo a que os estudantes sintam-se livres para experimentar as suas escolhas cênicas, mas, ao mesmo tempo, eu forneço alguns princípios teatrais e técnicas básicas de construção de cenas, e os coloco também em situações limites, nas quais possam descobrir, em conjunto com os coletivos de criação, as respostas e soluções para as questões de encenação relacionadas com a ética, a estética, a história, a política, ou mesmo questões de cunho interpessoal, que se façam presentes nos procedimentos e expedientes criativos.

Nesse sentido, o trabalho docente é conduzido de forma muito mais no intuito de levantar possibilidades e poéticas de encenação do que propriamente definindo ou elegendo determinados referenciais e/ou modelos teatrais a serem rigorosamente seguidos pelos estudantes. Tenho com isso buscado trabalhar a partir de uma pluralidade metodológica e interessa-me ver as diferentes poéticas cênicas desenvolvidas e apresentadas nas aulas de Direção Teatral.

\section{Trânsitos Interdisciplinares em Artes}

Bárbara Tavares dos Santos, Liliane Scarpin S. Storniolo, Renata Patricia da Silva (Organizadoras)

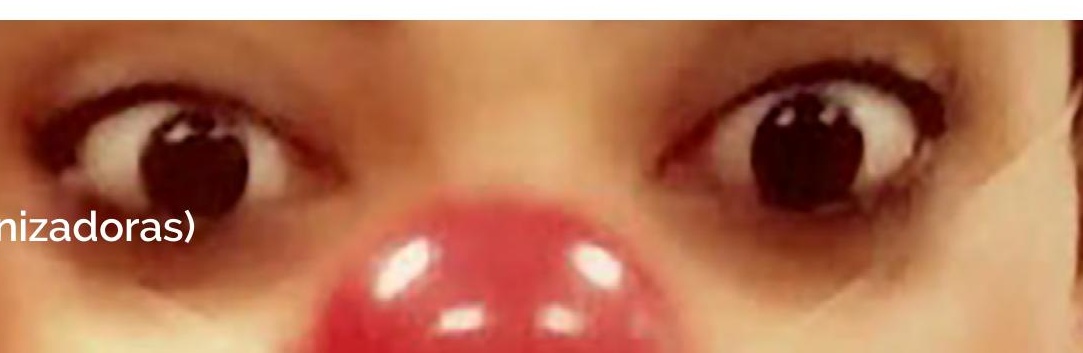


Assim, a conclusão a que chego, após as análises das trajetórias de criação cênico-pedagógicas partilhadas na função de professora-encenadora, é a de que não há uma "receita" e/ ou um método pronto para se aplicar na encenação, nem para ensinar a encenação. O trabalho de condução que é feito pelo(a) encenador(a) ou pelo(a) professor(a)-encenador(a) é algo que passa pela experiência, pelo domínio da linguagem teatral, pela artesania, e em perspectiva de revisitação e reinvenção pela técnica, pela prática da coisa em si mesma, e passa também pela intuição. A fala da encenadora-pedagoga francesa, Ariane Monouckine, com a qual estou de acordo, traduz uma proposição semelhante.

Não acredito que haja uma técnica. É provável que existam métodos, e acho que cada diretor(a) tem o seu, talvez inconscientemente. Eu tenho, um sem dúvida, mão não o conheço. A última palavra que você disse é muito importante, "escuta". Acho que sei fazer isso bem. Não chegaria a afirmar que sei, mas gosto de escutar e gosto de olhar os atores. Gosto disso apaixonadamente. Isso já é uma maneira de ajudá-los. Eles sabem que não deixo de escutálos, de olhá-los. Mas como exatamente eu os ajudo, nem imagino. (MNOUCHKINE, apud FERÁL, 2010, p. 76).

Sou como uma parteira. Eu ajudo a dar à luz. A parteira não cria o bebê. Não cria a mulher e não é o marido. Mas, se ela não estiver ali, o bebê corre sério perigo e pode não nascer. Acho que um bom diretor é isso. Vamos dizer que sou boa diretora quando não falho em sê-la. Uma parteira não é alguém que apenas observa o bebê sair facilmente. Às vezes diz: "Empurre". Às vezes diz: "Cale a boca". Algumas vezes diz: "Respire". Algumas vezes diz; "Não faça isso". Algumas vezes diz: "Tudo certo". Tudo está certo. Vamos! Vamos!" (MNOUCHKINE, apud HERITAGE 1999, p. 387)".

Em perspectiva próxima à de Ariane, sobretudo, do ponto de vista do método o processo da encenação me parece ser algo, por suas características fundantes e práxicas, mais anárquico, dialógico e pluralista. Ao mesmo tempo a encenação também é algo que passa pela experiência do fazer e pela maiêutica, e que cria um sistema

\section{Trânsitos Interdisciplinares em Artes}

Bárbara Tavares dos Santos, Liliane Scarpin S. Storniolo, Renata Patricia da Silva (Organizadoras)

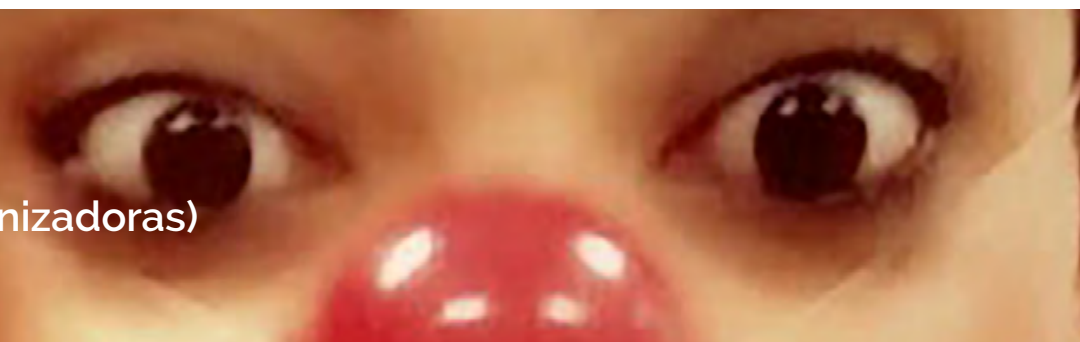


polifônico, de modo divergente e convergente, caracterizando, assim, a poética da obra de arte. Por isso, é que defendo a tese da poética da encenação como uma pedagogia cênica coletiva, mutatis mutandis, dialógica, experimental e inventiva.

Hoje, após, dezesseis anos de carreira, percebo que os processos de encenação coletivos que coordenei (e que coordeno) na função de professora-encenadora são atravessados por três instâncias de ação: mimetismo, caos e carnavalização.

O mimetismo é o processo da adaptação pelo qual um ser se ajusta a uma nova situação. Esse é o primeiro lugar de partida da criação. Nós apreendemos as coisas e o mundo, sobretudo por meio da imitação. Assim, nos primeiros processos de encenação, mimetizamos e copiamos os(as) mestres(as) que nos influenciaram e que tivemos a oportunidade de partilhar processos criativos. No estado de mimese e/ou de mímica, copiamos técnicas, procedimentos e expedientes de atuação e de composição de cenas que já são consagrados. Munidos desse arsenal, concernente à práxis teatrais diferenciadas, traçamos um roteiro de trabalho e chegamos às salas de ensaio com ideias e metodologias prontas a fim de coordenarmos e conduzirmos o processo da encenação. No entanto, no devir da construção mesma do teatro, em um piscar de olhos passamos da mímica para o caos.

A partir de certas proposições e crenças, advindas da Antiguidade clássica grega, o caos se caracterizaria em um estado geral, desordenado e indiferenciado, de elementos que antecede a intervenção demiúrgica: caracterizando-se, portanto, em etapa intermediaria da criação. Na sala de aula, nos deparamos com coletivos de estudantes, ou seja, com a dimensão do outro em todas as suas multiplicidades, belezas, feiuras e poesias. Assim, tomados por algo próximo do êxtase, muitas vezes somos arrebatados pelos acontecimentos da aula e do processo da criação, permeado por tantos saberes, desejos e sonhos: somos lançados e absorvidos pelo caos. Não é algo ruim, pelo contrário, o caos nos impulsiona ao diálogo, à dialética da reconstrução. Em meio ao caos, apreendemos a dialogar livres de certos egocentrismos em uma relação de alteridade.

\section{Trânsitos Interdisciplinares em Artes}


Nesse processo caótico da criação coletiva, quando estamos no centro do "olho do furacão", podemos até, em certos momentos, perder as referências e descobrirmos que não temos um método, tampouco uma carta mágica para tirarmos da manga. A partir de tal constatação, passamos coletivamente a deambular por diversos caminhos de criação, entrecruzando experiências, "devorando" e "digerindo" princípios, reempregando técnicas, expedientes, teoria e práticas cênicas.

Esse já é o estágio de criação do carnaval, da carnavalização. Quando a unidade coletiva, de certo modo, se constitui pela dissolução das identidades individuais. $O$ indivíduo deixa, até certo ponto, de ser ele mesmo, e se une ao coletivo, ao travestir-se por meio da fantasia e da máscara. Segundo Mikhail Bakhtin:

Na verdade, o carnaval ignora toda distinção entre atores e espectadores. Também ignora o palco, mesmo na sua forma embrionária. Pois o palco teria destruido o carnaval (e inversamente, a destruição do palco teria destruido o espetáculo teatral). Os espectadores não assistem o carnaval, eles o vivem, uma vez que pela sua própria natureza, o carnaval existe para todo o povo. Enquanto dura o carnaval, não se conhece outra vida senão a do carnaval. Impossivel escapar a ela, pois o carnaval não tem nenhuma fronteira espacial. Durante a realização da Festa só se pode viver de acordo com as suas leis, isto é, as leis da liberdade. O carnaval possui um caráter universal. Ele é um estado peculiar de mundo: o seu renascimento e sua renovação. dos quais participa cada indivíduo. Essa é a própria essência do carnaval, e os que participam dos festejos sentem-no intensamente (1987, p.6).

A analogia do carnaval com as relações entre os(as) artistas criadores(as) no processo de encenação se deve, ao fato do carnaval constitui-se em rito coletivo único em que as hierarquias são rompidas, originando uma linguagem própria de grande riqueza, e capaz de expressar uma percepção carnavalesca de mundo que se caracteriza, principalmente, pela lógica original e libertária das coisas "ao avesso", "ao contrário", pelas permutações e diversas formas de paródias e profanações. Assim, vislumbro

\section{. \\ Trânsitos Interdisciplinares em Artes}


esses três referenciais: mimetismo, caos e carnavalização como sendo estágios da criação correlatos e/ou análogos à dialética da composição que permeia o processo de construção coletiva das poéticas da encenação.

Nessa perspectiva, a compreensão e o aprendizado da encenação se perfazem nas deambulações e nos entrecruzamentos de teorias, técnicas, procedimentos e expedientes de criação cênica, vivenciados dialogicamente no coletivo. Daí emerge o entendimento da encenação, bem como da docência da encenação como um processo aberto e em gerúndio. Ou seja, o dialogismo considera as vozes dos sujeitos no discurso produzindo enunciados expressos pelas vozes humanas de forma verbal ou não verbal.

Os interlocutores são sujeitos e ao emitir enunciados e interagirem dialogicamente com a docente pesquisadora e com outros sujeitos vivenciam processos de aprendizagem. constituindo-se e fortalecendo as trocas e os aprendizados. As relações dialógicas se constroem, portanto, no encontro das vozes dos sujeitos, isto é, encontro da minha voz com a do outro. Isso porque, somos seres inacabados e por isso existe a necessidade de continuarmos aprendendo e nos formando e nos constituindo enquanto sujeitos, pois precisamos do outro para descobrir quem somos e do que somos capazes.

A proposição de ensino da encenação pensada a partir do pressuposto dialógico, e da problematização da prática docente, assim como da transformação dos aspectos que são vistos como um problema para a professora pesquisadora; e que são transformados em objeto de pesquisa é o caminho que norteia a prática docente. Nesse sentido, com esse pressuposto de ensino da encenação, concebido como prática de carnavalização, eu me coloco no lugar de quem pesquisa caminhos para transformar a sala de aula num espaço de invenção, construção do conhecimento e produção de sentidos.

Pensar uma sala de aula que ofereça diferentes espaços de interação e aprendizagem, a partir de situações cênicopedagógicas em que os estudantes se colocam no papel de encenadores(as) e vivenciem a pesquisa, a construção e a invenção

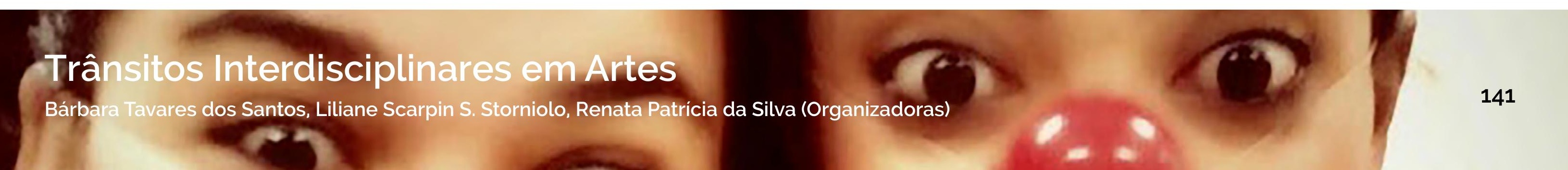


da prática da encenação teatral, considerando os principios e técnicas especificas referentes a esse labor, são os referenciais para prática docente exercida e analisada.

Assim, encontro na tessitura de experiências cênicopedagógicas a possibilidade de ultrapassar o pré-estabelecido por métodos já consagrados de encenação. Destaco aqui que pensar caminhos diferentes para o ensino da encenação que versam sobre a pluralidade metodológica na criação cênica, sobre o papel de cada sujeito no processo ensino-aprendizagem, bem como na intencionalidade, que esses pressupostos pedagógicos imprimem à formação de professores de teatro, pode contribuir para a autonomia e emancipação dos sujeitos envolvidos no processo.

\section{Referências}

BAKHTIN, Mikhail Mikhailovtch. A cultura popular na Idade Média e no Renascimento: o contexto de François Rabelais. São Paulo: Hucitec. [Brasilial: Editora da Universidade de Brasilia, 1987.

FERÁL, Josette. Encontros com Ariane Mnouchkine: erguendo um monumento ao efêmero. São Paulo, Editora SESC, 2010.

HERITAGE. Paul. Diálogos do palco: 26 diretores falam sobre teatro. Rio de Janeiro: Edição Maria M. Delgado e Paul Heritage. 1999.

SANTOS, Bárbara Tavares: Carvalho, Francis Wilker. Rastro como presença de uma ausência: Sete Movimentos dos corpos de encenadore(a)s. [Revista Rascunhos] Caminhos Da Pesquisa em Artes Cênicas, v. 6 n. 2a, 4 de abril de 2019 .

SPOLIN. Viola. O jogo teatral no livro do diretor. São Paulo: Perspectiva, 2001.

\section{Trânsitos Interdisciplinares em Artes}

Bárbara Tavares dos Santos, Liliane Scarpin S. Storniolo, Renata Patricia da Silva (Organizadoras) 


\section{A Festa de Nossa Senhora do Rosário em Monte do Carmo - TO}

Marinalva do Rego Barros Silva ${ }^{1}$ Kátia Maia Flores ${ }^{2}$

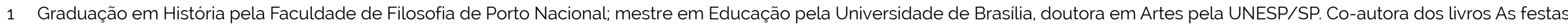

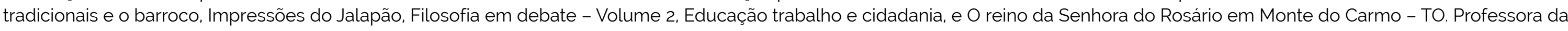
Universidade Estadual do Tocantins, e-mail: marinalva.rb@unitins.br.

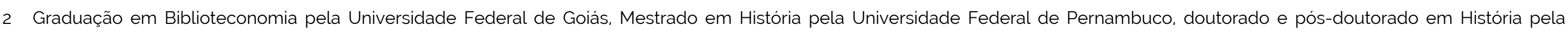

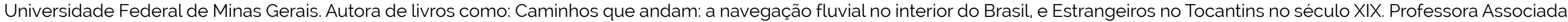
da Fundação Universidade Federal do Tocantins, e-mail: katia@uft.edu.br.

\section{Trânsitos Interdisciplinares em Artes \\ Bárbara Tavares dos Santos, Liliane Scarpin S. Storniolo, Renata Patrícia da Silva (Organizadoras)


A Festa de Nossa Senhora do Rosário é uma dentre outras festas barrocas do mundo português que aportaram nas regiões mineradoras do Brasil no século XVIII, com o propósito de promover a inserção da coroa nos novos domínios territoriais. Monte do Carmo, arraial minerador no período colonial, festeja a santa desde então, atualmente duas vezes ao ano, nos meses de julho e de outubro ${ }^{3}$. 0 municipio mantém um calendário anual de festas religiosas ligadas à igreja católica, e está localizado na região central do estado, a 96 km da capital Palmas, com densidade demográfica de 1,86 hab. $/ \mathrm{km}^{2} \mathrm{e}$ uma população estimada em 7.827 habitantes pelo IBGE.

Embora a festa de N. S. do Rosário de Monte do Carmo se inscreva no calendário litúrgico católico, ela é atravessada por elementos de outras matrizes religiosas nos diferentes momentos e

3 Em relação às duas edições anuais da festa os moradores explicam que na verdade o mês em que se comemora a santa é outubro, mas desde que as festas de Nossa Senhora do Carmo, do Divino Espírito Santo e de Nossa Senhora do Rosário foram reunidas no passado passou-se a comemoração para o mês de julho. Em 1971 a festa de Nossa Senhora do Rosário voltou a acontecer também em outubro. espaços de sua realização: das celebrações na igreja aos cantos e danças de congos e taieiras, e ao som dos tambores nas ruas.

A festa está relacionada à Irmandade de Nossa Senhora do Rosário dos Pretos que existiu no Arraial do Carmo, entidade organizadora da festa e promotora da devoção local à santa, conforme atestam estudos de Messias (2010). Por meio das festas em torno de santos e santas padroeiros, as irmandades religiosas de africanos e afrodescendentes exerceram papel determinante para a expansão e manutenção do culto católico na América portuguesa.

O período de preparação da festa representa um tempo de labor, sociabilidades e rituais; de doação de tempo, trabalho e recursos; de compromissos e papéis definidos que envolvem a comunidade como um todo. Chegado o momento do ápice, uma diversificada programação ocupa dois dias do calendário: é o tempo do rezar e do festar, no qual o espetáculo cortesão divide espaço com os cantos, danças e ritmos ancestrais. Finda a festa, ainda há muito a ser visto e compreendido no modo de ser dos que a realizam e na maneira como a encerram, olhando à frente, aguardando sua volta.

\section{Trânsitos Interdisciplinares em Artes \\ a

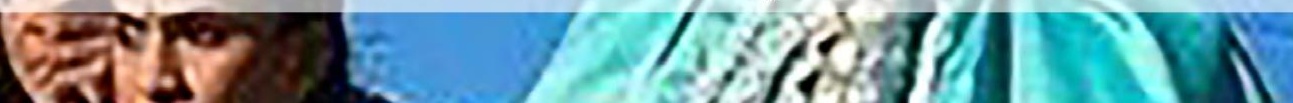


Preparação da Festa de Nossa Senhora do Rosário em Monte do Carmo

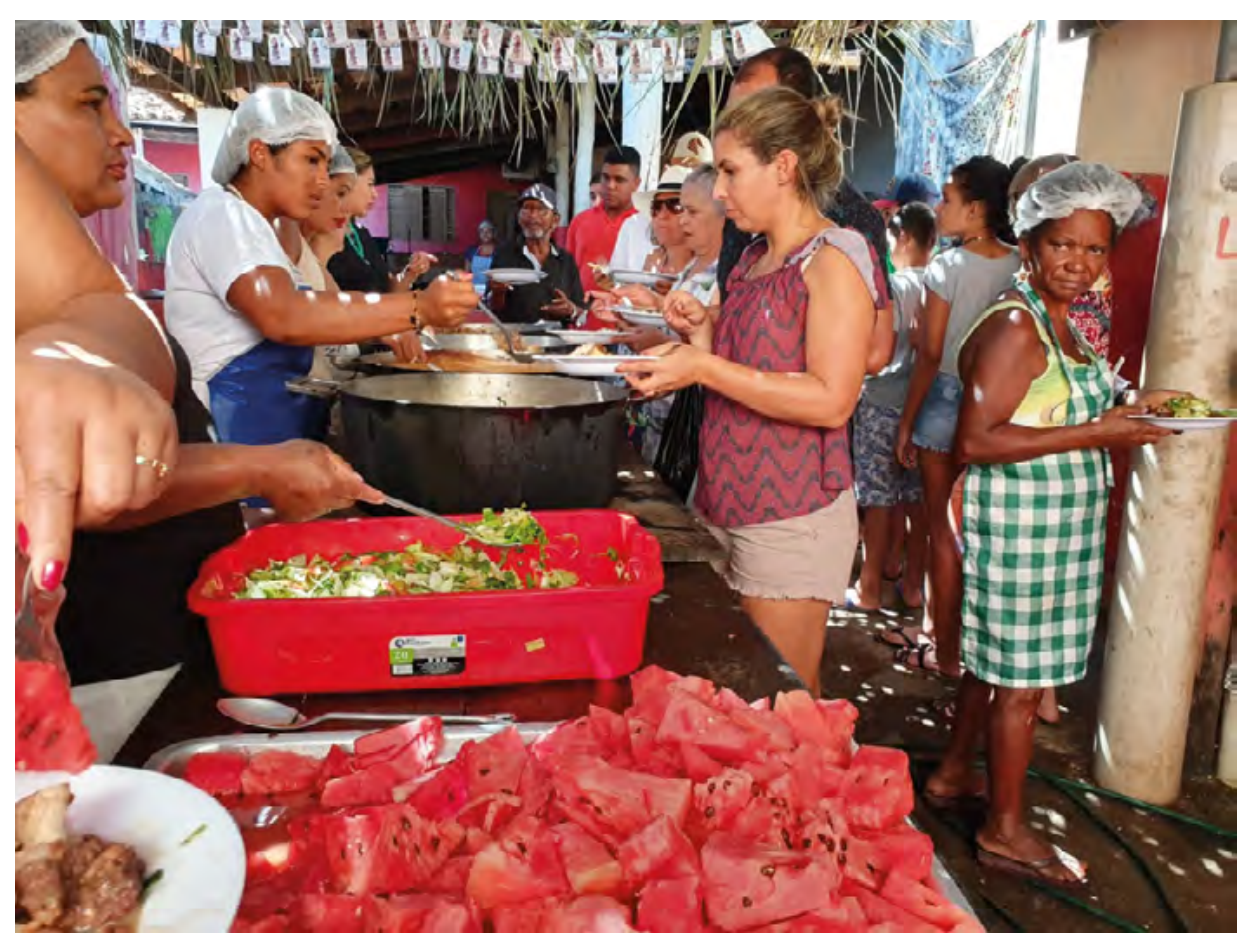

Barracão de preparação da festa de Nossa Senhora do Rosário, 2019. Monte do Carmo - TO.
"A boniteza da festa é feita pelas pessoas. Sem a participação das pessoas a festa não existe, acaba."

(Edimael Limeira de Almeida. Monte do Carmo - TO)

As engrenagens da festa de Nossa Senhora do Rosário em Monte do Carmo são acionadas um ano antes de sua realização. A cada edição, ao final da missa do último dia os festeiros do ano seguinte são anunciados e apresentados ao público. Diante da comunidade eles confirmam o compromisso, solicitam a contribuição e a participação de todos nas tarefas vindouras e relatam o motivo ${ }^{4}$ que os levaram a incluir seus nomes em uma lista

4 As motivações são várias: pagamento de uma promessa feita por alguém da familia em seu benefício por ocasião de grave enfermidade; retribuição pelo livramento de grande perigo quando se rogou o socorro de Senhora do Rosário; tradição familiar em fazer a festa; realização de um sonho; desejo de divulgar a cultura local

\section{Trânsitos Interdisciplinares em Artes}

Bárbara Tavares dos Santos, Liliane Scarpin S. Storniolo, Renata Patricia da Silva (Organizadoras)

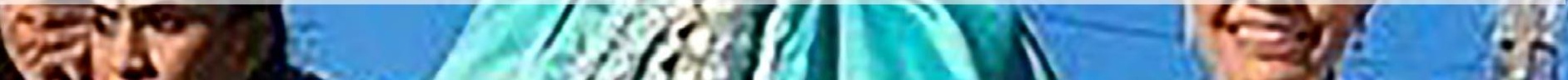
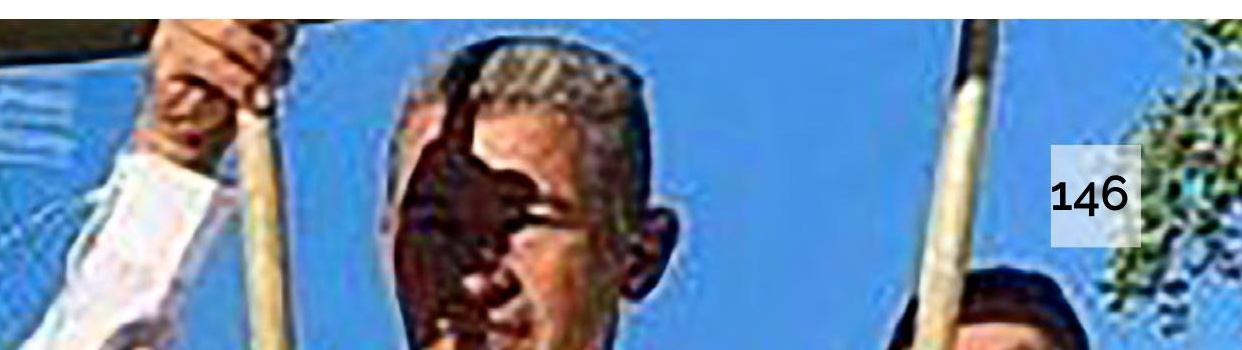
de espera que atualmente se estende para quase duas décadas à frente 5 .

Às vezes os interessados aguardam um longo periodo para a coroação. O ano anterior, após o anúncio à comunidade. geralmente é preenchido em busca de conhecimento mais específico sobre a realização da festa. Consiste em articulações com a comunidade e com os circulos familiares, profissionais e sociais, em busca de apoio e em planejamento sobre tudo o que pode ser necessário à realização do evento.

Nas entrevistas e depoimentos reis e rainhas mencionam esse período:

Em 2000 fui Rainha de Nossa Senhora do Rosário agradecendo pela cura de um câncer de mama em 1995/96. A promessa para eu ser coroada Rainha foi oferecimento da minha tia, devota de Senhora do Rosário

5 Em 2018 a lista de espera na casa paroquial agendava futuros reis e rainhas da festa de Nossa Senhora do Rosário do mês de julho até o ano de 2037. em quem depositou sua fé por mim. Terminado o tratamento fui à igreja de Nossa Senhora do Carmo dar meu nome, mas só havia vaga para quatro anos depois. Na hora achei muito distante, mas o tempo serviu para eu refletir sobre a festa e sua importância para mim. Então investi em conversas com a comunidade e em pesquisas sobre os personagens da festa e figurinos de época (AMARAL, entrevista em 2019).

Quando fui convidada pra ser Rainha da Festa de Nossa Senhora do Rosário eu comecei a buscar as pessoas mais velhas para entender como era a festa, o que a gente poderia fazer melhor (ALMEIDA, entrevista em 2018).

A Festa de Nossa Senhora do Rosário é conhecida na região como Festa da Rainha. A explicação dos moradores locais é que rainha refere-se a Nossa Senhora, a festa é de e para ela. Embora haja um casal real, a figura em destaque no imaginário local é de fato a rainha, tanto na denominação dos espaços, quanto dos ritos, e até em cantorias nas rodas de tambor.

\section{Trânsitos Interdisciplinares em Artes \\ Bárbara Tavares dos Santos, Liliane Scarpin S. Storniolo, Renata Patrícia da Silva (Organizadoras)}

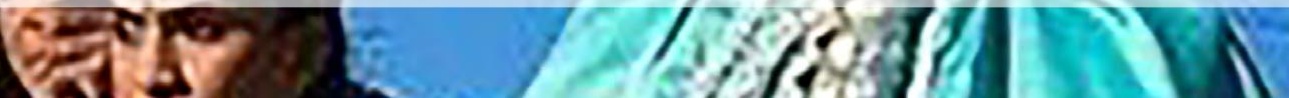
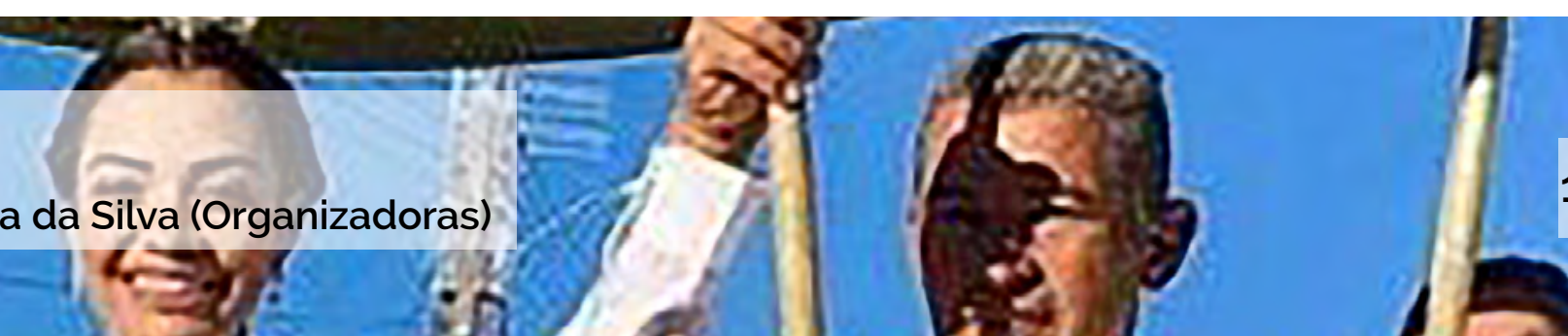
Mas, na verdade a rainha não reina sozinha, o rei é seu par e aliado na preparação e realização do evento, e com ele a rainha divide responsabilidades e custos. Frequentemente, o casal real é ligado por parentesco: irmãos ou primos é a situação mais comum, mas também não é raro que duas familias com estreitos laços de amizade e convivência se unam para fazer a festa, como relata esta rainha:

Foi dificil encontrar um rei porque a festa de Nossa Senhora do Rosário é sinônimo de gasto financeiro. Eu tinha um grande motivo para ser rainha e achava que seria fácil encontrar um parceiro que pudesse me ajudar. Ora! É o casal quem faz a festa, sem rei não há rainha. A minha família encontrou na familia Sales, moradores de Monte do Carmo, o filho de 16 anos do casal para ser meu rei. Alegaram falta de condição financeira mas acabaram aceitando e com o passar dos dias foram se envolvendo cada vez mais na realização da festa (AMARAL, entrevista em 2019)
A carmelitana Nazareth Gomes Alves (2009, p.87) elenca as atribuições do rei e da rainha, entre elas "tomar a posição do brilho da festa com liberdade e criatividade, sem ferir a tradição; tomar a postura de soberanos no espírito devoto e social". Investidos de poder real, recomenda Nazareth, devem tomar providências para que todos os rituais aconteçam com o maior fulgor possivel, além de angariar donativos e apoio da comunidade para o trabalho voluntário de preparação do evento.

Pessoas da comunidade relatam que ao longo do tempo houve mudanças sob vários aspectos, conforme os contextos econômico, social e de acesso à tecnologia apresentavam novas demandas e ou possibilidades.

Antes era tudo dentro da igreja, mas como não cabe mais eles descobriram botar a tenda fora, agora as missas é tudo fora. Cada ano eles fazem de um jeito a arrumação, cada um que faz a festa quer fazer tudo mudado, mas continua

\section{Trânsitos Interdisciplinares em Artes \\ ate

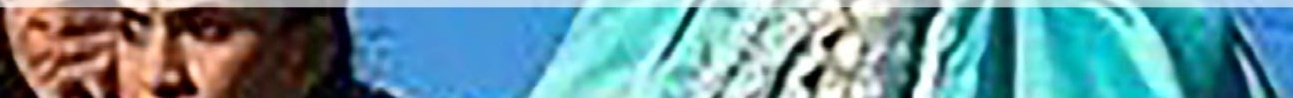


a tradição. [...] Nunca teve casa de rainha, sempre foi emprestado. Eu mesma fiz minha festa na casa de minha mãe, barraca de palha na frente com o trono; a cuzinhação foi debaixo de um pé de manga que tinha no quintal; os bolos eu trouxe da fazenda tudo pronto (NEGRE, entrevista em 2017)

Essa não é mais a realidade nos dias atuais. Os festeiros geralmente são da cidade ou de familias com origens locais que residem na região, principalmente na cidade de Porto Nacional, a uma distância de $40 \mathrm{~km}$. Mas, essa prática do passado em que os festeiros vinham do sertão é recriada nas festas do presente por meio de um evento denominado Chegada da Rainha.

A comunidade vai ao encontro desses personagens na entrada da cidade e segue-os pelas ruas, cantando e dançando ao ritmo do tambor. Os festeiros e seus acompanhantes chegam a cavalo, e há toda uma simulação do passado: carros de bois carregados de pilões, panelas e outros apetrechos, animais de cargas, pessoas trazendo peneiras e gamelas na cabeça, entre outros detalhes. Os moradores de Monte do Carmo relacionam este ritual como um revival do passado local, do modo como seus antepassados preparavam o evento festivo, e destacam que a Chegada da Rainhaé praticada hoje para não esquecer como era antes.

A arrumação da festa é pontuada de sociabilidades e de um entra e sai da casa dos festeiros, onde tem sempre uma mesa posta com iguarias para as visitas. É comum um tocador de sanfona por ali entoando músicas alegres e conhecidas e rajadas de fogos disparadas várias vezes ao dia. A rainha de 1987 relata:

Foi marcante a alegria que existiu em nossa festa e que contagiava a todos. Durante o dia, as mulheres varrendo e dançando com a vassoura, tínhamos os tocadores dentro de casa diuturnamente. Uma comadre, na época grávida de 9 (nove) meses, dançou tanto tambor na caçada e à noite que amanheceu no dia $18 \mathrm{com}$ o bebê nos braços! (ARAUJO, entrevista em 2019).

\section{Trânsitos Interdisciplinares em Artes

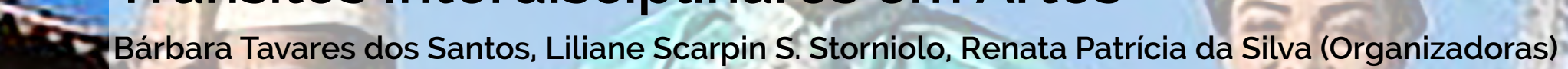

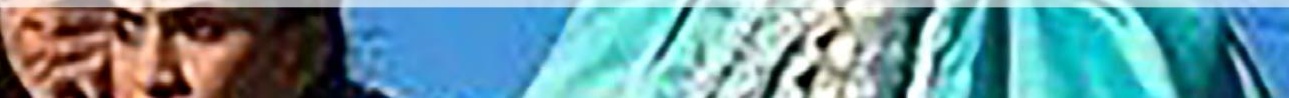
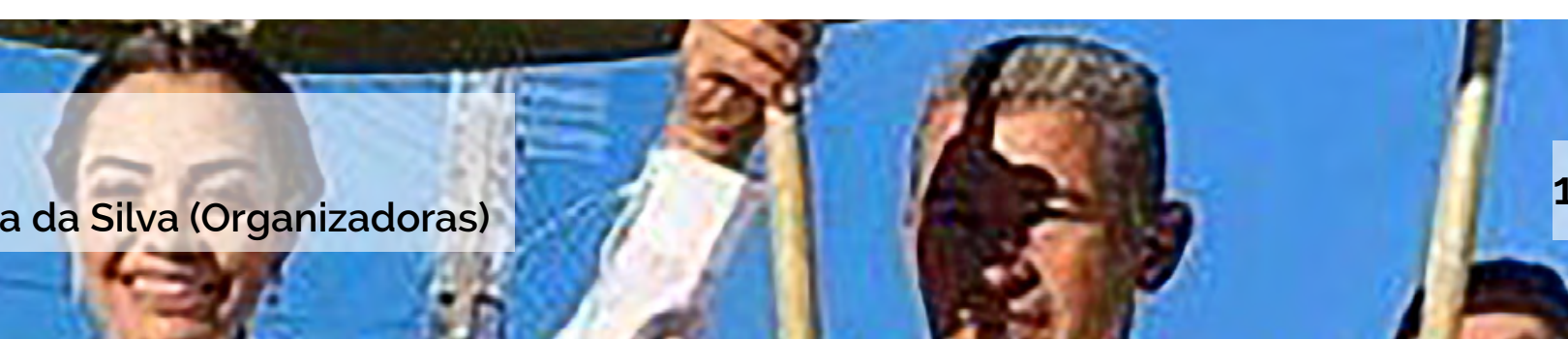
Um número expressivo de pessoas se apresenta ao rei e à rainha para prestar serviço voluntário durante cerca de vinte dias. Ora, para que isso seja possivel é necessário fazer arranjos domésticos, desembaraçar-se de compromissos familiares, sociais e profissionais, adiar ou antecipar providências da vida ordinária. E é desse modo que, duas vezes ao ano, a Festa de Nossa Senhora do Rosário é urdida em fios e tramas, em risos e labor, em um tempo cedido pelo calendário apenas para ela, recuado da vida comum. É o tempo da festa no qual tudo o mais é afastado, em que Monte do Carmo atravessa uma espécie de limiar e faz a passagem da vida comum para o reino do festejar.

\section{Tempo de Rezar, Tempo de Festar}

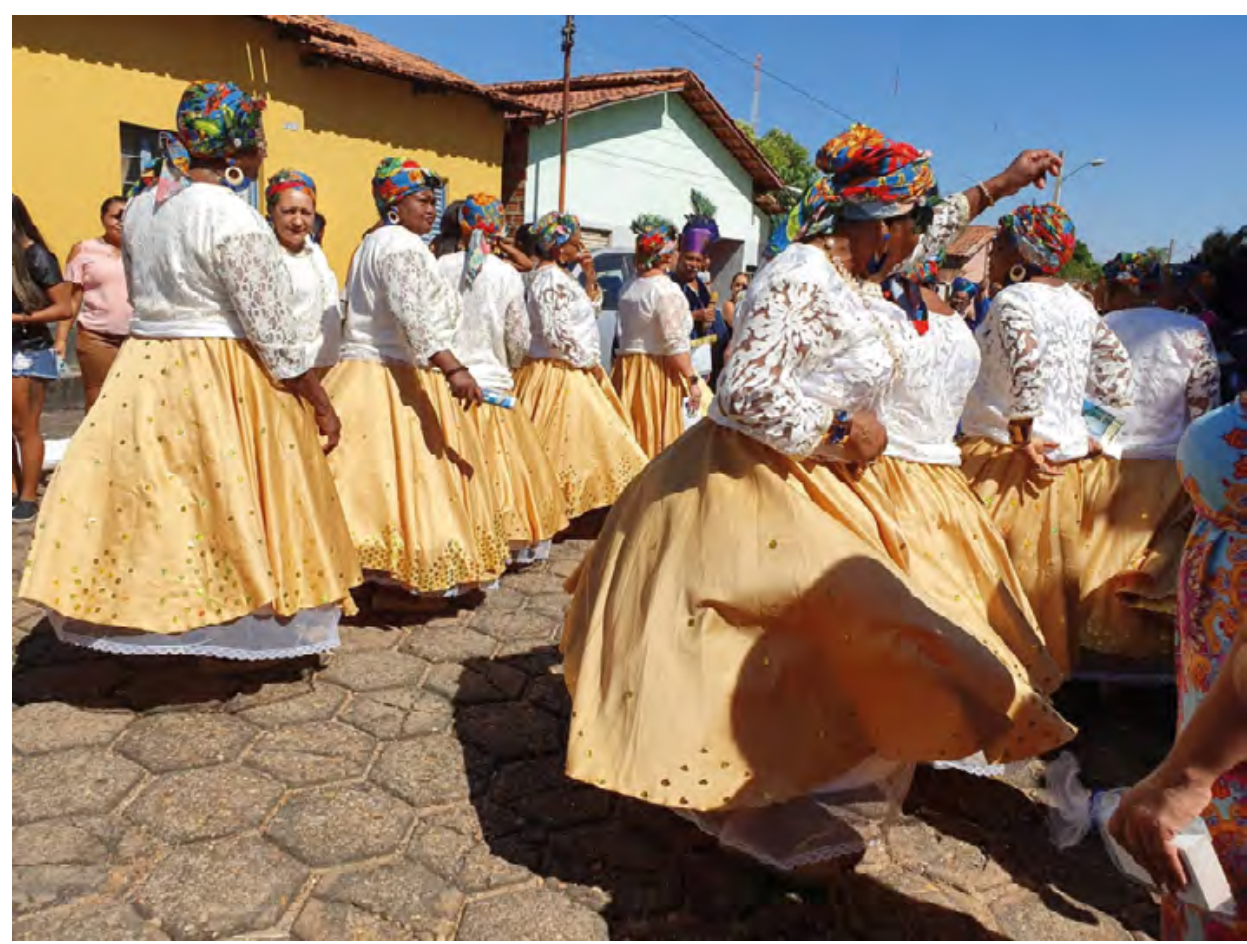

Grupo de Taieiras. Festa de Nossa Senhora do Rosário, 2019. Monte do Carmo TO

\section{Trânsitos Interdisciplinares em Artes}

Bárbara Tavares dos Santos, Liliane Scarpin S. Storniolo, Renata Patrícia da Silva (Organizadoras)

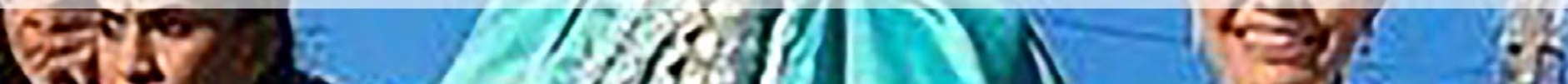
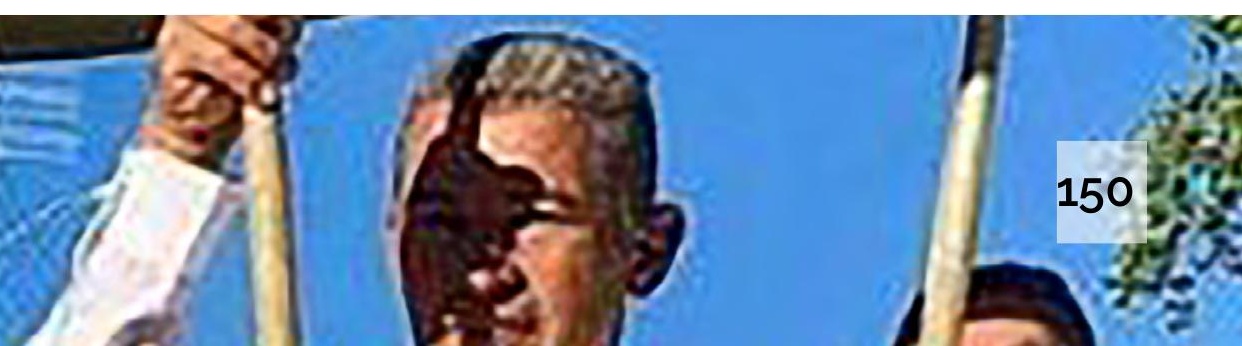
"Lá no céu tem sete estrelas mais clara do que a lua Nossa Senhora do Rosário tá passeando na rua".

(Canto das Taieiras. Monte do Carmo - TO)

Quando a Festa de Nossa Senhora do Rosário toma posse da cidade estabelece um reino intercalado pelo folgar e pelo rezar: seus súditos são devotados ao tambor e à cantoria, sempre reverenciando a divindade nas ruas, na igreja e na casa de seu reinado, recriando a cada ano as práticas transmitidas pela irmandade que cuidou dessa devoção no passado.

Segundo Brandão (1989) o devoto popular considera a festa como uma sucessão cerimonial dessas situações, para além do espaço restrito dos ritos da Igreja. Também Duvignaud (1983) aponta que a festa se apropria da rua, das praças, dos pátios, de qualquer espaço que sirva ao encontro de pessoas, fora do papel que desempenham em uma coletividade organizada. Esses são espaços que a festa utiliza para instalar-se.
Os dois dias da Festa de Nossa Senhora do Rosário têm início com o ritual da Caçada da Rainha, quando uma multidão sai pelas ruas da cidade reverenciando Nossa Senhora do Rosário ao som de tambores que impõem seu ritmo à frente do rei, da rainha e de seus acompanhantes, uma corte, talvez. Em uma pausa do longo trajeto encontram as majestades, festejam e voltam para a cidade com destino à igreja, agora com o rei, a rainha e sua corte à frente do cortejo

A Caçada da Rainha é o paraíso dos caretas. mascarados, vestidos com trajes grotescos eles correm, cabriolam, fazem gracejos, passam um cipó comprido de galho seco nas pernas das pessoas e as perseguem no meio da multidão provocando risos no público. Adoram esse jogo de brincar e causar medo, embora todos saibam que não passa de uma encenação brincalhona, uma alegre negação da identidade e do sentido único (BAKHTIN, 1987). um jogo de ridicularização e disfarces que alimentam a festa popular a céu aberto.

\section{Trânsitos Interdisciplinares em Artes


Assim, tem início a Festa de Nossa Senhora do Rosário nas ruas de Monte do Carmo: com alegria, brincadeiras e muita empolgação. Os tambores repicam, a multidão canta e dança, os caretas correm, e Senhora do Rosário é reverenciada pelo povo com seus tambores, suas danças e cantos, e sua devoção alegre.

A partir da Caçada da Rainha, a festa de Nossa Senhora do Rosário ocupa os espaços da cidade durante dois dias. Uma parte transcorre na igreja: missas e coroação dos festeiros; outra acontece nas ruas: canto e dança ao ritmo do tambor, atuação de caretas, cortejos, apresentação de grupos de congos e de taieiras; e outra parte é reservada à casa da festa: recepção ao público com mesas longas repletas de bolos de variados sabores e formatos; bailes e banquete.

Brandão (1989) define bem esse universo festivo quando destaca que uma festa popular é essa mistura espontânea e ao mesmo tempo ordenada de rezar, cantar, dançar, desfilar, enfim, de festar, termo que expressa tudo o que deve realmente acontecer em uma festa do povo: uma multiplicidade de festejos que tomam conta da rua.

Encerrada a Caçada da Rainha ao final da tarde, os festeiros preparam-se para a sequência da festa. No início da noite saem de casa vestidos a rigor, acompanhados por familiares, amigos e conhecidos em direção ao local onde os aguardam o casal real do ano anterior ${ }^{6}$, também vestidos com pompa, usando as coroas e os cetros de prata7 e adornados com mantos cerimoniais.

6 O local desse encontro não é fixo, pode ser em frente à residência de familiares do rei ou da rainha, como pode ser em um local estratégico nas ruas do centro da cidade.

7 Conforme informações obtidas na Casa paroquial durante a pesquisa, as coroas e os cetros teriam pertencido à Irmandade de Nossa Senhora do Rosário dos Pretos que, a exemplo de Portugal, existiu em Monte do Carmo. A prova mais contundente de existência dessa agremiação como organizadora da festa e difusora da devocão à santa na localidade é um conjunto de documentos que, embora de dificil visualização e fragmentados, registram doação de recursos à irmandade e prestação de contas da mesma. Ver mais sobre o assunto em Messias, Noeci Carvalho. Religiosidade e devoção: as festas do Divino e do Rosário em Monte do Carmo, TO. Goiânia: Espaço Acadêmico, 2016.

\section{Trânsitos Interdisciplinares em Artes \\ Bárbara Tavares dos Santos, Liliane Scarpin S. Storniolo, Renata Patrícia da Silva (Organizadoras)

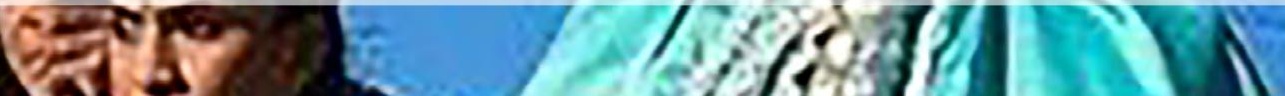


Após cumprimentarem-se, reis e rainhas seguem em direção à igreja em cortejo, acompanhados por muitas pessoas portando velas acesas, ao som de uma banda de música e de fogos de artifício durante o trajeto. À porta das grandes tendas instaladas ao lado da igreja de Nossa Senhora do Carmo, e onde desde o ano de 2004 são celebradas as cerimônias religiosas nas festas do mês de julho, os sacerdotes aguardam os casais reais.

Os reis ajoelham-se, o sacerdote que preside a cerimônia apresenta uma cruz que o rei coroado e o novo rei beijam com reverência. Em seguida a coroa é transferida do rei velho para o rei novo, como a comunidade os denomina, o mesmo acontecendo com o cetro e o manto, quando é o caso ${ }^{8}$. A cerimônia segue seu

8 Na maioria dos casos os mantos cerimoniais são produzidos pelos próprios festeiros, nesse caso o rei e a rainha que passam a coroa continuam usando seus mantos em todos os ritos da noite. Quando porém os festeiros não trazem seus próprios mantos para a cerimônia de coroação o sacerdote transfere também essa insignia real, juntamente com a coroa e o cetro. Muitos festeiros, tanto do Divino quanto de Senhora do Rosário fazem doação de seus mantos à igreja e eles são usados por empréstimo em outras festas. curso com a coroação da rainha, nos mesmos moldes da coroação do rei.

Após a coroação os dois casais reais fazem a entrada na igreja, com os reis coroados à frente, e a missa tem início. A ornamentação do local é responsabilidade dos festeiros que, diferentemente do passado, contratam decoradores profissionais da região especializados em festas religiosas.

Maravall (1975) destaca que a festa barroca no século XVII, era marcada pela pompa, ostentação e aparatos, e conferia grandeza àquele que a tornava possivel. Era uma festa feita para deslumbrar, provocar efeitos, ser vista por todos. Semelhante ao que se presencia em Monte do Carmo por ocasião das festas do Divino e do Rosário. Para Mary Del Priore,

Misto de sagradas e profanas, estas festas vulgarizaram ainda um comportamento extremamente devoto por parte das populações coloniais, acentuando a identificação entre Igreja e Estado. O rei e a religião, numa aliança

\section{Trânsitos Interdisciplinares em Artes \\ Bárbara Tavares dos Santos, Liliane Scarpin S. Storniolo, Renata Patrícia da Silva (Organizadoras

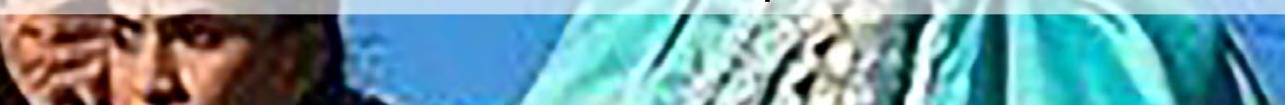


colonizadora, estendiam o seu manto protetor e repressor sobre as comunidades (PRIORE, 1994, p. 14-15).

Segundo a autora, a festa efetivamente possibilitava ao grupo social o confronto de privilégios de prestígio e rivalidades, a exaltação de posições e valores, de privilégios e poderes. Tudo reforçado pela ostentação do luxo e distribuição de larguezas.

Ao final da missa há um cortejo até a casa da festa, também decorada, onde é servido café com bolo seguido de um baile. Os reis e rainhas (novos e velhos) ocupam um trono onde são reverenciados e presenciam a festa do povo. No dia seguinte o rei e a rainha recebem para o café da manhã os grupos afro-brasileiros de congos e de taieiras que os acompanham para a missa solene de Nossa Senhora do Rosário e depois os trazem em cortejo pelas ruas de volta para a casa da festa.

A apresentação de congos e taieiras é a atração mais expressiva na festa de Nossa Senhora do Rosário nesse dia. Com cantos e danças, roupas coloridas e adornos na cabeça reverenciam o rei e a rainha e expressam a devoção à santa nos espaços não litúrgicos da festa, alternando-se nos cantos e danças com avanços e recuos para que cada grupo no cortejo apresente-se.

o grupo de congos é formado por doze homens que cantam e dançam juntos há vários anos. Usam instrumentos de percussão de fabricação própria como reco-reco, pandeiros e caixas, e revelam que a entrada para o grupo muitas vezes tem a ver com a influência de um parente ou com o desejo de participar de uma tradição.

Fui ser congo mais pela tradição. A gente vê eles apresentando todo ano, ai um dia minha mãe falou comigo "você podia dançar congo", eu fiquei com aquilo na cabeça ai resolvi e continuei até hoje. muitos anos dançando congo. Digo assim que a festa da rainha é uma festa tradicional, foi deixada pelos escravos, tem esses reinados, tem os reis e as rainhas, tem os congo e as taieira (SANTOS, entrevista em 2017).

\section{Trânsitos Interdisciplinares em Artes

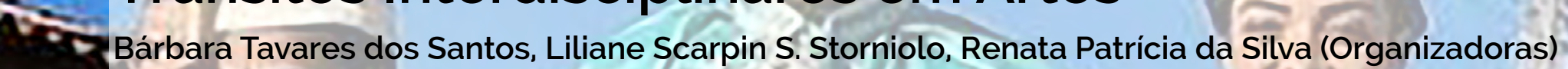


Na verdade, desde o final do século XVI era permitido aos negros das irmandades em Portugal reportarem-se às suas origens em cerimônias festivas referentes aos reis do Congo. Entretanto, somente a partir do século XVIII eles começaram a aparecer como músicos nas procissões e cerimônias religiosas (Tinhorão, 2012), passando a ser uma tradição a presença dos africanos com seus atabaques e tambor nas procissões e cortejos. Com o tempo, essa presença também faria parte das festas oficiais.

Além de músicos, eles estavam inseridos no território do simbólico e do religioso em Portugal, uma vez que se tornaram presença indispensável na mais importante celebração católica lusitana, que exigia a participação de todas as Confrarias: a
Procissão do Corpo de Cristo ${ }^{9}$. Manoel Querino considera que o "africano já trazia a seita religiosa de sua terra; aqui era obrigado. por lei, a adotar a religião católica. Habituado naquela e obrigado por esta, ficou com as duas crenças" (QUERINO, 2010, p.50).

Na opinião de Henriques (2011), não deixa de ser singular a situação de confiar aos africanos a produção musical das festividades, abrindo espaços de espetáculo e de diversão de rua que passaram a ser indispensáveis ao brilho dos eventos.

Estamos perante um processo de 'africanização' de um ritual católico, pois a música e a dança não eram apenas manifestações lúdicas africanas, mas faziam parte da relação social entre os homens, organizando também as

9 A origem desta cerimônia remonta ao final do século XV, a partir de dois elementos: o de natureza religiosa teria sido inspirado nas várias trasladações, pelos judeus, da Arca da Aliança que guardava os mandamentos, com música, festa e alegria; o segundo, de natureza histórica, relacionava-se à Batalha de Aljubarrota em 1385, como ato de ação de graças pela vitória militar portuguesa sobre os castelhanos. Ver TINHORÃO, José Ramos, Festa de negro em devoção de branco, São Paulo: Ed. Unesp, 2012.

\section{Trânsitos Interdisciplinares em Artes
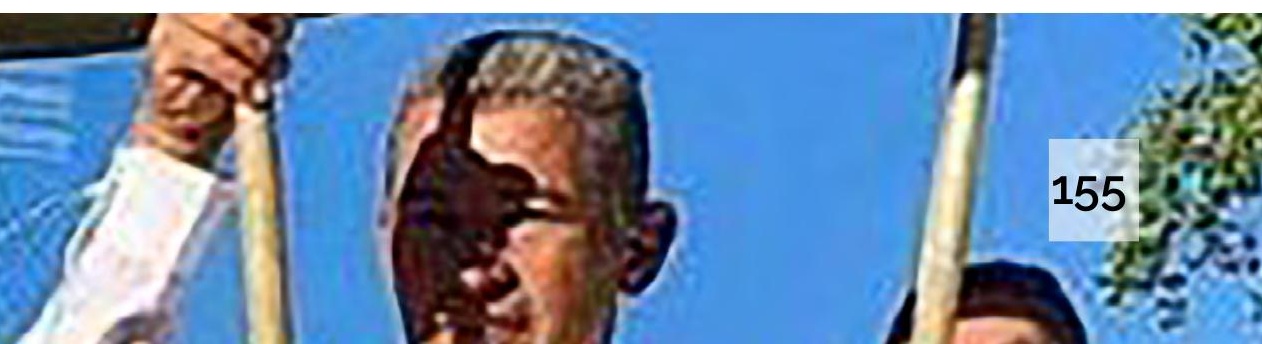
relações com as divindades. As procissões, acontecimentos religiosos, lúdicos, sociais - revelando as hierarquias sociais e o poder econômico -, organizavam-se em honra de figuras dos cultos católicos, como Nossa Senhora do Rosário, ou o Corpo de Deus, marcado pela grandiosa procissão do Corpus Christi (HENRIQUES, 2011, p. 49).

Souza (2002), ao estudar a coroação dos Reis de Congo nos séculos XVIII e XIX, identifica continuidades de práticas rituais do culto a Nossa Senhora do Rosário com religiosidades africanas. Segundo a pesquisadora, o êxito do culto a Nossa Senhora do Rosário entre os negros pode ser explicada também pela possivel identificação do rosário com objetos mágicos constituintes da religiosidade africana. Compelidos pela diáspora a se integrarem a uma nova terra, muitos africanos acabaram por perceber novas identificações e construir novas identidades ancoradas em bases diversas, principalmente a religião.

A capacidade de unir o devoto diretamente ao alvo de sua prece também é abordada por Tinhorão (2012), no entendimento de que o catolicismo foi integrado às comunidades negras por meio das exterioridades do culto, e não pela assimilação dos conceitos teóricos da fé. Para ele os negros elegeram Nossa Senhora do Rosário para objeto de culto, principalmente por terem estabelecido uma relação direta entre seu rosário e o rosário de Ifá, usado por sacerdotes africanos.

Em Monte do Carmo, tanto os congos quanto as taieiras não se reúnem fora do espaço da festa. Eles relatam que guardam seus figurinos e aguardam a festa vindoura quando os próximos reis e rainhas os procuram para combinar sobre detalhes de novos trajes ou ornamentos.

As informações a respeito das taieiras em Monte do Carmo antes de 1979 são vagas. Depois de cerca de trinta anos sem se apresentarem na festa de Nossa Senhora do Rosário, a rainha daquele ano, Sonia Pereira de Almeida, reuniu algumas remanescentes e juntas recuperaram cantos, danças e a lembrança de figurinos, trazendo de volta essa parte da festa que estava esquecida. Desse modo, no último dia da festa, congos e taieiras

\section{Trânsitos Interdisciplinares em Artes \\ $=$

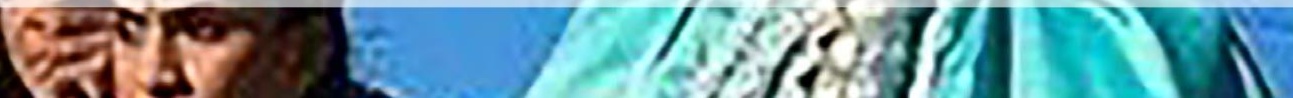

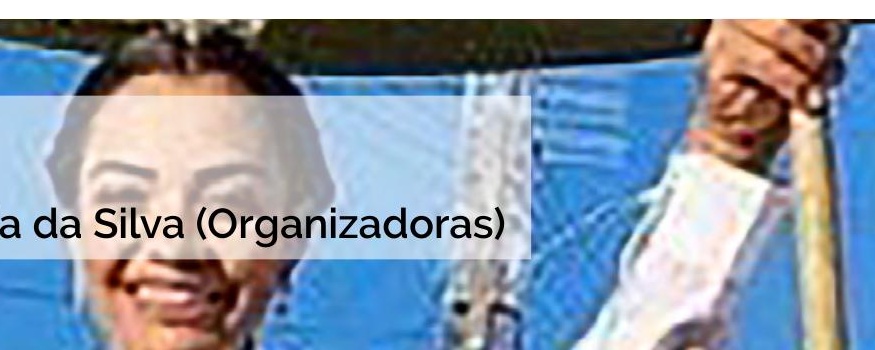

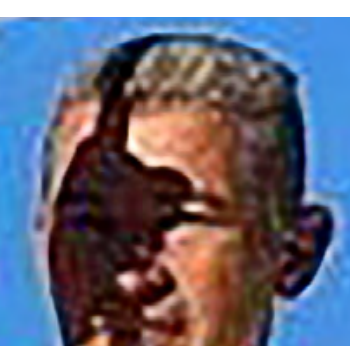

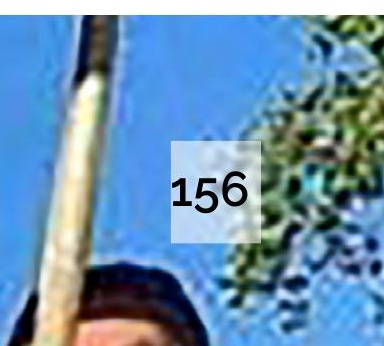


conduzem o rei e a rainha com cantos e danças pelas ruas da cidade até o local de celebração da missa solene de Nossa Senhora do Rosário.

Os sacerdotes aguardam o cortejo na entrada do templo adaptado: congos e taieiras se posicionam dos dois lados da entrada formando uma espécie de guarda de honra, e a pessoa responsável pelo cerimonial da celebração anuncia a presença do rei e da rainha de Nossa Senhora do Rosário, conclamando todos os presentes a se levantarem para recebê-los.

O casal real faz sua entrada solene no recinto seguido pelos congos, taieiras, capitã do mastro e sacerdotes, ao som do hino de louvor à santa entoado pelo público. Antes do encerramento da cerimônia os sacerdotes cedem espaço para depoimentos dos festeiros e familiares, onde a experiência vivida é relatada.

[...] Sinto-me honrada pela oportunidade de viver essa tradição, essa cultura que perpassa gerações e se fortalece em seus princípios e valores através da reverência ao sagrado e a sabedoria popular, revivendo cantos, danças, cultos, e culinária, permanecendo e se mantendo dentro do espaço sagrado, pontos de conexão com nossas origens, de forma vibrante, pulsante e mágica. Minha sincera gratidão a toda a comunidade pelo acolhimento e pela dedicação à manutenção dessa cultura. Que ela permaneça entre nós (CHAVES, rainha 2019).

Após os depoimentos são distribuidas lembrancinhas da festa, algo delicado relacionado à devoção a Nossa Senhora. O último momento da celebração, antes da benção final, é reservado ao anúncio e apresentação dos festeiros do ano seguinte à comunidade. Ao final da missa todos saem do recinto para o cortejo pelas ruas, animado pelos grupos de congos e de taieiras e pelo grupo do tambor.

A casa da festa recebe todos os acompanhantes do cortejo com uma longa mesa onde é servido café com bolo; os reis sentam-se no trono onde são reverenciados, acompanhados pelos festeiros do ano seguinte. Após o café com bolo, baile e roda de tambor, a festa é finalizada com um banquete onde todos são

\section{Trânsitos Interdisciplinares em Artes}


convidados: congos, taieiras, amigos, trabalhadores voluntários, boleiras, sacerdotes, gestores municipais, doadores de recursos, reis, rainhas e imperadores de festas passadas, visitantes, romeiros, turistas, pesquisadores e quem mais aparecer.

Assim, termina cada festa de Nossa Senhora do Rosário em Monte do Carmo, após dois dias de atividades intensas, precedidos por semanas de preparação. Como se nesse lugar. por um pequeno recorte de tempo, as pessoas se dispusessem a desnudar-se de seus papéis sociais e vivenciar certa plenitude. com a intenção talvez de lembrar que a vida não se encerra em apenas uma dimensão imposta pelos valores do utilitarismo e da rentabilidade. Dificil não pensar na recomendação de Marta Campos: "[...] quando estivermos participando das festas do Carmo, saberemos que, embora apenas um momento renovado anualmente, elas são antes o coroamento de um longo tempo de festa e de trabalho" (CAMPOS, 1988, p. 51).
A Festa Termina, outra é Esperada

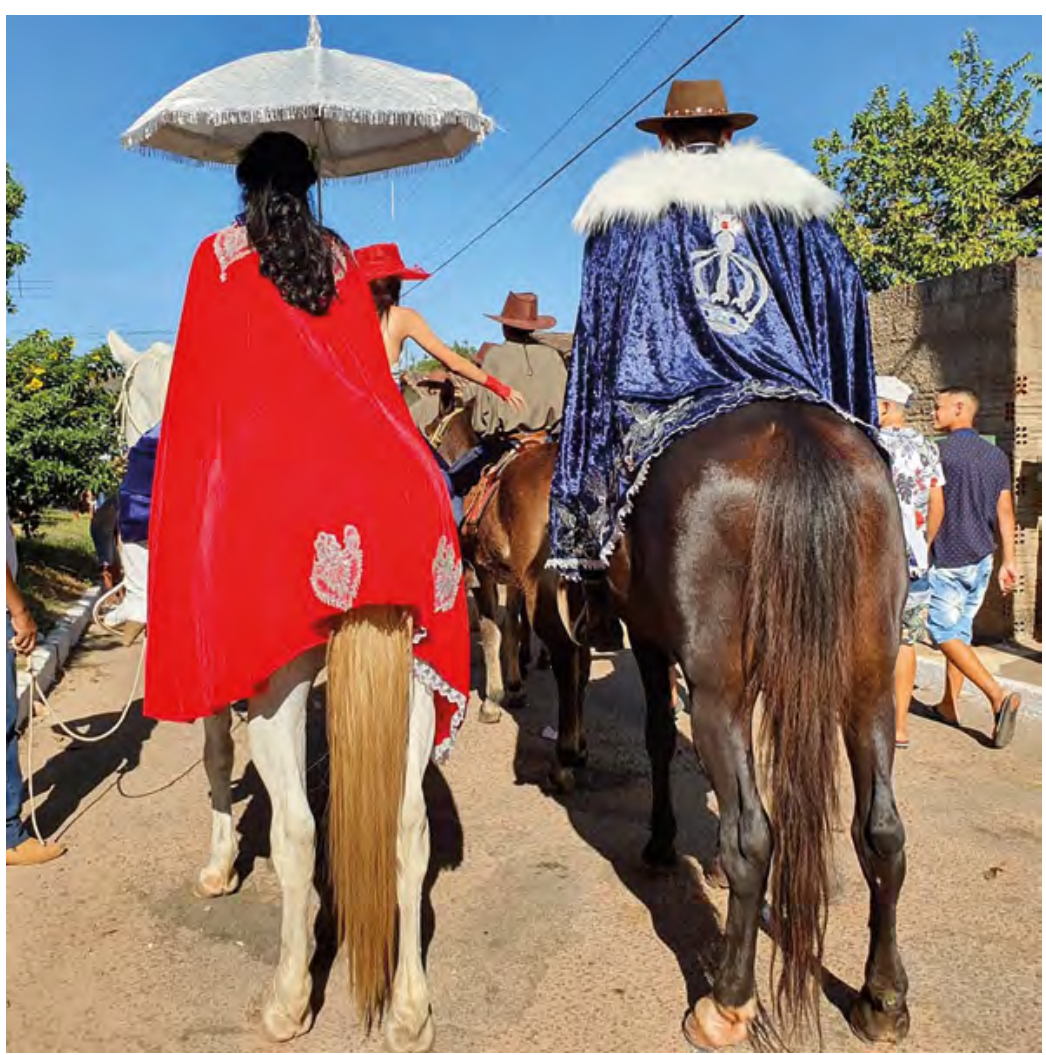

Rei e Rainha - Festa de Nossa Senhora do Rosário, 2019. Monte do Carmo - TO.

\section{Trânsitos Interdisciplinares em Artes}

Bárbara Tavares dos Santos, Liliane Scarpin S. Storniolo, Renata Patrícia da Silva (Organizadoras) 
"Conto os dias para a próxima Caçada da Rainha, quero estar lá fazendo parte da história da comunidade"

(NERES, 2019. Careta - Monte do Carmo - TO)

A festa de Nossa Senhora do Rosário foi cumprida mais uma vez e Monte do Carmo ficou modorrenta e silenciosa. Acompanhar o desmonte do tempo e do espaço cortesão que habitou a cidade nas duas primeiras semanas de julho ou de outubro pode causar certa nostalgia, mas também traz a compreensão de que ali, uma festa que finda gesta outra que virá. Ela não termina sem que uma nova seja prometida. E esperada.

Callois (1988) entende que é compreensivel que a festa atravesse a existência cotidiana do indivíduo com a força das emoções intensas, ao mesmo tempo em que ficam esmaecidas as atividades diárias que ocupam seu tempo. Embora comprometido com essa vida que o sustenta, alimenta-se da lembrança de uma festa e da espera de outra, pois que ela representa o tempo permitido à intensidade de suas emoções e a transformações de seu ser

Qualquer criatura que permaneça em Monte do Carmo no pós-festa pode sentir-se tentado a indagar: que brumas ocultaram a cidade da festa? Que relógios e calendários reinstalaram o tempo da vida comum? Congos, taieiras, caretas e majestades não trafegam mais pelas ruas: retomaram seus papéis de servidores públicos, agricultores, estudantes, profissionais autônomos.

Os tambores, reco-recos, pandeiros e caixas silenciaram. As tendas que receberam o cenário de celebrações faustosas ao lado da antiga igreja foram desmontadas; decoradores recolheram da igreja, da casa da festa e das ruas os artifícios utilizados no processo de recriação de imagens e representações: tecidos, painéis, luminárias, flores, estruturas móveis, artefatos de iluminação.

Coroas, cetros e a cruz gloriosa, legados da Irmandade de Nossa Senhora do Rosário dos Pretos aos devotos de Monte do Carmo foram guardados em lugar seguro. Na casa da rainha,

\section{Trânsitos Interdisciplinares em Artes \\ redos

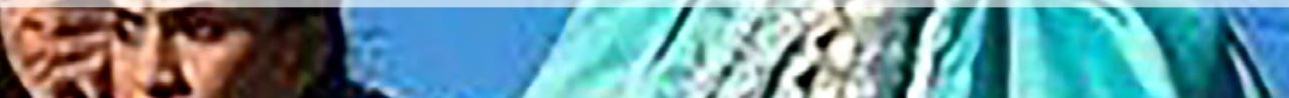
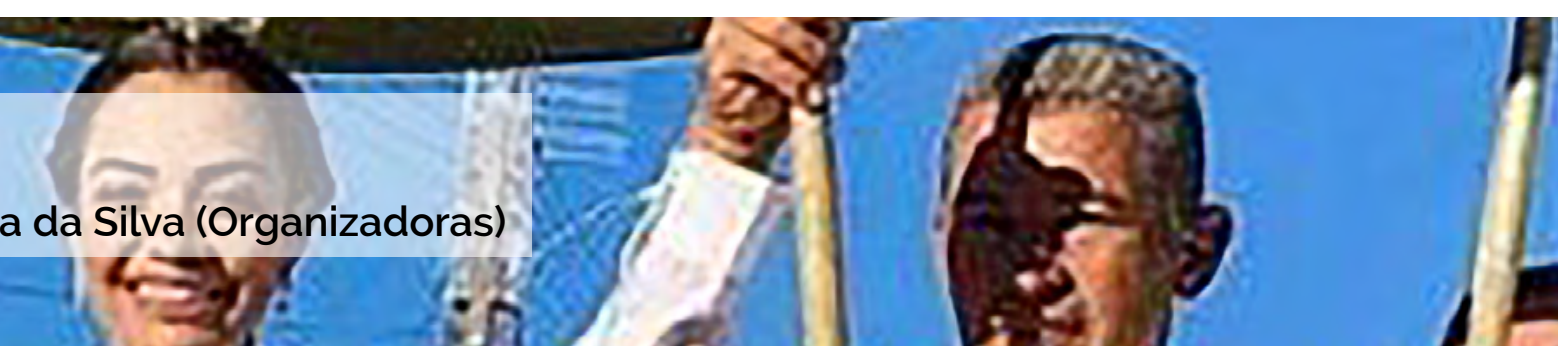
familiares e auxiliares diretos embalaram e retiraram móveis, rouparia, utensilios e apetrechos, que durante cerca de vinte dias serviram ao propósito de transformar uma residência local na casa de preparação e realização do evento festivo.

Vasilhames e utensilios tomados de empréstimo foram devolvidos à comunidade: panelas, tachos, gamelas, peneiras, facas, facões, tabuleiros e formas de assar bolos, liquidificadores, batedeiras e processadores, freezers, geladeiras, fogões industriais, entre outros itens.

A barraca de palhas, antes um espaço fervilhante de atividades na fabricação dos bolos foi desmontada; mesas rústicas estilo cavalete, jiraus e bancos, agora sem serventia nessa casa desabitada foram levados por pessoas interessadas em reaproveitálos de outras maneiras. Fornos de barro foram desfeitos para que o terreno fosse devolvido sem vestígios. Lenhas e gravetos que sobraram foram doados para acudir a precisão de alguém.

A casa foi lavada, escovada, vasculhada do chão ao teto para ser entregue. Tudo nela foi retirado, devolvido, embalado ou doado. A casa da rainha não existe mais, voltou a ser o endereço de um dos moradores da Rua Coronel Carolino.

Ouvir os participantes e realizadores da festa expressarem seus sentimentos sobre o encerramento do tempo festivo e a retomada da vida ordinária remetem-nos às impressões de Campos (1988, p. 51), quando registrou, ao final de sua pesquisa que o tempo da festa se estende e se repete, e que "nas horas suspensas das festas do Carmo se celebra e se pronuncia de forma mítica a existência de um mundo de abundância", união e harmonia, vivido e repetido.

Não os vimos falarem de tempos findos, experiências irrepetiveis. Em vez disso, proclamaram a emoção vivida e a expectativa futura de viver tudo de novo, com a certeza de que nada será igual.

A festa não é passado para aqueles que a vivem em Monte do Carmo, não se encerra em si mesma. Ela transcende os dias marcados no calendário, é um vir a ser, uma promessa com garantias de ser cumprida: pelos fiéis depositários da lista de espera

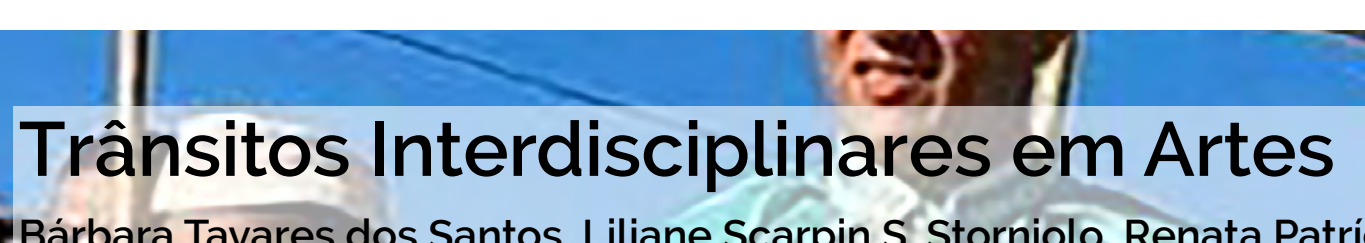 \\ a $\sin$

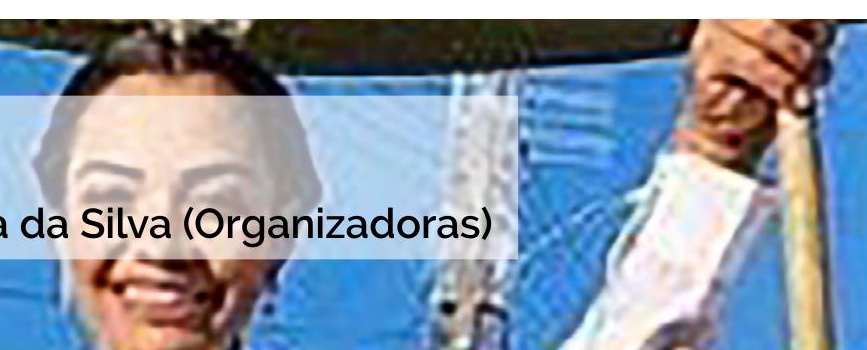

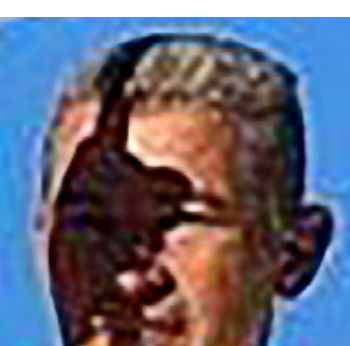

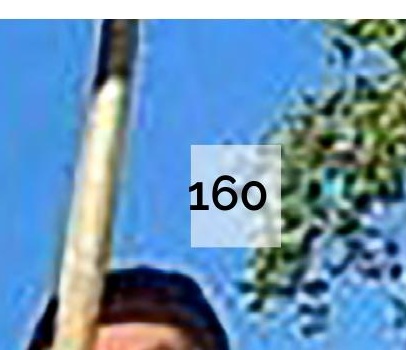


na casa paroquial, e pela comunidade, que guarda a sabedoria de como realizá-la "com liberdade e criatividade, sem ferir a tradição", como recomenda a carmelitana Nazareth Gomes Alves. Os participantes, brincantes, realizadores e voluntários olham para a frente e vislumbram a próxima festa, enquanto retomam suas vidas.

\section{Considerações Finais}

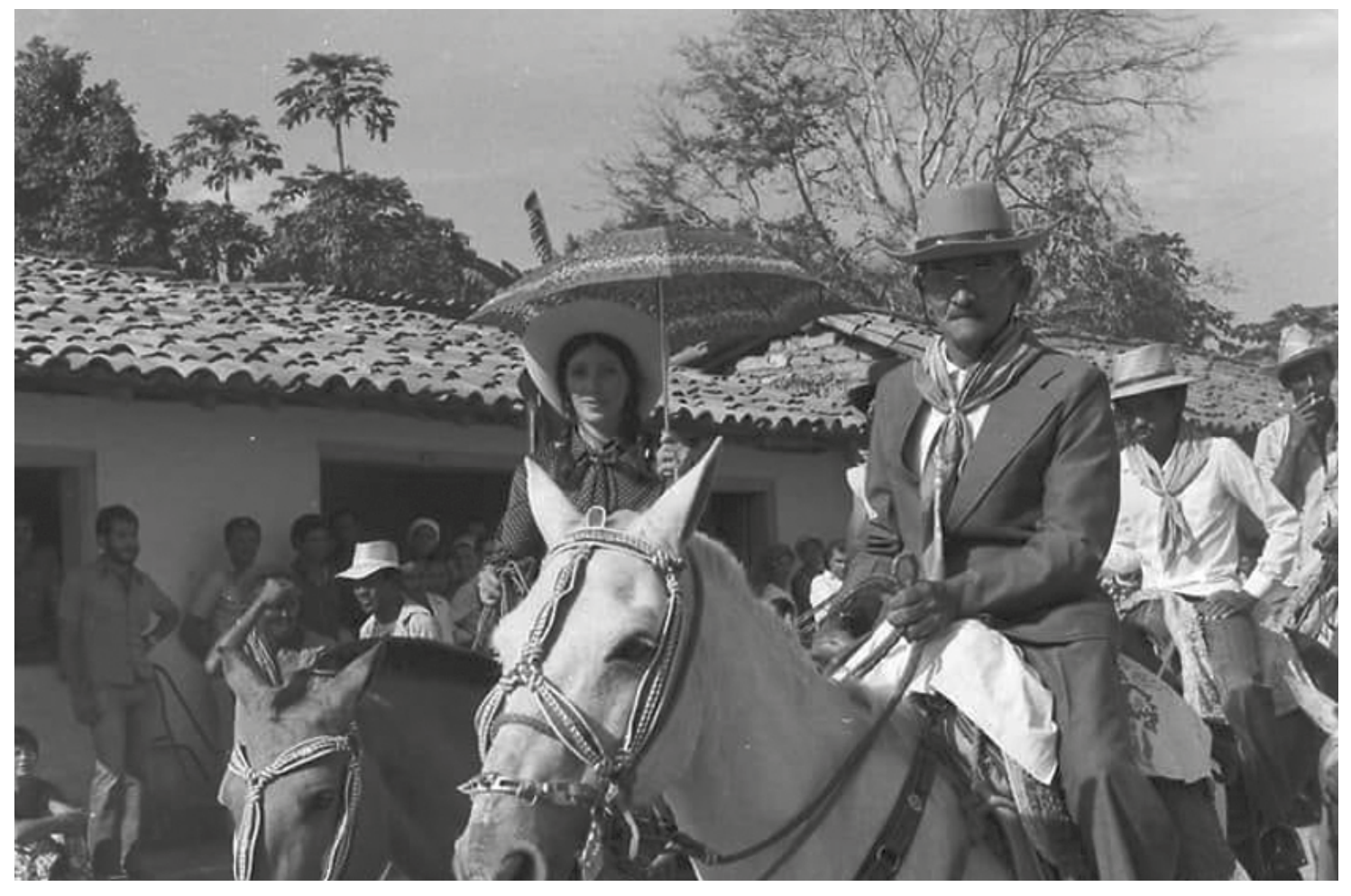

Caçada da Rainha, 1979. Acervo da família Pereira Almeida. Monte do Carmo - TO.

\section{Trânsitos Interdisciplinares em Artes}

- Bárbara Tavares dos Santos, Liliane Scarpin S. Storniolo, Renata Patrícia da Silva (Organizadoras)

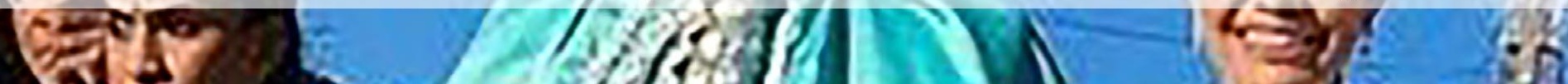
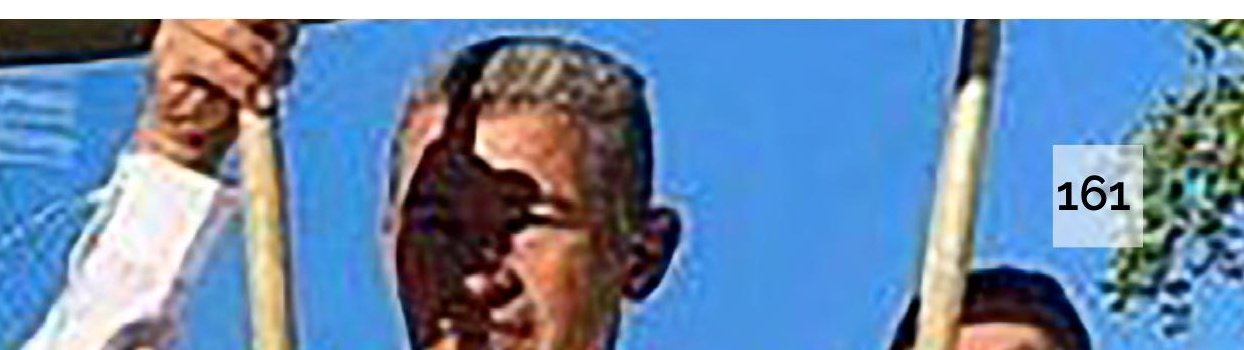
É visivel o sentimento de pertencimento da comunidade de Monte do Carmo em relação à Festa de Nossa Senhora do Rosário, participando e se envolvendo em todo processo de preparação e realização à frente da gestão do evento. A igreja católica detém o controle sobre as cerimônias religiosas e os rituais relacionados a ela, como a coroação dos festeiros, por exemplo, mas em todos os outros aspectos a Festa de Nossa Senhora do Rosário é gerida pela comunidade e pelos ocupantes do papel principal: o rei e a rainha, como nos tempos da irmandade.

Aos personagens do enredo, juntam-se muitos outros com seus diferentes ofícios e saberes, assumindo trabalho voluntário na casa dos festeiros. É perceptivel uma forte adesão das pessoas com o tempo da festa, alterando o cotidiano de suas vidas e assumindo papéis e responsabilidades para que ela se realize. Essa espécie de compromisso em fazer com que a festa aconteça, "com boniteza" como assinala o menino Edimael, aparece a todo momento nos depoimentos, como um dever para com Senhora do Rosário considerada Rainha e anfitriã da festa.
Mas, em um ponto a concordância é geral: a tradição da festa, naquilo que compõe seu roteiro há gerações, tem sido mantida, e isso aparece como mais importância para eles do que o fato de ela ser mais glamurosa ou mais simples. Segundo os depoimentos, a beleza da festa reside na manutenção de sua tradição: na Caçada da Rainha, nos cortejos e reinados, nas missas e na coroação, nas mesas de bolos tradicionais, nos rituais de preparação, nas rodas de tambor. Desde que a tradição não seja rompida, consideram que a festa será sempre bonita.

A festa é de todos que a ela comparecem: reis e rainhas reiteram em suas falas quão importante é a vinda de pessoas de todos os lugares, assim como a participação da cidade. Quem faz a festa entende que quanto mais pessoas estiverem presentes, quanto mais gente se alimentar do que foi produzido e servido. tanto melhor ela será.

As sociabilidades significam essa troca, esse acolhimento, essa fartura compartilhada. As pessoas mudam suas rotinas para participarem do longo periodo de preparação da festa porque se

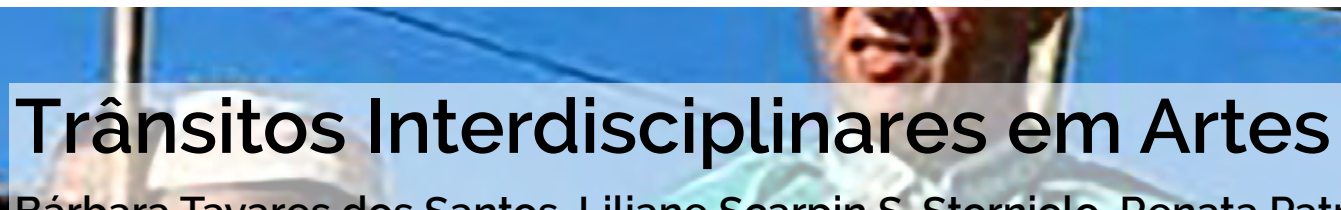 \\ (

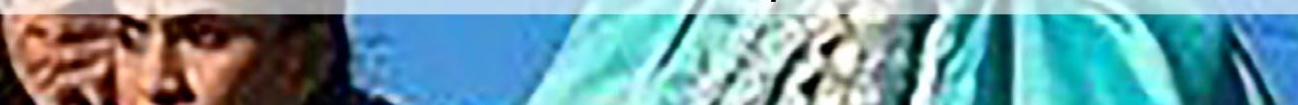

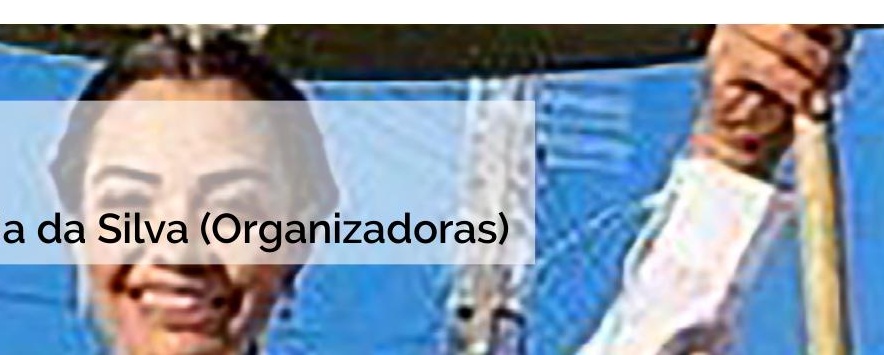

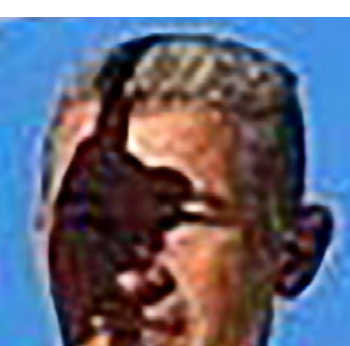

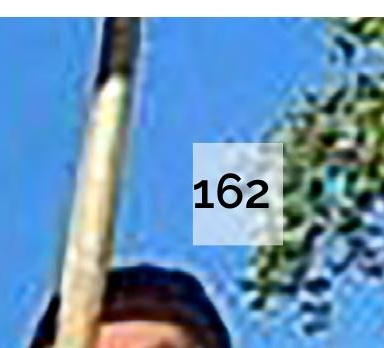


percebem importantes naquele contexto, como se não ajudar os festeiros poderia comprometer a realização da festa. Então é motivo de alegria chegar ao barracão e ser bem acolhido, trabalhar entre amigos, reencontrar afetos, conversar, trocar confidências, gracejar. A festa ali é esse grande encontro, um momento de renovação para as pessoas que nela se envolvem.

A festa é o que fazem dela aqueles que a realizam, ela é revestida dos sentidos que eles the conferem. Ao longo de dois séculos, não obstante o passado de pobreza e decadência, e o presente de fragilidade econômica da região, gerações de carmelitanos se encarregaram de mantê-la viva, sem distanciar- se das tradições que a geraram no seio da irmandade de Nossa Senhora do Rosário dos Pretos do antigo arraial minerador.

Em sua ocorrência os habitantes daquele municipio reafirmam sua importância, seus valores, os traços que os caracterizam, a consciência de que reelaboram há dois séculos algo importante e único que eleva a cidade e a si mesmos, um acontecimento cujo modo particular só eles sabem tecer. Quando a festa termina outra já se encontra no horizonte povoando a expectativa de todos, porque sabem que ela sempre será diferente. não importa quantas vezes aconteça.

\section{Trânsitos Interdisciplinares em Artes}

Bárbara Tavares dos Santos, Liliane Scarpin S. Storniolo, Renata Patrícia da Silva (Organizadoras)

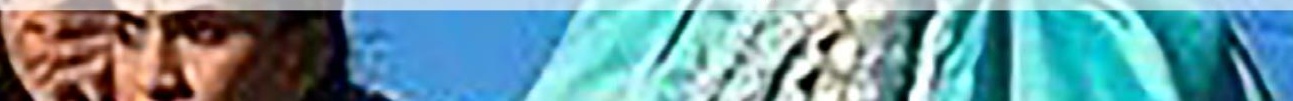




\section{Referências}

ALVES, Nazareth Gomes. Elos perdidos: Monte do Carmo - TO. Palmas, 2009. BAKHTIN, Mikhail. A cultura popular na Idade Média e no Renascimento. São Paulo: Hucitec, 1987.

BRANDÃO, Carlos Rodrigues. A cultura na rua. Campinas, SP: Papirus, 1989

CALLOIS, Roger. O homem e o sagrado. Lisboa: Edições 70, 1988.

CAMPOS, Marta Silva. As festas do Carmo. São Paulo: Gráfica Lider/ COMSAÚDE, 1988.

DUVIGNAUD, Jean. Festas e Civilizações. Fortaleza, Edições Universidade Federal do Ceará \& Rio de Janeiro, Tempo Brasileiro, 1983.

HENRIQUES, Isabel Castro. Os africanos em Portugal. História e Memória Séculos XV-XXI. Lisboa: 2011.

MARAVALL, José Antonio. La Cultura del Barroco. Barcelona: Ariel. 1975.

MESSIAS, Noeci Carvalho. Religiosidade e devoção: as festas do Divino e do Rosário em Monte do Carmo e em Natividade. TO. Tese (Doutorado em História). Goiânia: UFG, 2010.

PRIORE, Mary Del. Festas e utopias no Brasil colonial. São Paulo: Brasiliense, 1994.
TINHORÃO. José Ramos. Festa de negro em devoção de branco: do carnaval na procissão ao teatro no círio. São Paulo: Ed. Unesp, 2012.

SOUZA, Marina de Mello e. Catolicismo negro no Brasil. Santo e minkisi, uma reflexão sobre miscigenação cultural. Revista Afro-Ásia. nº 28, 2002. pp. 125-146.

\section{Referências Orais}

ARAUJO, Caetana Ferreira de - Rainha. Depoimento, jul. 2019.

CHAVES, Magnavita Gomes Alves - Rainha. Pronunciamento, jul. 2019.

LIMEIRA, Edimael de Almeida - Ajudante voluntário. Entrevistas jul. 2017:

out. 2018.

NEGRE, Ana dos Reis Rodrigues - Rainha e Taieira. Entrevista, out. 2017

NERES, Mateus Pereira Gomes- Careta. Entrevista out. 2018

SANTOS, Sebastião Raimundo dos - Congo. Entrevista, out. 2017.

\section{Trânsitos Interdisciplinares em Artes}

Bárbara Tavares dos Santos, Liliane Scarpin S. Storniolo, Renata Patrícia da Silva (Organizadoras) 


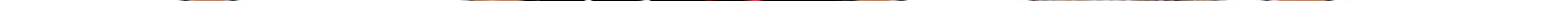




\section{Riso, Fé e Cultura Popular na Boa Vista do Padre João}

Leandro Ferraz

1 Ensinante-arteiro do curso de Licenciatura em Educação Fisica da Universidade Federal do Tocantins, campus de Tocantinópolis. Doutor em Artes pela UNESP-SP, área de concentração em Artes Cênicas; estética e poéticas cênicas. Pesquisador sobre a Cultura Cômica Popular e sobre o Riso na Saúde e na Escola, e-mail: leandrotoc@mail.uft.edu.br.

\section{Trânsitos Interdisciplinares em Artes}

Bárbara Tavares dos Santos, Liliane Scarpin S. Storniolo, Renata Patricia da Silva (Organizadoras) 
Este texto é um fragmento da Tese intitulada "O Ridículo entre o Sagrado e o Profano: a Comicidade e o Riso nos Festejos Religiosos da Boa Vista do Padre João", orientada pelo Professor Doutor Mário Fernando Bolognesi. Por meio da condição de ridículo, ou seja, daquele que promove o riso, dos devotos e dos participantes, analisar quais e como os recursos cômicos constituem o imaginário e a produção de sentidos dos/nos Festejos Religiosos é o objetivo principal deste estudo. Por tanto, neste fragmento proponho uma breve compreensão do que permeia a cultura popular, o riso e a fé, enfim um entendimento sobre o sacro e o profano e a cultura cômica popular.

Para inicio de debate, posso afirmar que "[...] a primeira definição que se pode dar ao sagrado é que ele se opõe ao profano" (ELIADE, 1992, p. 13). No entanto, a etimologia da palavra profano, de acordo com Nascentes (1955), tem origem do latim profanu, que fica diante do templo, de pro diante de e fanu templo, ou seja, o que não pode adentrar em lugar sagrado. Assim, defino neste estudo que o profano está naquilo que não deve, ou não deveria, fazer parte do espaço sagrado.

Sobre a constituição conceitual do sagrado, consequentemente do profano, e suas manifestações, Eliade (1992) diz que: "O homem toma conhecimento do sagrado porque este se manifesta, se mostra como algo absolutamente diferente do profano" (p. 13). Então, os conceitos de sagrado e de profano são interdependentes, assim como o puro e o impuro

Durkheim (2001) traz uma abordagem relacionada às questões de pureza daquilo que pertencem ao sagrado, mas que também podem pertencer ao profano. Assim, não negando a ambivalência do sagrado pelas coisas puras e impuras, o que nos faz pensar que aquilo que está em um pode estar em outro, no caso deste estudo é o riso. "Há duas espécies de sagrado, um fasto e outro nefasto [...] Com o puro, faz-se o impuro, e vice-versa. É na possibilidade dessas transmutações que consiste a ambiguidade do sagrado" (p. 488)

\section{Trânsitos Interdisciplinares em Artes}

Bárbara Tavares dos Santos, Liliane Scarpin S. Storniolo, Renata Patricia da Silva (Organizadoras)
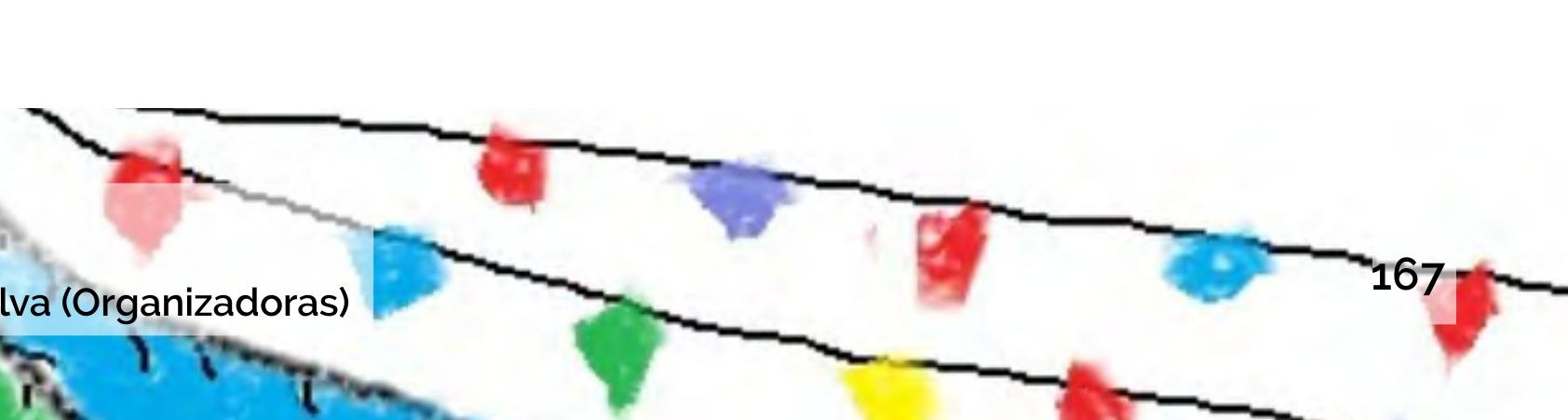
Então, o sagrado e o profano, muitas vezes, confundem-se, em especial sobre a pureza, daquilo que é puro ou impuro aos olhos da doutrina religiosa e das crenças. Dessa forma, posso conciliar o riso como algo que ora pertence ao sagrado, ora pertence ao profano, ora é puro ora impuro.

O riso traz significados aos significantes "Deus" e "Diabo", por meio dos comportamentos, da espiritualidade e da condição de vida de cada sujeito, mesmo que ele esteja imerso em um ambiente sagrado. Pois, "[...] não é sua mudança brusca de atitude que provoca o riso, é o que há de involuntário na mudança, é o mau jeito [...]" (BERGSON, 2004, p. 7):

No mundo criado por Deus, cada ser tinha sua perfeição particular; a essência coincidia com a existência. Não havia nenhuma possibilidade de distanciamento, logo, de rir. Se o riso existe, é em razão do pecado original, que degradou a criação; o homem não coincide mais com ele mesmo. Foi o diabo que produziu essa fissura, pela qual se introduziu o riso. O diabo é ridente, zombador, eternamente distante de si mesmo, para isso foi criado (MINOIS, 2003, p. 630).

A comicidade traz uma nova abertura ao mundo fechado, exclusivo, impermeável das celebrações religiosas. O risivel faz refletir pelo repúdio, mas ao mesmo tempo, faz ressignificar o contexto pelo bem-estar. "Há no riso, sobretudo um movimento de relaxamento" (BERGSON, 2004, p. 144)

O contraste entre as coisas profanas em um contexto sagrado são percebidas nas celebrações pontuais e tradicionais, nas quais há espaço para o riso, a comicidade, a condição de ridículo. Isso pode ser visto nas dramatizações, nas performances ritualisticas e nas narrativas cômicas; muitas na forma de piadas e ironias do cotidiano dos devotos durante as festas. Fischer citado por Freud (1977) diz que: "Um chiste é um juizo lúdico [...]. A liberdade produz chistes e os chistes produzem liberdade. [...] Fazer chistes é simplesmente jogar com as ideias [...]. O chiste é o padre disfarçado

\section{Trânsitos Interdisciplinares em Artes}

Bárbara Tavares dos Santos, Liliane Scarpin S. Storniolo, Renata Patricia da Silva (Organizadoras)
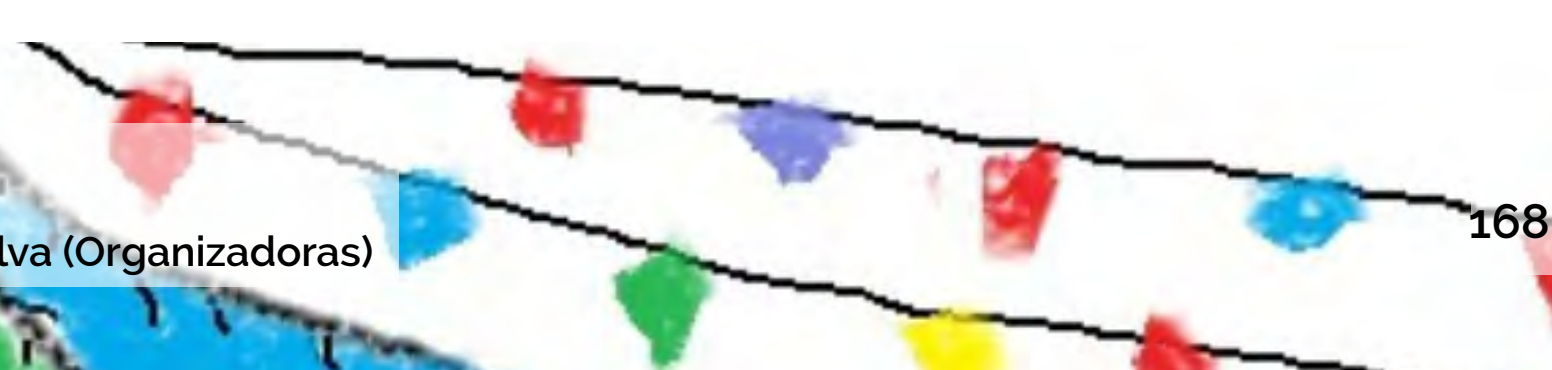
que casa a todo casal" (p. 9). Então, "O riso popular ambivalente expressa uma opinião sobre um mundo em plena evolução no qual estão incluídos os que riem [..." (BAKHTIN, 2010, p.11).

O que nos interessa especialmente são as grosserias blasfematórias dirigidas às divindades e que constituíam um elemento necessário dos cultos cômicos mais antigos. Essas blasfêmias eram ambivalentes: embora degradassem e mortificassem, simultaneamente regeneravam e renovavam. [...] Apesar de sua heterogeneidade original, essas palavras assimilaram a concepção carnavalesca do mundo, modificaram suas antigas funções, adquiriram um tom cômico geral e converteram-se, por assim dizer, nas centelhas da chama única do carnaval, convocada para renovar o mundo (BAKHTIN, 2010, p. 11)

Lembrei-me do Ecce Homo de Nietzsche, no qual diz: "Não sou, por exemplo, um espantalho, um monstro moral - sou antes uma natureza contrária à espécie de homens que, até agora, se veneraram como virtuosos. Aqui só para nós, parece-me que isto ( $\mathrm{sic}$ ) se ajusta precisamente ao meu orgulho. Sou um discípulo do filósofo Dionísio, prefiro ser um sátiro a ser um santo" (2008, p. 7).

Eis o ridículo no meio de nós! Nos ambientes sacros há possibilidades de inserção das coisas profanas, e vice-versa, mas essa inserção só se torna possivel, sem estranhamentos e com marcas profundas, se houver uma leveza nas ações e que deixa o contexto sem descaracterizar as suas proposições. Para isso, o riso entra em cena. "Sem esquecer-vos, tampouco, do bom riso! Essa coroa do ridente, essa coroa de rosas entrelaçadas: a vós, meus irmãos, atiro esta coroa! Eu santifiquei o riso; ó homens superiores, aprendei - a rir!" (NIETZSCHE, 2010, p. 20).

\section{Profano e Sagrado}

Para Eliade (1992), a história das religiões é constituida por manifestações do sagrado em objetos quaisquer, mas que contemplam significações de uma realidade que não pertencem ao nosso mundo, e sim ao mundo espiritual. Uma imagem, uma

\section{Trânsitos Interdisciplinares em Artes}

Bárbara Tavares dos Santos, Liliane Scarpin S. Storniolo, Renata Patricia da Silva (Organizadoras)

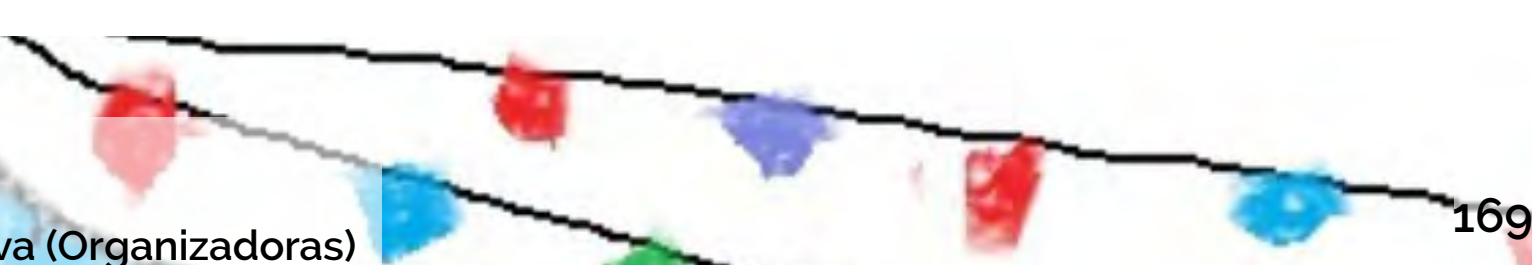


pedra, uma árvore, enfim, um objeto que fora do mundo religioso pode ser apenas um objeto, para o mundo de uma determinada religião traz significados sagrados. Assim, as religiões desde as mais primitivas constituem-se de significados. É no templo que o objeto se ressignifica como sacro, mas fora, tem significado profano.

Em relação à função dos templos religiosos, pode-se dizer que são espaços onde há a transcendência daquilo que é profano. Os templos conferem a ligação daquilo que é sagrado, fazendo com que as pessoas possam fazer encontros com os deuses, pois "[...] é fácil compreender por que a igreja participa de um espaço totalmente diferente daquele das aglomerações humanas que a rodeiam. No interior do recinto sagrado, o mundo profano é transcendido" (ELIADE, 1992, p. 19).

Sobre o espaço religioso e o espaço profano, Eliade (1992) acrescenta que:

A fim de pôr em evidência a não homogeneidade do espaço, tal qual ela é vivida pelo homem religioso, pode-se fazer apelo a qualquer religião. Escolhamos um exemplo ao alcance de todos: uma igreja, numa cidade moderna. Para um crente, essa igreja faz parte de um espaço diferente da rua onde ela se encontra. A porta que se abre para o interior da igreja significa, de fato, uma solução de continuidade. $O$ limiar que separa os dois espaços indica ao mesmo tempo a distância entre os dois modos de ser, profano e religioso. O limiar é ao mesmo tempo o limite, a baliza, a fronteira que distinguem e opõem dois mundos - e o lugar paradoxal onde esses dois mundos se comunicam, onde se pode efetuar a passagem do mundo profano para o mundo sagrado (p. 19).

Mas, não só o espaço, templo, se constitui como sagrado. A objetificação do sagrado também se encontra na constituição dos objetos, em especial aqueles que se referenciam a um santo ou deus, ou algo que remete a eles. Sendo que, "[...] a manifestação do sagrado num objeto qualquer, urna pedra ou uma árvore - e até a hierofania suprema, que é, para um cristão, a encarnação de Deus em Jesus Cristo, não existe solução de continuidade" (ELIADE, 1992. p. 13).

\section{Trânsitos Interdisciplinares em Artes}

Bárbara Tavares dos Santos, Liliane Scarpin S. Storniolo, Renata Patricia da Silva (Organizadoras)

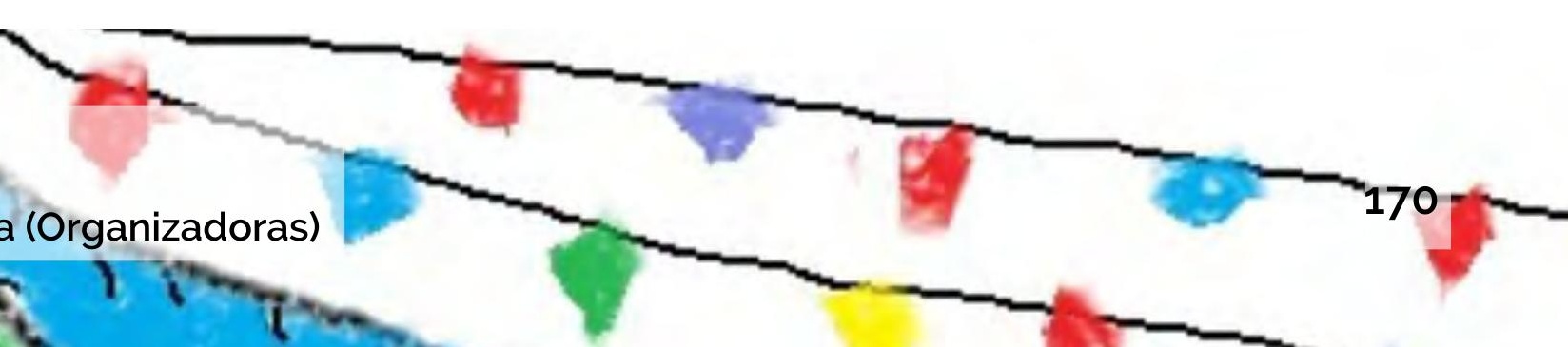


Os atravessamentos das "coisas" profanas ou mundanas, como muitos religiosos assim descrevem, no mundo religioso e das "coisas" religiosas no mundo comum são mais rotineiros do que se pode imaginar; ou se imaginar muitas vezes não se quer aceitar. Para Eliade (1992, p. 98), "[...] o homem a religioso no estado puro é um fenômeno muito raro, mesmo na mais dessacralizada das sociedades modernas. A maioria dos 'sem religião' ainda se comporta religiosamente, embora não esteja consciente do fato".

O profano não necessariamente precisa de um espaço próprio para acontecer, ele se desdobra em qualquer espaço, porém, não é isso que ocorre no sagrado, que necessita de algo fixo para se orientar. Ele precisa marcar o seu lugar. Assim, "[... a revelação de um espaço sagrado permite que se obtenha um "ponto fixo", possibilitando, portanto, a orientação na homogeneidade caótica, a "fundação do mundo", o viver real" (ELIADE, 1992, p. 18).

A experiência profana, ao contrário, mantém a homogeneidade e, portanto, a relatividade do espaço. Já não é possivel nenhuma verdadeira orientação, porque o "ponto fixo" já não goza de um estatuto ontológico único: aparece e desaparece segundo as necessidades diárias. A bem dizer, já não há "Mundo", há apenas fragmentos de um universo fragmentado, massa amorfa de uma infinidade de "lugares" mais ou menos neutros, onde o homem se move. forçado pelas obrigações de toda existência integrada numa sociedade (ELIADE, 1992, p. 18)

Dessa forma, o sagrado constitui-se em um ambiente específico, e tudo que não está nele encontra-se o profano. Toda essa significação simbólica sacra permeia as questões ritualísticas, que também podem fazer-se constituir no profano. É a partir da constituição de ser, de homem religioso, que se confirma o espaço sagrado e se diferencia do espaço profano. Por tanto "[...] o ritual pelo qual o homem constrói um espaço sagrado é eficiente, à medida que ele reproduz a obra dos deuses". [...] então logo nos daremos conta de que o "mundo" todo é, para o homem religioso, um "mundo sagrado" (ELIADE, 1992, p. 21).

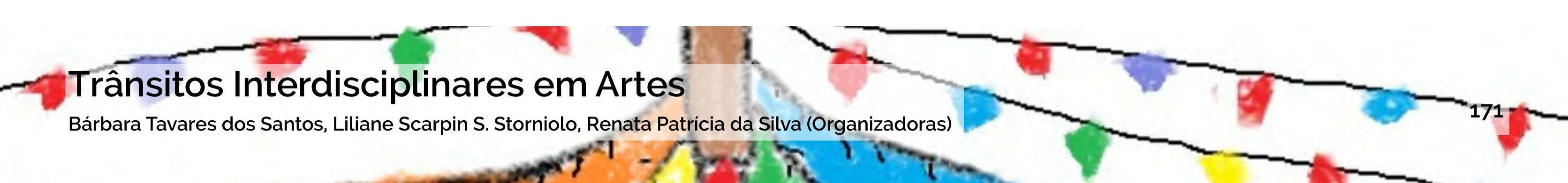


O espaço sagrado, além de se constituir na religiosidade do ser, materializa-se no entendimento de tempo desse ser. Ou seja, vive-se em um mundo profano, apesar de ser religioso, e nos momentos de celebração vive-se um mundo sagrado, alicerçado nos rituais que o funda. Então,

[...] o homem religioso conhece duas espécies de Tempo: profano e sagrado. Uma duração evanescente e uma "sequência de eternidades" periodicamente recuperáveis durante as festas que constituem o calendário sagrado. [...] A festa religiosa é a reatualização de um acontecimento primordial, de uma "história sagrada" cujos atores são os deuses ou os Seres semi-divinos. Ora, a 'história sagrada' está contada nos mitos. Por consequência, os participantes da festa tornam-se contemporâneos dos deuses e dos Seres semi-divinos. Vivem no Tempo primordial santificado pela presença e atividade dos deuses. O calendário sagrado regenera periodicamente o Tempo, porque o faz coincidir com o Tempo da origem, o Tempo "forte" e "puro". A experiência religiosa da festa, quer dizer, a participação no sagrado, permite aos homens viver periodicamente na presença dos deuses (ELIADE, 1992, p. 54-55).

Nesse periodo de consagração, as festividades contemplam a essência espiritual do homem (homem no sentido de espécie humana), que deixa de lado o tempo e o mundo profano quando está imerso no espaço sagrado e no tempo sagrado. O ser humano ressignifica a sua vida como sagrada. É no espaço sacro que o ser humano restabelece toda a sua vida em uma nova perspectiva, em uma dimensão espiritual. Eliade (1992), diz que "É inútil lembrar que não há nenhuma correspondência semelhante ao nivel da experiência profana da Vida" (p. 81). Mesmo que o sujeito não esteja imerso no mundo religioso ele está envolvido culturalmente e socialmente por esse mundo. Porém, os significados e significantes são diferentes, ou seja, "Para o homem a-religioso, todas as experiências vitais - tanto a sexualidade como a alimentação, o trabalho como o jogo - foram dessacralizadas" (p. 81).

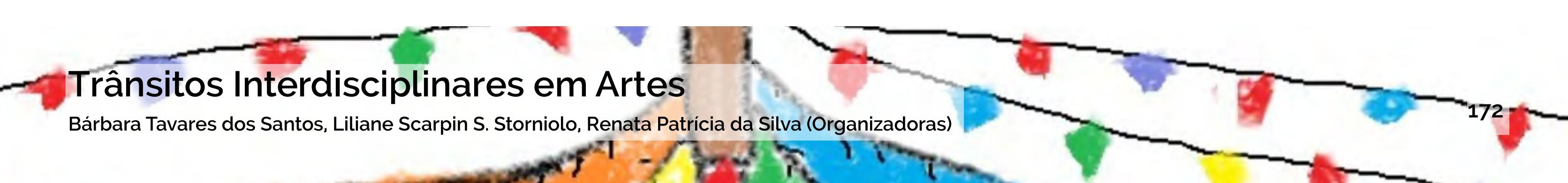


A história do homem, então, pode ser contatada na visão religiosa e do ser religioso, por dois fragmentos de mundo: o sagrado e o profano, ou seja, aquele que está do lado de fora do templo e dos rituais sagrados. Assim.

[...] o sagrado e o profano constituem duas modalidades de ser no Mundo, duas situações existenciais assumidas pelo homem ao longo da sua história. Esses modos de ser no Mundo não interessam unicamente à história das religiões ou à sociologia, não constituem apenas o objeto de estudos históricos, sociológicos, etnológicos. Em última instância, os modos de ser sagrado e profano dependem das diferentes posições que o homem conquistou no Cosmos e. consequentemente, interessam não só ao filósofo, mas também a todo investigador desejoso de conhecer as dimensões possiveis da existência humana (ELIADE, 1992. p. 14-15).

A concepção desses dois mundos: sagrado e profano fazem parte da constituição do próprio homem e sua identidade.
Não se pode pertencer a um desses mundos sem ao menos ter significado um pelo outro anteriormente. É a negação de um que se constitui o lugar no outro. "O sagrado e o profano foram sempre e em toda a parte concebidos pelo espírito humano como gêneros separados, como dois mundos entre os quais nada há de comum" (DURKHEIM, 2001, p. 42)

Para Durkheim (2001), O sagrado e o profano são dois mundos que não são concebidos separadamente, mas tomamse formas hostis e de rivalidade. Sendo que, para pertencer plenamente a um desses mundos, antes é preciso negar e renunciar o outro. Assim, para levar uma vida religiosa, o sujeito precisa abdicar das questões profanas, e vice-versa.

Todavia, há certa dificuldade de distanciamento de um mundo para o outro, do sagrado para profano e do profano para o sagrado. Os rituais, os mitos e os comportamentos continuam significando o sujeito, mesmo que ele negue a religião. Pois, só o fato de negar não o desloca do mundo sagrado para o profano. A cultura continua ainda impregnada e significando muitos símbolos

\section{Trânsitos Interdisciplinares em Artes}

Bárbara Tavares dos Santos, Liliane Scarpin S. Storniolo, Renata Patricia da Silva (Organizadoras)
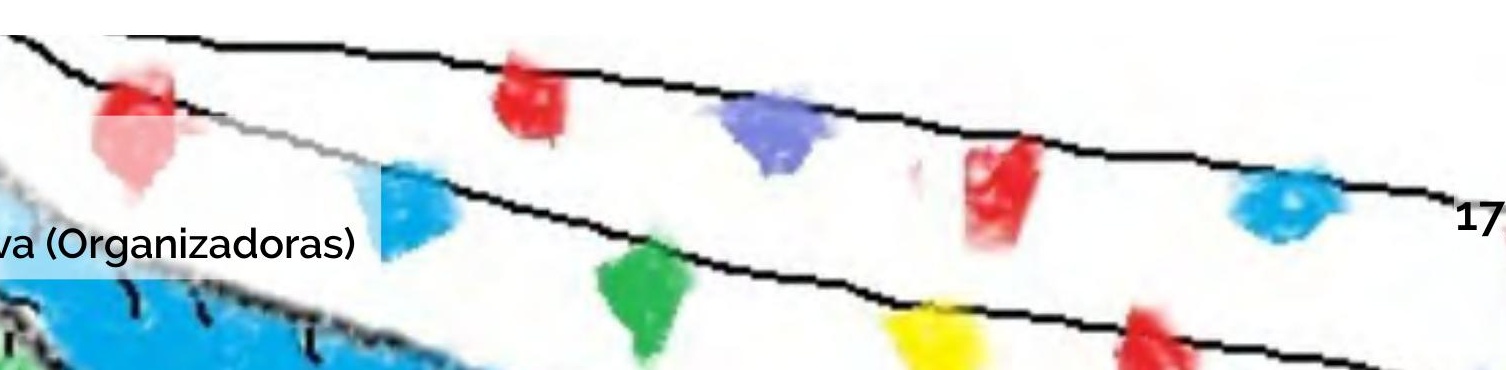
na sua vida, por mais que esteja fora do templo. A coletividade tem papel marcante nessa constituição. "O homem a-religioso no estado puro é um fenômeno muito raro, mesmo na mais dessacralizada das sociedades modernas" (ELIADE, 1992, p. 98)

De acordo com Eliade (1992), os sujeitos "sem religião", mesmo que sem intenção comportam-se religiosamente. Os rituais e as tradições com base religiosa e de celebração fazem parte da sua vida, pois a constituição cultural e social da sociedade em que está inserido traz raízes nos costumes e nos símbolos das religiões predominantes

Essa separação de mundos, muitas vezes, dificulta o próprio homem a entender o mundo real. E em relação às artes não é diferente. A arte sacra, ou aquilo que está relacionado a ela, sofre um significado e um direcionamento diferente de valores morais para um religioso do que a que está separada em uma conotação profana. De acordo com Barroso (2016), a separação proposta pela modernidade entre o sagrado e o profano, o cultural e o natural, "[...] fragmentou a arte em diferentes linguagens, num processo esquizofrênico de retalhamento do universo" (BARROSO, 2016, p. 78).

Assim, também, podem-se conjugar esses valores morais atribuidos à religião como advindos da fé, da devoção, que sustenta a formação de significados do espaço sagrado. Por meio da religiosidade, forjada na devoção aos santos, como é o caso do catolicismo, os rituais de piedade marcam o lugar de cada devoto no espaço sagrado. Tanto que.

"[...] se por um lado a devoção era considerada pela "elite católica" como sinônimo de ignorância religiosa, por outro ela tem ajudado a manter acesa a chama da esperança diante das realidades de crise e sofrimento" (PEREIRA, 2003, p. 71).

Dentro desse contexto, de mundos sagrado e profano, há diversas possibilidades de registrar a fé, de devoção. Alguns usam a repetição de orações, denominadas de rezas pelos católicos, outros usam da autoflagelação, enquanto isso, muitos utilizam de recursos

\section{Trânsitos Interdisciplinares em Artes}

Bárbara Tavares dos Santos, Liliane Scarpin S. Storniolo, Renata Patricia da Silva (Organizadoras) 
bastante controversos, como é caso da embriaguez. Parece que o ato de beber, ou o de se embriagar, faz parte de um contexto ritual, o que para alguns é visto como profano, para outros é tido como sagrado, ou pelo menos um caminho para se chegar até o sacro. Então, Valeri (1994) diz que:

[...] o que é especificamente ritual, ou pelo menos é um dos seus aspectos fundamentais, não passa de uma variante particular numa família de fenômenos em que cabem também o jogo e a arte (p. 354). [...] o que faz passar uma ação da esfera do rito à da arte ou do jogo, e vice-versa, não são tanto as suas propriedades intrínsecas como os efeitos variáveis que elas possuem em contextos diversos e sobre espectadores diversos (p. 356).

Além das bebidas nas celebrações religiosas, as comidas fazem parte do que há mais festivo no espaço sagrado. Os banquetes trazem o prazer do comer e beber, além das danças e do mundo profano como prática de festividade. O riso também ganha liberdade de se apresentar, pois em um banquete não pode faltar os prazeres da carne. "Come-se ritualmente, e a alimentação é diversamente valorizada segundo as diferentes religiões e culturas: os alimentos são considerados sagrados, ou um dom da divindade. ou uma oferenda aos deuses do corpo [..." (ELIADE, 1992, p. 82).

Para a consciência moderna, um ato fisiológico - a alimentação, a sexualidade etc. - não é, em suma, mais do que um fenômeno orgânico, qualquer que seja o número de tabus que ainda o envolva (que impõe, por exemplo, certas regras para "comer convenientemente" ou que interdiz um comportamento sexual que a moral social reprova). Mas para o "primitivo" um tal ato nunca é simplesmente fisiológico; é, ou pode tornar-se, um "sacramento", quer dizer, uma comunhão com o sagrado (ELIADE, 1992, p. 14).

Essas vivências de consagração entre as questões fisiológicas e o sagrado, ainda perduram para alguns povos e crenças. A ritualização faz parte do homem enquanto ser social, desde os tempos remotos. Assim, as crendices populares marcaram

\section{Trânsitos Interdisciplinares em Artes}

Bárbara Tavares dos Santos, Liliane Scarpin S. Storniolo, Renata Patricia da Silva (Organizadoras)

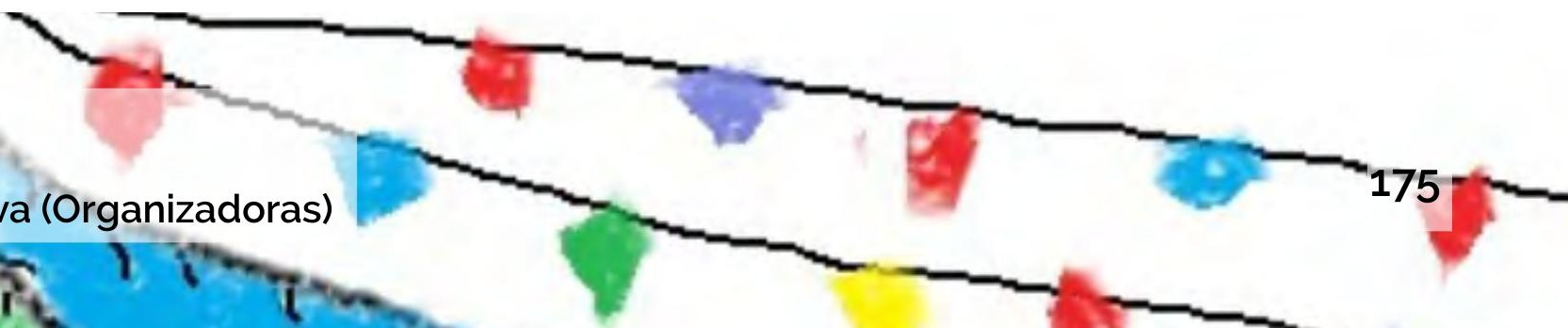


e marcam território nos pensamentos e no cotidiano de diferentes culturas. E traz a devoção como um instrumento de manutenção e conhecimento vulgar sobre os rituais, os mitos e a fé. "É provável que, num passado muito longínquo, todos os órgãos e experiências fisiológicas do homem, bem como todos os seus gestos, tivessem um significado religioso" (ELIADE, 1992, p. 81).

Dentre essa diversificação ritualística da devoção está a procissão, o processo ritual mais comum entre os devotos. Podese afirmar que em todas as celebrações aos santos católicos há procissão dos fiéis. Este tipo de ritual traz um significado de transcender a fé do devoto ao mundo exterior, ou talvez, seja o sagrado ampliando o seu espaço e constituindo os lugares. Yi Fu Tuan, sobre "Espaço e lugar", diz que estes termos indicam experiências comuns, sendo que lugar é tido como segurança e espaço a liberdade. Neste sentido, o indivíduo se liga ao lugar e deseja o espaço. Lugar, então, é o centro que se atribui valores e onde se vive (no caso da existência) e se vivencia (a experiência).
Assim, a medida que conhecemos e construimos valores no espaço, o transformamos em lugar.

Juntamente com a procissão, a peregrinação ganha sentido nessa ampliação do sagrado no mundo exterior aos templos.

Peregrinação e Procissão aparecem como similares, pois detêm o mesmo significado simbólico que é o de caminhar. no entanto o primeiro denota uma caminhada mais distante. ida a um lugar sagrado, muitas vezes revestido de dor. penitência, o segundo já se apresenta como um sentido de cortejo, geralmente possui um santo patrono e se configura com um caminhar mais curto em relação a distância, se dá geralmente em torno/para um templo, ou pela cidade. porém ambos representam uma ida, uma caminhada que busca, seja pela devoção seja pela penitência, o diálogo com o transcendente (OLIVEIRA, 2012, p. 17).

A transcendência é, então, o principal foco da religiosidade, fazendo com que as práticas ritualísticas. A devoção nas procissões

\section{Trânsitos Interdisciplinares em Artes}

Bárbara Tavares dos Santos, Liliane Scarpin S. Storniolo, Renata Patricia da Silva (Organizadoras)
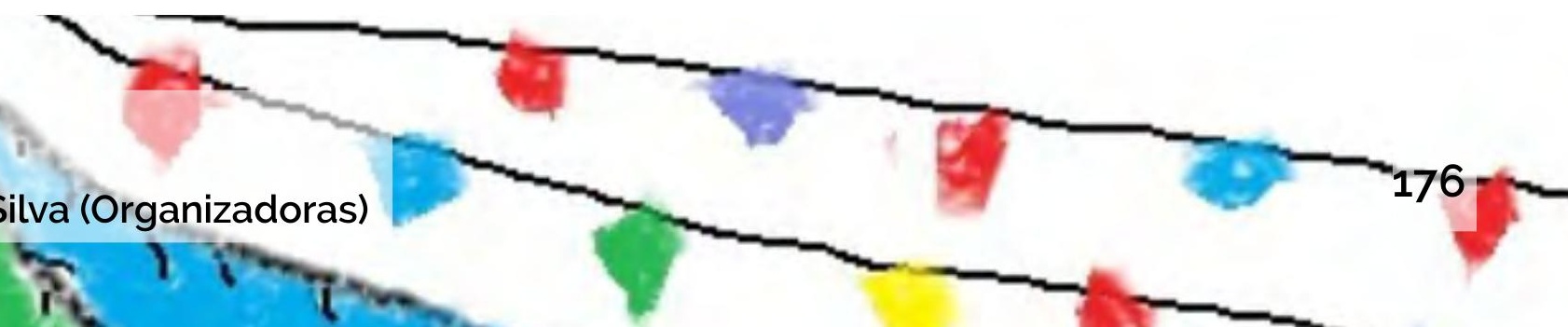
e andanças e nos festejos de celebração dos santos católicos, é como se fosse o caminho até o sagrado em sua plenitude, se é que isso seria possivel. Porém, o que é visto por muitos, em especial, os que não estão envolvidos no processo, como algo sem valor.

Para Pereira (2003), o termo devoção teve, ao longo do tempo e da história, uma conotação pejorativa, especialmente no periodo colonial cristão. Devido a questões de poder da igreja, havia uma intenção de desqualificar as manifestações de cunho religioso que estavam no meio popular. Assim, mantinham-se o controle dos fiéis e suas manifestações contra a igreja, tanto que houve uma tentativa de substituir o termo devoção por "religiosidade popular".

Nesse contexto de devoção, pode-se encontrar, algumas vezes escondidos, o diálogo entre o sagrado e profano. O que para alguns é sagrado para outros é profano e, dependendo do contexto, algo pode ser sacro ou mundano. O ritual pagão da pirotecnia, que é muito utilizado em festas e celebrações religiosas de origem cristã, é um exemplo disso. Bem como as máscaras, que trazem uma conotação carnavalesca aos festejos, e que deixam no espaço sagrado a possibilidade de expurgo ou catarse.

A máscara o ajudava a ter a liberdade necessária ao fustigamento das personagens que figuravam pessoas e entidades pretensiosas, pela chalaça, pela troça, pela maledicência e pelo sarcasmo. Protagonizavam a tradição oral das cantigas de escárnio e maldizer, numa performance voltada para o riso (BARROSO, 2016, p. 67)

Durante os festejos que celebram os santos católicos, encontra-se uma junção cultural, inclusive de rituais religiosos de outras religiões e/ou manifestações espirituais e de fé. O que pode ser conferido nas ofertas e oferendas, e nos momentos das danças com os batuques e ritmos musicais que contemplam uma cultura específica. "Os batuques são o movimento da ancestralidade, dança de resistência, de regatear, de brincar, de seduzir e de rememorar" (SILVA; ROSA, 2017, p. 270). Dessa forma, recriam e ressignificam mundos por meio de seus "atores sociais" e, por suas visões de

\section{Trânsitos Interdisciplinares em Artes}

Bárbara Tavares dos Santos, Liliane Scarpin S. Storniolo, Renata Patricia da Silva (Organizadoras) 
mundos, da arte e da cultura trazem o envolvimento ao universo da magia e do encantamento. Nesse sentido, estabelecem um limiar de relação entre o sacro e o profano, ou seja, aquilo que está fora e dentro do templo. "Tal relação se manifesta no respeito aos tambores, ancestrais e outras entidades espirituais" (p. 252).

O sagrado e o profano, por fim, adentram nas festas religiosas e continuam o seu diálogo. Nessas festas podemse conferir os limites do profano no espaço sagrado. As festas religiosas, apesar de serem sagradas trazem possibilidades de afrontarem-se por situações profanas.

\section{Cultura Popular e as Festas dos Santos Católicos na Boa Vista do Padre João}

Neste estudo versarei apenas sobre as festas religiosas de celebração católica que fazem parte da programação anual da Diocese de Boa Vista do Padre João, que foram visitadas entre os anos de 2016 a 2018. Esses festejos promovem a devoção aos santos intercessores da igreja e mantém a fé dos devotos por meio da aproximação entre o espaço sagrado e a cultura popular.

Segundo Azzi (1994, p. 296), "[...] a devoção ao Santo constitui para o fiel uma garantia do auxilio celeste para as suas necessidades. A lealdade ao Santo manifesta-se, sobretudo no exato cumprimento das promessas feitas". A devoção, então, perpassa a intercessão dos santos diante do Deus reverenciado pela igreja, pois,

[...] a vida dos santos são exemplos a serem seguidos. Pedir a sua intercessão é estar em comunhão com ele na mesma fé. [...] deve-se também valorizar as manifestações religiosas do povo expressas, no catolicismo popular. Pedir a intercessão de um santo é juntar-se a ele em oração a Jesus Cristo (MESQUITA, 2015, p. 170).

As festas religiosas de culto aos santos fazem parte da "[...] cultura do interior do Brasil, marcada por costumes locais, tais

\section{Trânsitos Interdisciplinares em Artes}

Bárbara Tavares dos Santos, Liliane Scarpin S. Storniolo, Renata Patricia da Silva (Organizadoras) 
como as chamadas 'festas de santo'" (SANTOS; DUARTE, 2010, p.1). Esses festejos consagram a vida religiosa dos santos católicos e trazem um simbolismo da fé cristã por meio da intercessão divina. "Temos como hipóteses que essas festas compõem e recompõem as representações que homens e mulheres, habitantes do meio rural e de pequenas cidades do interior do país, possuem sobre seus santos e santas de devoção" (p. 2).

O calendário dos Festejos Religiosos da Paróquia Nossa Senhora da Consolação, da Boa Vista do Padre João, tem como marco inicial e final do seu ciclo o Festejo em comemoração aos Santos Reis, que inicia em dezembro e segue até janeiro do ano seguinte. No mês de janeiro acontece, também, a celebração de São Sebastião: em fevereiro São Lázaro: março contempla São José e maio Nossa Senhora de Fátima, Dom Orione, Santa Rita de Cássia e a celebração a Santíssima Trindade: Santo Antônio, São João e Sagrado coração de Jesus são os festejos de junho; em julho é festejada Nossa Santa' Anna e agosto Nossa Senhora da Consolação e São Raimundo Nonato; em setembro celebra-se São
Vitor, finalizando o mês com São Francisco de Assis e Nossa Senhora do Rosário; outubro é mês de celebrar Nossa Senhora Aparecida e em novembro Cristo Rei; Nossa Senhora da Conceição e Santa Luzia fecham as comemorações religiosas anuais no mês de dezembro, além dos Santos Reis que finalizam e iniciam um novo ciclo.

O mergulho pelos festejos religiosos locais faz com que eu me lembre da obra de Bakhtin. A cultura popular na Idade Média e no Renascimento: o contexto de François Rebelais, na qual o autor trata da cultura cômica popular, no periodo entre Idade Média e o Renascimento. Bakhtin apresenta um olhar sobre o espaço público, a praça pública, ocupados pela população com regimes autoritários e em uma vida de rígida religiosidade, mas que nos momentos carnavalescos, festivos, exploram o riso, o dito "tempo alegre". Pois,

[...] a festa é também fato político, religioso ou simbólico. Os jogos, as danças e as músicas que a rechearam não só significam descanso, prazeres e alegria durante sua realização; eles têm simultaneamente importante função social: permitem às crenças, aos jovens, aos espectadores

\section{Trânsitos Interdisciplinares em Artes}

Bárbara Tavares dos Santos, Liliane Scarpin S. Storniolo, Renata Patricia da Silva (Organizadoras)

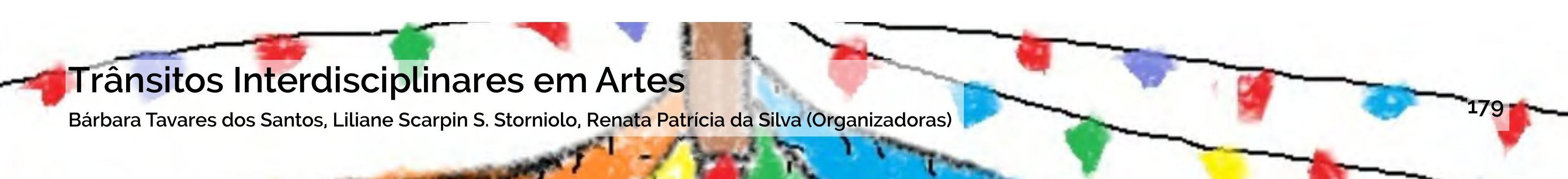


e atores da festa introjetar valores e normas da vida coletiva, partilhar sentimentos coletivos e conhecimentos comunitários (DEL PRIORE, 2000, p.10)

Essas festas de sentido barroco trazem em suas programações as seguintes partes: a) o culto, que pode ser conduzido por um sacerdote ou por alguém da comunidade. Assim seguem as diretrizes de uma missa padrão da igreja católica; b) a quermesse, ou como denominam na região, leilões. As quermesses ou leilões são compostos por ofertas de comidas e demais produtos oferecidos por moradores locais para que sejam vendidos/leiloados, e a arrecadação serve para fazer as melhorias nas dependências das igrejas; c) as barracas de alimentos, bebidas, brechós e d) as festas dançantes, dependendo da comunidade e do santo a ser celebrado.

Triadó (1991) citado por Oliveira (1999, p. 24) diz que "Barroco é o superlativo do extravagante, o excesso do ridículo". Então, por mais simples que as igrejas se apresentem, em momentos de festividades o caráter extravagante prevalece nas ornamentações.

Percebe-se o caráter espetacular nas festas religiosas, principalmente, nesse caso, sobre a dramatização e as encenações. E não exclusivamente na programação, mas, também, no cotidiano. Sendo que,

[...] a arte, a religião, a política e o cotidiano possuem aspectos espetaculares (inserindo-se assim no campo de estudos da etnocenologia), mas que não são áreas de conhecimento indistintas. O que as articula, em sua distinção conceitual e funcional, é justamente uma relativa indistinção corporal comportamental, enquanto interação coletiva necessariamente incorporada nas pessoas participantes, ou o que se poderia denominar de comportamentos espetaculares (mais ou menos) organizados e objeto desta almejada cenologia geral, hoje denominada temporariamente etnocenologia (BIÃO, 1999, p. 18).

\section{Trânsitos Interdisciplinares em Artes}

Bárbara Tavares dos Santos, Liliane Scarpin S. Storniolo, Renata Patricia da Silva (Organizadoras) 
O ambiente e os comportamentos humanos e coletivos nos festejos religiosos são mais do que rotinas sociais, são movimentos espetaculares que, deveriam ser lidos e apreciados. Então, essas rotinas sociais das celebrações religiosas "podem se constituir em eventos, consideráveis, a depender do ponto de vista de um espectador, como espetaculares, a partir de uma espécie de atitude de estranhamento, que os tornaria extraordinários" (BIÃO, 2007, p. 28).

Assim, me embaso na etnocenologia para complementar a análise das observações e das narrativas. Pois, o que seria espetacular? Espetacular é "Uma forma de ser, de se comportar, de se movimentar, de agir no espaço, de se emocionar, de falar. de cantar e de se enfeitar. Uma forma distinta das ações banais do cotidiano" (PRADIER, 1999, p. 24).

Além disso, Pradier (1999) diz que "Existem tantas práticas espetaculares no mundo que se pode razoavelmente supor que o espetacular, tanto quanto a língua e talvez a religião, sejam traços específicos da espécie humana (p. 28)". Nesse sentido.
As expressões práticas espetaculares e comportamentos humanos espetaculares organizados servem para dar conta desse conjunto de fenômenos sociais nos quais está o teatro, nos quais está a performance, mas nos quais também estão o ritual religioso, a procissão, as festas públicas, as competições esportivas ou as manifestações políticas. Esses grandes fenômenos sociais que reúnem coletividades e que interferem na vida cotidiana promovem uma espécie de respiração social (BIÃO, 2009, p. 128).

Essas práticas expressivas espetaculares envolvidas nos festejos religiosos da igreja católica trazem na herança cultural da formação do povo brasileiro, não só características religiosas, mas também, de todo fenômeno social imbricado nos comportamentos. Nessas festas, o espaço religioso recebe o encontro do profano a partir da cultura popular e a devoção, como por exemplo, a Festa do Divino Espírito Santo.

De acordo com relatos do IPHAN (Instituto do Patrimônio Histórico e Artístico Nacional) (2009), a festa é a forma de agradece

\section{Trânsitos Interdisciplinares em Artes}

Bárbara Tavares dos Santos, Liliane Scarpin S. Storniolo, Renata Patricia da Silva (Organizadoras) 
ao Divino e é a certeza de receber suas bênçãos. Existem várias formas de contribuir nessa festa, como Imperador, como cozinheiro, como folião ou como cavaleiro. A festa é feita como um momento solidário, o qual tem o objetivo de redistribuir e compartilhar. independente da função e atuação, todos os participantes ficam envolvidos, pois constituem o seu lugar no festejo. "É a partir deste lugar que se realiza a densa troca simbólica entre o Divino Espírito Santo e seus devotos" (p. 13).

E foi na Festa do Divino Espírito Santo que me encontrei como pesquisador e com o objeto da pesquisa. "Foi o Divino" como diria uma amiga, que me deu ideias para formatar o caminho para a tese. A celebração do Divino traz aos ares sagrados o profano com requintes de comicidade. Assim é o Festejo do Divino,

[...] que é uma festa religiosa, de herança portuguesa, que celebra o Pentecostes. No Maranhão, a festa tem um ritual próprio, no qual uma parte extremamente importante é a presença das caixeiras, que recebem esse nome devido ao instrumento que tocam, chamado caixa, que é um tambor de dias peles, tocado com baquetas. As caixeiras conhecem o andamento desse rito. Como tradicionalmente a festa durava muitos dias, havia momentos de intervalo, ou mesmo após o encerramento da festa, em que as caixeiras se reuniam para toques mais profanos, ou seja, para cantar. dançar e brincar (OLIVEIRA, 2006, p. 84).

Além da Festa do Divino Espírito Santo, a igreja católica promove a celebração de outras entidades religiosas, os santos. Muitos festejos celebram os Santos e as Santas, que têm em suas figuras o simbolismo de intercessão dos devotos. O que é o caso da Festividade em Honra a Santa'Anna, a avó de Jesus. A celebração acontece na segunda quinzena do mês de julho.

A segunda santa mais cultuada no Brasil colônia é Anna, mãe da Virgem Maria. A mãe de Cristo - santa de predileção da Igreja da Contra-Reforma [...] O culto da Virgem Maria tornou-se importante no Ocidente a partir do século XII, com a valorização da genealogia e da infância de Cristo [...] O primeiro episódio da vida de Maria foi sua

\section{Trânsitos Interdisciplinares em Artes}

Bárbara Tavares dos Santos, Liliane Scarpin S. Storniolo, Renata Patricia da Silva (Organizadoras) 
concepção no ventre de sua mãe, Sant'Anna. Uma festa conhecida como a "Concepção de Anna" era celebrada em Constantinopla desde meados do século VIII e no Ocidente um século mais tarde (SOUZA, 2002, p. 232, 233).

A celebração de Santa Anna acontece no mês de julho de cada ano, em especial fixada a data de 26 de julho pelo Papa Gregório XIII. Segundo a crença popular, é nesse dia que se comemora o Dia dos avós, pois o Papa Paulo VI juntou a Festa de Santa' Anna com a Festa de São Joaquim, avós de Cristo, fundando uma nova data de comemoração.

Outro santo em destaque nesse estudo é Santo Antônio, comemorado na primeira quinzena do mês de junho. De acordo Castro (1987). Santo Antônio é um santo de origem portuguesa, foi de família nobre. Foi da Ordem Franciscana e lutava pelos mais oprimidos. Viveu no fim do século XII e início do XIII, seguia as regras de Santo Agostinho e era considerado um dos "Doutores da igreja". Tem fama de ser o santo casamenteiro, sendo que, sua celebração é realizada "[...] em torno de fogueiras, por entre berreiros de cantigas, em gastronômicas comilanças, em torneios beberrões, a tiros de garrucha, estrugir de foguetório, excursões aos rios e cisternas - em romarias casamenteiras" (p. 61).

O mês de junho é um período carregado de festividades religiosas, tanto que muitas saíram do contexto religioso e tomaram gosto pela diversão da cultura popular, como é o caso da Festa de São João. Essas festividades conhecidas popularmente como Festas Juninas trazem a contemplação das coisas profanas no espaço sagrado e, o contexto sagrado e da religiosidade para fora do templo.

Se pesquisarmos a origem dessas festividades. perceberemos que elas remontam a um tempo muito antigo, anterior ao surgimento da era cristã. De acordo com o livro O ramo de ouro, de sir James George Frazer, o mês de junho, tempo do solstício de verão (no dia 21 ou 22 de junho o Sol, ao meio-dia, atinge seu ponto mais alto no céu; esse é o dia mais longo e a noite mais curta do ano) no Hemisfério Norte, era a época do ano em que diversos povos celtas, bretões, bascos, sardenhos, egípcios, persas, sírios, sumérios - faziam rituais de invocação de fertilidade para

\section{Trânsitos Interdisciplinares em Artes}

Bárbara Tavares dos Santos, Liliane Scarpin S. Storniolo, Renata Patricia da Silva (Organizadoras) 
estimular o crescimento da vegetação, promover a fartura nas colheitas e trazer chuvas (RANGEL, 2008, p. 15).

Segundo Côrtes (2000), o ciclo das festas juninas se estende desde as celebrações a Santo Antônio no dia 13 de junho, passando pelo Festejo de São José e finalizando com a Festa de São João no dia 24 e São Pedro no dia 29 desse mês. De acordo com Nóbrega (2010), o festejo de São João Batista se destaca como a principal festa popular e manifestação em homenagem a um santo. Essa celebração tem origem rural e simboliza o periodo de mudança climática e as colheitas do milho e do feijão. Em relação à devoção, este festejo representa a purificação, pois o santo em questão é símbolo de amor, alegria, ludicidade e erotismo. Nessa celebração.

As fogueiras, símbolo máximo da comemoração, estão relacionadas às tradicionais festas pagãs existentes na Europa antes da chegada do cristianismo, realizadas em homenagem aos deuses da fertilidade, em que se comemoravam as boas colheitas e o fim do inverno. [...] A adoração a são João era tradicional na Península Ibérica e foi, portanto, trazida ao Brasil pelos jesuitas. [...] A festa chegou ao Brasil, já carregada de elementos sacros e pagãos. A fogueira foi, então, relacionada ao lendário fogo de são João (CÔRTES, 2000, p. 23).

A programação do ano festivo da igreja católica inicia e termina o seu ciclo pela celebração aos Santos Reis, ou Reis Magos, também conhecida como Folia de Reis, coincidindo com o nascimento de Jesus, o representante central dessa religião. Porém, "[...] não há dados confiáveis no que tange a serem os magos 'reis' e muito menos 'santos', títulos que a religiosidade popular thes conferiu [...]" (GALVÃO, 2002, p. 19). Para Pergo (2012):

[...] a tradição da "Folia de Reis" teria chegado ao Brasil por intermédio dos portugueses no período da colonização, uma vez que, essa manifestação cultural era realizada por toda a Península Ibérica sendo comum a doação e recebimento de presentes a partir da entoação de cantos e danças nas residências. Nessa linha de argumentação,

\section{Trânsitos Interdisciplinares em Artes}

Bárbara Tavares dos Santos, Liliane Scarpin S. Storniolo, Renata Patricia da Silva (Organizadoras) 
a Folia de Reis teria surgido no Brasil no século XVI, por volta do ano de 1534, por meio dos Jesuítas, como crença divina para catequizar os índios e posteriormente os negros escravos. Dessa forma, a Folia de Reis brasileira passou a ser composta pelas manifestações culturais de diversas etnias e povos, com variações regionais, seja quanto ao estilo, ao ritmo e ao som, entretanto, mantendo a mesma crença e devoção ao Menino Jesus, a São José, à Virgem Maria e aos Reis Magos (p. 1).

No mês de dezembro celebra-se a Imaculada Conceição ou Nossa senhora da Conceição. De acordo com Boyer (2000, p. 13), "A imaginação dos crentes tem outros poderes criadores, segundo as épocas, segundo os países e segundo as necessidades, eles reinventaram constantemente a imagem da personagem virtual que é a Virgem Maria". Para Becker (1999), a imagem da Imaculada Conceição com mãos unidas, remete a Idade Média e indica que a santa está em um gesto de oração, cativando assim, os devotos a fazer o mesmo
Não tenho a intenção de associar o catolicismo com as religiões de matriz africanas, pois o foco deste estudo é o riso, porém. é preciso destacar que em muitas celebrações há a junção cultural religiosa, mesmo que implícita. De acordo com Leite (2003), de um lado Nossa Senhora da Conceição aclamada por cânticos católicos, fogos e devoção em barcos enfeitados e de outros, Iemanjá conduzida em embarcações ornamentadas e flores lançadas nas águas em ritualização das religiões afro-brasileiras. Assim, pode-se fazer uma inter-relação entre as duas divindades religiosas, o que está imbricado na junção cultural religiosa do brasileiro.

Destaco esse festejo, pois naquele espaço de celebração a Imaculada Conceição foi, ou ainda é um local de encontros de celebração de uma religião afro-brasileira. O que marca a região e o seu encontro religioso e de diversidade devocional, mas parece não haver perturbações profundas quanto a isso. Apenas vive-se a religiosidade e a espiritualidade. Assim com essa divindade, outras tantas são lidas em outras religiões e/ou manifestações religiosas com outras denominações.

\section{Trânsitos Interdisciplinares em Artes}

Bárbara Tavares dos Santos, Liliane Scarpin S. Storniolo, Renata Patricia da Silva (Organizadoras)
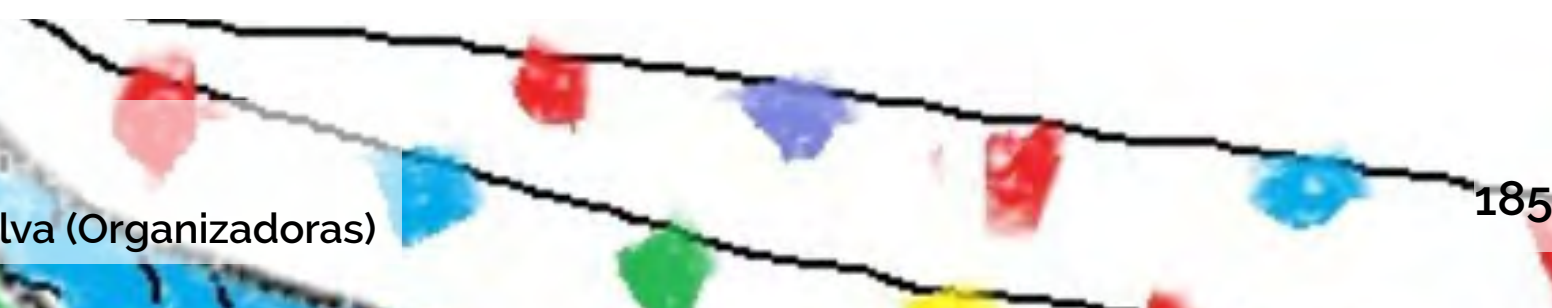
Outro icone religioso e que faz referência a Maria, mãe de Jesus, está na celebração do título de Nossa Senhora da Consolação. Essa titulação segue como a padroeira da cidade de Boa Vista do Padre João e é celebrada no mês de agosto. Esse título a Nossa Senhora remete a Maria como consoladora dos aflitos e sua devoção foi iniciada por Santa Mônica.

Por fim, a festividade em Honra a São Francisco de Assis, que é celebrada entre os meses de setembro e outubro. "Meio religioso, meio leigo, nas cidades em pleno desenvolvimento, nas estradas e no retiro solitário, no florescimento da civilização urbana combinado com uma nova prática de pobreza, da humildade e da palavra, à margem da Igreja" (2001, p.9), assim o historiador Le Goff define Francisco de Assis, um jovem italiano que viveu entre os séculos XII e XIII e que abdicou da vida farta como filho de mercador e seguiu os votos de pobreza, apresentando uma visão diferente sobre a humanidade. E continua,
Francisco alcança os últimos gestos da imitação de Cristo dos quais, antecipadamente, recebeu, através dos estigmas, a marca final. A 2 de outubro, reproduz a ceia. Benze e parte o pão e o distribui a seus irmãos. No dia seguinte, 3 de outubro de 1226, recita o Cântico do Irmão Sol, lê a Paixão no Evangelho de João e pede que o depositem na terra sobre um cilício coberto de cinzas. Nesse momento um dos irmãos vê de repente sua alma, como uma estrela, subir direto ao céu. Tinha quarenta e cinco ou quarenta e seis anos (LE GOFF, 2001, p. 91).

Essas celebrações religiosas da igreja católica têm a intenção de promover a devoção nas pessoas que fizeram parte da vida de Jesus, e aquelas que, depois da sua passagem. continuaram propondo e disseminando as suas propostas, tidas como ensinamentos pelos fiéis. A referida igreja mantém em seu calendário festivo a adoração aos santos e suas intervenções diante do sagrado, pois é por meio dos santos que os devotos fortalecem a sua fé. De acordo com a doutrina da igreja, esse fato acontece

\section{Trânsitos Interdisciplinares em Artes}

Bárbara Tavares dos Santos, Liliane Scarpin S. Storniolo, Renata Patricia da Silva (Organizadoras) 
[...] porque os santos estão no meio de nós, pertencem à nossa família e nós a deles. Como Igreja a caminho. que hoje dá os primeiros passos para o terceiro milênio, olhemos para eles para não perder a confiança em nós e nos outros. Os santos são sinal de otimismo nas chances de cada um: dirijamo-nos a eles a fim de descobrir o santo que existe em nós; meçamo-nos com eles para compreender que Deus não está acostumado a aceitar derrotas em relação à fragilidade humana (PADOVESE, 2002, p. 7).

As festividades religiosas de contexto católico na Boa Vista do Padre João tomam proporção ampla na comunidade. apesar de haver muitas outras manifestações e outras ordens de fé. Porém, não são somente os fiéis católicos que participam desses festejos, a participação da comunidade geral é maciça fazendo com que muitas atividades e rituais tornem-se culturais e não somente de aspecto religioso, como por exemplo, as quermesses e os leilões. Momentos em que se encontram a comicidade e o riso, e seus promotores, os ridículos.

\section{Considerações Finais}

A vida árdua do povo nortista brasileiro não revela as belezas da sua cultura, do seu imaginário fértil, da sua devoção religiosa e do quanto esse povo sofrido gosta de rir. Esse passeio pelas memórias e pelas histórias da Boa Vista do Padre João fez-me rever os olhares desse povo. Aquele tom de tristeza, de uma vida vivida no sofrimento, fez com que eu me lembrasse da obra Vidas Secas, de Graciliano Ramos. Segue uma breve passagem do texto:

Indispensável os meninos entrarem no bom caminho. saberem cortar mandacaru para o gado, consertar cercas, amansar brabos. Precisavam ser duros, virar tatus. Se não calejassem, teriam o fim de seu Tomás da bolandeira. Coitado. Para que the servira tanto, livro, tanto jornal? Morrera por causa do, estômago doente e das pernas fracas (RAMOS, 1993, p. 24)

Mas, essa tristeza toda não toma conta de um mundo alegre e divertido que o norte do Brasil oferece. Território muitas

\section{Trânsitos Interdisciplinares em Artes}

Bárbara Tavares dos Santos, Liliane Scarpin S. Storniolo, Renata Patricia da Silva (Organizadoras)
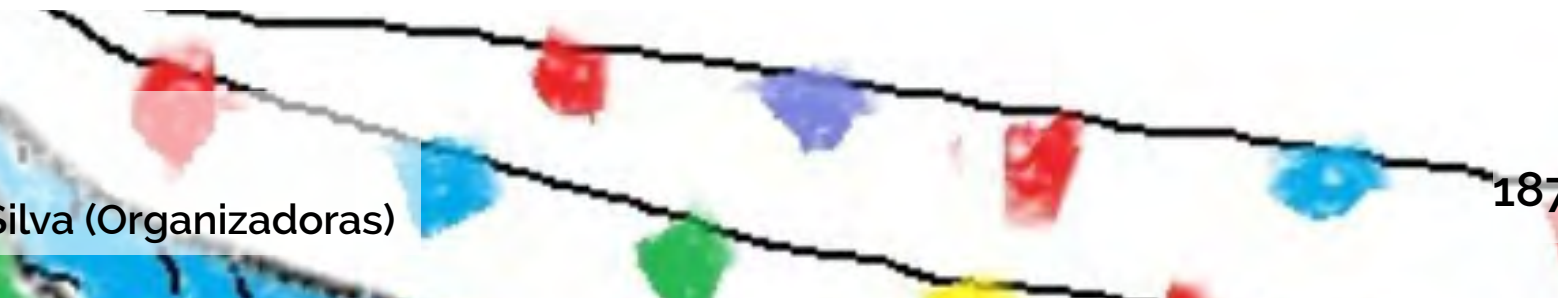
vezes esquecido pelos governos e pelos compatriotas de outras regiões. Um lugar de gente cômica, uma terra de gente ridícula. Sujeitos calejados pelo clima e as desgraças de uma nação que teima em esquecê-los, porém, sujeitos que reconstroem seu mundo pela cultura e pela ressignificação da sua existência.

Pesquisar, nesse sentido, sobre a comicidade e o riso sobre as coisas do outro, em especial em seu mundo de fé trouxeme, além da confirmação da tese, o respeito e a responsabilidade de tolerar e valorizar o outro e a sua espiritualidade. Os aspectos religiosos, que algumas vezes, fazem-nos repudiar alguém ou algo, diz mais sobre nós do que sobre o outro.

Às vezes eu penso: seria o caso de pessoas de fé e posição se reunirem, em algum apropriado lugar, no meio dos gerais, para se viver só em altas rezas, fortíssimas, louvando a Deus e pedindo glória do perdão do mundo. Todos vinham comparecendo, lá se levantava enorme igreja, não havia mais crimes, nem ambição, e todo sofrimento se espraiava em Deus, dado logo, até à hora de cada uma morte cantar (ROSA, 1994, p. 74).

Essa religiosidade, os espaços sagrados e os rituais de fé encontram-se nas celebrações que a igreja promove anualmente. Nesses espaços encontramos a comicidade e o riso, a alegria e a ludicidade, e até os palhaços da vida real, os ridículos. Amaral (2001, p. 2), sobre a ludicidade no contexto das festas religiosas diz que:

A festa religiosa parece representar, portanto, um espaço imaginário diferente, onde o homem se liberte do constrangimento das hierarquias econômicas e sociais, propondo seus ideais ou fantasiando sobre o futuro. Os mistérios e dramas litúrgicos são aspectos dessa imensa tentativa de impor ao mundo (desde o periodo feudal, pelo menos, e nas sociedades ocidentais) uma igualdade mítica que contradiz a realidade cotidiana: utopia viva, a festa supõe uma imagem do homem diferente daquela que the impõe o sistema social.

\section{Trânsitos Interdisciplinares em Artes}

Bárbara Tavares dos Santos, Liliane Scarpin S. Storniolo, Renata Patricia da Silva (Organizadoras) 
Até que ponto o ridículo deixa de ser profano e/ou sagrado para se tornar um espaço de "apaziguamento" entre esses dois mundos? O ridículo pode ser profano ou pode ser sagrado, mas essa não é a questão da tese. Então, o ridículo torna-se um meio de acalento com papel pacificador entre o sagrado e o profano quando ele deixa de ser somente profano e de ser somente sacro e se torna apenas o ridículo, lugar onde não há estranhamentos e o riso é livre e leve.

\section{Referências}

AMARAL, Rita. Festa à Brasileira: Sentidos do festejar no país que "não é sério". eBook, 2001

AZZI, Riolando. A Espiritualidade popular no Brasil: um enfoque histórico. In: Revista Grande Sinal. Petrópolis: Vozes, Ano XLVIII, pp. 293-304, 1994

BARROSO. Oswald. A Máscara: do Teatro Ritual ao Teatro Brincante. Fortaleza: Editora Armazém da Cultura, 2016.

BECKER, Udo. Dicionário de Símbolos. São Paulo: Paulus, 1999. BOYER, MarieFrance. Culto a Imagem da Virgem. São Paulo: Cosac e Naify Edições, 2000.

BAKHTIN, Mikhail. A cultura popular na Idade Média e no Renascimento: $O$ Contexto de François Rebelais. Tradução de Yara Frateschi Vieira. $7^{\text {a }}$ edição.

São Paulo: Hucitec, 2010

BERGSON. Henri. O Riso: Ensaio sobre a Significação da Comicidade. São Paulo: Martins Fontes, 2004

BIÃO, Armindo. Etnocenologia e a cena baiana: textos reunidos. Salvador: P\&A Gráfica e Editora, 2009

BIÃO, Armindo. Um trajeto, muitos projetos. In: BIÃO, Armindo. Artes do corpo e do espetáculo: questões de etnocenologia. Salvador: P\&A Gráfica e Editora, 2007

\section{Trânsitos Interdisciplinares em Artes}

Bárbara Tavares dos Santos, Liliane Scarpin S. Storniolo, Renata Patricia da Silva (Organizadoras) 
BIÃO, Armindo. Etnocenologia, uma introdução. In: BIÃO, Armindo e GREINER, Christine. Etnocenologia: textos selecionados. São Paulo: Annablume, 1999

BOYER, Marie-France. Culto a Imagem da Virgem. São Paulo: Cosac e Naify Edições, 2000

CASTRO, Almerindo Martins de. Antônio de Pádua: sua vida de milagres e prodígios. Rio de Janeiro: FEB, $7^{\mathrm{a}}$ ed., 1987.

CÔRTES, G. P. Dança, Brasil: festas e danças populares. Belo Horizonte: Leitura, 2000 .

DEL PRIORE, Mary Lucy. Festas e utopias no Brasil colonial. São Paulo: Brasiliense, 2000

DURKHEIM, Émile. As formas elementares de vida religiosa: $O$ sistema totêmico na Austrália. São Paulo: Paulus, 2001.

ELIADE, Mircea. O Sagrado e o Profano. Tradução Rogério Fernandes. São Paulo: Martins Fontes, 1992

GALVÃO, Antônio Mesquita. A Revelação de Jesus: na visita dos Reis Magos a Belém. São Paulo: Ave Maria, 2002.

IPHAN. Dossiê da Festa do Divino Espírito Santo de Pirenópolis. IPHAN, 2009. Disponivel em: http://portal.iphan.gov.br/uploads/ck $\square$ nder/arquivos/ Dossie_fes-ta_\%2odo_divino_pirenopolis.pdf

LE GOFF, Jacques. São Francisco de Assis. Tradução de Marcos de Castro. Rio de Janeiro: Record, 2001
MESQUITA, Fábio de Azevedo. A veneração aos Santos no Catolicismo popular brasileiro: uma aproximação histórico-teológica. In: REVELETEO - Revista Eletrônica Espaço Teológico, Vol. 9. n. 15, jan/jun., 2015, p. 155-174

NASCENTES, Antenor. Dicionário Etimológico da Língua Portuguesa. Rio de Janeiro-RJ: 1955.

NIETZSCHE, Friedrich. Assim falou Zaratustra: um livro para todos e para ninguém. Tradução de Mário da Silva. 18ª . ed. Rio de Janeiro: Editora Civilização Brasileira, 2010.

NIETZSCHE, Friedrich. ECCE HOMO: Como se chega a ser o que se é. Textos Clássicos de Filosofia. Tradução de Artur Morão. Covilhã: LusoSofia Press, 2008.

OLIVEIRA, Carla Mary da Silva. Arte, religião e conquista: os sistemas simbólicos do poder e o Barroco na Paraíba. João Pessoa: Dissertação de Mestrado UFPB, 1999

OLIVEIRA, Elza. Procissões - De estratégia de territorialidade à expressão de religiosidade popular. In: Sacrilegens - Revista dos Alunos do Programa de Pós-graduação em Ciência da Religião - UFJF, Juiz de Fora, v. 9. n.2, p. 15-32, jul-dez/2012.

OLIVEIRA, Joana Abreu Pereira de. Catirina, O Boi e sua vizinhança. Dissertação de mestrado. Universidade de Brasilia, 2006

PADOVESE, L. Diálogos entre Santos de Mármore. Petrópolis: Vozes, 2002

\section{Trânsitos Interdisciplinares em Artes}

Bárbara Tavares dos Santos, Liliane Scarpin S. Storniolo, Renata Patrícia da Silva (Organizadoras) 
PEREIRA, José Carlos. A Linguagem do Corpo na Devoção Popular do Catolicismo. In: REVER - Revista de Estudos da Religião, No 3, 2003, pp. 6798. Disponivel em: http://wwww.pucsp.br/rever/rv3_2003/p_pereira.pdf

PERGO, Vera Lucia, Os Rituais na Folia De Reis: uma das Festas Populares Brasileiras. In: Revista Brasileiro de História das Religiões. GT Religiões, edição especial Janeiro de 2012

PRADIER, Jean- Marie. Etnocenologia. In: BIÃO, Armindo e GREINER, Christine. Etnocenologia: textos selecionados. São Paulo: Annablume, 1999.

RAMOS, Graciliano. Vidas secas. São Paulo: Record, 1993.

RANGEL, Lúcia Helena Vitalli. Festas juninas, festas de São João: origens, tradições e história. São Paulo: Publishing Solutions, 2008.

ROSA, João Guimarães. Grande Sertão: veredas. Rio de Janeiro: Nova Aguilar. 1994
SANTOS, Márcia Pereira dos; DUARTE, Teresinha Maria. A escrita hagiográfica medieval e a formação da memória dos santos e santas católicos. Fazendo gênero 9. In: Anais Diáspora, diversidade. Deslocamentos. 23 a 26 de agosto de 2010. Disponivel em: http://Www.fazendogenero.ufsc.br/

SILVA, Renata de Lima; ROSA, Eloisa Marques. Performance Negra e a Dramaturgia do Corpo no Batuque. Rev. Bras. Estud. Presença. Porto Alegre. v. 7. n. 2, p. 249-273, maio/ago. 2017. Disponivel em: http://www.scielo.br/pdf/ rbep/v7n2/2237-2660-rbep-7-02-00249.pdf .

SOUZA, Maria Beatriz de Mello. Mãe, mestra e guia: uma análise da iconografia de Santa'Anna. In: Topoi, Rio de Janeiro, dezembro 2002, p. 232-250

TUAN, Yi-Fu. Espaço e lugar: a perspectiva da experiência. São Paulo: Difel, 1983

VALERI, Valério. Rito. In: Enciclopédia Einaudi - Vol. 30 - Religião-rito. Lisboa: Imprensa Nacional Casa da Moeda, 1994

\section{Trânsitos Interdisciplinares em Artes}

Bárbara Tavares dos Santos, Liliane Scarpin S. Storniolo, Renata Patricia da Silva (Organizadoras) 

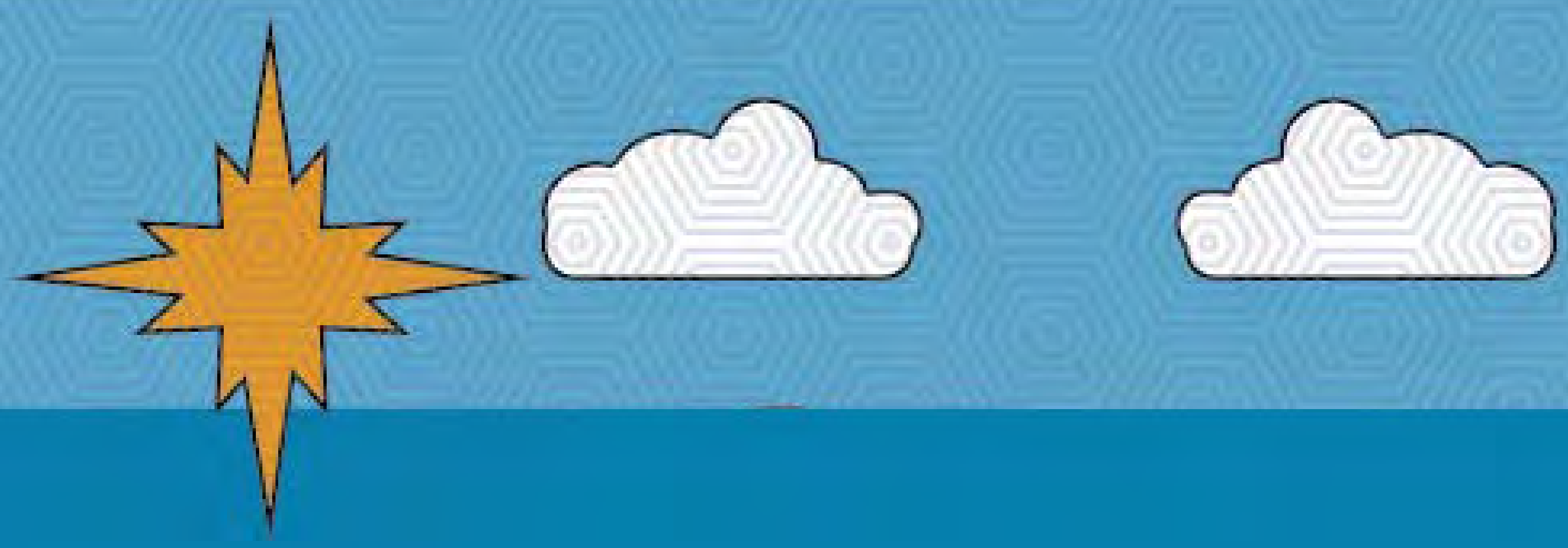


\section{Tradição nas Terras Tocantinenses: O Mito Fundador}

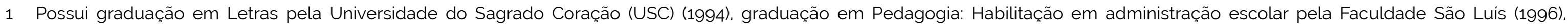

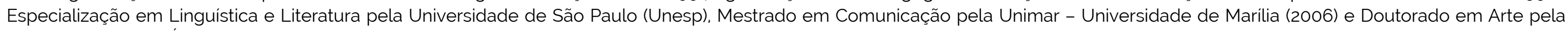
Unesp/UFT (2019). É professora efetiva da Unitins (Universidade Estadual do Tocantins), coordenadora do setor de Publicações e Edições, e-mail: liliane.ss@unitins.br.

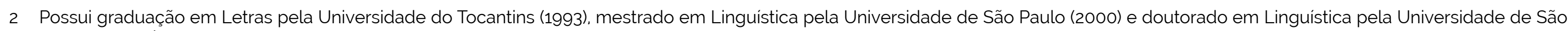

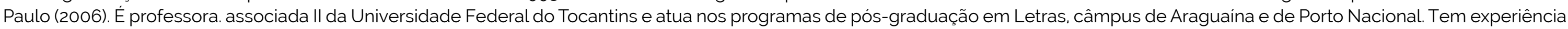

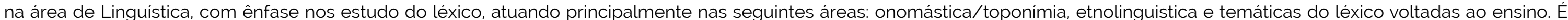
Bolsista Produtividade PQ2 CNPq, e-mail: karylleila@gmail.com.

\section{Trânsitos Interdisciplinares em Artes}

Bárbara Tavares dos Santos, Liliane Scarpin S. Storniolo, Renata Patrícia da Silva (Organizadoras)

Liliane Scarpin S. Storniolo ${ }^{1}$

Karylleila Andrade Klinger ${ }^{2}$ 
Este texto faz parte de minha tese de doutorado. Nele apresento o mito fundador do estado do Tocantins que foi a base para que eu pudesse discorrer sobre a cultura tocantinense, mais especificamente sobre as composições musicais desenvolvidas no estado, após sua emancipação política em 1988. Para tanto, destaco a figura política de José Wilson Siqueira Campos (1928)3.

3 Antônio de Siqueira Campos nasceu em Crato (CE) em 1928. Proprietário agrícola, industrial e pecuarista, foi vereador no municipio de Colinas de Goiás (GO) entre 1965 e 1967, tendo exercido a presidência da Câmara Municipal dessa cidade de 1966 a 1967. No pleito de novembro de 1970, elegeu-se deputado federal por Goiás na legenda da Aliança Renovadora Nacional (Arena), partido de sustentação do regime militar instalado no país em abril de 1964. Em outubro de 1980, foi denunciado por um dossiê do governo de estelionato, grilagem, suspeita de homicídios e falsidade ideológica. No pleito de novembro de 1986, foi eleito deputado federal constituinte pelo Partido Democrata Cristão (PDC). Defensor, desde 1974, da formação do estado de Tocantins, acabou tendo seu ponto de vista aceito pela Constituição de 1988, que autorizou a criação do novo estado, através do desmembramento do norte do estado de Goiás. Eleito em novembro de 1988 governador do estado recém-criado, licenciou-se da Câmara para exercer um mandato-tampão à frente do Executivo de Tocantins entre 1989 e 1991. Nas eleições de outubro de 1994, concorrendo na legenda do Partido Progressista Reformador (PPR), conquistou pela segunda vez o governo de Tocantins. No pleito de outubro de 1998, reelegeu-se governador, concorrendo na coligação que incluía, além do PFL, o PPB, o Partido Democrático Trabalhista (PDT), o Partido Popular Socialista (PPS), o Partido Socialista Brasileiro (PSB), o Partido Trabalhista Brasileiro (PTB), além de agremiações menores. Disponivel em: $\mathrm{http}: / / \mathrm{w} / \mathrm{ww} . \mathrm{fg} v \mathrm{br} / \mathrm{cpdoc} /$ acervo/dicionarios/verbete-biografico/campos-siqueira-2>. Acesso em 25 maio 2018. que é considerado, na história oficial do Tocantins, como um sucessor de Theotônio Segurado, como o "fundador" do estado. Rodrigues (2008, p.46) explica a influência do ex-governador: "Na 'árvore genealógica' do Tocantins, a 'Sagrada Familia' ou a 'dinastia' tocantinense tem Siqueira Campos como uma espécie de último herói com a missão de cumprir uma tarefa, um 'sonho acalentado' iniciado por Joaquim Teotônio Segurado".

Theotônio Segurado representava historicamente e, de acordo com a concepção da comunidade que habitava o norte goiano, o herói que fez a primeira manifestação pela autonomia do norte goiano. Então, Siqueira Campos, especialmente após 1970, quando foi eleito deputado Federal por Goiás, alia-se à representação política de Segurado com humildade, enaltecendo seus esforços em prol do povo do Norte. Nesse ato, toma para si o que considera a "missão" deixada por Segurado e se personifica como herói da pátria, defendida com a retórica aplicada em seus discursos nos palanques. O imaginário popular constrói, assim, um

\section{Trânsitos Interdisciplinares em Artes}

Bárbara Tavares dos Santos, Liliane Scarpin S. Storniolo, Renata Patrícia da Silva (Organizadoras)
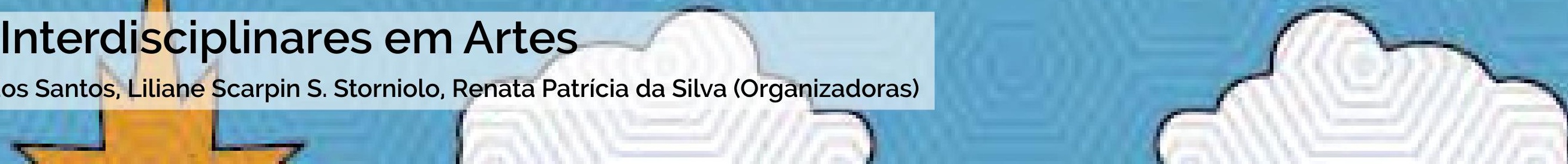
personagem com caracteristicas de mártir, próximo à imagem de um deus. Rodrigues (2008, p. 48) explica:

Os paralelos traçados entre os personagens dessa história - Siqueira Campos e Joaquim Theotônio Segurado - nos permitem identificar algumas semelhanças entre eles considerando, evidentemente, uma escala temporal ao longo da história tocantinense. Analisando seus discursos na Câmara dos Deputados e na Assembleia Nacional Constituinte no periodo de 1987 a 1988, notamos que: assim como Segurado, Siqueira Campos também se considera o defensor da causa do norte-nordeste goiano; suas ações no campo político culminam com a "independência" do norte de Goiás; e ele, a exemplo de seu antecessor. também foi governador.

De acordo com o autor, os feitos de Joaquim Theotônio Segurado estão presentes nos discursos de Siqueira Campos e são retomados frequentemente pelo ex-deputado e ex-governador com a finalidade de destacar que ele representa a sucessão histórica e política do ouvidor, construindo assim, o mito fundador do Tocantins.

Siqueira reaviva a imagem de Segurado como seu antecessor e inspiração nos seus discursos e em seus atos políticos. Esse fato pode ser constatado com a nomeação de uma das principais avenidas de Palmas, capital do Tocantins em 1991 sob sua gestão. Nesse sentido, Albuquerque Júnior (2001), defende que os conceitos criados para historicizar o passado e construir o presente não são passiveis de definição, esquematização, pois são apenas conectores de uma série de eventos realizados pelos representantes da história, nesse caso, Segurado e Siqueira Campos.

No hino do estado de Tocantins, oficializado pela lei estadual n 977, de 30 de abril de 1998, com letra de Liberato Costa Póvoa e a música de Abiezer Alves da Rocha, podemos avaliar a construção simbólica elaborada por um discurso metafórico que elenca as vitórias de "nossos" heróis.

\section{Trânsitos Interdisciplinares em Artes}

Bárbara Tavares dos Santos, Liliane Scarpin S. Storniolo, Renata Patrícia da Silva (Organizadoras) 
Mais um astro brilha dos céus aos confins Contra tudo e contra todos firme e forte Este povo forte

Do sofrido Norte

Teve melhor sorte

Nasce Tocantins

Levanta altaneiro, contempla o futuro

Caminha seguro, persegue os teus fins

Por tua beleza, por tuas riquezas

És o Tocantins!

Do bravo Ouvidor a saga não parou

Contra a oligarquia o povo se voltou

Somos brava gente

Simples, mas valente

Povo consciente

Sem medo e temor
Contra a tirania

Da oligarquia

O povo queria

Libertar o Norte!

Teus rios, tuas matas, tua imensidão

Teu belo Araguaia lembra o paraíso

Tua rica história

Guardo na memória

Pela tua Glória

Morro, se preciso!

Pulsa no peito o orgulho da luta de Palma

Feita com a alma que a beleza irradia

Vejo tua gente

Tua alma xerente

Teu povo valente

Que venceu um dia!

(Liberato Póvoa e Abiezer Alves da

Rocha) ${ }^{1}$
Nota-se que o texto recupera todo o mito fundador do estado do Tocantins, contando as agruras pelas quais o povo sertanejo passou até chegar à "terra prometida" (Este povo forte/ Do sofrido Norte/ Nasce Tocantins). Com utilização de metáforas descortina as belezas do Tocantins o ato heroico de Teotônio Segurado que conclamou o povo para a luta (Do bravo Ouvidor a saga não parou/Contra a oligarquia o povo se voltou/Somos brava gente/ Simples, mas valente). Em seguida ressalta a continuidade do heroísmo (De Segurado a Siqueira o ideal seguiu/ Contra tudo e contra todos firme e forte). Para finalizar, mostra a libertação do norte goiano e a alegria da conquista (Pulsa no peito o orgulho da luta de Palma/ Vejo tua gente/ Que venceu um dia!). Essa construção discursiva é edificada em metáforas que

[...] proliferam o sentido, porque interiorizam diferenças. As metáforas são risos dos conceitos, são dobras. dissonâncias, rompendo com o conceito como único lugar da verdade. Elas são formas de comunicar o "real" em sua complexidade de significação, que nos falam da

\section{Trânsitos Interdisciplinares em Artes}

Bárbara Tavares dos Santos, Liliane Scarpin S. Storniolo, Renata Patrícia da Silva (Organizadoras)
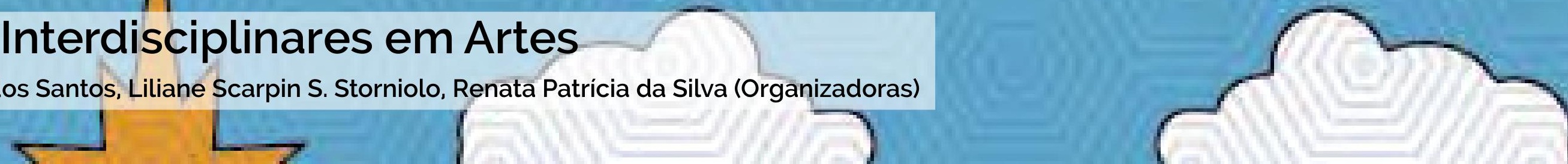
impossibilidade do conhecimento de mundo somente por meio do conhecimento empírico ou conceitual [...] (ALBUQUERQUE JÚNIOR, 2001, p. 33).

O efeito metafórico trazido pelo texto proporciona uma análise interpretativa do funcionamento discursivo, pois o compositor utiliza sua noção de memória discursiva e a relaciona com os sentidos reais das palavras em uma substituição passivel de interpretação, um texto que faz sentido por meio da linguagem poética.

Portanto, a canção é composta com bases poéticas que viabiliza o discurso e o torna persuasivo, um hino para o povo do Norte que não precisa mais submeter-se a outro governo que não seja seu, do seu lugar, da sua região. Essa confiança nascida com o Tocantins, desperta em sua população, imbuida de nacionalismo/ regionalismo, a crença de que tudo será diferente e que farão parte da construção de um novo tempo, melhor e mais produtivo do que outrora. Portanto a canção os representa.
Segundo Rodrigues (2008, p. 49), os nomes de Segurado e Siqueira Campos no hino do estado do Tocantins evidenciam a utilização e a manipulação da construção dos símbolos regionais, fabricando uma imagem "de continuidade histórica e de heroísmo dos dois personagens na construção da identidade regional". Verifica-se, então, que a criação do estado do Tocantins foi moldada pela estruturação de um espaço de representação que funcionou na elaboração do imaginário social que considera a dicotomia entre o sul e o norte. Para que houvesse efetivamente a consolidação da criação do estado do Tocantins, era preciso que se estabelecessem símbolos e tradições próprios do antigo norte goiano.

\section{A criação de símbolos e tradições}

A identidade cultural do estado do Tocantins foi vista como um problema pelo movimento autonomista, pois havia se instaurado diferenças etnográficas sobre rituais, costumes e práticas comuns.

\section{Trânsitos Interdisciplinares em Artes}


Esse fato deve-se à ocupação do então Norte goiano que, além de sua população nativa, recebia habitantes de diversos lugares do Brasil e também estrangeiros. Portanto, o estado era composto por um contingente populacional que formava um conjunto híbrido das representações religiosas e sociais, um espaço multicultural. Dessa forma, era necessária a criação de uma representação que conseguisse realizar uma junção das tradições, símbolos e outros fatores que identificassem o povo tocantinense. O historiador britânico Eric John Ernest Hobsbawm (1917-2012) desenvolveu para essas situações que requerem a criação de relações identitárias, uma concepção a qual denominou "tradição inventada":

Por 'tradição inventada' entende-se um conjunto de práticas, normalmente reguladas por regras tácita ou abertamente aceitas; tais práticas, de natureza ritual ou simbólica, visam inculcar certos valores e normas de comportamento através da repetição, o que implica, automaticamente: uma continuidade em relação ao passado. Aliás, sempre que possivel, tenta-se estabelecer continuidade com um passado histórico apropriado (HOBSBAWM: RANGER, 2008, p. 9).
É importante salientar, conforme dito pelo autor. que nenhuma tradição ou símbolo pode ser criado por uma vontade individual, mas parte do coletivo, por meio de relações estabelecidas entre os fatos presentes e de um passado histórico apropriado. Levando-se em consideração o momento histórico da criação do estado do Tocantins, seu mito fundador, criam-se vários símbolos com a ideia de se edificarem o novo estado e se tornarem tradição. Nessa construção também se leva em consideração uma condição essencial imposta pelos separatistas além da viabilidade econômica, a dicotomia que deveria existir entre tocantinenses e goianos. De acordo com Rodrigues (2012, p. 480), era preciso produzir "uma identidade regional tocantinense que pudesse legitimar, do ponto de vista cultural e subjetivo, sua viabilidade a partir da exploração das diferenças e exclusões entre tocantinenses e goianos". Dessa forma, seria construido "nos sujeitos sentimentos e representações de pertencimento regional tocantinense".

Para tanto, foi necessário que se avaliasse o que já era conhecido pela população do norte de Goiás e poderia ser "re-

\section{Trânsitos Interdisciplinares em Artes}

Bárbara Tavares dos Santos, Liliane Scarpin S. Storniolo, Renata Patrícia da Silva (Organizadoras)

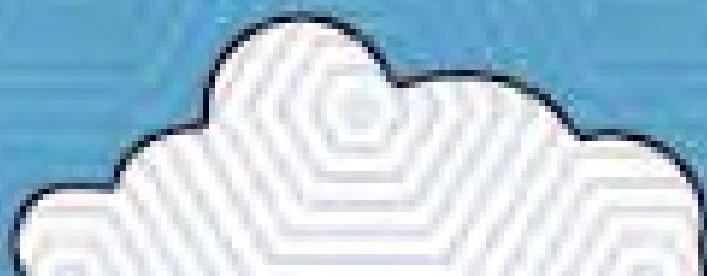


criado". Hobsbawm e Ranger (2008) consideram que "a invenção das tradições é essencialmente um processo de formalização e ritualização, caracterizado por referir-se ao passado, mesmo que pela imposição da repetição". De acordo com o Instituto do Patrimônio Histórico e Artístico Nacional IPHAN4:

A Constituição Federal de 1988, em seu Artigo 216, ampliou o conceito de patrimônio estabelecido pelo Decreto-lei nº 25. de 30 de novembro de 1937. substituindo a nominação Patrimônio Histórico e Artístico, por Patrimônio Cultural Brasileiro. [...] o patrimônio cultural de um povo é formado pelo conjunto dos saberes, fazeres, expressões, práticas e seus produtos, que remetem à história, à memória e à identidade desse povo. [...] é também fruto de uma escolha, que, no caso das políticas públicas, tem a participação do Estado por meio de leis, instituições e políticas especificas. Essa escolha é feita a partir daquilo que as pessoas consideram ser mais importante, mais representativo da sua

4 Disponivel em: <http://portal.iphan.gov.br/pagina/detalhes/218>. Acesso em 27 abr. 2018 identidade, da sua história, da sua cultura, ou seja, são os valores, os significados atribuidos pelas pessoas a objetos, lugares ou práticas culturais que os tornam patrimônio de uma coletividade (ou patrimônio coletivo).

Para Oliveira (2012, p. 276), no Tocantins cria-se "[...] uma política de construção de uma nova identidade cultural, econômica e política, construindo alegorias, disseminando fatos e mitos pouco representativos à história da então região norte de Goiás". Assim, forjam-se símbolos, mitos, imagens e fatos atribuindo sentidos às representações que já existiam na região. Para tanto, buscaramse na história, especialmente no interior do estado, símbolos que faziam parte do cotidiano dos habitantes, portanto com valor sentimental. Um exemplo é na culinária, cujo processo histórico reúne um conjunto de elementos tradicionais, que são transmitidos hereditariamente, criando, dessa forma, "algo particular, singular e reconhecivel, um projeto coletivo que inclui uma constante reconstrução" (MACIEL, 2006, p. 90).

\section{Trânsitos Interdisciplinares em Artes}

Bárbara Tavares dos Santos, Liliane Scarpin S. Storniolo, Renata Patrícia da Silva (Organizadoras) 
No Tocantins encontramos vários sabores surpreendentes, entre eles, o tradicional Amor Perfeito, que é um biscoito de polvilho, como formato de coroa, que teve considerada sua produção original em Natividade. Sua tradição vem da simplicidade com que é produzido há mais de 100 (cem) anos, de maneira artesanal. Com a herança de sua mãe, hoje quem organiza a produção aos 74 (setenta e quatro) anos de idade, é a uma senhora, conhecida como Tia Naninha. De acordo com o que foi exposto, o Amor Perfeito transformou-se em um símbolo da cultura tocantinense.

Ao falarmos em símbolo, é importante que conheçamos a utilização da palavra no contexto cultural. Para tanto, observaremos os preceitos da teoria semiótica ${ }^{5}$ de acordo com o filósofo americano Charles S. Pierce (1839-1914), na qual o símbolo 6 é utilizado para representar o mundo e somente vai ter sentido ser for um signo7 reconhecido para quem é destinado. Nesse contexto, os símbolos criados para o povo tocantinense foram "emprestados" de representações existentes em outras instituições que já faziam parte do cotidiano da população de localidades do estado.

Outro símbolo que merece destaque é a imagem de Nossa Senhora da Natividade que foi institucionalizada como padroeira do estado, visto que, a população já tinha devoção à santa e rendiam homenagens a ela com festividades. A criação de toda essa simbologia facilitou a aceitação e promoveu o sentimento

5 "O nome Semiótica vem da raiz grega semeion, que quer dizer signo. Semiótica é a ciência dos signos" (SANTAELLA, 1998, p. 5).

6 "O símbolo [...] não representa seu objeto em virtude do caráter de sua qualidade [...], mas extrai seu poder de representação porque é portador de uma lei que, por convenção ou pacto coletivo, determina que aquele signo represente seu objeto" (SANTAELLA, 1998, p. 42).

7 O signo representa o ser humano enquanto um ser de linguagem, ou seja, as expressões que utiliza para se comunicar, as palavras e seu contexto (SANTAELLA, 1998).

\section{Trânsitos Interdisciplinares em Artes}

Bárbara Tavares dos Santos, Liliane Scarpin S. Storniolo, Renata Patricia da Silva (Organizadoras)

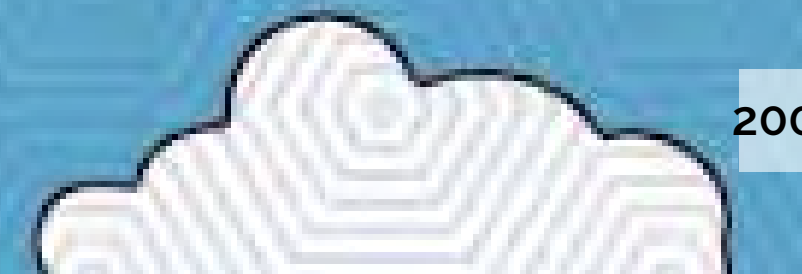


de pertencimento ao "novo" lugar8, solidificado por tradições que seriam perpetuadas de acordo com os discursos das pessoas que detinham o poder na política e na religião.

Assim também, as figuras dos heróis foram consolidandose como símbolos pela luta na criação do estado. Para que isso acontecesse, os governantes investiram nos compositores regionais para que compusessem canções nesse sentido. Assim, a produção musical naquele momento foi muito promissora quanto ao estabelecimento das características do "Paraíso terreal"9 encontrado no Tocantins. Uma das canções que representa esse momento é "Catirandê. Catirandá" do compositor Mamedkarin:

8 Aqui se busca "compreender o lugar através de nossas necessidades existenciais quais sejam, localização, posição, mobilidade, interação com os objetos e/ou com as pessoas. Identifica-se esta perspectiva com a nossa corporeidade e, a partir dela, o nosso estar no mundo, no caso, a partir do lugar como espaço de existência e coexistência" (SUERTEGARAY, 2001, s/p).

9 Paraiso terreal é a expressão utilizada por Sérgio Buarque de Holanda ao descrever as belezas naturais vistas pelos estrangeiros em seu livro "A visão do Paraíso" (1959).
Dá licença de eu contar Uma história tocantina, nessa catira esmilinguida, dá licença d'eu falar.

Que esse norte goiano era esquecido e abandonado O homem de Deus vem nos salvar. qual faraó via água grande chegar.
O povo sofria qual gado com intemperança do tempo do sul veio um cavaco, mas do céu a providência.

Um homem iluminado, contra a demência da riqueza da nação que negara a independência pra esse querido Tocantins de José e Segurado.

Inicialmente o compositor nos convida para uma contação de história (Dá licença de eu contar/uma história tocantina) e propõe utilizar um ritmo já conhecido no norte goiano, a catira. Então, por meio da constatação de fatos que foram considerados históricos e pelas metáforas, compõe a história da "libertação" do Tocantins. Utiliza-se também de um neologismo para o adjetivo pátrio de alguém que é do Tocantins (tocantina). Nas palavras do compositor o povo do norte goiano era esquecido e abandonado. Então, como um milagre aparece, não qualquer herói, o compositor

\section{Trânsitos Interdisciplinares em Artes}

Bárbara Tavares dos Santos, Liliane Scarpin S. Storniolo, Renata Patrícia da Silva (Organizadoras)

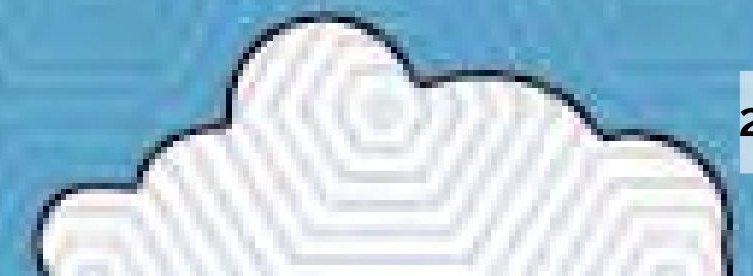


utiliza o artigo definido "o" para se referir a um homem apenas, aquele que foi designado por Deus para salvar o povo (O homem de Deus), assim como Moisés salvou o povo israelita que iria ser dizimado pelo exército do Faraó no Egito, abrindo o mar vermelho ${ }^{10}$, Siqueira Campos conduziu o povo tocantinense à "terra prometida". Essa intertextualidade com o texto bíblico reforça a representação e o simbolismo de Siqueira Campos como um homem iluminado e temente a Deus que protegeu o Norte dos ataques do Sul "do sul veio um cavaco", pois veio "do céu a providência" e o Tocantins iniciou sua existência. No último verso da canção, o compositor lembra que quem iniciou a luta foi Teotônio Segurado e quem a venceu foi José Wilson Siqueira Campos, portanto, ambos são considerados mitos políticos, os idealizadores do estado.

Apesar de considerar Teotônio Segurado como parte importante da história do Tocantins, Siqueira Campos toma para

10 Biblia Sagada, Êxodo 14. Disponivel em: <https://www.bibliaonline.com.br/acf/ex/14>, Acesso em: 19 abr. 2018. si sua criação. O jornalista Philipe Bastos, numa matéria para o portal "Conexão Tocantins" em 2010, comenta o discurso do então candidato ao governo do estado que utiliza "o tom de pai do Tocantins". Nas palavras de Siqueira: "Lutei 40 anos pela criação do estado. Fiz greve de fome e fui preso. Sofri que nem couro de picar fumo. Mas não separei esta região do norte de Goiás para voltar a ser corredor da miséria". Observa-se que é ressaltada, tanto na letra da canção, como na fala de Siqueira, a dicotomia entre o Norte e o Sul, fato esse que aparece constantemente na história do Tocantins no sentido de validar sua existência, fazer com que haja esse desconforto, uma disputa entre as regiões agora separadas.

A imagem reforça as palavras proferidas por Siqueira na entrevista citada anteriormente na qual ressalta o que considera um ato de coragem e resistência, sua greve de fome para que o Tocantins fosse um estado autônomo. Esse ato deixou o povo do norte goiano consternado e Siqueira conseguiu ainda mais popularidade em 1985

\section{Trânsitos Interdisciplinares em Artes}


A popularidade de Siqueira Campos ainda é forte no Tocantins. Atualmente houve uma exposição no Memorial Coluna Prestes, na Praça dos Girassóis que inicialmente duraria três meses (de 15/03/19 a 19/06/19). mas foi prorrogada até 28 de junho. Com o título "Siqueira Campos, um estadista: do setentrião goiano ao Tocantins", o evento reforçou a importância do ex-governador para o Tocantins, apresentando sua história por meio de

[...] uma linha do tempo desenvolvida por meio de 24 painéis com cerca de 80 fotos, inclusive inéditas, complementadas com textos, contextualizando os fatos históricos da criação do Estado no mesmo período de acontecimentos relevantes com repercussões regionais, nacionais e mundiais, como a independência do Brasil e a Revolução Francesa ${ }^{11}$

No cartaz que fazia a publicidade da exposição, patrocinada por empresas locais importantes, como por exemplo,

11 Disponivelem:<https://portal.to.gov.br/noticia/2019/6/18/exposicao-em-homenagema-siqueira-campos-e-prorrogada-ate-28-de-junho/>. Acesso em: 18 jun. 2019. a Energisa, há uma pomba branca sobre o mapa do Tocantins que pode simbolizar o "Divino", ou seja, a figura bíblica que representa o pai, o filho e o espírito santo, uma alusão ao personagem principal do evento que influencia muitas pessoas na crença de estarem sob sua proteção.

\section{Estratégias simbólicas}

Rodrigues (2008) esclarece que foram diversas as estratégias usadas para avivar constantemente os atos "heroicos" dos governantes tocantinenses. Houve a instituição do feriado de 18 (dezoito) de março, quando se comemora o "Dia da Autonomia do Tocantins", criou-se o brasão e a bandeira, símbolos que reforçam o mito fundador, atualizando no imaginário popular a memória das figuras heroicas na emancipação do estado.

Um dos símbolos criados como representante da natureza do Tocantins no governo Siqueira Campos é o girassol. Esse símbolo foi difundido ostensivamente em todas as gestões do ex-

\section{Trânsitos Interdisciplinares em Artes}

Bárbara Tavares dos Santos, Liliane Scarpin S. Storniolo, Renata Patrícia da Silva (Organizadoras)

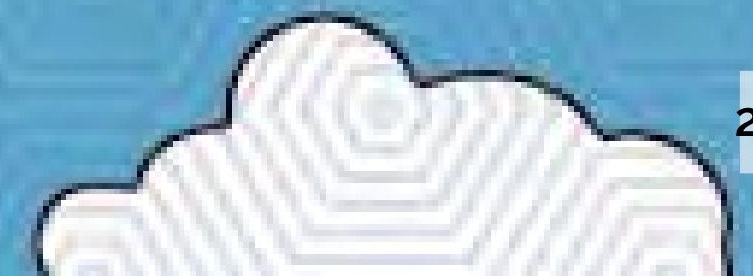


governador (1989 a 1991; 1995 a 1998; 1999 a 2002; 2011 a 2014) e deu nome a praça que abriga os prédios do governo estadual na capital do estado e que considerada a maior da América Latina. Para Oliveira (2012, p. 141):

[...] pode-se discutir o perfil do primeiro governador a partir da seleção dos símbolos do estado e da capital. Para a capital, foi escolhido o girassol, talvez pela beleza da planta, não pelo o que ela representa para um estado da região norte, que conta com uma das maiores diversidades de plantas do Brasil. Por isso, pegar uma planta fora do bioma do estado, no mínimo, é desconhecer a realidade ou para satisfazer particular de quem comanda, que preferiu não consultar a população ou especialistas sobre as melhores opções para simbolizar a cidade.

Dessa forma, entende-se que se trata de um símbolo imposto. Em uma entrevista concedida ao jornalista Sidney Neto da TV Anhanguera em 2016. Siqueira Campos, primeiro governador do Tocantins, explica o simbolismo do girassol. Diz que a planta é vinculada ao passado histórico de Tocantins e simboliza uma ligação identitária e histórica com Teotônio Segurado. Fala que percebeu essa ligação visitando os campos de girassol portugueses da terra natal de Segurado, ressalta a beleza dessa plantação, seu encanto com suas cores e a prosperidade representada por ela "Tocantins e os girassóis, todos estão ligados há muito tempo" (CAMPOS, 2016). Siqueira apresenta também uma pedra que foi localizada no Tocantins cuja imagem diz ser de um fóssil de girassol, indicando ter existido a planta nas terras do estado em tempos remotos, faz quase que uma premonição para o símbolo criado. Além do discurso inflamado, diversos atos do então governador para a solidificação do girassol como símbolo foram realizados durante os 15 (quinze) anos que ocupou o cargo de governador do estado.

A criação do Brasão de Armas do Tocantins foi instituida pela lei no 092/89, de 17 de novembro de 1989, publicada na primeira Constituição do Estado do Tocantins e decretada

\section{Trânsitos Interdisciplinares em Artes}

Bárbara Tavares dos Santos, Liliane Scarpin S. Storniolo, Renata Patrícia da Silva (Organizadoras)

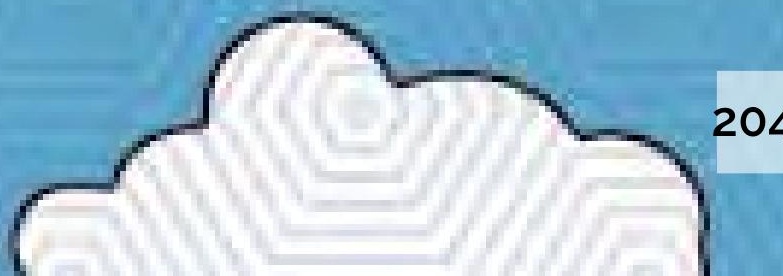


pela Assembleia Legislativa. De acordo com a Secretaria de Comunicação do Tocantins (SECOM) ${ }^{12}$, o brasão foi criado de acordo com as seguintes especificações:

[...] a mensagem principal decifrada através da frase CO YVY ORE RETAMA, que significa, em tupi guarani: "ESTA TERRA É NOSSA", o Brasão do Tocantins também mostra em destaque a data de instalação do Estado: $1^{\circ}$ de janeiro de 1989. Cada elemento da sua composição traz um significado: os ramos que crescem nos dois lados do Brasão representam nossas riquezas naturais. As duas faixas azuis, direcionadas para o alto, dentro da figura o valar do Brasão, representam os dois rios tocantinenses: Tocantins e Araguaia. Os elementos em branco, juntamente com o sol amarelo-ouro sobre um fundo azul, compõem a mensagem que transmite a certeza de um futuro iluminado. A faixa amarela, abaixo das faixas azuis, significa as riquezas minerais do Tocantins.
Assim, o simbolo representado pelo brasão enaltece a presença indígena no estado, as riquezas naturais e, sobretudo, por meio da coroa de louros que representa os heróis vitoriosos que transformaram o sonho tão longinquo da emancipação em realidade e, por fim, a expressão Akwen "CO YVY ORE RETAMA", que significa "Esta terra é nossa" (RODRIGUES, 2008).

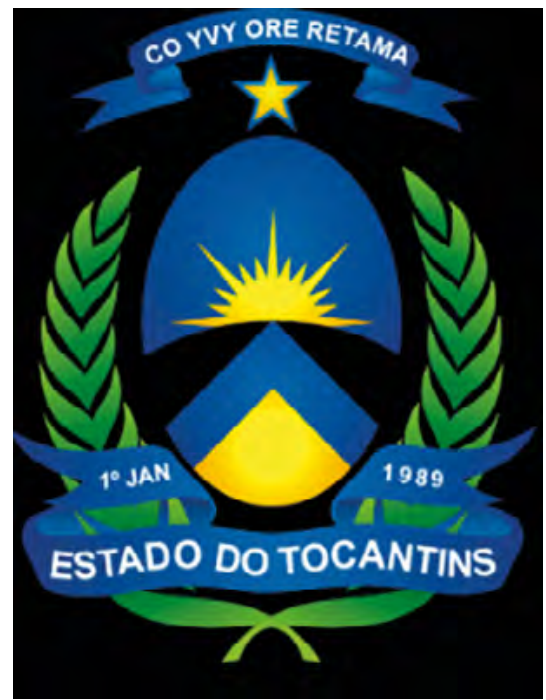

Brasão de Armas do Estado do Tocantins. Fonte: Rodrigues (2008, p. 55). 
Quanto à bandeira do Estado, sua criação foi instituida pela lei nº 094/89, de 17 de novembro de 1989, decretada pela Assembleia Legislativa, na primeira Constituição do Estado do Tocantins. Rodrigues (2008, p. 56), expõe a visão da Secretaria de Educação e Cultura do Estado do Tocantins:

[...] a Bandeira, como símbolo máximo a pairar sobre o novo Estado do Tocantins, deve ser a sintese dos sonhos e ideais mais caros de seu povo: a reverência ao seu passado, a confiança no seu presente e a esperança no seu futuro, representando todos esses valores da forma mais harmônica possivel.

A Secretaria de Comunicação (SECOM), explica de maneira breve a construção da bandeira:

[...] a Bandeira do Tocantins traz as seguintes mensagens, de acordo com suas cores e símbolos: a faixa branca, localizada ao centro com um sol amarelo-ouro a derramar seus raios sobre o futuro do novo Estado, traz a mensagem principal do símbolo: de uma terra onde o sol nasce para todos. A barra branca representa o cultivo da paz. A faixa em azul representa nossos mananciais de água, enquanto a amarela representa o ouro, as riquezas do Estado.

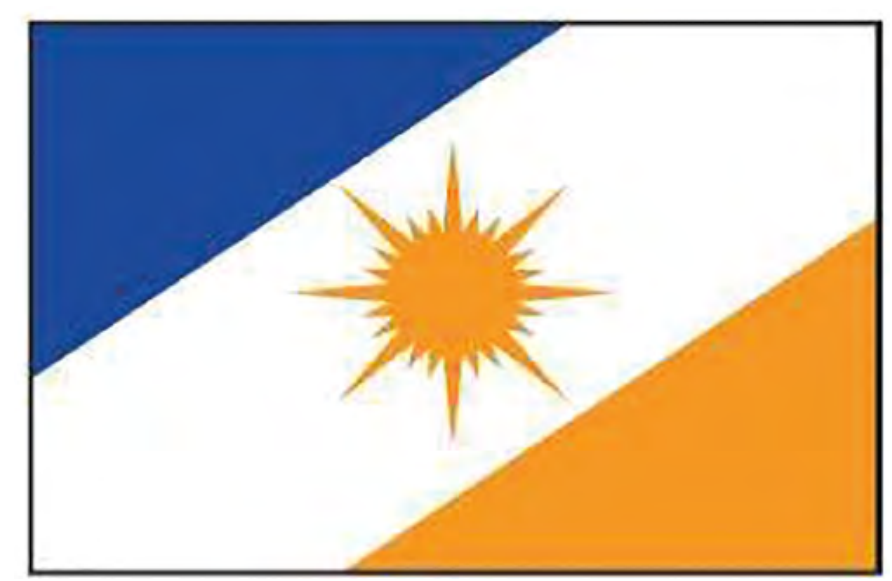

Bandeira do Estado do Tocantins. Fonte: Rodrigues (2008, p. 56).

Ao analisarmos os eventos históricos envolvidos no discurso da criação do estado do Tocantins, constatamos que esses simbolos reforçam a ideia de que o estado somente será

\section{Trânsitos Interdisciplinares em Artes}

Bárbara Tavares dos Santos, Liliane Scarpin S. Storniolo, Renata Patricia da Silva (Organizadoras)

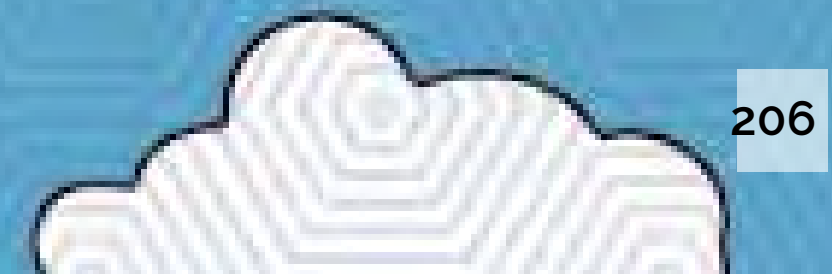


promissor se forem levadas em consideração as falas recorrentes dos governantes sobre a valorização do "ouro verde" (a natureza) e da manutenção de tradições que foram criadas com a finalidade de formar a identidade do estado. Para que seja eficiente, a propagação dessa ideologia deve acontecer por meios que sensibilizem o povo e, o canal que propicia essa sensibilidade é o discurso. Para o filósofo francês Michel Foucault (1926-1984), o discurso é um conjunto de enunciados que são representados pela linguagem. Funciona como um jogo no qual estão presentes as armas para que o enunciador consiga a adesão dos enunciatários (1999)

Para que o estado fosse completo, era necessário que se construísse uma capital onde seria criada a sede do governo que teria as caracteristicas futuristas imaginadas por seus idealizadores.

\section{Palmas: a capital do futuro}

Nossos sentimentos

Foram

Coloridos

Artificialmente

Numa cidade

Artificialmente

Criada

Artificialmente

Acrescentando gente

Artificialmente

\section{Trânsitos Interdisciplinares em Artes}

Bárbara Tavares dos Santos, Liliane Scarpin S. Storniolo, Renata Patricia da Silva (Organizadoras)

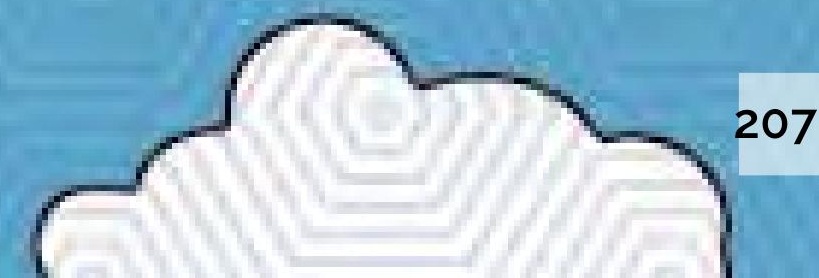


No trecho do poema "Contorno palmacético" do escritor palmense Thiago Ramos de França, tudo o que existe na cidade de Palmas foi criado artificialmente, o que é a realidade, visto que, a cidade é planejada, tendo como inspiração o Distrito Federal.

De acordo com a professora Carminda Mendes André (2018, p.74). somos herdeiros de cidades do continente europeu, nas quais o centro urbano funcionava como espaço onde ocorriam festas, encontros e eventos sociais ou abrigavam "projetos a partir de uma racionalidade complexa (modos de vida imaginários e projetados por poetas e arquitetos, urbanização higiênica e estatal, urbanismo dos vendedores imobiliários)". Acredita-se que a construção de Palmas teria sido pensada em relação à segunda opção apresentada. A autora defende que

Palmas teve um centro urbano que deu suporte inicial às familias que chegaram para trabalhar na construção da cidade e, ao mesmo tempo, também foi ela produto de uma racionalidade desenraizada da localidade. [...]
Palmas não tem centro histórico, seu marco zero é uma praça projetada previamente pelo projeto urbano que the deu materialidade.

Palmas foi fundada logo após a criação do estado do Tocantins em 1989, entre a Serra do Lajeado e o rio Tocantins. O nome da cidade foi escolhido por Siqueira Campos como homenagem à Comarca de Palmas, onde nasceu, em 1821, o movimento emancipacionista do Tocantins. O marco zero da cidade está na Praça dos Girassóis, local onde se encontra o Palácio do governo. Palácio Araguaia. Pela Lei 985 de 25 de abril de 2001 foi instituida a canção "Amor a Palmas" como hino popular de Palmas. De acordo com a redação da Lei que foi alterada em 2012 com uma redação mais clara que deixa explicita sua autoria: "Art. $1^{\circ}$ É adotado como "Hino Popular de Palmas" a Canção de Amor a Palmas, letra e música de autoria de Braguinha Barroso e Neusinha Bahia, com arranjos para banda de autoria de Rildo Gomes e para o

\section{Trânsitos Interdisciplinares em Artes}

Bárbara Tavares dos Santos, Liliane Scarpin S. Storniolo, Renata Patrícia da Silva (Organizadoras)

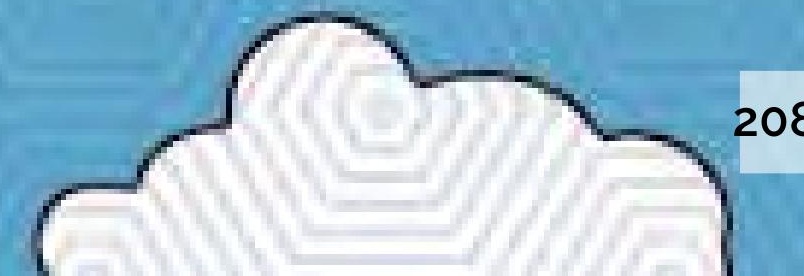


coral, autoria de Cleber Araújo"13. Vejamos a letra da canção "Amor a Palmas".

Palmas, na manhã do teu nascer,

vejo a esperança florescer

num sonho lindo de viver; Vejo o futuro no horizonte,

o teu povo vem à fonte

no coração de quem quer vencer.

Tua grandeza depende dessa gente,

que unida te fará maior. Te amo, Palmas,

e no seio de tuas serras

recebeste todos

e os fizeste filhos da terra.

13 Disponivel em: <https://leismunicipais.com.br/a/to/p/palmas/lei-ordinaria/2012/192/ 1917/lei-ordinaria-n-1917-2012-altera-a-lei-n-985-de-25-de-abril-de-2001-que-adota-acancao-de-amor-a-palmas-como-hino-popular-de-palmas-na-forma-que-especifica>. Acesso em: 30 maio 2019
Te amo, Palmas,

e a beleza do pôr-do-sol

e o berço de tua história

onde vivem os girassóis.

Te amo, Palmas,

como amo o Tocantins,

e abriste os portais

dessa beleza sem fim.

Verifica-se que a letra é simples, com versos fáceis de serem assimilados. O enunciador coloca-se em primeira pessoa, ressalta a grandeza do povo advindo de diversos locais do país em busca de prosperidade e que é muito bem recebido pela cidade que tem a vocação para crescer impulsionada por essas pessoas que acreditam em seu potencial.

O enunciador prossegue sua fala exaltando uma das belezas naturais mais admiradas da cidade, o pôr-do-sol. Cita

\section{Trânsitos Interdisciplinares em Artes}

Bárbara Tavares dos Santos, Liliane Scarpin S. Storniolo, Renata Patricia da Silva (Organizadoras)

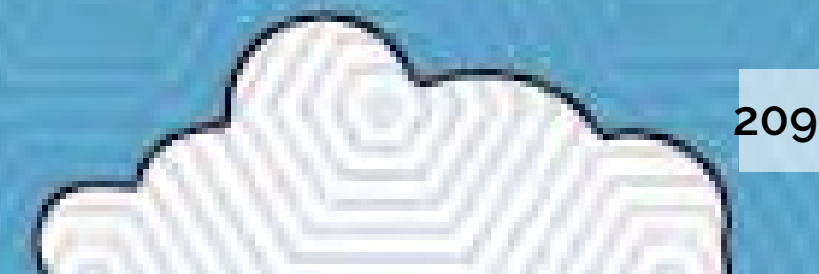


também a flor que é considerada seu símbolo, o girassol. Por fim, declara todo seu amor a Palmas, cujo sentimento é comparado ao que sente pelo Tocantins. Esse hino é cantado em eventos oficiais da cidade nos quais se apresentam, com frequência, músicos regionais que ao cantá-lo são acompanhados pelo coro de espectadores. Conforme pudemos observar na comemoração do aniversário de 30 (trinta) ${ }^{14}$ anos da cidade em 20 (vinte) de maio deste ano.

\section{Praça dos Girassóis: o tempo ausente}

De acordo com a geógrafa Valéria Cristina Pereira da Silva (2008), a imagem da cidade de Palmas, capital do Tocantins, é composta por uma relação entre mito, poder e estética que não pode ser dissociada de Siqueira Campos, seu "idealizador",

14 Publicidade da Prefeitura de Palmas nos seus 30 anos. Disponivel em: <https://www. youtube.com/watch?V=LwWoAPrs1Vk>. Acesso em: 4 jun. 2019. apesar de existirem críticas à sua postura autoritária. Trata-se de uma cidade projetada que tem entre suas caracteristicas o tempo ausente:

O tempo desfiado de seu novelo salpica o espaço de intenções e gesto - a cidade do tempo ausente. paradoxalmente, está imbricada numa teia temporal - pois no tempo ausente, outros tempos se conjugam e a sua história é a história de um passado longínquo, mítico, de outrora, desencaixado e, ao mesmo tempo, do amanhã. do devir. O presente da cidade está nas suas dobras, é sua condição pós-moderna (SILVA, 2008, p. 33).

A criação da Praça dos Girassóis segue no sentido do tempo ausente, pode ser considerada uma obra pós-moderna com a apresentação de diversos estilos artísticos e suas temporalidades, do presente, do passado e que remetem ao futuro. Traz em sua composição uma multiplicidade de referências por meio da representação de fatos históricos que não são interligados, mas apresenta a visão de uma colcha de retalhos, cuja realidade

\section{Trânsitos Interdisciplinares em Artes}

Bárbara Tavares dos Santos, Liliane Scarpin S. Storniolo, Renata Patrícia da Silva (Organizadoras)

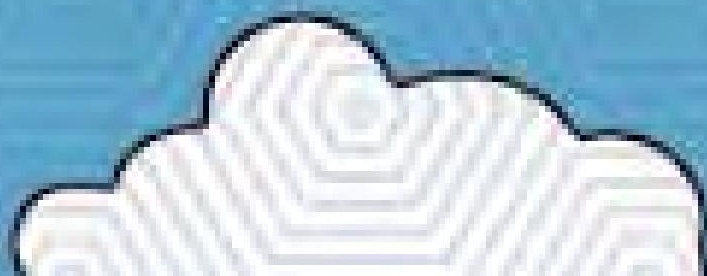


não corresponde ao estado do Tocantins, mas ao imaginário do idealizador da obra que, por intermédio da intertextualidade com obras artísticas instaladas em cidades brasileiras como Brasilia e Rio de Janeiro, constrói sua visão da história do estado. Vejamos o trecho do "Poema do medo" de Thiago de França que fala sobre o assunto:

O meu medo de falar no

\section{Silveira}

é que ouvi dizer

que ele é um bruxo

de uma ordem milenar

tem olhos de labareda

e lança feitiços

com seu chicote.

$[\ldots]$ vai que ele me

lança uma praga

e eu viro uma

estátua mal feita

na Praça dos Girassóis

(FRANÇA, 2018, p. 100)

França escreve seus versos em primeira pessoa para representar grande parte da população dos primórdios de Palmas que temiam a oligarquia criada por Siqueira Campos, cujas histórias contadas oralmente mostram a figura de um coronel autoritário que criava suas próprias leis. Com humor, o enunciador faz uma referência às obras de arte da Praça dos Girassóis, relacionando sua existência ao seu "criador", a quem denomina "Silveira" que mais uma vez representa um mito "um bruxo/ de uma ordem milenar".

\section{Trânsitos Interdisciplinares em Artes}

Bárbara Tavares dos Santos, Liliane Scarpin S. Storniolo, Renata Patrícia da Silva (Organizadoras)

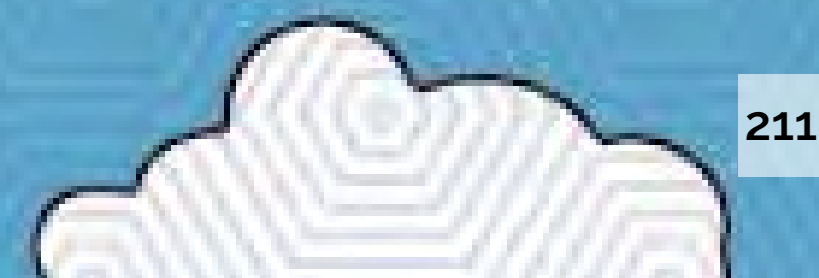


O enunciador diz temer ser transformado em uma "estátua mal feita/ na Praça dos Girassóis", visto que, as obras de arte que estão instaladas na praça são muito questionáveis do ponto de vista histórico e artístico, como veremos no decorrer do texto.

Para Silva (2008, p. 170) É necessário que prestemos atenção à "multiplicidade de referências entre as imagens e as metáforas que a paisagem entrelaça: cidades e temporalidades surgem estampadas na colcha de retalhos, costurada por fios imaginários, rendilhados entre memória e imaginação".

\section{Incentivo à cultura no governo Siqueira Campos}

Siqueira Campos sempre se cercou de estratégias para que seu discurso conseguisse a adesão de seus interlocutores, ou seja, para que o povo acreditasse em suas palavras. Uma das estratégias utilizadas por ele foi o incentivo à cultura, especialmente à música tocantinense. Um momento que pode ser destacado foi na posse do seu terceiro mandato, na qual, mais uma vez, contou com o apoio dos compositores locais. O periódico on-line "O coletivo"15 de $1^{\circ}$ de janeiro de 2011, veiculou a seguinte notícia:

Na manhã deste sábado, $1^{\circ}$, dezenas de artistas tocantinenses apresentaram o melhor da cultura local, durante o evento de posse do governador José Wilson Siqueira Campos. Os shows aconteceram em dois palcos montados na Praça dos Girassóis, em Palmas. Milhares de pessoas que estiveram presentes acompanharam vários estilos musicais e expressões artísticas que marcam o Estado, como a catira.

apoio de Siqueira aos artistas aparece nos discursos dos compositores que se apresentaram na ocasião e foram entrevistados pelo jornalista Samuel Daltan:

15 Jornal on-line "O coletivo", Disponivel em: <http://www.ocoletivo.com.br/noticia-656governador-siqueira-campos-recebe-homenagem-de-artistas-tocantinenses>, Acesso em: 24 abr. 2018

\section{Trânsitos Interdisciplinares em Artes}

Bárbara Tavares dos Santos, Liliane Scarpin S. Storniolo, Renata Patrícia da Silva (Organizadoras) 
O cantor e compositor Juraíldes da Cruz disse que acredita num bom momento para a cultura do Tocantins e que "o Estado está em boas mãos", se referindo ao início da gestão de Siqueira Campos. O também cantor e compositor Dorivan declarou: "estamos festejando o início d uma imagem e alguns versos com uma análise discursiva retomando as questões teóricas e um novo ciclo. A música tocantinense se sente homenageada hoje. o Governador é uma pessoa que tem comprometimento com a nossa cultura" [...]

A linguista Eni Orlandi (1999, p. 43) esclarece que "A formação discursiva se define como aquilo que numa formação ideológica dada - ou seja, a partir de uma posição dada em uma conjuntura sócio-histórica dada - determina o que pode e deve ser dito". Nota-se que Siqueira mantém sua posição ideológica pela conjuntura social e histórica que está inserido, porém. principalmente por sua posição política. Então, seu discurso é pautado pelo momento histórico que está acontecendo, no qual se coloca como centro, ou seja, como seu criador. O momento existe porque "ele" existe. Rodrigues (2008, p. 52) apresenta um trecho de um dos discursos de Siqueira pela emancipação do Tocantins no qual fala sobre

a continuidade de uma luta histórica feita por homens "heróicos" e que têm nele o último herdeiro com o dever de ir além de suas forças para criar o Estado do Tocantins, cujas áreas são "[...] belas e ricas planícies entrecortadas por cursos perenes de águas límpidas e por cordilheiras com grandes jazimentos minerais, conta com riquezas incalculáveis".

Verifica-se que, com o passar do tempo, o tom do discurso tornou-se menos ácido, porém mais focalizado na personagem heroica do mito fundador do Tocantins, que agora não é mais Teotônio Segurado, mas Siqueira que se coloca como herdeiro da missão de "construir" o Tocantins.

Em 31 de dezembro de 2002, houve a criação da Lei no 1.367. que institui o canto "Hino ao Tocantins", letra e música de autoria do compositor Genésio Tocantins Sampaio Filho, como

\section{Trânsitos Interdisciplinares em Artes}


canção-símbolo do estado. Essa canção marcou o $14^{\circ}$ aniversário da criação do estado, cujo governo estava pela terceira vez sob o comando de Siqueira Campos e ficou mais conhecido do que o hino oficial instituido pela lei estadual n 977, de 30 de abril de 1998.

Coração, ouro verde, vida, paz...

Labor, conquista, união

Construir, crescer, preservar

Essa terra nossa nação

Sonho vivo, nativo real,

Memória, nossos heróis

Pais, filhos, história,

Familia ideal

Tocantins, Tocantins...

Gente forte, fé no porvir..

Tocantins, Tocantins...

Liberdade, trabalho, amor...

O enunciador empresta suas palavras para o discurso do governo vigente. Aparece mais uma vez o paraíso descrito por suas belezas naturais, mas, além disso, surge um o sentimento de pertencimento ao lugar, uma calmaria expressa pela palavra "paz" (Coração, ouro verde, vida, paz/ Matas, rios, vales, serras, cerrados/ Minerais, pomar Amazônia/ Fauna, flora, grão semeados). É descrito o heroísmo e os personagens que representam os primeiros (pioneiros) habitantes do Tocantins, alusão à escultura do artista plástico Maurício Bentes (imagem 33) que está na praça dos Girassóis, na capital Palmas (pais, filhos, história, a familia ideal).

Podemos verificar, como já comentamos anteriormente, que o monumento retrata a família de Siqueira Campos como representantes do sofrimento do povo tocantinense, o agradecimento pela conquista do estado e a religiosidade. Em seguida, na letra da canção, o enunciador exalta a força do povo tocantinense e seu amor pelo estado (Gente forte, fé no porvir/ Liberdade, trabalho, amor) e seu futuro promissor (Crianças, pão, escola) e finalmente, expõe a cultura e a tradição. Mais uma vez aparece a representação da "terra prometida".

\section{Trânsitos Interdisciplinares em Artes}

Bárbara Tavares dos Santos, Liliane Scarpin S. Storniolo, Renata Patrícia da Silva (Organizadoras)
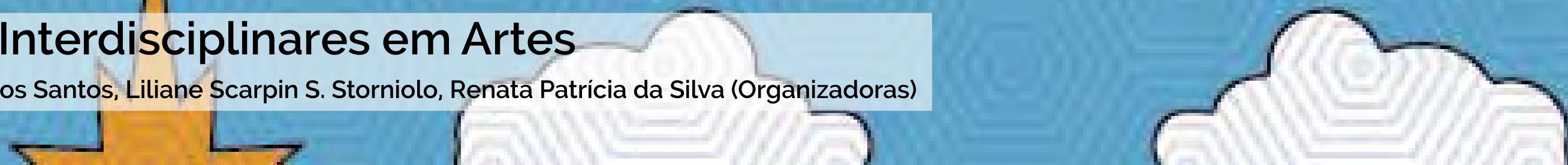


\section{Considerações Finais}

A trajetória da criação do estado do Tocantins procura apresentar a construção da identidade de uma região que. supostamente, por muitos anos, foi preterida pelos governos que estavam situados nas regiões sul e sudeste do Brasil. Como pudemos constatar, a identidade não é apenas composta por um elemento, mas gerada a partir de um contexto sócio-histórico e a partir da relação de pertencimento que os sujeitos desenvolvem sobre o espaço territorial que habitam, ou seja, sua identidade territorial. No decorrer do texto analisamos o processo de ocupação da região norte do estado de Goiás que teria passado por momentos de desesperança, mas também de superação dos problemas apresentados pela ausência de apoio do governo Federal que destinava seu apoio, especialmente financeiro, a então comarca do Sul.

A história oficial do Tocantins retrata lutas destinadas à separação da região norte de Goiás e, consequentemente a criação do Tocantins. Para que a história fosse contada, resgatou-se um dos mitos fundadores do estado. O mito fundador, nessa perspectiva, confunde a história do povo tocantinense com a história de vida de Wilson Siqueira Campos.

\section{Trânsitos Interdisciplinares em Artes}

Bárbara Tavares dos Santos, Liliane Scarpin S. Storniolo, Renata Patrícia da Silva (Organizadoras) 


\section{Referências}

ALBUQUERQUE JÚNIOR, Durval Muniz. A Invenção do Nordeste e outras artes. 2 ed.- Recife: FJN. Ed. Massagana; São Paulo: Cortez, 2001.

\section{CAMPOS, Siqueira. Siqueira mostra pedra misteriosa e conta fatos sobre a} criação de Palmas. Entrevista concedida a Sidney Neto. TV Anhamguera, 20/ Mai./2016. Disponivel em: http://g1.globo.com/to/tocantins/noticia/2016/05/ siqueira-mostra-pedra-misteriosa-e-conta-fatos-sobre-criacao-de-palmas. html, Acesso em: 3 ago. 2016.

FRANÇA, Thiago Ramos de. Palmacética. São Paulo: Soul, 2018.

HOBSBAWM, Éric: RANGER, Terence. A invenção das tradições. São Paulo: Paz e Terra, 2008

MACIEL, Maria Eunice. Os sabores do patrimônio histórico. In: FILHO, M. F. L.; BEZERRA, M. (Org). Os caminhos do patrimônio no Brasil. Goiânia: Alternativa, 2006. p. 89-104

OLIVEIRA, José Manoel Miranda de. Estratégias separatistas e ordenamento territorial: a criação de Palmas na consolidação do estado do TocantinsUberlândia, Tese (Doutorado em Geografia) - Universidade Federal de Uberlândia, 2012. 297p. Disponivel em:< https://repositorio.ufu.br/ bitstream/123456789/15955/1/t.pdf>, Acesso em: 3 ago. 2018.
RODRIGUES, Jean Carlos. Estado do Tocantins: politica e religião na construção do espaço de representação tocantinense. Tese de doutorado apresentada ao Conselho de Pós-Graduação do Programa de Pós-Graduação em Geografia da Faculdade de Ciência e Tecnologia (FCT) da Universidade Estadual Paulista (UNESP), campus de Presidente Prudente (SP) 2008, 148p.. Disponivel em: <http://www2.fct.unesp.br/pos/geo/dis_teses/08/jeancarlosrodrigues.pdf>. Acesso em: 2 abr 2018

RODRIGUES, Jean Carlos. "O tocantinense não é goiano": a identidade regional e a criação do estado do Tocantins. Revista Espaço \& Geografia, Vol. 15, n² 2 . 2012. pp. 475-490

SANTAELLA, Lúcia. 0 que é semiótica. Coleção Primeiros Passos. São Paulo: Brasiliense, 1998.

\section{Trânsitos Interdisciplinares em Artes}

Bárbara Tavares dos Santos, Liliane Scarpin S. Storniolo, Renata Patrícia da Silva (Organizadoras) 


$$
\text { Fet }
$$




\section{A Criação Artística em Camus: Estética e Poética Absurdas}

José Soares das Chagas ${ }^{1}$ Alessandro Rodrigues Pimenta² Maria José de Pinho

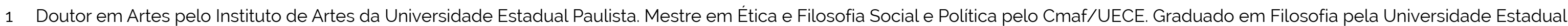

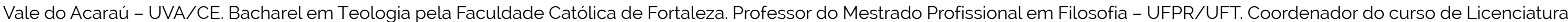

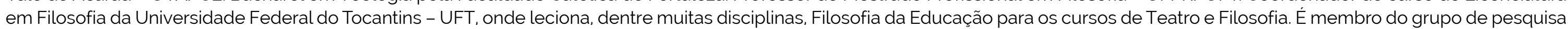

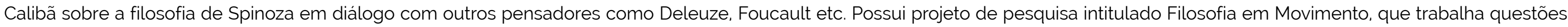
estéticas, éticas e metafísicas em diversas obras e pensadores, e-mail: jsoares007@hotmail.com.

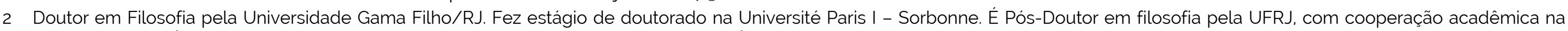

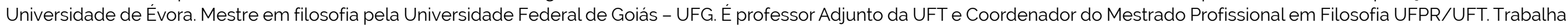
Arte e Educação na educação do campo. É avaliador de cursos de graduação pelo INEP/MEC desde 2010.

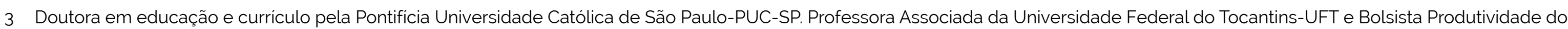
CNPQ categoria 02. Orienta mestrado e doutorado sobre formação de professores.

\section{Trânsitos Interdisciplinares em Artes}

Bárbara Tavares dos Santos, Liliane Scarpin S. Storniolo, Renata Patricia da Silva (Organizadoras)

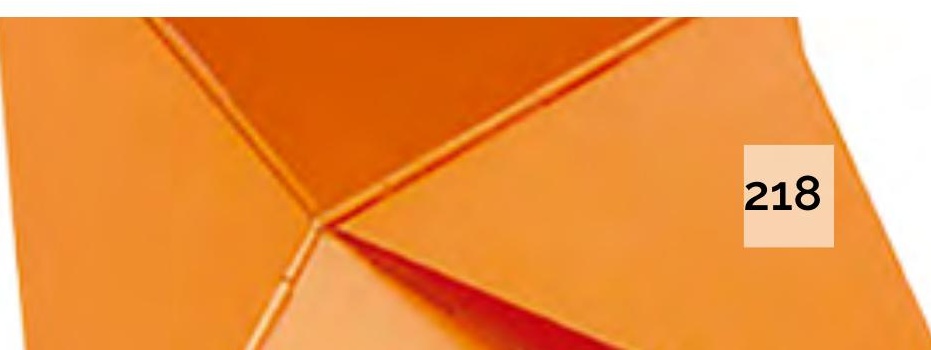


Efetivamente, sobre o quê e sobre quem posso dizer: "Eu conheço isto!"? Este coração que há em mim, posso senti-lo e julgo que ele existe. O mundo, posso tocá-lo e também julgo que ele existe. Ai se detém toda a minha ciência, o resto é construção. Pois quando tento captar este eu no qual me asseguro, quando tento defini-lo e resumi-lo, ele é apenas água que escorre entre meus dedos. Posso desenhar, um por um, todos os rostos que ele costuma assumir, todos também que lhes foram dados, esta educação, esta origem, este ardor ou estes silêncios, esta grandeza ou esta baixeza. Mas não se somam os rostos: este coração que é o meu permanecerá indefinivel para sempre. [...] Em psicologia, tanto quanto em lógica, há verdades, não uma verdade. O "conhece-te a ti mesmo" de Sócrates tem tanto valor quanto o "sê virtuoso" dos nossos confessionários. Revelam tanto uma nostalgia quanto uma ignorância. São jogos estéreis sobre grandes temas. Só são legítimos na medida exata em que são aproximativos (CAMUS, 2006, p. 33)
Este trabalho reflete a estética e a poética absurdas a partir da obra literária e filosófica do argelino Albert Camus. Partimos da compreensão da realidade dentro da aridez de sentindo e desilusões de finalidades, crenças e ideologias no quadro existencial que marca a vida no início da segunda metade do século XX para, em seguida, analisarmos como a arte em geral e os romances em particular traduzem e manifestam este conceito fundamental pelo qual a estética camusiana compreende o sentimento de sem sentido do homem moderno, a saber, o absurdo.

Camus pensa o absurdo como um ponto de partida existencial, como um sentimento dentro de uma experiência fundamental que exige uma tomada de atitude diante do mundo. É uma experiência que ocorre, inevitavelmente, no comum da vida e nos lança numa compreensão de nossa realidade sisífica.

Um certo dia sem nenhuma necessária áurea apoteótica ou epifânica nos defrontamos com o absurdo. Como uma ideia ou

\section{Trânsitos Interdisciplinares em Artes}


sensação que emerge no espírito de um artista. Às vezes tomando um simples chá (PROUST, 2006) - ou sentado em um boteco - vem um baque, nos desperta do sonho, nos diz que é hora de acordar e começar a viver. Camus (2014, p. 27), diz que podemos nos encontrar com o absurdo num belo dia, sem esperar, no dobrar da esquina. Ele nos surpreende como se desse um bofetão em nossa face. Isso não tem nada de místico. É apenas a carne saindo do seu torpor e se deparando com a vida fora dos seus sonhos e ilusões.

É o momento no qual os consolos metafísicos não são fortes o suficiente para nos impedir de sentir a aridez e o calor escaldante do deserto no qual vivemos. É o instante em que sentimos a nostalgia da unidade representada pela religião, pela filosofia ou pela ciência. É quando nos desesperamos, porque, embora acreditemos em algo, isso não é capaz de produzir convicção suficiente para nos livrar da lucidez da finitude, da precariedade e fracasso certo de tudo e de todos. É a vez em que despertos, sentimos nossa carne se rebelar e expressar o seu maior desejo: viver!
Nessa ocasião, afastado de sua rotina e lúcido perante sua condição, o individuo é tomado da única evidência de que o homem é capaz, a saber: o absurdo, que para Camus, no Mito de Sísifo, é o mesmo que a tensão entre esse desejo/apetite por explicação e o silêncio do mundo. É um apetite incontrolável, que o espírito tem de querer saber do mundo o seu sentido perante a opacidade da multiplicidade das coisas. Esse confronto e os sentimentos daí decorrentes, é o que podemos denominar absurdo. E o homem que não procura fugir nem anular esta primordial experiência é o que podemos chamar de homem absurdo, que encontra na criação artística a sua expressão e o seu campo mais fértil.

\section{O Absurdo e o Fazer Artístico}

Para Camus, a criação artística corresponde ao "ar avaro" (2014, p. 109) do homem absurdo. Assemelha-se a um tipo de conquista sem finalidade, a uma luta desigual na qual o individuo já sabe de antemão que, mais cedo ou mais tarde, irá ser superado.

\section{Trânsitos Interdisciplinares em Artes}


Porém, o que sustenta alguém na aridez da realidade nua da verdade? A resposta coerente a essa indagação só pode ser um pensamento profundo de fidelidade à evidência da carne. Saber que aquele que vive na guerra, na guerra morrerá (como certo adágio afirma) não é motivo para a infelicidade. Com efeito, o mesmo remédio que pode matar (se valendo mais uma vez de um provérbio) é o mesmo que produz a cura. E. nesse caso, tratase de não anular a evidência de que, inocentemente, vivemos condenados a uma comédia humana ou a uma miséria.

O sentimento de dignidade é o que produz a única felicidade possivel, a saber, a sensivel. Manter a consciência da batalha de uma guerra inútil é lutar contra a humilhação da deserção ou de uma vida motivada por aquilo que é contrário à carne: os fantasmas da esperança. Como assevera Camus: "Homens conscientes foram vistos cumprindo sua tarefa em meio às guerras mais estúpidas sem por isso se considerarem em contradição" (CAMUS, 2014, p. 109). No meio dessa batalha, em que os sentidos e as justificativas passam por cima da paixão de viver e de amar dos individuos, a lucidez do homem absurdo o impede de soerguer bandeiras e homenagens àquilo mesmo que o humilha.

Não quer a guerra, não a provocou e não teve a opção de não lutar. Entretanto, sem nenhuma outra alternativa, luta contra a humilhação da rendição e do espírito mesquinho e doente. A sua luta é, então, uma homenagem à dignidade humana, marcada inelutavelmente pela finitude e a certeza da derrota: a morte. É nesse sentido que no interior do pensamento absurdo o deleite e os afetos provocados pela arte representam a única via para aquele que não quer negar a vida nem pela sua renúncia (suicídio), nem pela exaltação daquilo que humilha (filosofias da transcendência). Como diz Nietzsche, "A arte e nada mais do que a arte. [...] temos a arte para não morrer ante a verdade" (CAMUS, 2014, p. 109).

A descoberta do absurdo é, ao mesmo tempo, o encontro com uma existência gratuita, submersa na falta de fundamento racionalizável. A obra de arte corresponde a esse universo em que a explicação é secundária, pois se trata de sentir, vivenciar e imitar. Mesmo que essa imitação não seja fotográfica. Melhor que

\section{Trânsitos Interdisciplinares em Artes}


não seja, inclusive. Porque se o fosse, assemelhar-se-ia mais a uma tentativa de representação "reflexiva" do que de uma multiplicação dos temas e fazeres da arte, cuja profundidade encontra o nada. Quem cria, artisticamente, não só participa do absurdo com o seu movimento de produção de afetos, como também contribui na manutenção da consciência lúcida do silêncio do mundo. "Nesse universo, a obra é então a oportunidade única de manter sua consciência e de fixar suas aventuras. Criar é viver duas vezes" (CAMUS, 2014, p. 110).

O artista encontra seu deleite na criação contínua do mundo que, não oferecendo unidade confiável, abre espaço para recriação da realidade: cuja verdade não é outra coisa senão as verdades das várias imitações plasmadas numa obra, em que o espírito do criador absurdo é a própria essência do devir captado no seu presente. $O$ artista cria segundo o afeto do sentimento absurdo, pondo no mundo sua intenção e vida, num encontro sem finalidade de criação e gozo desinteressado. Cria, pondo significados no criado e, concomitantemente, recria-se, já que no exercício de seu mister vai adquirindo as características das verdades que produz e que expressam, cada uma ao seu modo, o estado complexo de ânimo advindo do absurdo. Pois, "até mesmo os homens sem evangelho têm o seu Monte das Oliveiras. E neste, tampouco devem adormecer" (CAMUS, 2014, p. 110).

Depois da experiência de se deparar com o absurdo, num momento qualquer da vida em que se sentiu suspenso da vida maquinal, percebendo a (des)razão das agitações cotidianas, o indivíduo é lançado no vórtice de uma lucidez sobre o devir sem fim. Diante disso, é invitado pelo próprio absurdo a permanecer e firmar nesse campo a única liberdade e felicidade possivel: a de imitar e recriar a realidade, transformando a tensão entre o mundo e a consciência numa paixão pela vida e pelo trágico.

Ao mesmo tempo, sua única força é a criação contínua e inapreciável à qual se entregam, todos os dias de sua vida, o comediante, o conquistador e todos os homens absurdos. Todos tentam imitar, repetir e recriar sua própria realidade. Sempre acabamos adquirindo o

\section{Trânsitos Interdisciplinares em Artes}


rosto das nossas verdades. A existência inteira, para um homem afastado do eterno, não passa de uma imitação desmesurada sob a máscara do absurdo. A criação é o grande imitador (CAMUS, 2014, p. 110).

Vemos, portanto, que a arte 4 não é mero entretenimento. Não serve apenas para divertir e tornarem amenas as horas

4 Dentro de um ponto de vista contemporâneo, a arte é um processo afetivo-produtivo que pressupõe e se constrói em sua inteireza mediante sua fusão hermenêutica entre o artista e o público, no "coeficiente artístico" ou naquilo que se descobre por meio da participação ativa da interpretação do público na obra do artista: "Por conseguinte quando eu me referir ao "coeficiente artístico", deverá ficar entendido que não me refiro somente à grande arte, mas que estou tentando descrever o mecanismo subjetivo que produz arte em estado bruto - l'état brut - ruim, boa ou indiferente. No ato criador, o artista passa da intenção à realização, através de uma cadeia de reações totalmente subjetivas. Sua luta pela realização é uma série de esforços, sofrimentos, satisfações, recusas, decisões que também não podem e não devem ser totalmente conscientes, pelo menos no plano estético. [...] por conseguinte, na cadeia de reações que acompanha o ato criador falta um elo [...]; esta diferença entre o que quis realizar e o que na verdade realizou é o "coeficiente artistico" pessoal contido na sua obra de arte" (DUCHAMP, 1986, p. 73). vagas. É contrário! As paixões, desencadeadas pelo sentimento de ausência de uma unidade racionalizável, determinam o ponto de partida do ato criador, cujo trabalho é de sentir e fazer sentir pela descrição de afetos por meios diversos não discursivos - a repetição e o ciclo da vida no seu fluxo. Desse modo, a obra de arte representa a morte e a vida ao mesmo tempo, uma vez que parte de uma experiência afetiva acerca de alguma imagem, tema ou som e o multiplica em expressões diversas que, por sua vez, também tem o condão de provocar outros afetos.

O ato criador, por isso mesmo, é motivado pela emoção advinda da descoberta das diferentes e virtuais facetas da realidade, que não explicam e nem resolvem nada, mas que exploram e revelam um mundo de potência inesgotável em quantidade. "Agora se entende o lugar que ocupa a obra de arte" (CAMUS, 2014, p. 111).

\section{Trânsitos Interdisciplinares em Artes}


O fazer artístico é uma forma de conhecimento da realidade 5 que não explica nada. Procura sempre dizer menos, no sentido de que não se dispõe a resolver ou solucionar o problema do mundo, quando esse na verdade se reduz ao silêncio diante da razão inquiridora. Trata-se de um aprendizado que está no âmbito mais do savoir-vivre do que do savoir-faire (Cf. CAMUS, 2014, p. 113), quer dizer: entende-se mais como um conhecimento que não está preocupado em explicar, mas em apenas aprender a lidar com as sensações e as aparências, cobrindo de imagens aquilo que a razão não responde. "Se o mundo fosse claro, não existiria a arte" (CAMUS, 2014, p. 114).

Nesse sentido, a arte se abstém de dizer, de construir arrazoados, de multiplicar palavras em silogismos e na construção

5 Ao longo da história no mundo do ensino escolar, a arte assumiu facetas diferentes. Assim, nos séculos XVII-XIX, foi tratada como saber técnico, no século XX, como expressão ou como atividade (no caso do período da ditadura); e, atualmente, é vista dentro de um âmbito que envolve toda a vida humana em sociedade, a saber: como cultura. Dentro deste contexto, destaca-se a arte como um lugar transdisciplinar e transmetodológico, que afeta o ser humano integralmente, bem como todas as suas expressões simbólicas (Cf. COUTINHO; SCHLÜNZEN JUNIOR; SCHÜLUZEN, 2013). de sistemas lógico-interpretativos. Ao contrário, a obra de arte evidencia o próprio absurdo ao nos libertar dos fantasmas das explicações, dos sentidos prontos ou ditos de um outro modo: daquilo que não se faz sentir na carne, no corpo pulsante de afetos e ideias. "Quero libertar o meu universo de seus fantasmas e povoálo apenas com verdades de carne cuja presença não possa negar" (CAMUS, 2014, pp. 116-117).

Essa libertação da necessidade de tudo explicar e de nada ou pouco sentir, esse suporte de carne dado às ideias, nessa consciência lúcida de que o mundo e os seus significados são apenas potências de criação de um universo, que é o próprio absurdo em movimento. Por isso, o ato criador do artista é uma ação que abraça o tempo e o precário, pois sabe que cria do nada e para o nada, configurando-se mais como o processo de produção de afetos, fadados a se consumirem na própria experiência do encontro, do que como uma obra acabada, mesmo em se tratando de um exemplar de virtuosismo e genialidade.

\section{Trânsitos Interdisciplinares em Artes}


Fruto de um pensamento profundo de desrazão do mundo e da razão humilhada, a atitude criadora não só é capaz de educar os sentidos, como é capaz de libertar o artista de sua genialidade. E isso porque o segredo do caráter comovente dos produtos artísticos não está em nenhum mistério de caráter transcendente das habilidades dos artistas, mas está exatamente na sua própria presença-ausência na obra.

Ora, ao conhecer a obra de uma artista, podemos enxergar toda a sua vida em tentativas justapostas em trabalhos, porém também vemos ações, cujo fim se esgota no próprio ato e que, ao entrar em contato com o público, se refaz a partir do material da própria vida de quem se permite compor com os artefatos ou sons propostos. Enfim, a atitude criadora se entende muito melhor por meio de um pensamento negativo, como afirma Camus. Esse entendido não como pessimismo, mas como um modo de deixar em aberto aos diversos sentidos, aquilo que nasceu de um sentimento absurdo de falta de um sentido satisfatório universal e fechado.
É por esse motivo que a criação artística é mais um aprendizado do aprender a viver no meio absurdo que um saber fazer ou produzir artefatos. No fundo, o artista é um artesão que vai aprendendo e ensinando com suas obras que as ações, embora almejem a eternidade, vivem no tempo e são fadadas à finitude. É como um "esculpir na argila".

Nada serve tão bem à arte quanto um pensamento negativo. Seus procedimentos obscuros e humilhados são tão necessários para se entender uma grande obra quanto o negro é para o branco. Trabalhar e criar "para nada", esculpir na argila, saber que sua criação não tem futuro. ver essa obra ser destruída em um dia, estando consciente de que, no fundo, isso não tem mais importância que construir para os séculos, eis a dificil sabedoria que autoriza o pensamento absurdo. Desenvolver ambas as tarefas ao mesmo tempo, negar por um lado e exaltar pelo outro é o caminho que se abre diante do criador absurdo. Ele deve dar suas cores ao vazio. [...] tudo isso "para nada", para

\section{Trânsitos Interdisciplinares em Artes}


repetir e marcar o passo. Mas talvez a grande obra de arte tenha menos importância em si mesma do que na prova que exige de um homem e a oportunidade que the oferece para superar seus fantasmas e se aproximar um pouco mais da sua realidade nua (CAMUS, 2014, pp. 130-131).

Porém, a essa altura de nossa reflexão, cabe indagarmos se toda obra de arte representa esse pensamento libertador das soluções a priori, transcendentes e consoladoras. Para Camus, o trabalho artístico em geral obedece a regra do absurdo na medida em que o artista, movido por sua intuição e imaginação, colocase um problema que, ao final, ele se nega a responder. Nas artes visuais vislumbra-se esse caráter nas tentativas sempre reiteradas de produzir técnicas capazes de resultar em efeitos de impressões de movimentos, cores e sensações em constantes atualizações. Vide os Bichos de Lygia Clark, que necessitavam da participação do público: ao interagir com a obra, ela é recriada e ganha novos sentidos.
Na música, vemos a valorização do som e da composição para além da harmonia, do virtuosismo e do purismo. Percebemos uma atenção maior no processo, na produção do som e na criação em si do que na obra acabada. A improvisação, a mistura de sons, a encenação do processo produtivo, a ênfase na necessidade da execução da proposta musical pelo público ou a ausência da autoria monologal é o que se percebe em compositores como Jonh Cage e Stockhausen (ECO, 2015. p. 65). E isso se estende também à polifonia presente em ritmos como jazz, o rock heavy metal, o rock progressivo, o rap, o hip hop, o repente nordestino, dentre outras manifestações musicais.

Em todas essas manifestações artísticas, vislumbramos uma manifestação de uma arte absurda ou de uma produção que "diz menos" (CAMUS, 2014, p. 113), que não procura resolver, tornar-se um fim ou oferecer um sentido para o público, pois sua atividade produtiva pressupõe que a arte "[...] não pode ser o fim, o sentido e

\section{Trânsitos Interdisciplinares em Artes}


o consolo de uma vida. [...] O criador absurdo não se apega à sua obra" (CAMUS, 2014, p. 113). Quer dizer: imbuido do espírito absurdo, o artista é capaz de abrir mão não só da interpretação dada a sua obra, mas até mesmo, às vezes, da própria autoria em relação ao público.

\section{O Absurdo e a Criação Literária}

No caso da literatura, merecem destaque os romances, pois neles a tentação de explicar e resolver é maior. Camus destaca dois tipos desse gênero, a saber: os romances absurdos e os romances de tese. Os chamados romances de tese caracterizamse por se afastarem da intuição criadora inicial, cuja evidência é o divórcio entre a consciência e o mundo, a incapacidade da razão alcançar uma unidade satisfatória para essa cisão entre os anseios inerentes ao individuo e a miséria na qual ele se encontra inevitavelmente. Esse tipo de produção artística, ao invés de despertar da ilusão de um sentido único e se lançar na multiplicidade e diversidade, cai na tentação do princípio explicador.

Dessa forma, ao escrever, apenas narra a ilustração de uma tese que pretende demonstrar com uma história. Enfim, o escritor é até lúcido ao colocar o problema das contradições, das des-razões e das agitações nas quais nos encontramos, porém não se abstém de dar uma solução, de resolver o problema para o leitor. Por isso, esse tipo de literatura acaba por se tornar mais um meio de consolo ou um entretenimento, que nos convence de uma verdade e nos afasta do ar avaro do absurdo.

O romance filosófico, ao contrário do de tese, caracterizase por não se assustar com as condições adversas compreendidas por meio do sentimento absurdo. Camus cita alguns escritores como exemplo: "[...] Balzac, Sade, Melville, Stendhal, Dostoievski, Proust, Malraux, Kafka entre outros" (CAMUS, 2014, p.116). Todos esses autores rejeitam o princípio explicativo como condutor de

\section{Trânsitos Interdisciplinares em Artes}


suas narrativas. Os seus escritos denotam a descrença em uma razão potente capaz de sanar a absurdidade do mundo e a crença na "mensagem instrutiva da aparência sensivel" (CAMUS, 2014. p. 116).

Destaca-se no romance filosófico um caráter de abertura da poética empregada, de maneira que a evidenciação do absurdo e a postulação do problema da narrativa se configuram mais como um convite a um mergulho e a uma fruição do ambiente e do clima produzido do que a uma proposta de abrigo ao "mal" do mundo ou a um consolo pela inutilidade das ações empregadas. Esses romancistas colocam sempre em seus textos um problema ao qual, no final, isentam-se de responder ou solucionar. O caráter redentor desaparece ou, pelo menos, perde a relevância no desfecho.

No entanto, nesse gênero artístico, quiçá por conta do seu caráter congênere ao discursivo e aos raciocínios, facilmente declina-se para às explicações e justificação do porquê de tudo dispor-se assim como conhecemos. Em vez de acompanhar o próprio movimento das aparências sensiveis e apenas descrevê-las ou figurá-las das mais diversas formas, os romancistas tendem a apelar para um sentido universal ou a uma ideia harmonizadora, cuja postulação serve como uma espécie de teodiceia ou uma razão que procura nos convencer de que, no todo da história, as dores e os sofrimentos dos justos valerão a pena; e também que os males que enxergamos nas diversas circunstâncias da vida e em vários acontecimentos são apenas movimentos singulares que contribuem com a harmonia do todo. Como um escritor constrói um mundo em seu romance, não é difícil tornar-se o porta-voz da onisciência e da sabedoria a guiar os rumos de tudo para o melhor. E assim o romance torna-se uma ilustração de uma moral ou assume um caráter redentor.

Para Camus, mesmo autores que intensamente incorporaram o absurdo a sua poética, muitas vezes, sucumbiram a

\section{Trânsitos Interdisciplinares em Artes}


necessidade de justificar os desencontros e as desrazões por meio de um sentido transcendente. Os grandes exemplos dessa literatura são Dostoiévski e Kafka. No caso do autor russo, percebese que a questão do absurdo é posta em primeiro plano, pois todas as personagens se questionam sobre as desrazões do mundo e da vida. Dostoiévski não teme o ridículo e cria suas personagens ilustrando uma questão fundamental, a saber, "A existência é enganosa ou é eterna" (CAMUS, 2014, p.117). A partir desse dilema, as vozes do romance multiplicam-se e chocam-se dentro de um estado de polifonia, ${ }^{6}$ em que não há uma predominância de uma

6 Segundo Mikhail Bakhtin Dostoievski é um artista inovador, pois cria um gênero literário em que a voz do narrador não se sobrepõe a das personagens. De maneira que querer reduzir a unidade dos romances a questões meramente ideológico-sociais ou psicológicas desvia a atenção ao processo artístico e poético singular: "Dostoiévski é o criador do romance polifônico. Criou um gênero romanesco essencialmente novo. Por isso, sua obra não cabe em nenhum limite, não se subordina em nenhum esquema histórico-literários que costumamos aplicar às manifestações do romance europeu. Suas obras marcam o surgimento de um herói cuja voz se estrutura do mesmo modo como se estrutura a voz do próprio autor no romance comum" (BAKHTIN, 2015, p. 5). em detrimento das outras. Todos procuram um remédio para a miséria humana seja nas sensações, seja no eterno. E, no fim das contas, o romance apenas ilustra o absurdo e não o resolve: não conclui?.

No entanto, diante de sua própria vida e das críticas que recebera, o russo recua - sobretudo em razão das personagens que encarnam o absurdo, haja vista Kirilov e o suicídio lógico e Ivan e a indiferença entre matar e deixar de viver. Diante do perigo desse pensamento altivo e afirmativo, Dostoiévski toma uma

7 Luiz Pondé, comentando Bakhtin, enfatiza o conceito de equipolência nos romances dostoievskianos como uma referência moderna de uma ideia que apareceu primeiramente na filosofia cética antiga do Sexto Empírico, em que se parte da ideia de uma realidade diante da qual todas as visões se equivalem. No caso da poética do Dostoiévski, isso equivale a um conjunto de vozes equivalentes e autônomas: "A ideia de vozes equipolentes significa um ruído de vozes contínuos e interminável; é por isso que, ao ler Dostoiévski, temos a sensação de que seus livros não acabam: tem-se a impressão de que, de repente, ele simplesmente "passa um facão" na história, senão o livro não acabaria nunca; ou ainda de que seus livros são mal organizados, de que não há uma relação orgânica entre suas partes" (PONDÉ, 2013 p. 140).

\section{Trânsitos Interdisciplinares em Artes}


posição contra suas criaturas/personagens. Em seu Diário, afirma contra Kirilov, que "A fé na imortalidade da alma é tão necessária para o ser humano (que sem ela acaba por se matar) [...]. Sendo assim, a imortalidade existe sem qualquer dúvida" (DOSTOIÉSVSKI In: CAMUS, 2014, pp. 124-125).

E nos Irmãos Karamázov, nas últimas páginas, narra a resposta de Aliôcha convicto de sua fé, a uma criança: "Com certeza nós nos encontraremos de novo e contaremos alegremente tudo o que nos aconteceu" (CAMUS, 2014, p. 125). Por essas razões, Dostoiévski deslinda o dilema intrincado de sua poética e responde às suas criaturas afirmando que "A existência é enganosa e eterna" (CAMUS, 2014, p. 127). Dessa forma, vê-se que esse romancista é apenas um existencialista, embora ponha a questão do absurdo. "Não se trata aqui de uma obra absurda, mas de uma obra que coloca o problema absurdo" (CAMUS, 2014, p. 126).
Também Kafka, na sua literatura repleta de absurdos, ${ }^{8}$ em que as personagens parecem heróis "[...] trêmulos e obstinados a perseguir problemas que eles nunca formularam" (CAMUS. 2014, pp. 145-146), postula uma redenção, uma esperança. $\bigcirc$ grito

8 Kafka escreve com uma linguagem conservadora, quase cartorial, para escrever sobre questões insólitas, sem permitir que elas sejam postas no campo das fábulas. Para isso, ele põe, como no caso da Metamorfose, o narrador com o foco no protagonista, sem dar-lhe a onisciência da consciência da personagem e da trama como um todo. Este recurso causa uma sensação de estranheza no leitor, que se vê também em uma metamorfose dentro de uma sociedade administrada: "Isso explica porque na obra de Kafka, principalmente em seus três romances, o narrador não onisciente, relata com a maior clareza histórias marcadas pela mais profunda ambiguidade. E é nesse passo que o leitor se descobre tão impotente quanto o herói para perceber com discernimento, e não apenas parceladamente, as coordenadas reais do mundo-fragmento em que ambos tateiam. No entanto é justamente essa estratégia artística que articula, no plano de construção formal, a consciência alienada do homem moderno, constrangido a percorrer às cegas os caminhos de uma sociedade administrada de alto a baixo, onde os homens estão concretamente separados não só uns dos outros como também de si mesmos" (CARONE, 2009, pp. 15-16).

\section{Trânsitos Interdisciplinares em Artes}


desesperado, que parece ficar entalado na garganta por causa do tamanho horror e das angustiantes situações desenhadas, página após página, encontra uma resposta que o autor não se eximiu de dar a si mesmo. O absurdo encontra lugar nesses escritos na descrição lógica e rigorosa com que são apresentadas as experiências mais inusitadas possiveis.

Há uma lucidez no desespero que torna tudo mais estranho e incrivelmente claro. É o caso de Samsa na Metamorfose (KAFKA, 2017a) que, ao ver-se transformar num inseto, preocupase apenas com o fato de que é um trabalhador e que por causa dessa mudança repentina no seu corpo poderá chegar atrasado ao emprego. O grau de abertura interpretativa por conta dessa linha que se estende em meio ao caos de imagens e situações é enorme, exatamente porque a obra deste romancista é simbólica. E o símbolo é sempre genérico e diz mais do que se pretende. cabendo ao "[...] artista só lhe restituir o movimento" (CAMUS, 2014. p. 145). É nesse sentido que a poética kafkiana segue sem dúvida os princípios de uma estética absurda.
Entretanto, Kafka parece não conseguir viver respirando apenas o ar avaro do absurdo e da lucidez em meio à loucura do mundo. O criador aqui, em dado momento da sua escritura sucumbe à esperança e à redenção, e, em vez de deixar o problema em aberto, resolve-o para si e para os outros. Segundo Camus, o movimento evolutivo da obra de Kafka segue uma lógica existencial semelhante ao de Kierkegaard, no qual é necessário ferir de morte a esperança terrena para dar lugar à esperança verdadeira (CAMUS, 2014, p. 154). E nesse caso, a redenção vem pela humildade ou humilhação e pela dignidade humana que tem que se ajoelhar diante do absurdo, divinizando-o e o encontrando no contrário daquilo que se espera de Deus: no ódio, na desrazão e na imoralidade.

A esperança terrena é o Processo (KAFKA, 2017b) em que, sem motivo algum aparente, o senhor $K$ é acusado de algo que nunca entende o que é. E segue num crescente de sem sentido até ser "morto como um cão". A esperança verdadeira aparece no Castelo, em que o senhor Ké nomeado agrimensor de uma aldeia

\section{Trânsitos Interdisciplinares em Artes}


e passa toda a sua vida buscando "a graça" de ser acolhido no Castelo, de maneira que abre mão da sua condição de estrangeiro e de sua moral em nome daquilo que o esmaga, mas que agora é o seu Deus e o seu sentido. Aqui, o criador/Kafka sucumbiu a explicação e resolveu o problema de sua obra, desfazendo o absurdo. Por isso, a sua obra é existencial à semelhança de filósofos como Kierkegaard. Ela não consegue manter-se na altura da atitude artística, na qual se vê melhor, mas na qual também se respira com mais dificuldade. Ao que tudo faz parecer, essa exaltação do trágico e da vida absurda só encontra-se de uma maneira clara e segura, segundo Camus, num artista como foi Nietzsche.

Este ponto de vista ficará mais claro se eu disser que o pensamento verdadeiramente desesperado se define justamente por critérios opostos e que a obra trágica poderia ser aquela que, uma vez descartada toda esperança futura, descrevesse a vida de um homem feliz. Quanto mais exaltante for a vida, mais absurda será a ideia de perdê-la. Talvez esse seja o segredo da aridez soberba que se respira na obra de Nietzsche. Nessa ordem de ideias, Nietzsche parece ter sido o único artista que chegou às consequências extremas de uma estética do Absurdo. pois sua última mensagem reside numa lucidez estéril e conquistadora e numa obstinada negação de todo consolo sobrenatural (CAMUS, 2014, p. 156. Grifos nossos)

Tendo a concepção de Nietzsche como um artista completo, Camus desenvolve uma poética assumindo o absurdo como inspiração estética, depois de uma fase na qual predominou o lirismo. Vemos essa guinada literária da Morte Feliz para o Estrangeiro. Nessa primeira obra, temos uma personagem, cujo nome Mersault soa semelhante ao da segunda. Meursault (Cf. SANTOS, 2009, p. 53). Em ambas temos o tema do assassinato, do mar, da sensualidade e do sol escaldante da Argélia. Inclusive, a própria designação das personagens remete a planos comuns dos textos. Mer-sault é composta da palavra mar em francês (Mèr) e Meur-sault é oriundo do termo assassinar (meurtre), de maneira que isso nos remete à questão que se põe no centro das atenções

\section{Trânsitos Interdisciplinares em Artes}


nos dois livros, ou melhor, nos põe em contato desde o início com o deflagrador das questões, sentimentos e problemas desenvolvidos ao longo das tramas.

Na Morte Feliz, o autor narra em terceira pessoa uma história que divide a obra em duas partes: I - A morte biológica; e II - A morte consciente. Na primeira parte, destaca-se o clímax da obra no encontro de Mersault com Zagreus, um homem rico que havia a um bom tempo perdido as duas pernas e vivia preparando-se para subtrair a sua própria vida. Por meio de Marthe, uma amante comum a ambos, o herói do romance passa a travar conversa com o rico coxo. O momento alto desse diálogo é sobre o tema da felicidade, em que Zagreus relaciona a riqueza material à possibilidade de produzir situações de desfrute de tudo de bom que a vida é capaz de oferecer. Coisa que na sua situação miserável não é possivel. Então, não encontra motivo de continuar vivendo, senão o medo do ato fatal.

A lição desse rico e deplorável homem ensinada para o jovem e saudável Mersault é a de que o mais importante não é que "tempo é dinheiro", todavia é o contrário: "dinheiro é tempo". Ou seja, ter tempo e aproveitá-lo bem é tudo o que se precisa para ser feliz. E, por isso, Mersault não poderia ser feliz, pois trabalha oito horas diariamente.

Como bom discipulo, Mersault abrevia a vida de quem havia the ofertado a mais importante lição de vida e segue para segunda parte da obra, na qual tendo tempo investe seu dinheiro em viagens, banhos de mar, de sol, caminhadas e na harmonização dos seus sentidos com a volúpia da natureza. O final dessa segunda parte (e do (ivro) é a descrição da morte feliz de Mersault numa visão final, em que, no leito de morte confunde a natureza avistada por meio da janela aberta com o corpo sensivel de Lucienne, sua amada. Desse modo, esse Mersault vive uma aventura que segue uma poética clássica, em que se respeita o arco narrativo e se apresenta uma mensagem de exaltação sensivel de harmonia com o mar, a terra, os corpos e todo o prazer sensivel decorrente dessas sensações.

Se a Morte Feliz, obra que Camus não quis publicar, não pode ser considerada absurda, diferentemente, O Estrangeiro

\section{Trânsitos Interdisciplinares em Artes}


assume as alturas do ar avaro da arte. À semelhança de Kafka, nessa obra o arco narrativo é quebrado ao se colocar o "ápice" no início e transformar tudo no desdobramento de um acontecimento que em si mesmo não tem justificativa plausivel: a morte da mãe. A partir de então, segue uma narrativa feita em primeira pessoa, dentro do gênero literário diário íntimo, em que a personagem parece reunir notas de lembranças em função de aliviar o tédio

Também em duas partes, o herói fala de suas desventuras apresentando as situações e suas impressões sem nenhum juizo de valor ou sem se perguntar pela importância de tudo o que the acontece. Não se questiona sobre o amor que tem pela mãe ou o que ela significava para ele. Não reflete sobre as razões de ter matado o árabe na praia, nem mesmo para defender-se alegando a legítima defesa. Apenas o que faz é descrever suas sensações e impressões, obedecendo certa cronologia não muito clara.

Quando é indagado sobre se amava sua mãe, ele simplesmente afirma que havia a mandado ao asilo por conta da sua condição financeira escassa, que o impossibilitava de cuidar dela; porém era certo que gostava. Quando perguntam no tribunal por que matara o árabe, sua resposta é "por causa do sol forte". Quando Marie the pergunta se ele quer casar. Meursault diz que se isso é importante para ela e, que sim, que podem contrair matrimônio. Porém, quando sua noiva the pergunta se ele a ama, ele simplesmente diz não entender bem isso e que não é certo que a ama.

Assim, o herói e narrador da história choca o leitor com uma sinceridade e um mistério, ${ }^{9}$ o qual esperamos que seja solucionado e que, porém, permanece em aberto. O Meursault seja

9 Em Sartre, há uma essência a ser construída, mas nunca dada e pronta, o que explica a sensação constante de náusea de Roquentin, já que não encontra no mundo nada senão pura gratuidade da existência. As coisas e o próprio homem estão sempre sobrando. "Sinto vontade de ir embora, de ir a algum lugar onde pudesse estar realmente em meu lugar, onde me encaixasse... Mas meu lugar não é em parte alguma; eu estou sobrando" (SARTRE, 2015, p. 139). Aqui, Sartre e O Estrangeiro se aproximam muito em seus significados estéticos e éticos, já que este respeita a multiplicidade de individualidades a partir de sua poética aberta; e aquele concebe o homem como angústia, uma vez que tem a infinita liberdade e responsabilidade por tudo aquilo que faz.

\section{Trânsitos Interdisciplinares em Artes}


pelas suas atitudes que contrastam com os hábitos e expectativas sociais, seja pela opção de escrita inovadora na literatura francesa, produz uma obra em que o problema do divórcio do homem com o mundo é posto, mas em nenhum momento é resolvido. Camus resiste ao princípio de explicação e deixa o seu romance sem redenção. É isso o que entende, por exemplo, Sartre que. ao comentar O Estrangeiro, destaca esses aspectos que aqui colocamos. Sobre a questão das convenções, como o valor do sentimento do amor, comenta o existencialista francês:

O que chamamos de sentimento é apenas a unidade abstrata e a significação de impressões descontínuas. Não penso sempre naqueles que amo, mas afirmo que os amo mesmo quando não penso nisso - e seria capaz de comprometer minha tranquilidade em nome de um sentimento abstrato, na ausência de toda emoção real e instantânea. Meursault pensa e age diferentemente: não quer conhecer estes grandes sentimentos contínuos e todos iguais; para ele o amor não existe, nem mesmo os amores. Só o presente conta, o concreto. Ele vai ver sua mãe quando tem vontade, eis tudo. Se tal vontade the ocorre, será suficiente forte para fazê-lo tomar o ônibus, visto que essa outra vontade concreta terá força suficiente para fazer esse indolente correr a todo vapor e saltar num caminhão em marcha. Ademais, ele sempre denomina sua mãe terna e infantilmente como "mamãe" e não perde uma ocasião de compreendê-la e de identificar-se com ela (SARTRE, 2005, p. 123)

E quanto à questão da poética empregada n'O Estrangeiro, Sartre destaca o uso do passé composé e da ausência de uma ordem diferente do tempo cronológico.

Agora compreendemos melhor o talhe de sua narrativa: cada frase é um presente. [...] A frase é precisa, sem arestas, fechada em si mesma; é separada da frase seguinte por um nada [...]. Entre cada frase e a seguinte o mundo se aniquila e renasce: a fala tão logo vem à tona, é uma criação ex nihilo: uma frase d'O Estrangeiro é uma ilha. E caímos em cascata de frase em frase, de nada em nada. Foi para acentuar a solidão de cada unidade frasal que

\section{Trânsitos Interdisciplinares em Artes}


Camus escolheu construir sua narrativa no pretérito perfeito composto. [...] "/l s'est promené longtemps" dissimula a verbalidade do verbo. O verbo é rompido, quebrado em dois: de um lado encontramos um participio passado que perdeu toda a transcendência, inerte como uma coisa, e de outro o verbo être, que tem apenas o sentido de uma cópula que liga o particípio ao substantivo como o atributo ao sujeito. O caráter transitivo do verbo se desvaneceu, a frase se congelou; sua realidade agora é o nome (SARTRE, 2005, p. 130)

Assim, n'O Estrangeiro Camus desenvolve uma poética em que o absurdo não é só posto, como se torna a própria condição de construção do romance. Nesse ponto, o escritor franco-argelino é um artista como Nietzsche, pois a sua obra não sucumbe ao desejo de explicar e resolver. Como diz Barthes, nesse romance encontramos um tipo de escrita em que, pela primeira vez na literatura francesa se desenvolve uma "fala transparente" (BARTHES, 1972, p. 161) ou um modo de escrever e narrar no qual o autor não age como se fosse um demiurgo procurando estabelecer uma causalidade teleológica a todas as ações que ocorrem.

A motivação moral ou ideológica do escritor está presente na obra, mas não como o fio condutor. Pois, o que guia a trama é aquilo que o uso do passé composé produz, a saber, uma junção de acontecimentos em torno de uma personagem narradora que experimenta a gratuidade dos acontecimentos da vida e respira o seu ar avaro. Deixando de lado o tempo verbal dos autores clássicos franceses (passé simples), Camus então faz da arte um caminho sem um destino único, sem transcendência ao texto.

Ao contrário do que ocorre em Kafka e Dostoiévski, o absurdo não é abandonado: não há redenção. Dessa forma, ao final do romance, enquanto aguarda a pena de morte, Meursault não se sente menos condenado e inocente do que nós que estamos aqui fora da cela. E, por isso, rechaça as investidas da esperança e consolo do cura, que the quer dar razões de crença de uma outra vida. Sua resposta a ele - sobre se já havia imaginado uma outra

\section{Trânsitos Interdisciplinares em Artes}


vida e como seria o paraíso na sua concepção, se existisse - ilustra muito bem o ethos do absurdo: "Uma vida na qual eu pudesse lembrar desta vida" (CAMUS, 2015, p. 123).

Para Meursault, toda a fé e a esperança do padre não valiam nem um pouco da sua consideração. "[...] nenhuma de suas certezas valia um cabelo de mulher. Nem sequer tinha certeza de estar vivo, já que era um morto (CAMUS, 2015, p. 124). E assim liberado da esperança, Meursault se sente mais próximo da única liberdade e felicidade possiveis: a sensivel. De maneira que a obra termina sem uma redenção e sem sucumbir ao princípio de explicação. Mantém-se o divórcio entre o desejo de unidade do espírito humano, de um lado, e o silêncio, a contingência e a gratuidade do mundo, de outro lado. Trata-se, sem dúvida, de uma obra maximamente aberta ou de uma poética e uma estética absurdas, na qual os consolos transcendentes são postos à margem em nome do ar avaro da lucidez e da vida pulsante da carne.

\section{Referências Biliográficas}

CAMUS, Albert. Théâtre, Récits, Nouvelles. Paris: Gallimard, 1962.

CAMUS, Albert. Caligula. Théâtre, Récits, Nouvelles. Paris: Gallimard, 1962a. CAMUS, Albert. L'Étranger. Théâtre, Récits, Nouvelles. Paris: Gallimard, 1962b. CAMUS, Albert. La Peste. Théâtre, Récits, Nouvelles. Paris: Gallimard, 1962C. CAMUS, Albert. L'Exil et le royaume. Théâtre, Récits, Nouvelles. Paris: Gallimard, 1962d.

CAMUS, Albert. Textes complémentaire. Théâtre, Récits, Nouvelles. Paris: Gallimard, 1962e.

CAMUS, Albert. Essais. Paris: Gallimard, 1965

CAMUS, Albert. L'envers et l'endroit. Essais. Paris: Gallimard, 1965a. CAMUS, Albert. Le mythe de Sisyphe. Essais. Paris: Gallimard, 1965b. CAMUS, Albert. L'homme révolté. Essais. Paris: Gallimard, 1965C. CAMUS, Albert. Discours de Suède. Essais. Paris: Gallimard, 1965d. CAMUS, Albert. Textes complémentaire. Essais. Paris: Gallimard, 1965e. CAMUS, Albert. A morte Feliz. Trad. Valerie Rumjanek. São Paulo: 1971. CAMUS, Albert. Discurso da Suécia. Trad. Sousa Vitorino, Lisboa: Livros do Brasil, 1983.

\section{Trânsitos Interdisciplinares em Artes}


CAMUS, Albert. o exilio e o reino: Jonas ou o artista trabalhando. $6^{\mathrm{a}}$ ed. Trad. Valerie Rumjanek, São Paulo: Record, 1997.

CAMUS, Albert. The rebel. Translated by Anthony Bower. London: Peguins books, 2000.

CAMUS, Albert. El hombre rebelde. Traducción de Luis Echávarri, Buenos Aires: Losada, 2003

CAMUS, Albert. A Peste. $16^{a}$ ed. Trad. Valerie Rumjanek, São Paulo: Record. 2006.

CAMUS, Albert. 0 avesso e o direito. $7^{\mathrm{a}}$ ed. Trad. Valerie Rumjanek, São Paulo: Record, 2013.

CAMUS, Albert. 0 mito de Sísifo. $11^{\mathrm{a} e d}$. Trad. Roitman e Paulina Watch. São Paulo: Record, 2014.

CAMUS, Albert. 0 estrangeiro. $37^{\mathrm{a}}$ ed. Trad. Valerie Rumjanek. São Paulo: Record, 2015.

CAMUS, Albert. Caligula. Trad. Javier Albiñana. Paris: edición en formato digital: 2015. (Kobo)

CAMUS, Albert. o homem revoltado. Vol. 1, $2^{\mathrm{a}}$ ed. Trad. Valerie Rumjanek, Rio de Janeiro: BestBolso, 2017.

BAKHTIN. Mikhail. Problemas da poética de Dostoiévski. $5^{\mathrm{a}}$ ed. Trad. Paulo Bezerra. Rio de Janeiro: Forense Universitária, 2015.
BARTHES, Roland. 0 grau zero da escritura. $2^{a}$ ed. Trad. Heloysa de Lima dantas, Anne Arnichand e Álvaro Lorencini. São Paulo: Cultrix, 1972.

CARONE, Modesto. Lição de Kafka. São Paulo: Companhia das Letras, 2009. COUTINHO, Rejane; SCHLÜNZEN JUNIOR, Klaus; SCHÜLUZEN, Elisa Tomoe (Org.). Artes. São Paulo: NED, 2013. (Temas de Formação).

DOSTOIÉVSKI, Fiódor. Os demônios. Trad. Paulo Bezerra. São Paulo: editora 34. 2013

DOSTOIÉVSKI, Fiódor. O idiota. Trad. Paulo Bezerra. São Paulo: editora 34, 2012. DOSTOIÉVSKI, Fiódor. Os irmãos Karamázov. Vol. 2. Trad. Paulo Bezerra, São Paulo: editora 34, 2012.

DUCHAMP, Marcel. "O ato criador". In: BATTCOCK, Gregory. A nova arte. Trad. Cecília Prada e Vera de Campos. $2^{a}$ ed. São Paulo: Perspectiva, 1986.

ECO, Umberto. Obra aberta: forma e indeterminação nas poéticas contemporâneas. 10 a ed. Trad. Giovanni Cutolo. São Paulo: Perspectiva, 2015.

KAFKA, Franz. Metamorfose. Trad. Marcelo Backes. Porto Alegre: L\&PM, 2017 a. KAFKA, Franz. O Processo. Trad. Marcelo Backes. Porto Alegre: L\&PM, 2017b. PONDÉ, Luiz Felipe. Crítica e profecia: a filosofia da religião em Dostoiévski. São Paulo: Leya, 2013.

PROUST, Marcel. Em busca do tempo perdido. Vol. 1: No caminho de Swan. Trad. Mario Quintana. São Paulo: Globo, 2006.

\section{Trânsitos Interdisciplinares em Artes}

Bárbara Tavares dos Santos, Liliane Scarpin S. Storniolo, Renata Patricia da Silva (Organizadoras)

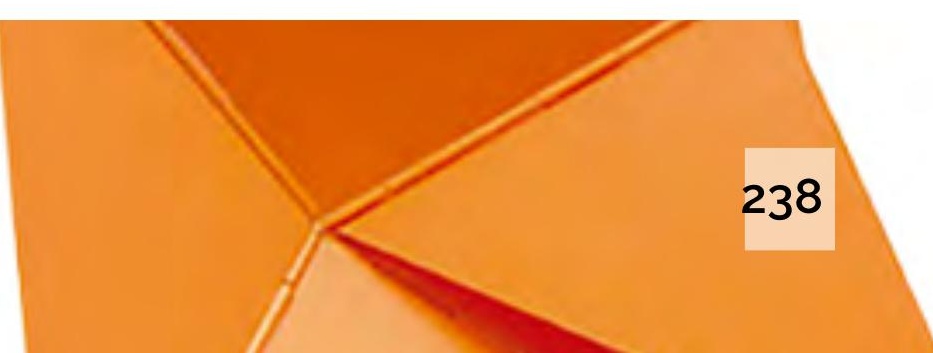


SANTOS, Maria Angélica Amâncio. A gratuidade do mundo e a maleabilidade do gênero literário em o Estrangeiro de Albert Camus. Belo Horizonte: Faculdade de Letras da UFMG, 2009. (Tese de doutorado).

SARTRE, Jean-Paul. Situações I: críticas literárias. Trad. Cristina Prado. São Paulo: Cosacnaify, 2005.
SARTRE, Jean-Paul. O existencialismo é um humanismo. Trad. João Batista Kreuch. Petrópolis: Vozes, 2014

SARTRE, Jean-Paul. A Náusea. Trad. Rita Braga. Rio de Janeiro: Nova Fronteira, 2015

\section{Trânsitos Interdisciplinares em Artes}

Bárbara Tavares dos Santos, Liliane Scarpin S. Storniolo, Renata Patricia da Silva (Organizadoras)

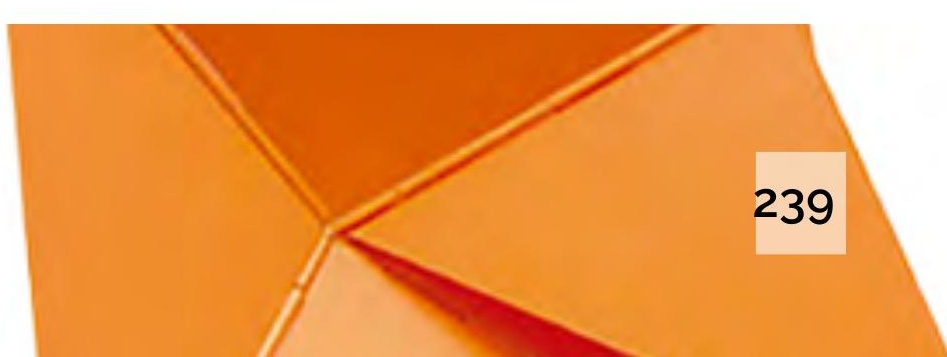

